RICARDO AZEVEDO BARRETO

\title{
UMA ANÁLISE INSTITUCIONAL DO DISCURSO EM GRUPO COM DENTISTAS: CENAS E POSIÇÕES
}

Tese apresentada ao Instituto de Psicologia da Universidade de São Paulo para a obtenção do título de Doutor em Psicologia.

Área de Concentração: Psicologia Escolar e do Desenvolvimento Humano

Orientadora: Profa. Dra. Marlene Guirado

São Paulo

2009 
AUTORIZO A REPRODUÇÃO E DIVULGAÇÃO TOTAL OU PARCIAL DESTE TRABALHO, POR QUALQỦER MEIO CONVENCIONAL OU ELETRÔNICO, PARA FINS DE ESTUDO E PESQUISA, DESDE QUE CITADA A FONTE.

Catalogação na publicação

Biblioteca Dante Moreira Leite

Instituto de Psicologia da Universidade de São Paulo

Barreto, Ricardo Azevedo.

Uma análise institucional do discurso em grupo com dentistas: cenas e posições / Ricardo Azevedo Barreto; orientadora Marlene Guirado. -- São Paulo, 2009.

$198 \mathrm{p}$.

Tese (Doutorado - Programa de Pós-Graduação em Psicologia. Área de Concentração: Psicologia Escolar e do Desenvolvimento Humano) - Instituto de Psicologia da Universidade de São Paulo.

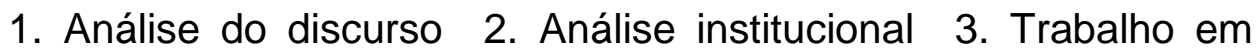
grupo 4. Odontologia I. Título. 
Nome: BARRETO, Ricardo Azevedo

Título: Uma análise institucional do discurso em grupo com dentistas:

cenas e posições

Tese apresentada ao Instituto de Psicologia da Universidade de São Paulo para a obtenção do título de Doutor.

Área de Concentração: Psicologia Escolar e do Desenvolvimento Humano

Aprovado em:

Banca Examinadora

Dr.

Instituição:

Assinatura:

Dr.

Instituição:

Assinatura:

Dr.

Instituição:

Assinatura:

Dr.

Instituição:

Assinatura:

Dr.

Instituição: Assinatura: 


\section{DEDICATÓRIA}

Com Deus, minha bússola, meu grande guia nas alegrias e adversidades, meu Pai maior em todos os passos e momentos da vida, hoje dedico este trabalho ao meu pão e vinho de cada dia:

A minha adorada esposa Mara e meus preciosos filhos Lara e Danilo, esteios seguros nesta estrada, participantes incondicionais, refrão de toda música de amor na minha existência. Vocês são meus tesouros... minhas orquídeas raras na plantação sagrada de meu cotidiano.

A meus queridos pais José Augusto e Ceiça por me ensinarem a ser humano e a ler a partitura da vida com tanta dedicação, sem a qual não iria em busca de meus sonhos. Sou sujeito de meu desejo, porque me amaram e permitiram "voar".

A meus sogros-pais Francisco e Augusta, também aos avós, Gervásio e Ester, pela ternura e sapiência.

A meus carinhosos irmãos e cunhados, bem como tios, sobrinhos, afilhados e demais familiares por me ajudarem com beleza em todas as horas e nos maiores naufrágios da vida.

A meus amigos de coração... 


\section{AGRADECIMENTOS}

À minha orientadora, querida professora e amiga, livre-docente, Dra. Marlene Guirado, por ser sempre inspiração afetiva e intelectual em meu caminhar. É uma instituição de saber. Agradeço-lhe muito por todos os ensinamentos e sua sensibilidade analítica, condição-mãe de produção do meu pensar. O método que criou, a Análise Institucional do Discurso, é uma estratégia apaixonante do conhecimento científico.

À Dra Marilene Proença e Dra. Marta Cristina Meirelles Ortiz, pela acolhida humana de minhas ideias e pelas contribuições valiosas no ensino e/ou exame de qualificação, bem como pelos exemplos de compromisso ético, institucional e político com a Psicologia.

À Dra. Maria Sandoval Schmidt e ao Dr. Rogério Lerner, por serem referências sólidas na construção de meu pensamento e na arte de ser professor com efeitos de afetividade.

Aos membros da Banca Examinadora de meu Doutorado, por sua presença, tão importante para mim. São pessoas por quem tenho grande admiração.

Às dentistas participantes desta pesquisa, competentes profissionais, pela singularidade especial de cada uma e o vínculo com a produção do conhecimento científico. Se vocês repensaram sobre suas práticas e se movimentaram nas relações com pacientes e acompanhantes na Odontologia, possibilitaram-me a reconstrução de meu lugar de analista de forma inesquecível.

À instituição de ensino, seus representantes e professores que me permitiram a oportunidade de realizar minha pesquisa de doutorado com seus pós-graduandos com tanta alegria.

A todos os amigos queridos do grupo de orientação da professora Dra. Marlene Guirado pelo grande suporte e afeto que me deram.

Aos professores do Instituto de Psicologia da Universidade de São Paulo com os quais tive a oportunidade de conviver. Com vocês, aprendi grandes lições de vida. Em especial, minha gratidão eterna à Dra. Lígia Assumpção Amaral (in memoriam). Aos funcionários desta Casa e de sua biblioteca, pelo acolhimento, carinho e doação, também agradeço.

À minha psicanalista Claire Pezzi, por ser travessia e doçura em minha existência. Sem a aventura da escuta de mim mesmo, não teria força para produzir a minha obra por causa das intempéries da vida. Minha gratidão por me reinventar na arte de sua companhia por meio da qual me reconheci como psicanalista, poeta e agora me vejo como doutor em Psicologia. 
Aos meus pacientes, pelos silêncios, choros, sorrisos, enigmas e palavras, bem como pela experiência de presenciar as metamorfoses do humano em um jardim de pétalas de lágrimas.

À Universidade Tiradentes, onde trabalho como professor no curso de Psicologia. A seriedade dessa instituição e a valorização do docente orgulham-me de fazer parte dessa grande família. Agradeço pelo apoio dado à minha capacitação docente e pela grande amizade de todos com quem nela convivo e a quem estimo, em especial à família Prof. Uchôa; também aos prezados Temisson e Cirino.

A meus alunos, pelo incentivo à formação continuada no exercício da Psicologia.

À Dra. Déborah Pimentel, grande amiga e ser humano ímpar, presidente do Círculo Brasileiro de Psicanálise. Indizível é nosso laço. Formamos parceria como editores da Revista Estudos de Psicanálise e nas estradas da vida. Sabe como é importante para mim e quanto a admiro pela inteligência, tenacidade e criatividade.

Às queridas e fraternas companheiras do Círculo Psicanalítico de Sergipe e todos com os quais tive contato nesse Lar: Cecília, Claire, Déborah, Edméa, Graça, Lídia e Patrícia, pelo afeto que nutro por cada uma de vocês, pelo privilégio de conviver com o brilhantismo profissional das "super poderosas", pelo leite quente e amor dedicado, pelo impossível de simbolizar.

A Vânia, da biblioteca da Odontologia da USP, pela ajuda e delicadeza de sempre no meu levantamento bibliográfico para a pesquisa.

Ao professor José Araújo Filho pela revisão do português com as regras novas da língua, bem como a Julian Lawley e Francislene Westwood pela revisão do inglês.

A Paulo, Renata, Luigi e Ana Giulia, minha família de Sampa, vínculo intenso que se escolhe com a alma. Obrigado pela casa com mel e por existirem em minha vida.

A Gustavo, Rafaela, Paulinho, Gabriel e Tiago, por serem jóias raras em meu coração, pétalas de uma mesma flor e reencontro familiar em São Paulo.

A Fátima e a Letícia, por me acompanharem e apoiarem tão de perto na trajetória Aracaju-São Paulo-Aracaju e na realização desta conquista.

Àqueles que, de alguma forma, com uma escuta, um olhar ou um gesto de altruísmo, contribuíram para esta jornada polifônica e polissêmica, com luz, sombreados e as condições de criação de cenas e posições para a realização deste sonho em anos nos quais vivências profundas e intensas tive nos planos científico e afetivo.

Como disse meu filho Danilo aos quatro anos de idade: "Papai, já estou terminando meu Doutorado." É vero! Nós todos: a querida mamãe, a amada primogênita, a boneca Lara, você "tão veloz" e papai, graças a Deus! 
A ordem do discurso

Ao invés de tomar a palavra, gostaria de ser envolvido por ela e levado bem além de todo começo possível.

Foucault 


\section{RESUMO}

BARRETO, R.A. Uma análise institucional do discurso em grupo com dentistas: cenas e posições. 2009. 198 f. Tese (Doutorado) - Instituto de Psicologia, Universidade de São Paulo, São Paulo, 2010.

Este estudo foi uma pesquisa-intervenção em instituição da Odontologia por meio de um grupo com dez dentistas durante seis encontros, de aproximadamente uma hora e meia cada um, sobre as práticas odontológicas e relações com pacientes e acompanhantes. Sua proposta foi a investigação dos efeitos de uma análise institucional do discurso, método que vem sendo desenvolvido por Marlene Guirado. Foi feita uma análise concreta, em ato e na dimensão grupal, no que se refere à mobilização nos posicionamentos discursivos dos participantes e ao acompanhamento de possíveis movimentos nas relações entre agentes institucionais e clientela. No texto da tese, do ponto de vista teórico, inicialmente trilhamos um percurso pela Odontologia, depreendendo um lugar para o dentista num breve histórico dessa profissão. Posteriormente, apresentamos interfaces existentes na literatura especializada entre Psicanálise, Psicologia e Odontologia, pensando sobre os rumos dessas aproximações interinstitucionais. Então, debruçamo-nos sobre contribuições conceituais e trabalhos acerca de grupo, relevantes para nossa temática do que delineamos como nosso fio condutor de análise as relações institucionais em grupo. Diferenciamo-nos de uma visão de entidade ou mentalidade grupal comum nos meios psicológicos e psicanalíticos. $\mathrm{O}$ escrito sobre método é esclarecedor de nossas ideias e seus delineamentos procedurais. Com base nas análises da análise em ato, pudemos perceber efeitos no imaginário e na micropolítica das relações na Odontologia na ordem institucional das cenas e posições no discurso. Defendemos a tese de que a Análise Institucional do Discurso é uma estratégia de pensamento rica para além das entrevistas, seu modo operativo usual, especialmente para o trabalho em grupo, como será reconhecido no tocante à temática que propusemos. Sugerimos ainda que tal método seja referência para novos estudos de intervenção nas áreas da Psicologia e Psicanálise, não apenas em grupo. A fertilidade de tal recurso se refere a articular, na ruptura do instituído, tais áreas do conhecimento mencionadas com outros aportes epistemológicos, como a Análise do Discurso Francesa, a Análise de Instituições Concretas e o pensamento de Foucault.

Palavras-chave: Análise do Discurso. Análise Institucional. Trabalho em grupo. Odontologia. 


\section{ABSTRACT}

BARRETO, R.A. An institutional discourse analysis in dentists' group: scenes and positions. 2009. $198 \mathrm{f}$. Thesis (doctoral) - Instituto de Psicologia, Universidade de São Paulo, São Paulo, 2010.

The present study was an interventional research within the Dentistry institution which involved a group of ten dentists, during six meetings of approximately one and a half hour each, about dental practices and the relationships with patients and their companions. The aim of the study was to investigate the effects of one institutional analysis of the discourse, a method which has been developed by Marlene Guirado. A concrete analysis was carried out both in action and in the group dimention, concerning the mobility of speech positions of the participants and about the observation of possible movements in the relationships between institutional agents and clientele. Within the thesis text, from a theoretical point of view, we started off by examining Dentistry itself, understanding the role of the dentist in a brief History of the aforementioned profession. Afterwards, we presented interfaces in the specialized literature concerning Psychoanalysis, Psychology and Dentistry, and we think about the trends of these interinstitutional approximations. That being the case, we focused on the conceptual contributions and studies concerning group, relevant to our theme and to what we drew as our main guideline for the analysis: the institutional relationships in group. We differ from a vision of group entity (or group mind) so common in the psychological and psychoanalytic fields. The writing about method is elucidative of our ideas and their procedural designs. Based on the analysis of the act analysis, it was possible for us to perceive effects in the imaginary and micropolitics of Dentistry relations in the institutional order of the discourse scenes and positions. We defend the thesis that the Institutional Discourse Analysis is a rich thinking strategy for beyond the interviews, its habitual operative style, to group work particularly as it will be recognized in the thematic proposed. We suggest, still, that such method be a reference for new interventional studies in both Psychology and Psychoanalysis fields, not just in a group. The fertility of this recourse concerns linking the aforementioned areas of knowledge with other epistemological bases such as the French Discourse Analysis, Concrete Institutional Analysis and Foucault's thoughts, overturning what is established.

Keywords: Discourse Analysis. Institutional Analysis. Group work. Dentistry. 


\section{SUMÁRIO}

1. INTRODUÇÃO

2. A INSTITUIÇÃO DA ODONTOLOGIA: A CONSTRUÇÃO DE UM LUGAR PARA O DENTISTA

3. PSICANÁLISE, PSICOLOGIA E ODONTOLOGIA: ALGUMAS CONSIDERAÇÕES NECESSÁRIAS 25

3.1. Sobre Psicanálise, oralidade e Odontologia ......................................................... 25

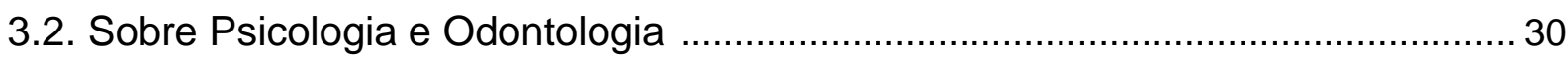

4. SOBRE GRUPO: DIMENSÕES CONCEITUAIS E ALGUMAS CONTRIBUIÇÕES DE TRABALHOS RELEVANTES PARA NOSSA TEMÁTICA 38

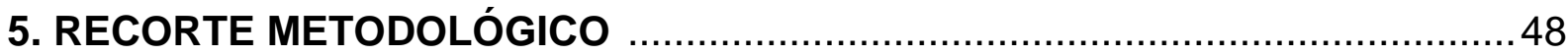

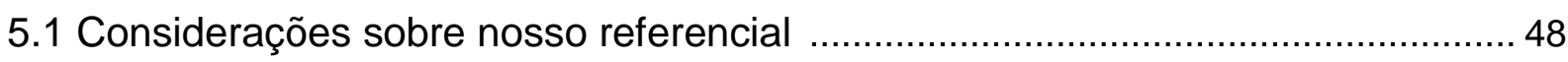

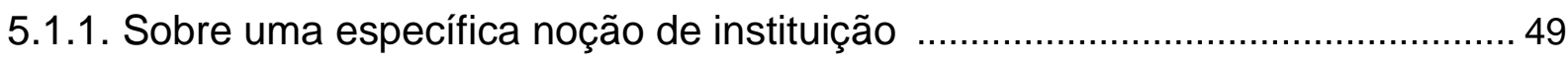

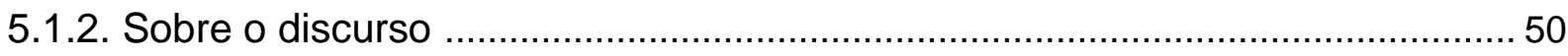

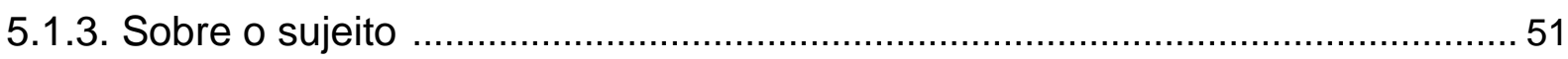

5.1.4. Sobre a Análise Institucional do Discurso ................................................... 51

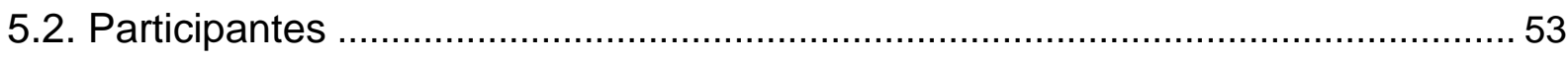

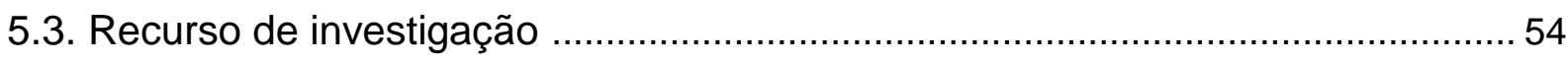

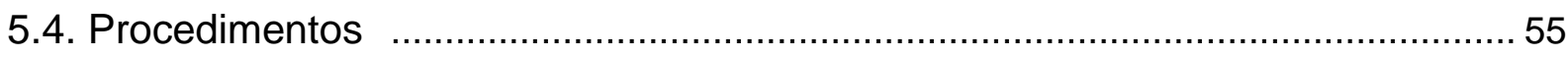

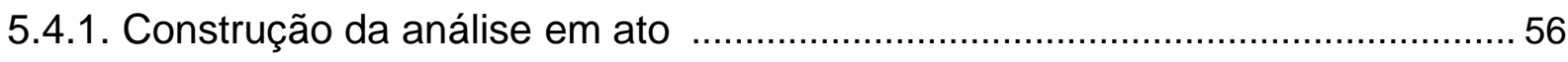

5.4.2. Procedimentos de análise da intervenção realizada ....................................... 60

6. AS ANÁLISES: CENAS E LUGARES NO DISCURSO DE DENTISTAS ACERCA

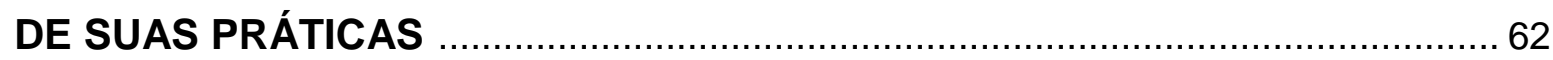

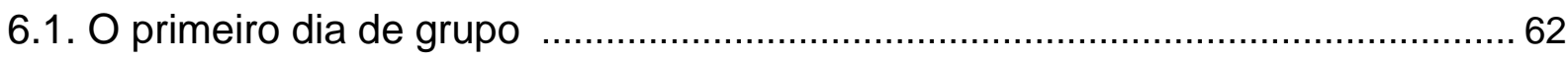

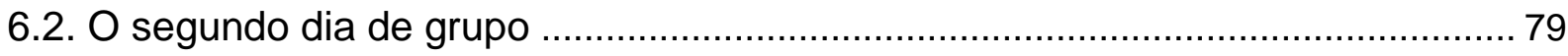

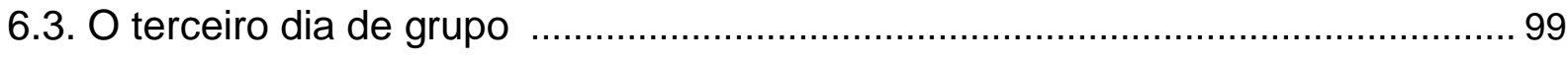

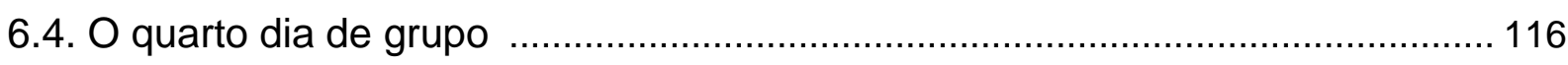

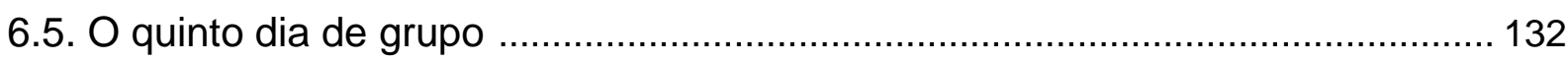


7. SOBRE O ATO DA ANÁLISE INSTITUCIONAL DO DISCURSO EM GRUPO COM DENTISTAS

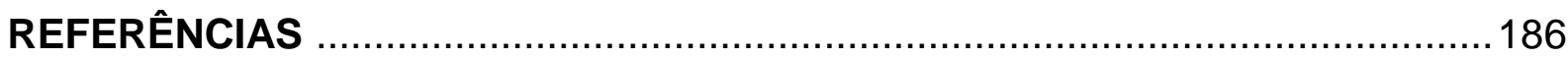

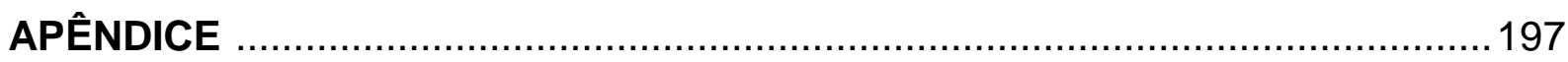




\section{INTRODUÇÃO}

Partimos neste estudo de um problema de pesquisa que localizamos com os seguintes contornos: pode ser produzida uma mobilização nos posicionamentos discursivos de profissionais em suas relações/práticas com pacientes e acompanhantes por meio de uma análise institucional em grupo com dentistas? Se sim, efeitos se depreenderam nessas relações, e quais foram, com a intervenção analítica realizada?

Nosso estudo se desenhou, portanto, como uma investigação dos efeitos discursivos no campo institucional das relações na Odontologia de uma intervenção em ato, em um grupo de dentistas, com base na Análise Institucional do Discurso, método de autoria de Guirado, que vem sendo construído por ela gradativamente (1986/2004, 1987/2004, 1995/2006, 2000, 2007, 2009).

Fundamentados na interlocutora supramencionada, que tem como matriz conceitual o pensamento do sociólogo Guilhon Albuquerque, podemos entender a Odontologia como uma instituição no seguinte contorno: "[...] conjunto de práticas, ou de relações sociais, que se repetem e se legitimam enquanto se repetem [...]" (GUIRADO, 1986/2004, p. 44)

De acordo com Guirado (2005), essas práticas são reconhecidas, pelos que as fazem, como "naturais", tendo que ser como são, o que marca o desconhecimento da relatividade ao contexto e do caráter instituído de tais relações. A naturalização do fazer é compreendida como efeito de reconhecimento/desconhecimento, isto é, atribui-se legitimidade aos procedimentos que se desenham nos dispositivos discursivos que os produzem.

Em nossa compreensão, os odontólogos podem ser pensados como agentes institucionais da Odontologia que estabelecem com os pacientes e acompanhantes determinado tipo de relações. Nossa pesquisa, por outro lado, também pode ser concebida como uma instituição discursiva com cenas e posições.

Delinearemos nossos objetivos de pesquisa: a) investigar posicionamentos discursivos de dentistas nas relações com pacientes, acompanhantes e com a Odontologia no exercício de sua profissão, bem como b) acompanhar os possíveis efeitos do trabalho de Análise Institucional do Discurso nessas relações. Anunciemos que não pensamos em grupo como uma entidade categórica a ser 
acompanhada por nossa perspectiva analítica, mas em relações institucionais grupais.

Algumas hipóteses foram aventadas a respeito dos efeitos produzidos por esta pesquisa: dentistas se implicariam de um outro modo nas relações na Odontologia, "questionando" a ordem instituída, bem como reconheceriam outras dimensões nessas relações. Além disso, implicações na correlação de forças nas posições exercidas na tríade profissional-paciente-acompanhante delineadas no discurso seriam passíveis de acontecimento.

Entendemos a Análise Institucional do Discurso em grupo por nós desenvolvida como uma ruptura por meio do pensar, pensar este que não identificamos com o da lógica cartesiana, mas engendra o que tem de desconhecimento/inconsciência em seu produzir.

Mas por que escolhemos estabelecer nossa pesquisa psicológica com profissionais em pós-graduação da Odontologia?

Antes de tudo, pensamos que pesquisar, a partir da perspectiva psi, outras profissões é importante, pois é uma possibilidade de conhecer e/ou mover o que se institui nestas áreas, assim como de produzir interfaces entre campos distintos do saber.

Percebemos há muito uma preocupação, ora mais ou menos explícita, com uma visão de saúde que cria interfaces entre especialidades, compõe equipes, contrapondo-se ao modelo médico, matizado pela perspectiva biológica.

Nogueira-Martins (2002) fala da importância de mudanças curriculares, intervenções psicopedagógicas, transformação na jornada de trabalho, grupos de discussão e reflexão, ao se referir à área de saúde. Pimentel (2005), ao retratar a saúde dos profissionais de saúde por intermédio de pesquisa científica na qual investigou diferentes categorias profissionais, tece algumas propostas específicas no campo da saúde, por exemplo: mais pesquisas, diminuição da carga horária nos treinamentos, políticas públicas de saúde e humanização da assistência, serviços especiais (de apoio e assistência em saúde), grupos Balint e psicoterapia. Com base também em Macedo, Nogueira-Martins e Nogueira-Martins (2008), podemos referirnos às políticas e aos programas de humanização em saúde.

Tal movimento, que vai ao sentido da superação do paradigma organicista, produz, além de uma visão mais crítica das práticas de saúde, um deslizamento do 
pensar e fazer o cotidiano no campo da saúde em que destacamos a relevância de olharmos mais os profissionais.

Em relação à Odontologia, é importante estudá-la, sobretudo a partir da Psicologia/Psicanálise, porque as relações entre essas áreas podem ser mais alinhavadas em termos de pesquisa acadêmica, principalmente no que tange a assuntos escassos na literatura especializada. Se o contato entre Psicologia e Odontologia é promissor, de acordo com Barreto (2003), esse campo amplo e fértil de contribuições psicológicas à Odontologia é pouco desbravado. Por outro lado, ouçamos:

Sucção do polegar, bruxismo, fobia ou trauma do atendimento odontológico, vivências emocionais dos pacientes com lábio leporino e de seus familiares, relação entre dentista e paciente são apenas algumas das situações que contornam a importância da Psicanálise para a Odontologia (BARRETO; GUIRADO, 2009, p. 147).

Consideramos ainda que percebemos que a maioria das publicações encontradas se situa não como pesquisas científicas, mas na dimensão de teoria aplicada em que Psicologia e Psicanálise oferecem seus conceitos e técnicas à Odontologia, o que será problematizado mais adiante em nosso texto. Pensamos ainda que ter como participantes dentistas em pós-graduação seria interessante, pois são profissionais graduados em busca de mais conhecimento e uma formação continuada.

E por que desenhamos nosso estudo como uma intervenção psicológica em grupo com base na Análise Institucional do Discurso?

Por várias razões. De modo geral, queríamos produzir rupturas no que se repete quanto à Psicologia e Psicanálise voltadas à Odontologia. Poucos trabalhos de pesquisa com intervenção em grupo com dentistas foram encontrados. Os mesmos não tomaram uma perspectiva analítica institucional discursiva na relação do pesquisador com seu estudo.

A Análise Institucional do Discurso, herdeira da Psicanálise, por definir seu objeto como as relações institucionais, possibilita-nos nuanças inovadoras à pesquisa em relação aos trabalhos psicológicos e psicanalíticos concernentes à área de Odontologia, bem como diverge de um modelo clínico e permite que pensemos os grupos como instituições no ato de sua construção e desenvolvimento; por isso foi o método escolhido. 
Pensamos que a singularidade e a importância de nosso trabalho têm também relação com nosso reconhecimento dele como um recorte muito específico no campo epistêmico, distanciado de proposições de leis gerais, tentativas de abarcar o todo e de aplicações imediatas da Psicologia/Psicanálise em um outro campo do saber. Nossa perspectiva de análise institucional do discurso se afasta do teoricismo, da "visão global" e do utilitarismo na Psicologia. Em nosso ponto de vista, produzimos ainda discursos/instituições por meio de nosso estudo. É, portanto, em uma relação de interioridade com o dizer e o fazer institucional que nosso trabalho se constitui.

Também consideramos que nossa investigação é a primeira pesquisa acadêmica que tem $\circ$ mencionado referencial metodológico para o acompanhamento de efeitos de uma intervenção em grupo, problematizando as potencialidades do método que tem como modus operandi mais habitual as entrevistas.

Não estamos falando de uma postura política no espectro de possibilidades de mover as correlações de forças na produção do saber, na construção de nosso estudo, o que é condizente com a estratégia de pensamento adotada?

Argumentos ainda se referem ao que se atém à experiência acadêmicocientífica do pesquisador. Como autor, professor, pesquisador, inclusive no mestrado (BARRETO, 1999), de Psicologia nas interfaces com a temática da Odontologia, foi sentindo a importância de realizar um estudo dos efeitos de uma intervenção psicológica na Odontologia que a tocasse e a questionasse como instituição.

Construímos, por conseguinte, esta pesquisa qualitativa em que consideramos fundamental o estabelecimento de vínculo que permitisse uma maior aproximação entre pesquisador e participantes. Não entendemos, contudo, proximidade como indiferenciação entre os lugares desses atores da pesquisa. O dizer de Guirado (2005) é esclarecedor, quando mostra atenção na cena enunciativa ao lugar do analista com suas expectativas e também ao delegado transferencialmente a ele pela clientela.

Salientamos também que nosso estudo, que passou por mudanças no decorrer de nosso trajeto no Doutorado, insere-se na linha de pesquisa do Departamento de Psicologia da Aprendizagem, do Desenvolvimento e da Personalidade (PSA), do Instituto de Psicologia da Universidade de São Paulo (IPUSP), chamada "Instituições 
educacionais e formação do indivíduo", pois tem como participantes dentistas em pós-graduação em instituição de ensino da Odontologia.

Em suma, a tese a ser defendida neste trabalho é a de que a Análise Institucional do Discurso é um método fértil para o campo de intervenção psicológica em grupo, o que procuraremos demonstrar no decorrer de nosso texto acerca da pesquisa realizada que emergiu de uma proposição que articulamos no terreno das relações entre Psicologia/Psicanálise e Odontologia, relevante do ponto de vista científico-acadêmico temático e metodológico.

Tal construção científica é valiosa, já que a Análise Institucional do Discurso articula a Psicanálise com outros aportes epistemológicos, como a Análise das Instituições Concretas, a Análise de Discurso Francesa e as contribuições de Michel Foucault, sendo uma forma inovadora de pensar a partir da Psicologia e Psicanálise.

Antecipemos que, a partir de então, passaremos a trilhar caminhos por capítulos teóricos que problematizam a instituição da Odontologia e de um lugar para o dentista; o "estado da arte" do campo interinstitucional da Psicanálise, Psicologia e Odontologia, bem como algumas contribuições sobre o trabalho psicológico em grupo e, mais especificamente, com profissionais de saúde e dentistas, ou na Odontologia. 


\section{A INSTITUIÇÃO DA ODONTOLOGIA: A CONSTRUÇÃO DE UM LUGAR PARA O DENTISTA}

Pretendemos apresentar um delineamento da trajetória da Odontologia em relação aos seus rumos como profissão. Partiremos das práticas odontológicas précientíficas à constituição da Odontologia como ciência para, então, contemplarmos alguns dos contornos que têm sido estabelecidos à área na contemporaneidade, debruçando-nos com mais especificidade no tocante ao contexto brasileiro.

A base para tais considerações são estudos que nos permitem tecer um breve histórico/retrato da área. No capítulo sobre as análises dos discursos em grupo, observaremos a recorrência de vários aspectos, aqui inventariados pelos autores consultados. Em ocasião oportuna, faremos a discussão de tal confluência.

"O cirurgião-dentista (CD) ou odontólogo é uma pessoa graduada em Odontologia por uma instituição de nível universitário após um curso específico ou não de duração variável conforme o país [...]" (PINTO, 2008, p. 320)

Entretanto, até a Odontologia tornar-se ciência no mundo e um lugar para o dentista desenhar-se com melhor nitidez, não sem exceções e variações culturais, um longo caminho foi percorrido em que durante muito tempo predominava uma perspectiva mágico-religiosa e mutiladora/extracionista concernente às práticas odontológicas; o lugar do profissional era de "tiradentes".

Wynbrandt (1998) comenta sobre a obscuridade das origens do que atualmente se conhece como Odontologia. Menciona que ela esteve nas mãos de praticantes ineptos, e, tradicionalmente, os dentes tinham importância na magia e eram os órgãos corporais mais comumente mutilados. Também relata que as dores de dente eram atribuídas a demônios, vermes ou fluidos, e as terapias prescritas eram brutais.

Figlioli (2001) localiza o nascimento da Arte Dentária, delineada como tipicamente instintiva, na Pré-História, com as primeiras dores de dente. Acompanhando Ring (1998), nós a percebemos de uma maneira ampla, abrangendo diferentes povos e épocas em que reconhecemos particularidades referentes à saúde dental, aos conhecimentos e às práticas odontológicas. Em alguns contextos, os dentes aparecem relacionados a adorno, associados a finalidades religiosas ou práticas mágicas. 
Podemos perceber também que as fronteiras entre Medicina e Odontologia não eram sempre bem demarcadas. Uma indiscriminação entre essas áreas é visível, o que nos parece importante do ponto de vista de uma análise da construção de um lugar para o dentista e suas práticas.

Não se encontra nem uma palavra dedicada aos dentistas em latim antigo,
pois a Odontologia não existia entre os romanos como profissão separada,
e os médicos romanos não diferenciavam entre as enfermidades que
afetavam a boca e os dentes, e as que interessavam a outras partes do
corpo [...] (RING, 1998, p. 46).

Aliás, sabemos que, ainda hoje, a independência da Odontologia em relação à Medicina traz variantes culturais, ou seja, em termos espaciais/temporais, a posição do profissional e das atividades da Odontologia não é uníssona, mas plural.

Entre as diversas dimensões depreendidas por nós na cena em que Ring (1998) fala da história da Odontologia, destacamos algumas:

- O dentista surgiu de vários praticantes que realizavam os serviços odontológicos, como, por exemplo, os barbeiros, os cirurgiões e os médicos.

- O século XVIII trouxe transformações profundas à Odontologia a partir das descobertas científicas do século que o antecedeu. Fauchard, na França, é referência para a Odontologia moderna, pioneiro e fundador da ciência odontológica. Foi ele quem cunhou tal expressão: "cirurgião-dentista".

- Mesmo tendo a França sido o berço da Odontologia moderna, posteriormente a liderança foi para os Estados Unidos.

- Com o tempo, as mulheres foram inserindo-se na Odontologia, bem como surgiram mudanças diversas, entre elas no âmbito da regulamentação da área.

- No século XX, emergiram transformações no equipamento dental, avanços no ensino, na técnica e na prática, tendência no sentido das especializações, proliferação de publicações, movimento em prol da higiene, entre outros aspectos. No decorrer da década de 1950, apareceu na América o campo da Odontologia Pública. As décadas posteriores à Segunda Guerra Mundial acompanharam mudanças. A assistência odontológica tornou-se acessível nos Estados Unidos e na Europa. No primeiro, ocorreu um aumento de práticas grupais e clínicas. A Odontologia não se identificava com o exercício individual em consultórios privados no pós-guerra; também surgiu a difusão do "pagamento através de terceiros", usualmente grupos seguradores. 
Pensando em marcos no campo do ensino da Odontologia, de acordo com Figueiredo et al. (2007), pelo que se sabe, foi em 1839, em Baltimore, nos Estados Unidos, que foi criado o primeiro curso para a formação específica de dentistas: College of Dental Surgery.

Conforme percebemos, houve um longo caminho até a Odontologia tornar-se instituição científica formadora no mundo, e o dentista possuir um lugar profissionalizado em diferenciação do ocupado por uma mistura de práticos. Em contrapartida, sabemos que, na atualidade, a experiência odontológica leiga sobrevive, antagonizando com as atividades reconhecidas em sua ciência na Odontologia.

Como vemos, então, os delineamentos dos contatos entre dentistas e clientela no mundo de hoje? A posição do profissional na Odontologia contemporânea é ambígua? O que seria possível mobilizarmos no campo institucional da Ciência Dentária em termos de relações/práticas sociais? São algumas das questões que nos parecem importantes a um analista institucional do discurso.

Neste momento, apresentaremos contribuições que nos possibilitam refletir acerca na Odontologia brasileira em busca de "pistas" para nossa análise desta área como instituição.

Com base nos ensinamentos de Furtado (2007) a respeito da história da Odontologia no Brasil, podemos pensá-la desde o período colonial. Naquele momento histórico, não existia um profissional que se dedicasse ao cuidado exclusivo dos dentes.

Percebemos que os dentes passam a ser associados, gradativamente, a uma área mais bem desenhada em sua especificidade, a Odontologia. Quanto as práticas odontológicas do período colonial no Brasil são distintas das atuais, em que há uma posição para o dentista em diferenciação de um emaranhado de praticantes, instituindo a área?!

Focando na atualidade, podemos fazer interlocução com Figueiredo et al. (2007), que configuram como espetacular o percurso da Odontologia no século XX. Reconhecem resultados que impressionam, visíveis em sorrisos alinhados, dentes brancos e boa articulação, simbolizando bem-estar e beleza. Também percebem a desigualdade social no país em que a ausência de serviços públicos com intervenção de qualidade, associada à baixa renda da maioria da população delineiam, inúmeras vezes, como única possibilidade a extração dentária. 
Nossos interlocutores falam que houve ampliação do campo de ação da Odontologia: a incorporação no atendimento da boca, não apenas os dentes. A cárie, por outro lado, passou a ser compreendida e tratada, levando-se em conta a multicausalidade, considerando-se fatores sociais, políticos e econômicos. Também fazem menção quanto à formação na área. A Odontologia foi percebida não somente como tratamento individual, mas envolvendo a saúde pública e a saúde do paciente como um todo.

Referem-se ainda a transformações a partir de inovações tecnológicas, novidades nos materiais e realce à estética. A aceitação das resinas compostas é percebida na perspectiva dos grandes avanços.

No tocante ao ensino de Odontologia no Brasil, enfatizemos que Figueiredo et al. (2007) mencionam que foi instituído oficialmente em 1884 em vinculação com as faculdades de Medicina do Rio de Janeiro e da Bahia. Também comentam que mudanças estruturais dos cursos de Odontologia se relacionam ao desenvolvimento do conhecimento na área.

Outra dimensão também muito importante da história da Odontologia é trazida por Carvalho (2001, p. 54):

Desde a regulamentação profissional no 1314 , de 17/1/1951, estalelecia-se que o exercício da profissão só seria permitido aos que se achassem habilitados por título obtido em Escola de Odontologia oficial ou legalmente reconhecida [...]

Quanto à pós-graduação, Figueiredo et al. (2007) comentam que, ao término da década de 1960, apareceram os dois primeiros cursos lato sensu no Brasil, na Universidade de São Paulo e na Universidade Federal do Rio de Janeiro. A partir dos anos 1980, os autores dizem que foi percebida a necessidade de ser complementada a formação do dentista com a demanda por especializações. Salientam ainda que é relativamente recente a evolução no Brasil do ensino de Odontologia em padrões de excelência internacional com reconhecimento mundial e que existem tanto uma oferta de dentistas qualificados no mercado, quanto uma tendência ao crescimento do número de especialistas, mestres e doutores. Outra dimensão que contemplam é que, com a criação do Sistema Único de Saúde (SUS), a Odontologia também iniciou a trilha de um novo caminho para a superação da desigualdade com a qual há muito convivemos.

Podemos perceber que a Odontologia, há algum tempo, se constituiu no Brasil uma ciência bem reconhecida, como também um curso de nível superior específico 
(graduação) com muitos requisitos quanto às competências e habilidades a serem desenvolvidas em quem almeja ser cirurgião-dentista, profissional capacitado, entre outras dimensões, a depender das particularidades do trabalho realizado, ao conhecimento e às práticas de saúde bucal, algumas vezes até pós-graduado em algum ramo da Odontologia.

Então, um lugar para o dentista atual foi configurando-se gradativamente. Houve épocas em que predominou uma concepção de saúde bucal extracionista. Nos anos 1970, houve investimento em restaurações. Posteriormente, o foco passou a ser a prevenção. Para muitos odontólogos, no século XXI, ultrapassar-se-á a questão da prevenção (FERREIRA, 1997).

Nas palavras de Figueiredo et al. (2007, p. 161), acompanhamos as mobilizações ao século XX:

Trilhou-se um caminho em que a Odontologia passou de mutiladora a curativa, evoluindo para uma prática cada vez mais preventiva, alcançando, já no fim do século, uma abordagem voltada para a promoção da saúde bucal integrada à busca da qualidade de vida [...]

Weyne e Harari (2006, p. 3) chamam atenção por outro lado:

A constatação de que uma expressiva massa dos novos conhecimentos ainda não permeou os currículos e, portanto, não faz parte do arsenal de recursos clínicos da odontologia, explica por que uma grande parcela dos dentistas ainda não se mostra capaz de diagnosticar e controlar os verdadeiros fatores etiológicos da doença cárie (e periodontal). Sem dúvida, essa é a razão pela qual a doença cárie e as suas sequelas ainda representam a principal causa de perdas dentárias, em qualquer faixa etária $[\ldots]$

Percebemos que mobilizações têm ocorrido na instituição da Odontologia e do papel do cirurgião-dentista, embora ainda exista paradoxalmente o ranço de algumas estereotipias e conservadorismos nas práticas odontológicas. Pensando na posição do odontólogo brasileiro, é legítimo que consideremos que o Conselho Federal de Odontologia (CFO), em seu Código de Ética Odontológica (2006), estabelece, entre outros aspectos, os direitos e deveres fundamentais ao profissional.

O Conselho Regional de Odontologia de Sergipe (CRO-SE), por sua vez, apresenta uma listagem de especialidades que integram o exercício profissional da área. São citadas:

Cirurgia e Traumatologia Buco-Maxilo-Faciais, Dentística Restauradora, Disfunção Têmporo-Mandibular e Dor Orofacial, Endodontia, Estomatologia, Radiologia Odontológica e Imaginologia, Implantodontia, Odontologia Legal, Odontologia do Trabalho, Odontologia para Pacientes com Necessidades Especiais, Odontogeriatria, Odontopediatria, Ortodontia, Ortopedia 
Funcional dos Maxilares, Patologia Bucal, Periodontia, Prótese BucoMaxilo-Facial, Prótese Dentária e Saúde Coletiva (2007, p. 58).

llustremos a inovação na Ciência Dentária com a Odontologia para bebês, ramificação jovem da Odontopediatria. De acordo com Walter, Ferelle e Issao (1996), nessa área, é importante o trabalho acerca do conceito de risco de cárie, inclusive para quem não é portador de doença, com o objetivo de intervenção anteriormente a qualquer ação direta relacionada ao bebê. Daí a atenção aos pais que, por meio da educação, deverão ser conscientizados. Sendo assim, a Odontologia para bebês é uma prática precoce com os pais participando, ao contrário do que constitui a Odontologia Convencional. Educação para a saúde, antes do surgimento dos dentes e da doença, configura-se como objetivo maior da Odontologia para bebês em que há referência a trabalho com atenção voltada à gestante e a seu filho.

De modo geral, percebemos, portanto, no cenário atual da Odontologia brasileira, uma diversidade de práticas. Se, por um lado, reconhecemos o grande avanço científico, aliado às conquistas da tecnologia e à consolidação do fazer nas especialidades odontológicas, por outro lado, muitos seres humanos ficam à margem dos cuidados necessários. Neste panorama, são diversas as ações possíveis da Odontologia: atividades de maior requinte estético; cotidiano de uma clínica popular; trabalhos em consultórios, hospitais, unidades de saúde, escolas, comunidades; práticas privadas e públicas, nas capitais e no interior; das perspectivas mais conservadoras às mais inovadoras do pensar e fazer a Odontologia mais ou menos afastados do ideário neoliberal.

$\mathrm{Na}$ instituição da Odontologia brasileira contemporânea, não podemos esquecer sequer os múltiplos atores que a constituem: além dos odontólogos, os técnicos em higiene dental (THDs), os atendentes de consultório dentário (ACDs), os leigos praticantes e a própria clientela, entre outros. Não negligenciemos, inclusive, aqueles que, da extraterritorialidade da Odontologia, diversos profissionais, como os psicólogos e médicos, por exemplo, tecem contato com essa área do conhecimento.

Consideremos aqui que os debates da Saúde Coletiva nos parecem enriquecer a reflexão sobre o lugar possível ao dentista e suas relações com sua populaçãoalvo. A Saúde Bucal Coletiva parece significar uma ruptura institucional no espectro das práticas na Odontologia.

[...] A Odontologia é o território do cirurgião-dentista. Não se fará a mesma afirmação para a saúde bucal, pois, nesse território, consequentemente, 
teriam que emergir não apenas outros personagens com funções auxiliares, mas antes e radicalmente a figura do paciente, isto é, do usuário [...] (BOTAZZO, 2003, p. 23).

Pinto (2008) refere-se à busca da Saúde Coletiva de uma abordagem mais social no tocante às necessidades de atendimento. Relaciona a resolução de problemáticas de saúde bucal a ações executadas pela Odontologia, mas também enfatiza as variáveis extraodontológicas. Comenta ainda:

A Odontologia, por sua forte tradição liberal, é uma profissão bastante conservadora em termos de princípios, de onde resulta um largo domínio do modelo clássico ou tradicional na maioria dos países [...] (p. 322).

No Brasil, onde existe pouco investimento em políticas públicas que propiciem qualidade de vida e promovam saúde, sobretudo em segmentos menos favorecidos, a organização dos serviços no campo da saúde não reverte esse quadro social. Pensar sobre a saúde, portanto, é ressaltado na perspectiva da inclusão social, levando-se em conta ciência e tecnologia como instrumentos para por em cena elementos facilitadores (WERNECK; FERREIRA, 2008).

Externamente à interlocução da Saúde Coletiva, Amaral e Barreto (1998) pensam também na relação entre Odontologia e tecnologia. Problematizam-na, propondo uma subversão da lógica de adaptação da clientela à técnica para uma oposta em que os recursos técnicos se adequariam às necessidades dos pacientes.

Pinto (2008, p. 5), discorrendo sobre a Saúde Bucal Coletiva, alerta:

Agir de forma isolada, fechando-se às relações e influências das demais ciências ou deixando de participar das lutas políticas que movem as sociedades humanas, é o caminho mais rápido para o insucesso de uma política de saúde bucal, por mais bem elaborada em termos técnicos que esta seja.

A Saúde Coletiva configura-se como movimento social. O objeto da Saúde Coletiva que se desenha interdisciplinar seria o homem e sua realidade. Seus discursos referem-se à vida humana (BOTAZZO, 2003).

Estamos, portanto, entre outros aspectos, pensando teoricamente no território das políticas públicas e não reduzindo a Odontologia brasileira a um projeto liberal sem participação das instâncias representativas da população.

Esclarece Roncalli (2003) sobre os serviços de saúde no Brasil:

O atual modelo de prestação de serviços de saúde do Brasil, corporificado no Sistema Único de Saúde (SUS), é resultado de um processo histórico de lutas do movimento sanitário brasileiro, intensificado a partir das décadas de 1970 e 1980 em consonância com as lutas pelo processo de redemocratização da sociedade brasileira (p. 29).

De fato, o SUS corre na contramão da tendência dos países da America Latina em geral e do Brasil em particular, como uma política de saúde com 
base nos preceitos da universalidade e da equidade, os quais são opostos à lógica neoliberal no que diz respeito à ação do Estado e ao estabelecimento de políticas sociais (p. 39).

Nosso interlocutor comenta acerca da introdução do Programa Saúde da Família (PSF) pelo Ministério da Saúde no Brasil em 1994, como proposta inserida na vigência do Sistema Único de Saúde (SUS), no que deixa transparecer ambiguidades.

Botazzo (2003) refere-se à controvérsia acerca da inclusão dos dentistas nas equipes do Programa Saúde da Família (PSF). Dias (2006) complementa que, para melhorar indicadores de Epidemiologia e elevar o acesso aos serviços voltados à Saúde Bucal, houve a inclusão de tal prática em 2000 no PSF, que já estava anteriormente em vigência. O Programa Brasil Sorridente, por sua vez, é lançado em 2004 no Ceará, representando a primeira iniciativa de amplo alcance do Ministério da Saúde para ações de Saúde Bucal.

Portanto, se a Odontologia como prática neoliberal foi se constituindo e oferecendo seus serviços a um segmento economicamente favorecido da população brasileira, precisamos problematizar a inserção tardia e insuficiente dos dentistas nas políticas públicas de saúde, o que encontramos também com outros profissionais. Além disso, não desconsideremos o número relevante de clínicas populares com serviço odontológico de baixa qualidade reservadas a muitos brasileiros.

Martins, Carvalhais e Drumond (2007) comentam ainda que o século XXI emerge trazendo uma revolução no conhecimento, em que a ciência é protagonista, e valorizam as questões éticas e humanísticas, como contraponto em um mercado que não se determina mais pelas formas do capital clássicas, mas pela preponderância da informação rápida e maciça, bem como pela produção contínua de conhecimento.

Sobre a Odontologia, nossos interlocutores também dizem:

A prática odontológica que tinha até a metade do século anterior sua ênfase no tratamento dos dentes e evoluiu para o tratamento da boca volta-se agora para o cuidado com as pessoas. Deixamos de tratar de dentes para cuidar de gente! (2007, p. 194)

Enfatizam (2007) a vinculação da Odontologia com questões sociais e ressaltam a compreensão dos ciclos vitais. Refere-se a uma prática ampla com cuidados do bebê ao idoso, ultrapassando a clínica, em interação com as ciências humanas, sociais e comportamentais, e em cenários novos para a atuação: 
domicílio, creche, escola e meio ambiente. Configuram uma Odontologia centrada na promoção de saúde, requerendo a integração em equipe, associada à Bioética e ao mundo virtual com reflexos no ensino odontológico.

Por fim, cabem-nos muitas indagações quanto à instituição da Odontologia: a formação dos dentistas superou o paradigma tradicional na Odontologia brasileira? Quanto os profissionais contribuem na área às conquistas quanto a políticas públicas de saúde? Poderemos e quando falar de uma Odontologia da promoção da saúde não restrita a determinados extratos sociais de nosso país? Quanto as políticas públicas brasileiras precisam ser renovadas com uma maior inclusão de práticas da Saúde Bucal Coletiva? Esses são questionamentos que ultrapassam a intenção de nosso trabalho, mas problematizam a complexidade da instituição Odontologia.

Parece-nos que o campo da Odontologia é constituído por ambiguidades. No passado, havia uma sobreposição de profissionais na produção das práticas odontológicas, sem um lugar bem demarcado ao dentista. Os odontólogos brasileiros hoje não teriam o desenho de vários posicionamentos, definidos agora com base em recortes distintos de objetos e métodos de trabalho, mesmo que identificados pela expressão "cirurgião-dentista"? Um profissional da área que trabalha em consultório privado poderia ser visto no mesmo lugar discursivo-social de um odontólogo sanitarista? Como vemos, muitas nuanças precisam ser consideradas na análise institucional da Odontologia. 


\section{PSICANÁLISE, PSICOLOGIA E ODONTOLOGIA: ALGUMAS CONSIDERAÇÕES NECESSÁRIAS}

Se, no capítulo anterior, pensamos na Odontologia como instituição, no presente, trilhamos o "estado da arte" do campo interinstitucional dos contatos da Psicanálise, Psicologia e Odontologia em temáticas relevantes para nosso estudo. Uma ressalva faz-se necessária em princípio: apresentaremos o que se enuncia no terreno por psicanalistas, psicólogos, mas também por outros profissionais, como, por exemplo, os odontólogos.

Sabemos que diversos ramos do saber, como a Psicossomática e as Neurociências, poderiam ser consideradas em suas especificidades em nossas interlocuções, o que não fizemos. Delimitações ocorreram em nosso percurso. Como nosso trabalho é com a Análise Institucional do Discurso (AID), que tem uma fronteira com a Psicanálise, esta área foi privilegiada especialmente. Por outro lado, por ser a AID um método psicológico, mostramos algumas relações entre Psicologia e Odontologia.

Enfatizamos também que não temos a intenção de exaurir 0 assunto a desbravar, e sim de fazer um acompanhamento teórico em análise institucional de alguns discursos na literatura especializada. Marquemos ainda que trabalhos $p s i \mathrm{em}$ grupo na Odontologia vão ser discutidos no próximo capítulo em função do desenho discursivo que criamos.

\subsection{Sobre Psicanálise, oralidade e Odontologia}

Inicialmente, procuramos acompanhar o lugar da boca e da dentição em alguns posicionamentos que tomam uma perspectiva da Psicanálise, área psi com construções teóricas importantes sobre a oralidade. Destaquemos que, neste eixo, não há, na cena discursiva, diretamente a Odontologia por parte do que apresentaremos com base em nossos interlocutores. Numa segunda corrente de ideias, nós nos endereçamos a considerações da Psicanálise em que há uma 
presença clara de um lugar para seus contatos com a Odontologia e sua reflexão sobre as relações nesta área de atuação.

Reportemo-nos, em princípio, ao pai da Psicanálise. Freud não desenvolve um trabalho específico no terreno da Odontologia, mas se refere desde muito cedo em sua obra (1905/1980) a uma sexualidade infantil. Entre os aspectos que comenta, delineia um lugar para a sexualidade oral.

Sabemos que, na perspectiva freudiana, o desenvolvimento psicossexual é crivo para a compreensão do ser humano. A fase oral é a primeira de uma série e marca o contato do bebê com o mundo ao nascer. Podemos falar psicanaliticamente que o seio não é apenas provedor de alimento, necessário à sobrevivência, mas é fonte de prazer. Com os dentes, a atividade psíquica se incrementa. Como há possibilidades de idas e vindas no desenvolvimento, podemos falar de pontos de fixação e regressão à fase oral e dimensões da oralidade em algumas psicopatologias.

De acordo com Abraham (1970), existe uma diferenciação na fase oral. No primeiro nível, a libido liga-se ao sugar, e o ato é de incorporação. A criança não distingue entre o seu eu e o mundo externo. Não há sentimentos de ódio e amor. Não existe ainda a ambivalência. No segundo nível, sádico-oral, o sugar é trocado pelo morder. Há predominância de impulsos de canibalismo. A criança, ao se atrair por um objeto, tem a tendência de destruí-lo. Há o desenvolvimento da ambivalência.

Em uma perspectiva kleiniana, podemos falar, com base em Kristeva (2002), que as relações de objeto ocorrem desde o início da existência. O objeto primário é o seio da mãe. Em princípio, para o bebê, existe uma divisão entre a experiência do seio (diríamos: ou mamada) sentido como bom, que gratifica, e o seio sentido como ruim, que frustra. Há, no início, uma separação entre amor e ódio com situações ansiógenas e defesas de uma posição chamada de esquizoparanoide. Com o tempo, há uma integração, por meio de uma noção de objeto total, bem como uma dinâmica psíquica mais madura em que há a descoberta pelo bebê de sua realidade psíquica própria. É a posição depressiva. Podemos ainda mencionar que essas posições são intercambiáveis no decorrer da vida.

As contribuições acerca da oralidade e os simbolismos inconscientes da boca e dos dentes são comuns entre os psicanalistas. Saimovici e Saimovici (1972) relatam, por exemplo, fantasias de vagina dentada, uma relação simbólica entre 
dente e pênis, bem como o significado da dentição e dos dentes nas obras de diferentes psicanalistas.

Giron (1988), ao falar do simbolismo onírico dos dentes, menciona que, na perspectiva freudiana, a "queda do dente" teria significado de castração ou desta como castigo em função da masturbação. Em sonhos de mulheres, o dente teria 0 significado de nascimento. A respeito da primeira dentição, esta seria associada à separação entre prazer e função alimentar de autoconservação, bem como ao surgimento de impulsos de sadismo na fase oral. Sobre a segunda dentição, ela se instalaria em conexão com o desenvolvimento sexual.

Aberastury (1992) menciona sintomas comuns ao lactente no primeiro ano de vida (segunda metade deste) que recebeu o rótulo de transtornos de dentição. A autora (1996) refere-se a alterações no sono, entre outros aspectos emocionais relacionados à dentição. Para ela, o nascimento dos dentes de um bebê se associa ao aumento das tendências agressivas. Também relaciona dentes a uma visão de genitalidade.

Barreto (2002a) refere-se à perspectiva freudiana de desenvolvimento psicossexual, retomando explicações de Davidoff, Hall e Lindzey, Fadiman e Frager. É desenhado que, na fase oral, em torno do primeiro ano de existência, há obtenção de prazer por meio da cavidade oral e dos lábios. A alimentação, por intermédio do seio e da mamadeira, cumpre não apenas uma função de sobrevivência, mas é provedora de conforto e carinho. Com o surgimento dos dentes, incluem-se morder e mastigar, atos através dos quais haveria liberação da agressividade. Há referência ainda ao desmame como desafio e a traços orais em adultos, como dependência, comer excessivo e fumar.

Conforme percebemos, a Psicanálise contorna uma posição especial à boca e aos dentes, entendendo-os sob o crivo de noções como fase oral, inconsciente e sexualidade nas quais se incluem ideias sobre genitalidade e castração. Apesar de sabermos das diferenças teóricas entre os autores da área, e não nos debruçarmos sobre esses meandros, o que ressaltamos é que, no discurso da Psicanálise, há a legitimação de um lugar especial para a boca e os dentes, para a oralidade, entendida como instauradora do contato do bebê que nasce com o mundo, fundamental para a constituição do psiquismo.

Pensamos ainda que este lugar discursivo para a oralidade tem desdobramentos instigantes ao ser reposicionado na Odontologia, havendo uma 
compreensão dos acontecimentos odontológicos com base em noções psicanalíticas clássicas.

Neste momento, mencionaremos algumas contribuições pelo ângulo da Psicanálise no que tange a um lugar discursivo para a Odontologia e as relações nesta área de atuação. Para tal interlocução, alguns autores supracitados serão reinseridos na cena que se constitui em discurso.

Nas fronteiras da América Latina, mais especificamente na Argentina, ressaltamos a inventividade de Aberastury. No entanto, não é só com esta autora que vemos a importância e o pioneirismo argentino nas contribuições da Psicanálise à Odontologia.

Podemos referir-nos, segundo Aberastury $(1992,1996)$, há muito tempo, a uma colaboração de dentistas, pediatras e psicanalistas de crianças. Ela explicita não crer estar equivocada ao afirmar que, em seu país, pela primeira vez, profissionais da Odontopediatria solicitaram informações, bem como se aproximaram da análise.

Por meio da Psicanálise, a autora propõe contribuições que nos ajudariam a pensar sobre as relações na Odontologia a partir de um referencial psicanalítico. Ela (1996) compreende a angústia odontológica, associando-a à significação inconsciente e diz:

A angústia despertada pelo tratamento odontológico é de tipo irracional, pois nada do que acontece durante um tratamento dessa índole explica a intensidade da angústia que desperta, nem as reações que se observam [...] Com frequência, somos inteirados de que pessoas que sofreram operações estoicamente ou mulheres que suportaram partos complicados e que, em geral, tinham enfrentado com valentia situações difíceis na vida, paradoxalmente demonstram uma estranha incapacidade para enfrentar um tratamento odontológico. Em consequência dessas angústias, costumam esquecer a hora marcada antecipadamente, depois de um exame odontológico, chegar tarde e até preferem mentir ao dentista sobre o motivo de sua ausência, embora tenham perfeita consciência da irracionalidade de sua conduta [...] (ABERASTURY, 1996, p. 103).

Percebemos que, muitas vezes, as interfaces que se estabelecem entre Psicanálise e Odontologia situam-se entre as margens do lugar discursivo da oralidade e de suas ressignificações, o que também reconhecemos em nosso próprio dizer:

É indubitável que a fase oral é uma das mais importantes para a Odontologia. Esta profissão exerce suas atividades predominantemente na boca, isto é, lida diretamente com os significados da oralidade nos contatos. Além disso, o prolongamento da amamentação (natural e/ou artificial), bem como o uso de substitutos (chupeta, polegar e paninhos) podem ser a base para problemas odontológicos (BARRETO, 2002a, p. 32). 
Sobre os significados estabelecidos para a fase oral na relação dentistapaciente, também apresentamos:

O conhecimento desta fase é ainda de grande valor para a aproximação inicial entre dentista e paciente. O bebê na fase oral pode colocar coisas na boca, como brinquedos, e tem geralmente uma forte dependência do acompanhante. Quando tem dentes, suas atividades são incrementadas pelo morder e mastigar, o que expressa constantemente nas relações (BARRETO, 2002a, p. 32).

Por outro lado, entre os diversos conceitos da Psicanálise posicionados no contexto da Odontologia, podemos marcar que frequentemente aparecem as ideias de transferência e contratransferência que salientam a reedição do passado nas relações atuais:

A transferência é um acontecimento presente no relacionamento entre duas ou mais pessoas e que, pela intensidade e irracionalidade com que se apresenta, não pode ser explicado com base na situação atual, estando relacionado a vivências anteriores a esta, normalmente referentes às primeiras vinculações. No contexto dos atendimentos, pode se manifestar em atitudes positivas ou negativas em relação ao profissional. Como exemplos de transferência positiva, temos casos de pacientes que atribuem ao dentista propriedades onipotentes [...] ou aqueles que se dizem apaixonados pelo(a) dentista [...] A transferência negativa pode ser caracterizada por sentimentos de desconfiança, inveja, desprezo e irritação [...] (EMÍLIO-MARCHIONI, 2002a, p. 35).

A contratransferência, por outro lado, refere-se às emoções despertadas no profissional, como resposta aos movimentos afetivos de seu paciente, e que também estão vinculadas às vivências anteriores do primeiro. Esta pode ser positiva ou negativa. Por exemplo, uma dentista que está sendo constantemente assediada por seu paciente pode desejar concluir rapidamente o tratamento para ficar livre do assédio ou então desmarcar as consultas com este (EMÍLIO-MARCHIONI, 2002a, p. 36).

Barreto e Guirado (2009, p. 150), em uma visão psicanalítica distinta da habitual, já no termo da Análise Institucional do Discurso, falam sobre Psicanálise e Odontologia na rebeldia inconsciente:

[...] Em vez da obrigatoriedade de aproximações de noções como as de pulsão e recalque, entre outras clássicas à obra freudiana, aportes epistemológicos externos ao campo psi mobilizam o lugar psicanalítico [...] Localizemos: rebeldia na e da Psicanálise reconhecida com força instituinte. Não foi essa uma das grandes lições de Freud ao revisar tantas e tantas vezes seus conceitos?!

Conforme percebemos na literatura consultada, em alguns movimentos de contato entre Psicanálise e Odontologia, conceitos psicanalíticos passam a ser significados, ou aplicados, na Odontologia, imprimindo nesta área noções muito importantes entre os psicanalistas e os rumos das aproximações entre essas instituições distintas de conhecimento e práticas com implicações nas relações que se estabelecem no contexto odontológico. 
Pensamos ainda que a Psicanálise pode estabelecer interfaces com a Odontologia que problematize o lugar desta no campo do saber. A referência à oralidade por nós, psicanalistas, em contato com dentistas, não legitimaria a Ciência Dentária, a Odontologia em sua posição tradicional de conhecimento/fazer que trata dos dentes e da boca?

\subsection{Sobre Psicologia e Odontologia}

Neste momento, deslizamos da Psicanálise para o discurso na Psicologia de um modo geral no que se refere ao lugar que se depreende nele, nos limites do terreno em que fazemos debate, para a Odontologia. Sinalizamos que há distintos autores no mundo em diferentes épocas que contribuem para o conhecimento psicológico voltado para a área da Odontologia, entre os quais apresentaremos alguns.

Enfatizamos que pretendemos nos endereçar duplamente, em um zigue-zague discursivo, para as relações Psicologia-Odontologia e os relacionamentos dentistapaciente(-acompanhante) na literatura especializada, pois nosso trabalho se refere aos contatos entre Psicologia e Odontologia por meio de um grupo sobre as interações dentistas-pacientes-acompanhantes e as práticas odontológicas.

Vamos ao desafio!

Meng (1952) discorre sobre diversos assuntos referentes à Psicologia na prática odontológica, contribuindo há bastante tempo para pensarmos nos contatos entre Psicologia e Odontologia. Conforme nós reconhecemos, apesar da curiosidade antiga sobre possíveis interfaces entre essas áreas do conhecimento, muito há para ser construído.

Corah, O'Shea e Bissell (1986) referem-se à relação dentista-paciente, enfatizando as percepções e comportamentos dos integrantes desse contato. Corah et al. (1988), focando a relação entre dentista e paciente, falam de comportamentos percebidos no profissional e que minimizam a ansiedade do paciente, assim como aumentam a satisfação.

Peñaranda H (2000) discute sobre a Psicologia na prática odontológica. Dispõe para a Odontologia conceitos e técnicas psi. Comenta ainda fatores psicológicos 
presentes na patologia bucal, entre muitos outros aspectos. Com base em tal interlocutor, na Europa, nos Estados Unidos e na América Latina, a riqueza bibliográfica nesse campo, a partir dos anos sessenta, pode ser vista nas seguintes áreas: a relação dentista-paciente; questões referentes ao espaço, à decoração e ao instrumental; a educação do paciente, tanto individual, quanto coletiva, e as enfermidades psicológicas que têm implicações na cavidade bucal. Alguns assuntos que abordou, além da interdisciplinaridade entre Psicologia e Odontologia, foram: dentição e depressão, o paciente difícil em Odontologia, importância da Psicologia para a Odontologia, hábitos psicobiológicos e estilo de vida em pacientes com diagnóstico de câncer bucal.

No Brasil, encontram-se, a nosso ver, sobretudo, produções de cunho teórico nas relações entre Psicologia e Odontologia. Comentemos sobre algumas delas, bem como sobre trabalhos de pesquisa psicológica no terreno da Odontologia que consideramos relevantes para nossa temática.

Gil (1988) faz um estudo em seu mestrado em que analisa relatos verbais de alunos de Odontologia, por meio de questionário, com o intuito de identificar informações sobre o relacionamento entre dentista e criança, considerando que dessas se derivariam propostas de ensino de Psicologia aplicada à Odontologia. A sua análise dos relatos verbais identifica classes e itens de conteúdo verbal, sendo os resultados apresentados por meio da frequência de ocorrência desses.

Percebe, entre vários outros aspectos, que os estagiários utilizavam regras para a identificação de determinantes de situações problemáticas, muitas do senso comum, e geralmente obtinham baixa eficiência na resolução de problemas no atendimento odontológico, ressaltando a necessidade de capacitação dos alunos. $A$ mesma foi configurada em termos de identificação de estímulos do ambiente para serem evitadas situações-problema no atendimento em função da perspectiva teórico-metodológica em que o estudo se assentou.

Reconhecemos que sua pesquisa é inovadora, considerando a data do seu estudo e a ênfase concedida à relação dentista-paciente no âmbito do ensino de Odontologia.

$\mathrm{Na}$ atualidade, como analistas institucionais do discurso, não proporíamos a aplicação da Psicologia à Odontologia, pois, a nosso ver, seria repassar os conhecimentos psicológicos, que temos de forma globalizada, à Odontologia. Falaríamos da construção de interfaces entre Psicologia e Odontologia, produzindo 
possíveis mobilizações nesses dois campos, em suas relações/práticas, e não migração do saber de um campo profissional para outro.

Giron (1988), já citada anteriormente no tocante às relações entre Psicanálise e oralidade, apresenta o que considera os fundamentos da Psicologia na Odontologia, abrangendo assuntos referentes aos momentos da vida e suas peculiaridades, à ansiedade, à dor, às enfermidades e aos procedimentos para cirurgia, bem como outras considerações concernentes à prática odontológica.

Moraes e Pessoti (1991) explicam a providência do Conselho Federal de Educação de inclusão da Psicologia no currículo mínimo dos odontólogos em 1982. Pensamos que precisamos problematizar hoje como a Psicologia tem sido levada para a formação dos dentistas e as salas de aula dos cursos de Odontologia. Como uma Psicologia geral? Como uma Psicologia aplicada à Odontologia?

Klatchoian (1992) faz um estudo em seu mestrado e uma publicação em livro (1993), em que tematiza a relação dentista-paciente na clínica odontopediátrica. Reflete acerca de distintos aspectos que compõem tal relação, assim como expõe dimensões técnicas, visando ao incremento da colaboração e participação da criança na Odontopediatria. Mencionemos alguns dos assuntos abordados por ela: ansiedade e medo, dor, comportamento da criança no consultório odontológico e busca da participação/colaboração do paciente no tratamento em Odontopediatria. A autora considera a relação dentista-criança fundamental à profilaxia do medo e ao tratamento odontopediátrico.

Giglio, Guedes-Pinto e Duarte (1997) falam da importância da promoção de uma interação entre Psicologia e Odontopediatria para que o profissional tenha uma visão do mundo do paciente na assistência odontológica. Mencionam que conhecer princípios psicológicos auxilia na compreensão das reações das crianças, assim como na abordagem dos pais.

Corrêa (1998) possibilita aproximações entre Psicologia e Odontopediatria na primeira infância. O trabalho que organizou, reeditado várias vezes, inclui escritos com base psicológica de alguns de seus colaboradores.

Por exemplo, Amaral e Barreto (1998) que, com o intuito de desconstrução de pensamentos cristalizados na Odontologia, derivam em reflexão problematizações ao "responderem", numa interlocução imaginária, a questões comumente encontradas nas falas de odontopediatras referentes: ao sofrimento presente na experiência odontológica, às implicações de ocorrência ou não de trauma, ao 
benefício ou malefício da presença do acompanhante no atendimento e ao uso da técnica pelos dentistas. Com uma abordagem que não oferece receita de relacionamento, de um modo geral, buscam contribuir para fomentar o pensamento sobre as relações entre Psicologia e Odontopediatria, bem como entre dentista e paciente no mundo atual. Indagam ainda o que, quando e como tratar em confronto com exigências de produtividade.

Barreto (1999), em seu mestrado, investigou, com base no recurso da análise de representações, as relações entre dentistas, pacientes e acompanhantes na Odontologia para bebês, mais especificamente a afetividade nestas. A partir de análise de perfil de bibiliografia revisada de Psicologia referente à Odontopediatria, acena, entre outros aspectos, para sua percepção da forte marca da abordagem comportamental e da investigação quantitativa nos estudos.

Do ponto de vista de procedimentos, trabalhou com o discurso proveniente de entrevistas com dentistas e também do registro de falas de profissionais com bebês e acompanhantes em sessões odontológicas, bem como com as verbalizações/respostas dos odontólogos a perguntas formuladas logo após seus atendimentos: "o que foi mais prazeroso nesse atendimento?" "O que foi mais ansiógeno nessa sessão?"

O autor, inspirado pela perspectiva guiradiana, fala de lugares imaginados pelos dentistas para si próprios e suas práticas, seus pacientes e acompanhantes. Entre outros aspectos, encontra que o profissional, em seu estudo, constantemente se indiferenciou, nas representações ou imagens das relações, do bebê atendido, por meio de um "diálogo-monólogo", em que verbalizava por si mesmo e por aquele a quem oferecia cuidados. Uma síntese de seu mestrado é produzida, sob o formato de artigo em 2003, com o intuito de descortinar algumas relações que se repetem no terreno estudado.

Seger, em seu pioneirismo, constrói, com seus colaboradores, relações teóricas entre Psicologia e Odontologia. Seu trabalho, produzido inicialmente em 1988, foi ampliado e reeditado várias vezes. Por meio dele, a autora (2002) possibilita discutir sobre diferentes temáticas da Psicologia voltada à Odontologia, bem como aspectos específicos da Psicologia em diferentes especialidades odontológicas. O pensar desta interlocutora configura que não se pode tratar na Odontologia somente a boca, pois se deve ver o humano como um ser biopsicossocial. Aliás, chama atenção para não serem esquecidas as doenças 
psicossomáticas e comenta sobre diagnóstico global, integrando dimensões somáticas e psíquicas. Salienta também que os dentistas devem ter clareza a respeito de quando e de que modo encaminham o paciente ao psicólogo que, em princípio, não faria, em sua perspectiva, uma psicoterapia propriamente dita, mas uma terapia centrada na disfunção (TCD).

Galli (2002a) fala a respeito de mitos na Odontologia, como o do sadismo (o dentista é visto como sádico), o do dentista-psicólogo (o dentista é como se fosse um psicólogo/analista) e o de que o odontólogo perde seu paciente, se o encaminha ao psicólogo. A autora (2002b) também acena para a importância do dentista como instrumento da prática odontológica, evidenciando que a subjetividade tem influência no contato entre profissional e paciente.

Emílio-Marchioni (2002b) fala sobre a família no atendimento odontológico. Entende-a como um sistema em que existem papéis definidos e o não verbal nas comunicações. Enfatiza que o conhecimento do dentista de seu paciente abrange a visão do contexto, incluindo a dimensão das relações familiares.

Corrêa (2002) organiza um vasto e rico trabalho teórico, com muitos colaboradores, a respeito de um repertório diversificado de temáticas psicológicas importantes para a Odontopediatria. São discutidos aspectos como o estresse, a ansiedade, o medo, a birra do paciente, efeitos do tocar no comportamento das crianças, a importância dos limites, entre muitos outros.

No panorama de sua obra, Corrêa, Klatchoian e Hirata (2002, p. 586) dizem:

A Odontologia é uma profissão que está sujeita a uma grande quantidade de estressores que podem levar à exaustão profissional. O dentista precisa estar consciente desses estressores e tentar administrá-los, a fim de evitar uma insatisfação profissional que, quando repetida por sentimentos de frustração recorrentes, leva à exaustão e subsequente depressão.

Ao refletirem sobre o processo ensino-aprendizagem na Odontologia, Corrêa et al. (2002, p. 627) alertam:

A maneira de encarar o processo ensino/aprendizagem é um dos pontos que muitas vezes leva ao desentendimento entre professor e aluno. $O$ professor se caracteriza como um especialista em seu campo de atuação e, no entanto, nem sempre tem domínio sobre a área educacional e pedagógica [...]

Barreto (2002b), com base no brincar como recurso psicológico de acesso ao psiquismo, fala da relação entre dentista e sua equipe, o paciente e o acompanhante. O lúdico é entendido como forma possível de expressão do que acontece durante a vivência odontológica. 
Costa Junior (2002) aborda a Psicologia aplicada à Odontopediatria. Fala que a situação de tratamento odontológico é vista como ameaçadora e/ou, em termos potenciais, aversiva. Discute acerca do medo de dentista e do que se relaciona ao tratamento odontológico, entre outros aspectos.

Wolf (2002) discorre sobre a Psicologia na Odontologia, a relação entre odontólogo e paciente, entre outros assuntos. Para a autora, são encontrados em relação à figura do odontólogo estereótipos, como, por exemplo, o de alguém agressivo, ameaçador e sádico. Outra dimensão apresentada por essa interlocutora é a da exposição do profissional no trabalho a agentes potencialmente prejudiciais, fazendo menção acerca de afecções na coluna vertebral, formação de varizes, lesões por esforços repetitivos (LER), distúrbios osteomusculares relacionados ao trabalho (DORT), traumas oculares, barulho em excesso e permanente, entre outros aspectos.

No dizer dessa nossa interlocutora, parece-nos bem importante sua perspectiva de pensar sobre a relação dentista-paciente, caracterizando-a por uma desigualdade de forças. Acena diferentes ângulos em sua compreensão atenta da experiência odontológica, como, por exemplo, a exposição do paciente, isto é, de seu corpo, ao olhar do odontólogo:

[...] a posição deitada da cadeira, que expõe o corpo do cliente ao olhar do
profissional, pode provocar uma sensação de passividade e devassamento;
o lugar espacial ocupado pelo dentista, que se debruça sobre o paciente,
tolhe ainda mais seus movimentos, deixando-o vulnerável e indefeso; a
boca aberta que o impede de falar; o receio de que seu corpo emane
odores desagradáveis, como o mau hálito ou o cheiro característico da
infecção dental; a proximidade entre as faces dos participantes da relação,
que muitas vezes o induz a fechar os olhos para fugir da intimidade forçada;
o fato de estar submetido a instrumentos perfuro-cortantes desconhecidos
que podem produzir dor ou outras sensações indesejáveis; os sons agudos
e odores intensos, nem sempre agradáveis, são circunstâncias que inibem a
livre expressão do cliente, levando-o a se impacientar e a ter sentimentos
de inferioridade, dependência, humilhação e impotência (WOLF, 2002, p.
15-16).

Podemos, então, pensar na Odontologia marcada pelos dispositivos da correlação de forças e do olhar? Por esse crivo, ainda indagamos: como se produzem as relações na Odontologia? E se essas relações forem refletidas sob uma perspectiva de um lugar de escuta analítica institucional do discurso, como em nosso estudo? Quais os efeitos do "ouvir" para a visibilidade da tríade profissionalpaciente-acompanhante por parte de dentistas? 
Sobre a relação entre dentista e paciente, Prado, Freitas e Ribeiro-Rotta (2003, p. 270-271) dizem:

[...] Para uma boa relação CD-paciente, é necessário que o profissional tenha consciência de que, além do problema que o paciente apresenta, existe uma pessoa única, com expectativas, medos, traumas e esperanças $[\ldots]$

Mencionemos aqui que se, anteriormente, a expressão utilizada nas relações entre Psicologia e Odontologia era Psicologia aplicada à Odontologia, hoje esta, que é predominante, se entrecruza com os termos Odontopsicologia ou Psicoodontologia, o que, a nosso ver, mostra diferentes posicionamentos com vetores políticos no contato entre essas duas áreas.

Hirata (2003) discute sobre a transdisciplinaridade, contextualizando a crise atual de paradigma e a necessidade na Odontologia de um modelo científico novo, bem como familiarizando o dentista com o objeto de estudo da Ciência Psicológica. Fala do modelo recente da Odontopsicologia ou Psico-odontologia. Apresenta em seu dizer:

[...] Em vista da enorme irrupção de problemas ligados à subjetividade humana, tais como o estresse psicológico, a depressão, a síndrome de pânico, as fobias de diversas origens, os complexos de culpa, a alta criminalidade, as inúmeras guerras que assolam a humanidade, e mesmo a crise ecológica, a ciência não pode mais ignorar a existência pulsante da psique imaterial. O paradigma mecanicista-racionalista-positivista não possui modelos para o estudo de tais manifestações humanas e logo, inevitavelmente, este vem sendo substituído por uma nova maneira de pensar o Homem, o mundo e sua interrelação. É justamente neste novo paradigma que se enquadra a Odontopsicologia (HIRATA, 2003, p. 346).

Alves (2006) comenta que é fundamental a presença de disciplinas de Psicologia, Humanização em Saúde e Bioética em cursos da área de saúde. Enfatiza também a necessidade da Psicologia na formação dos dentistas.

Podemos explicitar alguns pontos que observamos quando a Psicologia se relaciona com a Odontologia, ultrapassando fronteiras de suas instituições!

Há muitas vezes uma tentativa de ampliação da compreensão do "acontecimento odontológico" pelo saber psi, provavelmente em busca de uma superação do organicismo ou, se quiserem nominar, por meio de "uma perspectiva integrativa".

Outro ponto relevante que salientamos é que nós, autores, pesquisadores, professores, agentes dos contatos entre Psicologia e Odontologia, muitas vezes, temos definido tais relações como uma Psicologia aplicada à Odontologia ou, numa forma mais contemporânea, uma Psico-odontologia ou Odontopsicologia. 
Se são inegáveis nossos esforços de tangenciamento entre essas áreas/instituições distintas do conhecimento com suas peculiaridades de conceitos e métodos de atuação, por outro lado, a aplicação do conhecimento das áreas psi na Odontologia não produziria, a nosso ver, o inter ou transinstitucional.

Mudança de paradigma parece o que tentamos fazer, quando buscamos nos afastar da Psicologia aplicada à Odontologia. Procuramos uma passagem desta para uma Odontopsicologia ou Psico-odontologia? Que área do conhecimento vai dominar na produção do saber? Esse é o "estado da arte" dos contatos da Psicologia com a Odontologia? Por que não o movimentarmos? 


\section{SOBRE GRUPO: DIMENSÕES CONCEITUAIS E ALGUMAS CONTRIBUIÇÕES DE TRABALHOS RELEVANTES PARA NOSSA TEMÁTICA}

Tendo em vista que trabalhamos com a Análise Institucional do Discurso, concretamente, num grupo de odontólogos com o alvo de discutir sua relação com a clientela e a profissão, faz-se necessária a apresentação, ainda que de forma breve, do modo como tem sido conceituado e concebido o trabalho com grupos em Psicologia e Psicanálise.

Partiremos, neste momento, do pensar sobre grupo e de considerações acerca da Psicologia/Psicanálise Grupal para, posteriormente, debruçarmo-nos sobre alguns trabalhos de reconhecida relevância no tocante à perspectiva psicológica em grupo na área de saúde e, mais especificamente, na Odontologia.

Destaquemos que são inúmeras as conceituações e modalidades de trabalho psicológico em grupo. Referimo-nos a um terreno descontínuo com peculiaridades teóricas e metodológicas a depender do autor e/ou escola de pensamento.

Carvalho (1986) aponta para a atenção da Sociologia para com as dimensões propriamente sociais referentes à existência dos grupos e da Psicologia Social para com os aspectos da vivência grupal, da sua intersubjetividade, com preferência pelos pequenos grupos.

Para a compreensão da Psicologia Grupal e os contornos estabelecidos para seu objeto, que não são uníssonos no campo teórico, ouçamos Osório (2003a, p. 11), que nos parece ter um ponto de vista interessante:

Em suma, a psicologia grupal tem como objeto de seu estudo os
microgrupos humanos, entendendo-se por tal todos aqueles nos quais os
indivíduos podem reconhecer-se em sua singularidade (ou perceberem uns
aos outros como seres distintos e com suas respectivas identidades
psicológicas), mantendo ações interativas na busca de objetivos
compartilhados.

Ao referir-se à definição de grupo, Zimerman (2000) a considera bastante vaga e imprecisa em se levando em conta a dispersão conceitual. Fala que, de acordo com vários autores, uma relação bipessoal já delineia um grupo. Faz menção à família, uma turma de formação espontânea, um grupo terapêutico, entre outros exemplos.

Uma distinção marcada é entre agrupamento e grupo: 
Creio que uma metáfora possa mais claramente definir a importante diferença entre o que é um conjunto (equivale a um agrupamento) e o que conceitua um grupo. Imaginemos um conjunto de instrumentos musicais de uma orquestra: enquanto os músicos estiverem antes do início do concerto, isoladamente, afinando os seus respectivos instrumentos, eles não passam de um mero conjunto, um agrupamento de instrumentos e músicos. A partir do momento em que o maestro começa a reger a orquestra, cada músico, e cada instrumento, assume o seu lugar, papel, posição e função, e, principalmente, dialoga e interage com todos os demais, compondo um grupo dinâmico, mais ou menos harmônico, conforme a qualidade da regência. (ZIMERMAN, 2000, p. 83)

Um autor do campo institucional, que é Bleger (1980/2007, p. 104), faz-nos pensar sobre grupo a partir de um fundo de indiferenciação:

Um grupo é um conjunto de pessoas que entram em interação entre si, porém, além disso, o grupo é, fundamentalmente, uma sociabilidade estabelecida sobre um fundo de indiferenciação ou de sincretismo, no qual os indivíduos não têm existência como tais e entre eles atua um transitivismo permanente [...]

Fernandes (2003a) posiciona-se acerca do número de pessoas para o início de um grupo. Considera que quatro já seria o suficiente, já que há a possibilidade de um faltar e permanecerem três, o que torna possível uma interação. Segundo o autor, caso o profissional acredite em seu trabalho e tenha "o grupo já dentro de si", será possível iniciar a atividade com um integrante e, aos poucos, irem surgindo novos participantes. Em termos de intervenções, ele as delineia: o que se faz/diz no grupo.

Sobre os trabalhos desenvolvidos em grupo, esses são múltiplos. Mello Filho (2007a) comenta sobre a prática de Heródoto de reunião com pacientes nas praças públicas na antiga Mesopotâmia com o intuito de discussão sobre suas doenças, seus males e sofrimentos. Também, entre outros aspectos, o autor apresenta contribuições de Pratt (1905), considerado o iniciador da psicoterapia grupal, com suas aulas sucedidas por discussões em grupo para pacientes tuberculosos em Boston; Le Bon (“A psicologia das multidões”); Mc Dougall ("A mentalidade do grupo"); Freud e a Psicanálise; Moreno e o Psicodrama; Kurt Lewin e a Dinâmica de Grupo; Pichon-Rivière e os grupos operativos ou de tarefa; Bion e a análise de grupos; Foulkes e a grupo-análise. Faz ainda menção às Escolas Francesa (Anzieu e Kaës, por exemplo), Portuguesa (com o destaque de Cortesão), Argentina (Grimberg, Bleger, Luchina, Langer, Dellarossa, Rodrigué e outros) e Brasileira. No movimento de nosso país, são considerados representantes como Waldermar Fernandes, Zimerman e Osório, com os quais já fizemos interlocuções. 
Falemos um pouco da técnica de grupos operativos ou de tarefa, por causa de sua inserção em nosso país e suas diferenças em relação à nossa estratégia de pensamento, como se verificará no decorrer de nosso trabalho.

Com base em Pichon-Rivière et al. (1983/2009), a teoria dos grupos operativos tem fundamentação nas ideias do próprio Pichon, e sua técnica se atém à tarefa em que teoria e prática têm resolução numa práxis concreta e permanente de cada campo que se assinala no "aqui e agora". Centra-se sua atividade em mobilizar estruturas estereotipadas em função da ansiedade suscitada por toda mudança (paranoide e depressiva). Com o esclarecimento, a comunicação, a aprendizagem e a resolução de tarefas, cria-se um novo esquema conceitual, referencial e operativo (ECRO).

Fernandes (2003b) refere-se ao aprofundamento de Pichon do estudo dos fenômenos no campo grupal para o objetivo não de terapia, mas, de operar em uma tarefa objetiva, exemplificando a de ensino-aprendizagem.

\footnotetext{
A principal função do coordenador dos grupos operativos é a de ajudar, por meio de intervenções interpretativas ou não, para que o grupo realize sua tarefa interna reflexiva, a fim de se colocar em condições de desenvolver sua tarefa externa, que é responsabilidade do grupo, e não do coordenador [...] (FERNANDES, 2003b, p. 201).
}

No terreno psi, nós nos ateremos, neste momento, a algumas reflexões sobre a Psicanálise em sua relação com os trabalhos em grupo, pois concebemos que a Análise Institucional do Discurso, nosso referencial de pensar, se, por um lado, é herdeira da Psicanálise, por outro lado, é um método diferenciado desta em sua forma clássica, sendo fundamental que localizemos nossas posições em pesquisa.

A dimensão de migração de cenas da Psicanálise individual para o trabalho psicanalítico em grupo é evidente. Assim, são esquecidos os contornos institucionais da Psicanálise tradicional, aplicando seus conceitos e técnicas inadvertidamente em quaisquer condições.

De acordo com Osório (2003b), a tentativa de abordagem dos grupos com o referencial da Psicanálise individual, mesmo com os esforços de renomados psicanalistas, não parece configurar um método congruente a não ser quando ocorre liberação relacionada à "camisa-de-força" da técnica original e ao enriquecimento por meio de aportes de outras referências epistemológicas. 
Acrescentemos ao seu dizer: é o que fazemos com a Análise Institucional do Discurso, que tem em seu estofo a Psicanálise, mas não se reduz ao que nela está instituído.

Falando de Psicanálise, cabe-nos apontar que Freud, o pai dessa instituição de conhecimentos e práticas, não propôs uma técnica psicanalítica grupal, mas, em seus escritos, há referências a grupo e uma denominada Psicologia Social. Em proximidade com Mello Filho (2007a), podemos sinalizar que textos freudianos, como "Totem e Tabu" (1913/1980), "Psicologia de grupo e a análise do ego" (1921/1980), “O mal-estar na civilização" (1930/1980), "Moisés e o Monoteísmo" (1939/1980), entre outros, enriquecem muito uma discussão que tem como objeto as relações da Psicanálise com o "grupo" e/ou a sociedade. Nossas expectativas nesta tessitura discursiva, contudo, são mais localizadas. Pensemos em algumas contribuições de Freud acerca de uma noção de grupo.

Sobre a concepção de grupo de Freud, não podemos esquecer de marcar que, em "Totem e Tabu", aparece a ideia de uma "mente coletiva" e de um processo emocional que atravessa gerações. Em "Psicologia de grupo e a análise do ego", percebemos que, na posição deste autor, o contraste entre as psicologias individual e social (ou de grupo) perde muito de sua nitidez. E isso em função do ponto de partida teórico. Na vida mental do indivíduo, considera algo como um outro; de modo que, desde o princípio, em um sentido ampliado, a psicologia individual é simultaneamente social. Só em condições incomuns, a psicologia individual é compreendida por ele sem que sejam consideradas as relações do indivíduo com os outros. Sobre sua concepção de grupo, Freud ainda valoriza ideias como as de libido, identificação e ideal do eu. (FREUD, 1980; PAGÉS, ÁVILA, 2003).

Em relação ao texto de Freud "Totem e Tabu”, Pagés e Ávila (2003, p. 81) falam:

Muitos anos depois desse texto, a geração de psicanalistas que se dedicou
aos fenômenos grupais foi-se apropriando cada vez mais da noção de um
aparelho psíquico grupal (expressão de René Kaës), entendendo-o como
um constructo amplo, descritivo das operações complexas que se efetuam
intersubjetivamente e que não se reduzem apenas a manifestações atuais
de interações momentâneas, mas sim a uma totalidade transubjetiva e
transgeneracional.

Sinalizaremos, então, nossas posições a respeito do que expusemos. Resulta de recortes e costuras a partir das contribuições dos autores mencionados: 1) pensamos em um grupo como composição de interações com base em lugares 
assumidos e atribuídos na busca de objetivos compartilhados; 2) reconhecemos uma possibilidade de movimentos de indiferenciação e diferenciação (constituição de singularidades) nas configurações grupais; 3) não entendemos um grupo como uma "mente grupal”, nem o psiquismo como um "grupo internalizado", identificando concepções de mente e grupo; 4) compreendemos que a migração de conceitos e técnicas da Psicanálise individual para o trabalho em grupo é problemática por causa das particularidades das condições que se instituem em ato no fazer/pensar em grupo e 5) não pretendemos naturalizar, a partir de teorias da psicologia grupal, nem desses nossos assinalamentos, o que é um grupo antes que ele aconteça, o que seria reproduzir, a nosso ver, o instituído ou nos localizar em visões que relacionam grupo à reedição de uma lógica inscrita no passado.

[...] O que chama a atenção é que, com raríssimas exceções, quase todos tomam o grupo como um fato social e psíquico preexistente à sua compreensão ou aos objetivos e intenções que deram origem. Ou seja, o grupo antecede à prática que o forma e está lá, imóvel em sua facticidade, esperando que as diversas teorias desvelem pouco a pouco sua natureza. (COSTA, 1989, p. 42).

Façamos, mais uma vez, interlocuções com Costa (1989, p. 14):

[...] Qual a possibilidade que temos de definir, sub specie aeternitatis, o que é um grupo? Não teríamos receio em responder, nenhuma! O grupo, sendo composto de sujeitos, não tem nenhuma realidade em si, imutável e idêntica a si mesma [...] O grupo é uma instituição social. E das instituições sociais [...] o que se pode dizer é que elas autoinstituem permanentemente suas realidades $[\ldots]$

Sendo mais específicos e possivelmente mais coerentes com nossa estratégia de pensamento, indicaremos mais um aspecto de nossa compreensão acerca do tema, que nos afasta de perspectivas globalizantes e essencialistas: pensamos em um (artigo indefinido) grupo como uma instituição social (e não separado da noção de instituição) ou relações entre seus atores. Acrescentamos: entendemos tais relações articuladas a seus lugares de enunciação, bem como constituídas no e do fazer grupal em ato. Isto é: um grupo como uma instituição (relações institucionais) discursiva sem qualquer transcendência ao que nele e dele se constrói. Encontramse, portanto, no presente delimitadas as regiões de nosso recorte para entender a temática "grupo", o que se afina à Análise Institucional do Discurso, cujos fundamentos esclareceremos no capítulo sobre método.

Passaremos, a partir de então, a contemplar alguns trabalhos psicológicos significativos com profissionais da área de saúde e, mais particularmente, no que tange à Odontologia no campo grupal. 


\section{Comecemos por Balint!}

Balint foi um psicanalista húngaro, criador dos fundamentos da Psicologia Médica. Na década de 1950, na Tavistock Clinic, na Inglaterra, ele publicou um trabalho, bem como o divulgou ao mundo, o que deveria ter transformado a Medicina tradicional (MELLO FILHO, 2007b).

Balint (2007) explicita que seu objetivo era realizar um exame da relação entre médico e paciente, da "farmacologia do médico" como substância, sendo o profissional posto em condições de ver sua experiência cotidiana com um interesse renovado de modo a perceber que problemáticas ignoradas pela Medicina suscitam atividade desnecessária, assim como sofrimento e irritações indevidas aos pacientes. Em seu trabalho, valoriza a discussão em grupo de médicos sobre suas vivências com pacientes, seus casos clínicos. Por meio de suas contribuições, percebemos uma compreensão mais ampla da Medicina e dos pacientes fomentada nos médicos.

Segundo Branco (2003), o grupo Balint se atém a casos clínicos reais, o que possibilita aprender sobre a prática e contribuir para a formação. Através dos pequenos grupos, há uma alternativa para a reflexão acerca do que se refere à ordem do psíquico e humano.

Vários trabalhos e movimentos surgiram a partir da perspectiva Balint no mundo. Quanto a Medicina e a área de saúde, hoje em dia, poderiam enriquecer-se e, algumas vezes, são acrescidas com atividades em grupo tipo Balint coordenadas por um profissional que trabalhe em saúde mental?

Para ilustrarmos os desdobramentos possíveis da obra de Balint, sinalizemos o trabalho de Pedrosa (1986), em que grupos Balint foram realizados durante seis semanas e periodicidade de duas horas de duração semanais com graduandos e residentes de Medicina, apontando possibilidades, apesar do baixo índice de comparecimento dos participantes.

Também faremos comentários sobre uma experiência, a nosso ver, híbrida, encontrada na literatura especializada, com o grupo Balint "grupoanalítico".

Pisani (2005) afirma que chamou o grupo Balint de grupoanalítico à medida que sua implantação foi com o referencial de Foulkes. Refere-se a um grupo realizado com profissionais diversos para discutir as problemáticas e dificuldades emocionais encontradas no tratamento de pacientes neurológicos, destacando temas do processo grupal, por exemplo, o conflito entre impotência e onipotência. 
É indiscutível o pioneirismo de Balint na riqueza e no vanguardismo de suas ideias e práticas. Além disso, a partir dele, experiências ímpares são encontradas na perspectiva de suas contribuições. Uma das diferenças nossas em relação a esse interlocutor, que tanto reconhecemos em seu caráter inovador, é que não pensaríamos, como ele, no médico como "substância", nem na Medicina por meio de uma compreensão psicanalítica da relação profissional-paciente permeada por imagens médicas provenientes da Farmacologia. Nosso crivo epistemológico é outro. Obviamente, acenamos com tal distinção, o que pode parecer ingênuo, de um lugar histórico adiante em relação aos seus delineamentos de grupo com profissionais de saúde.

Outra perspectiva de trabalho grupal no campo da saúde são os grupos de reflexão e os de discussão, abordados por Fernandes (2003c).

Segundo o autor supracitado, o grupo de reflexão ocorre, sobretudo, nas instituições que formam grupoterapeutas e coordenadores de grupo e esta expressão passou a ser utilizada nos anos 1960 com a realização de uma experiência por Bernard, Ulhoa e psicanalistas diversos, com residentes de Psiquiatria do Instituto Borda na Argentina, com o objetivo de proporcionar a elaboração de tensões do contato desses com pacientes psiquiátricos, professores e coordenadores da mencionada instituição de forma a colaborar com o aprendizado.

Na década de 1970, diz nosso interlocutor, tais autores, juntamente com outras pessoas, como, por exemplo, Dellarossa, buscaram sua adaptação ao Instituto de Técnicas Grupais da Associação Argentina de Psicologia e Psicoterapia de Grupo. Faz ainda menção à obra de Dellarossa (1979), "Grupos de reflexión”, explicitando, com rigor conceitual, que, nestes grupos, não há tema pré-fixado em diferenciação do que comenta como grupos de discussão.

Sobre os grupos de reflexão, Dellarossa (1979), entre outros aspectos, delineia-os como uma experiência formativa importante, permitindo a elaboração de tensões engendradas pelas atividades e sem expectativas terapêuticas. Fala da finalidade de questionar a problemática referente à aprendizagem e à inserção dos alunos na instituição. Por outro lado, chama atenção que os coordenadores não poderiam sobrepor a função de professores e deveriam possuir a menor participação que fosse possível no que concerne à organização do instituto.

No Brasil, Muniz e Chazan (1992) comentam sobre grupos de reflexão desenvolvidos durante o curso de Medicina. Falam de grupos que se constituem em 
média com até vinte alunos, havendo geralmente coordenação por uma dupla de professores e discussão de situações experienciadas pelos alunos, tanto na vida acadêmica, quanto no relacionamento com os pacientes de um modo geral. Tais grupos, de acordo com nossos interlocutores, não possuem um caráter terapêutico expresso. Neles, os coordenadores permitem aos alunos um espaço para a elaboração de emoções que, por vezes, produzem dificuldade ao aproveitamento do estudo.

Também no território brasileiro, no tocante a grupos acerca da educação médica, Zimerman (2000) mostra exemplos de grupos de reflexão. Fala, entre outros aspectos, de eles desenvolverem o "senso de identidade médica" e outros atributos da profissão.

Na literatura especializada, também há referência à expressão "grupos focais" (com um foco). Borges e Santos (2005) discutem sobre eles, levando em conta suas aplicações, potencialidades e seus limites. Mencionam que há um aumento da escolha desta técnica em estudos tanto na área de saúde, quanto nas Ciências Sociais. Falam também desses grupos em referência à implementação e à avaliação de programa social e educativo. Fazem menção a entrevistas grupais e/ou grupos de discussão, bem como a uma duração em média de uma hora e meia por encontro.

Macedo, Nogueira-Martins e Nogueira-Martins (2008, p. 336) referem-se aos grupos de reflexão sobre a tarefa assistencial:

O trabalho com o Grupo de Reflexão sobre a Tarefa Assistencial constitui,
assim, uma instância de reflexão sobre o cotidiano da prática assistencial
com a possibilidade de detecção de entraves e pautas estereotipadas de
conduta no exercício profissional. O manejo técnico utilizado nesse tipo de
grupo consiste em que seu coordenador centralize a discussão no tema
que, como um denominador comum, emerge da livre discussão que se
estabelece com base nos relatos das vivências clínicas e assistenciais. O
coordenador, por meio de breves estímulos, colocações e indagações, à
mercê de uma capacidade de discriminação e síntese, ajuda o grupo a
sentir, indagar e incorporar um conjunto de valores que convergem para as
atitudes profissionais.

A participação nesses grupos, dizem os interlocutores, pode ser multiprofissional, mas também por categorias específicas. Os encontros podem ocorrer com duração programada (quatro ou oito, por exemplo) ou realizar-se permanentemente (toda semana ou de forma quinzenal), com um tempo de duração de aproximadamente uma hora. 
Podemos localizar que, se nossa perspectiva de trabalho tem muitos pontos de contato com os grupos de reflexão e de discussão, ela se diferencia muito deles pela análise institucional discursiva que estabelecemos como estratégia de pensar.

Neste momento, apresentaremos algumas considerações acerca de trabalhos em grupo na Odontologia.

Aberastury foi pioneira com suas contribuições psicanalíticas no campo da Odontologia. A autora (1972) explica que a combinação dos trabalhos psicoterápicos em grupo analiticamente inspirados com crianças e também com acompanhantes produz efeitos excelentes. Saimovici (1972) refere-se a grupo de crianças que ocorria simultaneamente ao de acompanhantes, tendo o seguinte formato: eram abertos, toda semana e com duração de quarenta minutos. Seu ponto de urgência era a ansiedade que se reativa com o tratamento odontológico e ocorria em paralelo a esse. O grupo infantil utilizava-se de recursos lúdicos para a expressão de ansiedades a serem interpretadas.

Aberastury (1996), ao mencionar sobre grupos com crianças que possuíam dificuldade diante do trabalho odontológico, diz ainda que o manejo técnico nessas atividades se aperfeiçoou gradativamente, sobretudo com o início do grupo com mães ou pais acompanhantes.

Emílio-Marchioni (1998) faz uma pesquisa sobre os vínculos ao serem atendidos pacientes especiais em uma clínica-escola de Odontologia com base em um grupo com oito alunos. Busca compreender o que dificulta os encontros entre 0 aluno de Odontologia e o paciente especial, bem como o impacto da deficiência. Faz uma leitura a partir do referencial de Pichon-Rivière e, em suma, sinaliza a importância da criação desses espaços de reflexão.

Carniel (2001) faz uma pesquisa por meio de grupos operativos com pacientes em tratamento por desordens temporomandibulares com um modelo teóricomedológico baseado em Pichon-Rivière. A análise temática de conteúdo realizada é elucidativa do conhecimento dos pacientes sobre a problemática vivenciada, entre outros aspectos.

Gorter, Eijkman e Hoogstraten (2001) falam de uma pesquisa sobre um programa de aconselhamento de carreira para odontólogos, investigando os efeitos sobre o burnout, considerado um resultado possível da inadequação crônica ao lidar com o estresse em termos ocupacionais. O programa constitui-se de aconselhamento individual e também de sessões grupais a partir de intervenção 
cognitivo-comportamental. Nesse estudo, os autores concluem, com algumas ressalvas, que o programa preventivo possui efeito favorável no burnout entre odontólogos. Os autores ainda explicitam que não tem sido inserida no currículo odontológico atenção às expectativas das pessoas no contexto profissional.

Em seguimento à pesquisa mencionada, foi realizado por Te Brake et al. (2001) um estudo com a intenção de investigar os efeitos de longa-duração do programa em relação a burnout realizado com os dentistas. Evidências indicam, entre outros aspectos, a redução de efeitos do programa com o tempo. São discutidas possíveis explicações para tais achados.

Como falam de "grupo" e pela inovação/atualidade de seu trabalho, apresentamos que, no cenário da internet, Buchanan e Coulson (2007) desenvolvem um estudo com a finalidade de investigar o contexto por meio do qual indivíduos com ansiedade em relação aos cuidados odontológicos acessam um grupo de suporte online e suas experiências. A metodologia adotada inclui questionário e análise qualitativa. Resultam temas que refletem as motivações dos participantes, por exemplo, procurar ajuda e dividir medos. O estudo sugere que, para muitos indivíduos, foi uma experiência proveitosa o suporte online.

A partir deste momento, passaremos ao capítulo sobre o método de nossa pesquisa em que discutiremos acerca da estratégia de nosso trabalho em grupo com dentistas: a Análise Institucional do Discurso. 


\section{RECORTE METODOLÓGICO}

\subsection{Considerações sobre nosso referencial}

Com o crivo do pensamento foucaultiano, mas atribuindo sentido próprio, Guirado (2007, p. 14), no prefácio de "Psicologia, pesquisa e clínica: por uma análise institucional do discurso", define método como "uma estratégia de pensamento que se organiza em torno de um conceito, ou de conceitos”. Com base em Galvão e Serrano (2007), podemos referir-nos aos princípios que dão fundamento à abordagem que seguimos.

Entendemos que não temos consciência, de modo globalizante, de nós mesmos e do outro, de nosso estudo, o que é condizente com muitas perspectivas: entre outras, a psicanalítica e sua noção de inconsciente; a histórica e seu reconhecimento de um contexto espaçotemporal, e a epistemológica, já que falamos de um recorte no campo do saber.

Acenamos:

[...] os aspectos que se extravasam de nosso recorte teórico-metodológico não nos negam, a nosso ver, a especificidade de um discurso, com consistência e crítica, que não é objetivo, distanciado de seu objeto para "alcançá-lo", mas construído nas e das relações de (in)consciência com ele (BARRETO, 1999, p.17).

Temos, portanto, que delinear o referencial que perpassa todo nosso trabalho, considerando-o não como "verdade absoluta", mas, de modo parcimonioso, como uma delimitação no terreno do conhecimento.

Nossa estratégia de pensamento é a Análise Institucional do Discurso, método que vem sendo construído por Guirado (1986/2004, 1987/2004, 1995/2006, 2000, 2007, 2009) e que passa por diferentes influências: Psicanálise, Análise de Instituições Concretas, Análise do Discurso Francesa e as contribuições de Michel Foucault. Com essas matrizes conceituais, o pensamento inovador da autora singulariza-se a partir das condições de produção de seu discurso, possuindo desenho próprio. Assenta-se também, à exceção de movimentos de um suposto saber totalizante e da aplicação teórica imediata (teoricismo), em uma maneira de 
conceber e operar com a análise de discurso de forma localizada que articula concepções específicas de instituição, discurso, sujeito e análise.

Uma ressalva faz-se necessária: por seu balizamento em uma perspectiva institucional-discursiva, o método adotado por nós distingue-se da Psicanálise tradicional com base na clínica e do que comumente se define como objeto na denominada "Psicologia grupal".

Para sustentarmos uma Análise Institucional do Discurso em grupo, tomemos os eixos nucleares do referencial que seguimos.

\subsubsection{Sobre uma específica noção de instituição}

Em "Instituição e relações afetivas: o vínculo com o abandono", trabalho inicialmente publicado em 1986, Guirado (2004, p. 44) segue o conceito de instituição do sociólogo Guilhon Albuquerque, traduzido por ela "como um conjunto de práticas, ou de relações sociais, que se repetem e se legitimam enquanto se repetem".

A autora apresenta na obra supramencionada a distinção de Guilhon Albuquerque entre agentes institucionais e clientela, sendo os primeiros compreendidos como profissionais, agentes privilegiados ou subordinados (por exemplo, em formação), cuja ação dá concretude ao agir da instituição. Guirado (1986/2004, p.47) delineia que a clientela é visada pela ação institucional e que as relações dos agentes institucionais com ela são definidoras, na compreensão guilhoniana, do objeto institucional, sendo que: "[...] o objeto de uma instituição é institucionalizar (re/produzir e re/conhecer) uma relação de clientela, e é produzir clientes para seus agentes e produzir agentes para seus clientes."

Em "Psicologia Institucional", inicialmente publicado em 1987, no capítulo com a colaboração de Maria Luísa Sandoval Schmidt, Guirado (2004, p. 110) refere-se a Guilhon Albuquerque:

Sua contribuição fundamental é a de fazer pensar a instituição como conjunto de práticas sociais que se reproduzem e se legitimam, num exercício incessante de poder; um poder entre agentes, dos agentes com a clientela; um poder na apropriação de um certo tipo de relação como própria, como característica de uma determinada instituição. 
Esta prática se articula sempre às representações, que são efeitos de reconhecimento e desconhecimento das relações concretas [...]

A partir da Psicanálise e da Análise de Instituições, desenha-se na obra supramencionada:

[...] Trabalhar com Psicologia Institucional não seria, portanto, trabalhar no espaço físico de uma instituição [...] Seria sim, trabalhar com as relações tal como se organizam no discurso de determinada prática institucional (GUIRADO, 1987/2004, p. 114).

\subsubsection{Sobre o discurso}

É mister que comentemos que houve um movimento articulatório na estratégia trabalhada por Guirado com o contato com a Análise do Discurso Francesa de Maingueneau em "Psicanálise e análise do discurso: matrizes institucionais do sujeito psíquico" (2006), publicado inicialmente em 1995, e "A clínica psicanalítica na sombra do discurso: diálogos com aulas de Dominique Maingueneau" (2000).

Com base em Maingueneau, em "Novas tendências em análise do discurso" (1997, p. 14), surge um recorte para o discurso a partir da visão de Foucault:

um conjunto de regras anônimas, históricas, sempre determinadas no tempo e no espaço que definiram em uma época dada, e para uma área social, econômica, geográfica ou linguística dada, as condições de exercício da função enunciativa.

Maingueneau (1997, p. 14) complementa: trata-se de levar em conta a "enunciação como o correlato de uma certa posição sócio-histórica na qual os enunciadores se revelam substituíveis [...]" .

Na perspectiva pragmática, a linguagem é considerada como uma forma de ação; cada ato de fala (batizar, permitir, mas também prometer, afirmar, interrogar, etc.) é inseparável de uma instituição, aquela que este ato pressupõe pelo simples fato de ser realizado. Ao dar uma ordem, por exemplo, coloco-me na posição daquele que está habilitado a fazê-lo e coloco meu interlocutor na posição daquele que deve obedecer [...] (MAINGUENEAU, 1997, p. 29-30).

Por intermédio de Maingueneau, a linguagem pode ser compreendida como um modo de ação indissociado de uma instituição. O discurso pode ser configurado como cena enunciativa, não sendo suas condições de produção entendidas como externas a ele. Nessa perspectiva, entre outros aspectos, chama atenção a noção de polifonia, vozes, e divisão no discurso, cuja heterogeneidade se mostra por meio 
da ironia, pressuposição, negação, discurso indireto livre, palavras entre aspas, entre outros indicadores (GUIRADO, 1995/2006).

Com base em Maingueneau, Guirado (2000, p. 87) expressa:

[...] A cenografia, por sua vez, implicará nas formas concretas mais particulares em que os personagens atribuir-se-ão papéis e os atuarão. Tudo, sempre, como discurso. Na rede discursiva, portanto.

Guirado (2000, p. 99) dialoga com a aula de Maingueneau sobre "Gêneros Discursivos" em que ele delineia:

[...] o discurso é sempre pôr em relação [...] O problema dos parceiros não é somente transmitir ideias, mas é fazer reconhecer o lugar a partir do qual está falando. E fazer o outro reconhecer o lugar a partir do qual está recebendo o discurso. Mas, muitas vezes, há um conflito. Uma vez que cada um dos parceiros pretenda ser reconhecido num outro lugar [...] Isso é fundamenta! Porque é unicamente a partir dos lugares que as palavras podem tomar um sentido [...]

\subsubsection{Sobre o sujeito}

Especificando melhor sua visão de sujeito, Guirado (1995/2006) cria uma metáfora de conceito dobradiça de sujeito em que aponta para o movimento das singularidades no discurso e, simultaneamente, "aquilo que parece ser o regime discursivo [...] numa formação social [...] entre suas formas de acontecer e se instituir" (p. 86).

Nas palavras de Ribeiro (2007, p. 248), toma o seguinte contorno a visão guiradiana de "sujeito-dobradiça":

[...] a metáfora do sujeito-dobradiça expressa conceitualmente a condição de sujeito institucional como subjetividade instituída nas (e instituinte das) práticas discursivas [...] faz entrever no espaço-tempo desse movimento condições de produção do discurso e efeitos de subjetivação [...] enuncia práticas institucionais e subjetividade.

\subsubsection{Sobre a Análise Institucional do Discurso}


Guilhon Albuquerque (1986) em "Instituição e poder" tem um entendimento das instituições por meio de níveis e planos de análise, enfatizando as relações de poder.

Guirado (1986/2004), em "Instituição e relações afetivas: o vínculo com o abandono", desenha sua análise do ângulo das relações imaginárias. Enfatiza, a partir de suas fontes, os reconhecimentos, assim como os desconhecimentos no discurso.

Dizer que o discurso é ato dispositivo é acentuar seu caráter de dizer, em vez de acentuar o dito. Ou seja, é atentar para o que se mostra enquanto se diz: que tipo de interlocução se cria, que posição se legitima na asserção feita, que posição se atribui ao interlocutor, o jogo de expectativas criado na situação, como se respondem ou se subvertem tais expectativas, e assim por diante. Qualquer interpretação, isto é, qualquer sentido a que se chegue será uma construção que considere todo esse modo de produção, ou melhor, o contexto (em) que (se) produz a fala e suas razões (seus sentidos). E esse será o discurso em análise [...] (GUIRADO, 2000, p. 34).

Podemos localizar que a Análise Institucional do Discurso é uma forma de trabalhar institucionalmente com os discursos que nos faz pensar, segundo Guirado (2000, p. 65), na "análise do modo como se organiza o discurso (exatamente para diferenciar das análises conteudísticas)".

Nossa análise em ato assim se configura com base em Guirado (1987/2004, p. 119) em "Psicologia Institucional" como:

Uma análise do cotidiano, no cotidiano, e por meio de uma fala que veicula o reconhecimento/desconhecimento sobre ele [...] Seu "efeito" é o de estabelecer, na legitimação do vivido, um corte que faz pensar.

Salientemos ainda que Guirado (1987/2004, 1995/2006, 2000) nos faz considerar sua noção de transferência institucional, não enfatizando uma história que ultrapassa as relações institucionais, ou uma repetição da infância na atualidade, mas uma reedição de relações por meio de uma estrutura de lugares, no plano da cenografia no discurso, nos movimentos dos papéis e expectativas no interior de uma instituição. É importante levarmos em conta que "esta intervenção será, até porque psicológica, inegavelmente, institucional e política” (GUIRADO,1987/2004, p. 124).

Guirado (2009), em seu trabalho de livre docência, sustenta conceitualmente a Análise Institucional do Discurso como método de pesquisa na área de Psicologia. Refere-se também a ele como estratégia de pensar em intervenções em outras instituições. Seu objeto provém de uma aproximação da Psicologia à Psicanálise: as relações imaginadas e simbolizadas pelos que as produzem. 
Por ser um nome importante no pensamento de Guirado, ouçamos Foucault. Em "Microfísica do poder", esse autor (1979/2007) nos permite refletir acerca do exercício do poder que não se situa apenas no Estado, mas, inclusive, em nível mais elementar e cotidiano.

Esclarece Machado (1979/2007, p. 10):

[...] não existe em Foucault uma teoria geral do poder. O que significa dizer que suas análises não consideram o poder como uma realidade que possua uma natureza, uma essência que ele procuraria definir por suas características universais. Não existe algo unitário e global chamado poder, mas unicamente formas díspares, heterogêneas, em constante transformação. O poder não é um objeto natural, uma coisa; é uma prática social e, como tal, constituída historicamente [...]

Foucault (1984/2006, p. 276) menciona:

[...] quando se fala de poder, as pessoas pensam imediatamente em uma estrutura política, em um governo, em uma classe social dominante, no senhor diante do escravo etc. Não é absolutamente o que penso quando falo das relações de poder. [...] São, portanto, relações que se podem encontrar em diferentes níveis, sob diferentes formas; essas relações de poder são móveis, ou seja, podem se modificar, não são dadas de uma vez por todas $[\ldots]$

Especificando nosso delineamento de uma análise institucional do discurso em grupo, ouçamos mais uma vez Guirado (1987/2004, p.125) em "Psicologia Institucional":

[...] Pontuar, interpretar e, com isso, "desconstruir" (a) o interjogo dos papéis assumidos no grupo, (b) as fantasias e afetos que o acompanham, (c) a atribuição e assunção de lugares de poder e (d) o significado que isto assume, é o fazer do psicólogo no grupo [...]

Por conseguinte, no imaginário, construído na rede de relações institucionais e na correlação de forças dos lugares atribuídos e assumidos em grupo, é que intervimos neste estudo sob uma perspectiva de escuta assentada na obra de Marlene Guirado a partir dos (con)textos de onde a pronunciamos.

\subsection{Participantes}

Participaram deste estudo dez dentistas do sexo feminino em pós-graduação em uma entidade de ensino de Odontologia do estado de Sergipe. As participantes tinham idade entre vinte e um e quarenta e sete anos, bem como tempo de experiência variável: de menos de um ano a mais de vinte anos. Algumas se formaram em universidade pública; outras, em universidade privada. 
As participantes estavam cursando especialidade ou aperfeiçoamento profissional em distintos ramos da Odontologia: três faziam especialidade em Endodontia (área que trabalha com canais), cinco faziam especialidade em Ortodontia (área que trabalha com os aparelhos ortodônticos) e duas faziam aperfeiçoamento em Dentística (área de atividades odontológicas referentes às restaurações e aos procedimentos estéticos em uma clientela diversificada). Essas duas últimas participantes mencionadas já tinham título de especialista em outra área da Odontologia ou Saúde.

Salientemos que as dentistas dos cursos de Endodontia e Ortodontia estavam no início da especialização, não tendo ainda começado as atividades de atendimento clínico específicas da pós-graduação. As participantes do aperfeiçoamento em Dentística o estavam finalizando. Expliquemos, porém, que todas as dentistas tinham vida profissional atuante fora da entidade de ensino, tendo com frequência feito cursos diversos para um bom preparo profissional, compromisso com o estudo, trabalhando em serviço público e/ou consultório particular na capital e, às vezes, também no interior. Atendiam, de um modo geral, a uma clientela diversificada, comumente referente não só a uma especialidade odontológica, tendo algumas dentistas poucas crianças como pacientes.

Ressaltamos também que as dentistas tiveram o desejo de participar desta pesquisa e foram devidamente informadas sobre ela. Houve, inicialmente, a autorização do diretor da entidade de ensino relacionada à investigação, em formulário próprio do Comitê de Ética do Instituto de Psicologia da Universidade de São Paulo, ao qual foi submetido e aprovado o projeto de pesquisa. Posteriormente, após definição, as participantes, no primeiro encontro agendado, preencheram o termo de consentimento livre e esclarecido para os voluntários à pesquisa (APÊNDICE).

Enfatizamos também que, em função de uma postura ética, as participantes deste estudo tiveram seu anonimato preservado, através da criação de nomes fictícios, bem como não foi nomeada a entidade de ensino em questão.

\subsection{Recurso de investigação}


Este estudo se caracterizou como uma pesquisa-intervenção por meio da Análise Institucional do Discurso, em grupo e ato, com objetivos definidos, que teve seis encontros de aproximadamente uma hora e meia de duração com as dentistas participantes.

As reuniões ocorreram no segundo semestre de 2008, às quintas-feiras, das $19 \mathrm{~h} 30 \mathrm{~min}$ às 21 horas. A regularidade dos cinco primeiros encontros foi semanal; do quinto para o sexto encontro, houve um intervalo quinzenal em função de ajustes necessários decorrentes da disponibilidade de horários das participantes.

Houve, para a consecução do estudo, um roteiro com indagações eventualmente utilizadas no decorrer dos encontros: como são suas relações com pacientes e acompanhantes? Como é o atendimento de vocês? Como é um dia de rotina? Quais são as facilidades e empecilhos na Odontologia? Como é a formação em Odontologia? Quais são os fatos mais marcantes que lembram com pacientes e/ou acompanhantes? Salientemos que não nos víamos na obrigatoriedade de formular tais perguntas, pois enfatizamos a fala livre que fluía das participantes do grupo e, além disso, muitos desses pontos emergiram espontaneamente nas cenas discursivas.

A Análise Institucional do Discurso em ato atentou-se às produções discursivas das dentistas sobre seus atendimentos, suas relações com pacientes e acompanhantes. Os discursos foram gravados em áudio, um gravador com fita cassete e três gravadores digitais, distribuídos estrategicamente na sala onde nos encontrávamos, para posterior transcrição.

Durante os encontros, o pesquisador utilizava uma prancheta com papéis para breves anotações dos movimentos que reconhecia no grupo com as dentistas que Ihe possibilitassem intervenções analíticas. Além disso, uma pessoa secretariou o pesquisador, registrando dimensões centrais das falas com um duplo intuito: promover a associação dos nomes das participantes aos discursos, mediando a transcrição, e facilitar a análise da reunião, caso não fosse possível transcrevê-la por inteiro antes do encontro subsequente.

\subsection{Procedimentos}




\subsubsection{Construção da análise em ato}

Inicialmente, os procedimentos visaram à constituição do grupo de dentistas em pós-graduação, voluntários para a realização da pesquisa. Devemos ressaltar a facilidade de acesso do pesquisador a entidades de ensino em Odontologia em função de ele desenvolver atividades pedagógicas em "Psicologia voltada à Odontologia" em seu estado.

O primeiro passo para a constituição do grupo supramencionado foi contactar o diretor da entidade de ensino, escolhida pela disponibilidade, para explicar devidamente sobre as bases e os objetivos da referida pesquisa, havendo a autorização da sua parte para a realização do estudo com os pós-graduandos dessa entidade de ensino.

O segundo passo foi submeter o projeto de pesquisa ao comitê de Ética do Instituto de Psicologia da Universidade de São Paulo, que o aprovou.

$O$ terceiro passo foi entrar em contato com os professores coordenadores de diferentes cursos de pós-graduação da entidade de ensino para explicar-lhes o estudo e combinar horários para a visita dos dentistas-alunos em dias de aula para listar os interessados em participar na pesquisa.

O quarto passo foi justamente a visita às salas de aula de diferentes cursos de pós-graduação da entidade de ensino. Após a explicação das condições e particularidades da pesquisa, passávamos uma lista para os voluntários colocarem nome, curso, telefone, email e disponibilidade de dias/horários. Foi salientado que a escolha dos participantes, caso houvesse um número de interessados maior do que dez, tinha como critérios: compatibilidade de dias/horários, heterogeneidade do grupo (representantes de distintos cursos, idades e níveis de experiência) e aceite/confirmação de dez participantes, após contato aleatório por telefone com os interessados com base em dia e horário estabelecidos pelo pesquisador a partir de análise comparativa daqueles disponibilizados pelos voluntários ao trabalho.

Salientemos que a lista foi preenchida por muitos interessados, após visita a dois dos cursos de especialização da entidade de ensino. Primeiro, passamos pelo curso de Endodontia e depois, em outra data, pelo de Ortodontia, conforme cronograma de aulas concedido pelos coordenadores desses respectivos cursos. A escolha desses ramos da Odontologia foi em função de serem aqueles que tinham a 
previsão de atividades de ensino mais próximas ao momento do contato do pesquisador com o corpo docente.

Enfatizamos, porém, que, ao telefone, com os horários $e$ as datas estabelecidos, houve uma redução dos voluntários para oito. Foi agendado, nesse momento, o nosso primeiro encontro. Como tínhamos previsto dez participantes, por acharmos um número significativo para um grupo, considerando eventuais faltas, após o primeiro encontro, incluímos mais duas dentistas. Essas foram do curso de aperfeiçoamento em Dentística.

Destaquemos que, no referido curso, houve três interessados, a partir das datas e horários apresentados, bem como do relato das condições de pesquisa: duas mulheres e um homem. Escolhemos manter a composição de dez participantes, tal qual configurada em nosso projeto, chamando as duas dentistas. Pensamos que ter um único homem entre as participantes poderia não preservar o anonimato de suas falas.

Enfatizemos que, no primeiro contato, as profissionais que participaram da pesquisa assinaram o termo de consentimento livre e esclarecido a respeito dela, com as responsabilidades do pesquisador, a liberdade para as participantes desistirem do estudo e a explicitação de aspectos referentes à investigação. Tal termo de consentimento foi produzido, inspirando-nos nos modelos adotados por Vieira (2006) e Ortiz (2007), com base em necessárias modificações e adaptações nossas.

Destaquemos aqui que, como houve integrantes que só foram ao grupo no segundo encontro, o preenchimento de alguns termos de consentimento livre e esclarecido também ocorreu nesse contato.

Ressaltemos que todos os encontros tiveram seus discursos gravados em áudio, o que foi comunicado e autorizado pelas participantes de acordo com o termo de consentimento supracitado.

O primeiro encontro com as dentistas foi de fundamental importância para este estudo, pois, além do preenchimento do termo de consentimento, nele foi feito o enquadre desta pesquisa: verbalizar o mais livremente possível sobre as relações profissionais com pacientes e acompanhantes, os atendimentos odontológicos nos encontros planejados; número, frequência, horário e duração dos encontros; papel do analista/pesquisador; uso de gravadores; preservação do anonimato das participantes, etc. 
Vale que destaquemos que este primeiro encontro teve um caráter especial em que o pesquisador se apresentou e mencionou os objetivos do trabalho, bem como solicitou que as participantes se apresentassem e mencionassem o porquê de quererem fazer parte do grupo; as demandas foram levantadas.

No segundo encontro, também foi necessária essa dinâmica de apresentação. Foram conhecidas as demandas/expectativas das novas integrantes, bem como houve ratificação do enquadre da pesquisa. A solicitação fundamental, apresentada desde o primeiro encontro, foi de que as participantes falassem o mais livremente possível a respeito das relações com pacientes e acompanhantes, dos atendimentos, da prática profissional.

Tanto nesses, como nos encontros seguintes, priorizamos uma postura acolhedora para com as participantes e deixávamos uma bandeja à disposição delas com água, café e alguns biscoitos, pois algumas vinham às reuniões direto do trabalho.

De nosso lugar, oferecemos às participantes do grupo uma escuta analítica e sabemos quanto essa é construída na formação do psicólogo e psicanalista ao passo que, no campo da instituição Odontologia, parece-nos que tem predominado o sentido da visão. Mais especificamente, posicionamos em uma escuta assentada na Análise Institucional do Discurso. Por meio dela, ouvimos os movimentos de constituição e encaminhamento das relações institucionais grupais.

À medida que as dentistas falavam sobre as relações/os atendimentos na Odontologia, lugares em sua dinâmica eram atribuídos e/ou assumidos no dizer ao profissional e suas práticas, incluindo os professores e a entidade de ensino; aos pacientes; aos acompanhantes; também ao analista e às dentistas integrantes do grupo, pelas participantes, agentes institucionais da Odontologia em pós-graduação. O pesquisador também se posicionava em seu lugar de ouvir/intervir.

Enfatizamos acompanhar possíveis mobilizações nos reconhecimentos e desconhecimentos das relações na tríade dentista-paciente-acompanhante delineadas como cenas e posições institucionais/discursivas em grupo. Puderam ser alçados e/ou analisados também alguns sentidos a partir dos posicionamentos discursivos, desde o primeiro dia e, sobretudo, no decorrer dos encontros.

Ressaltamos que nossa intervenção analítica considerou as repetições, os aspectos geradores de estranhamento, o uso dos tempos e expressões verbais, a estrutura linguística das sentenças, as metáforas, os intervalos, a ironia, o discurso 
indireto, o uso de adjetivos ou sentidos atribuídos, entre outros indicadores discursivos, inspirando-nos na abordagem já desenhada em termos teóricos Em uma postura investigativa/interventiva, ocorreram pontuações/marcações, questionamentos, confrontações; bem como foram adotados recursos discursivos diversos, como espelhamentos, sínteses, reorganizações analíticas, comparações de cenas e/ou dimensões do dizer, apresentação de hipóteses interpretativas dos movimentos discursivos na evolução dos encontros, o que produzia efeitos nas interlocuções em grupo.

Enfatizamos também que, ao nos referirmos à intervenção, não partimos de pressupostos do que seria uma boa relação profissional-paciente-acompanhante na área estudada. Procuramos deixar, no reconhecimento de nossas intenções, em aberto o espectro dos efeitos de nossa análise.

Desse modo, estivemos "ligados" aos acontecimentos discursivos construídos em grupo e ao nosso lugar. Não pensamos em estabelecer posições bem definidas a priori para o pesquisador e as participantes da pesquisa, legitimando a repetição de um fazer psicológico em grupo, muitas vezes pautado no modelo clínico. Os encontros aconteciam, com uma rede de posicionamentos e relações produtores de sentidos na ordem institucional do discurso, sendo feita a análise que nos foi possível em ato, por meio de uma escuta flutuantemente atenta às condições institucionais do discurso e aos efeitos de subjetivação. Procuramos, assim, afastarnos de modelos clássicos de manejo psicológico ou psicanalítico em grupo.

Para tal desenho e animação da intervenção analítica institucional dos discursos realizada, foi central, em nossa estratégia de pensamento, a compreensão da transferência como institucional, já ressaltada no âmbito teórico do nosso método de pesquisa, por meio da qual pudemos pensar nas expectativas das participantes umas para com as outras, com a pesquisa, o pesquisador/analista, como também deste para com as participantes da pesquisa/dentistas no grupo e seu trabalho de doutorado, o que se mostrou no próprio dizer. Não trabalhamos, portanto, à moda clássica, com a noção de transferência como uma presentificação de conflitos infantis reeditados pelas dentistas ("clientela") na relação com o analista/pesquisador.

Se o dito e os sentidos construídos não foram desconsiderados em nossa análise, o dizer e seus movimentos produziram-se como nossa baliza analítica, um 
dizer que, em nossa perspectiva, constituiu(-se) (n)as relações institucionais nos encontros realizados, ímpares, pois singulares.

Em suma, estudamos as relações da/na Odontologia pelo veio da Análise Institucional do Discurso, sendo nossa própria pesquisa, a nosso ver, instituição e produção (inter)institucional.

\subsubsection{Procedimentos de análise da intervenção realizada}

Inicialmente, foram realizadas as transcrições dos discursos dos encontros. Essas transcrições ocorreram nos intervalos entre as reuniões de modo a poder ser feita uma primeira análise do material distanciada da análise em ato, manejando a intervenção do encontro subsequente.

Com o término das reuniões grupais, tal análise foi aprofundada. Com todo o material discursivo transcrito, a perspectiva de análise foi a evolução deste, priorizando os lugares de enunciação em detrimento dos enunciados/conteúdos, sem, contudo, desconsiderá-los.

Salientemos que, para tais momentos analíticos, trabalhamos com os mesmos referenciais e procedimentos da análise em ato, só que em outro nível de distanciamento das cenas e posições discursivas em grupo, bem como sem os recursos interventivos.

Para chegarmos à produção do discurso analítico final, "análise da análise em ato", em nosso aprofundamento analítico, realizamos uma leitura encontro por encontro, texto transcrito por texto transcrito, revendo a análise inicial realizada entre as reuniões grupais. Naquele momento e nesse, emergiram cenas, lugares e dimensões que se destacaram discursivamente.

Tais cenografia e topografia discursivas, com suas nuanças, foram acompanhadas por uma análise institucional do discurso na sequência dos encontros, levando-se em conta os dizeres e suas (possíveis) mobilizações de reconhecimentos/desconhecimentos e consequente configuração de forças.

Houve a consecução, desse modo, de um acompanhamento evolutivo dos seis encontros, analisando os discursos, levando em conta o lugar do pesquisador/analista. Destacamos que, nos procedimentos analíticos, pensamos em 
sujeitos no e do discurso e na dimensão discursiva legitimando modos de relação das odontólogas com suas práticas, os pacientes e acompanhantes.

O "produto analítico final" tem, então, o seguinte formato, com base nas desmontagens e remontagens na fase de análise da intervenção realizada: apresenta encontro por encontro inicialmente por meio de uma síntese analítica da reunião que nomeia as cenas depreendidas e descreve as quatro posições nas interlocuções: do analista/pesquisador, do dentista e de suas práticas, do paciente e do acompanhante. Posteriormente, para cada encontro, são analisadas minuciosamente suas cenas discursivas.

Referente às cenas de cada reunião, ocorrem descrições analíticas do pesquisador, seguidas de demonstrações com citações elucidativas, recortadas da íntegra dos discursos transcritos, contextualizadas, se necessário, com as intervenções, também discursivas, do analista/pesquisador. São acompanhados assim, em seu próprio fluxo, os movimentos institucionais discursivos durante cada encontro e na evolução dos encontros no tocante à visibilidade que as dentistas conferem à relação com os pacientes, acompanhantes e a profissão, o que inclui transferencialmente as posições em contato das dentistas, delas com o analista/pesquisador e vice-versa. Alguns sentidos ou hipóteses também se delineiam nesta nossa análise. Outro ponto que enfatizamos é que, nas citações discursivas, aparecem grifos sinalizadores em dimensões significativas abordadas por nós descritivamente.

Interessou-nos, sobretudo, como as vozes se (re)organizaram nos encontros e no decorrer deles, as estereotipias, os aspectos geradores de estranhamento, os verbos, a forma das sentenças, entre outros indicadores de nossa abordagem analítica. A nossa análise se configurou, portanto, muito mais descritiva do que hermenêutica/interpretativa.

Enfim, a análise da intervenção realizada mostra cenas de uma analítica institucional dos discursos e subjetividades nas relações na Odontologia por meio do recorte estabelecido. Por ocasião da discussão da análise de nossa pesquisaintervenção, ocorrem outros movimentos em que nosso discurso analítico, em seus aspectos mais fundamentais, relaciona-se com trechos discursivos significativos de alguns autores dos capítulos teóricos com os quais refletimos sobre nossa caminhada. Em tal momento, inclusive, é que resgatamos os objetivos e as hipóteses inicialmente formulados para nosso trabalho. 


\section{AS ANÁLISES: CENAS E LUGARES NO DISCURSO DE DENTISTAS ACERCA DE SUAS PRÁTICAS}

Neste capítulo, que se refere às análises sobre a intervenção analítica em ato, comentamos os seis dias de grupo com dentistas. Mencionamos cada um por vez: inicialmente, por meio de uma síntese analítica; posteriormente, através das análises das cenas do encontro.

Criamos códigos para a apresentação do corrente capítulo. A (a maiúsculo em negrito) é a voz do analista/pesquisador em suas análises a respeito da intervenção analítica em ato; em tal momento, a letra do texto segue tamanho e padrão usuais. Os discursos com letra em tamanho menor e recuados concernem à intervenção analítica em ato propriamente dita, sendo que: a) quando a fala é do analista, convencionamos localizá-la entre parênteses, e b) as falas das dentistas aparecem em itálico e com seus nomes fictícios precedendo essas falas ou antecedidas da expressão "grupo", adotada nos momentos em que não identificamos nas transcrições de quem provém a verbalização ou em situações que achamos mais apropriado utilizar tal termo na construção do discurso analítico sobre a intervenção realizada.

As reticências, por sua vez, entre colchetes indicam recortes de falas que fizemos; já as que não possuem tais marcadores sinalizam os intervalos do próprio pensamento do falante. $\mathrm{O}$ código $\mathrm{R}$ representa a abreviatura do nome do analista (Ricardo), quando este é referido pelas dentistas.

Além disso, todos os nomes de professores, locais ou serviços, que pudessem romper o anonimato das participantes, foram transformados em códigos como letra(s), por exemplo, professor X, Wa (referente a uma instituição onde uma dentista trabalha) ou, então, nomes fictícios, como "Céu", representando o serviço onde uma das odontólogas atua. Ressaltemos ainda que mantivemos as repetições de palavras e os vocábulos incompletos presentes no discurso, preservando os desenhos da linguagem.

\subsection{O primeiro dia de grupo}


No primeiro encontro, reconhecemos quatro cenas fundamentais. A primeira cena é o pesquisador demandante; a segunda é do lugar de pesquisador demandante ao de analista de demanda. Denominamos a terceira cena de os lugares dos profissionais, pacientes e acompanhantes no atendimento odontológico. A quarta cena é o retorno do pesquisador demandante.

Sobre o lugar do pesquisador/analista, percebemos que ele se posiciona neste encontro em dois movimentos: ora como pesquisador demandante a instituir as condições de pesquisa, ora como analista das demandas produzidas às dentistas e dos delineamentos das relações na Odontologia. No primeiro posicionamento, a relação configurada é com as participantes do estudo, para garantir a consecução deste; já no segundo, é com as analisandas. Nessa perspectiva, o analista faz investigações, espelhamentos e sínteses. $O$ analista dirige-se às dentistas genericamente e também pelo nome. $\mathrm{Na}$ interlocução, solicita que elas falem das dificuldades. Ele assume uma postura de proximidade para com as integrantes do grupo.

O lugar das dentistas e de suas práticas delineia-se na relação com o pesquisador/analista. Demandas diversas mostram-se presentes: aprendizado, troca de experiências, escuta, visibilidade de situações, o falar sem culpa e o lidar com situações específicas. Há pedidos de confirmação na interlocução. Podemos dizer que há uma transferência institucional de saber: da Odontologia para a Psicologia. A posição atribuída ao analista não é unívoca; é também um pesquisador (de doutorado) e escapa para com ele o termo professor. Também há uma aproximação discursiva por uma dentista do lugar do psicólogo ao do odontólogo no conversar e entrar na vida do outro. A relação dentista-dentista configura-se, na expectativa das odontólogas participantes, como de troca.

O dentista e suas atividades são reconhecidos em movimentos diversos, indicando a construção de dimensões de invisibilidade ao atendimento da clientela (para ela não sofrer?) e do sentido da visão na definição da prática odontológica por meio do dar "uma olhadinha". Nuanças de contextos, singularidades profissionais e a marca da experiência associam-se ao papel do odontólogo. O fazer/agir parece central; surgem expressões como: contornar, ter habilidade e concluir. Os eixos temporalidade e economia emergem na cenografia discursiva, por exemplo: "Sou do tempo [...]" e verbos como valorizar e investir. A imagem do dentista, de uma forma geral, é desenhada enfraquecida; especificamente em relação ao médico. A cadeira 
odontológica delineia-se em alguns momentos como pertencente às profissionais em um movimento de busca de força. Surge menção à autoridade como necessária. Há uma referência das dentistas a si mesmas em algumas situações de modo genérico como "classe". Uma posição queixante predomina nas profissionais. A expressão "medo de dentista" deixa ambíguo de quem é o medo.

O lugar do paciente é marcado por um antagonismo com o posicionamento das dentistas de um modo geral. A criança ocupa espaço no discurso e surgem particularidades atribuídas às diferenças etárias. $O$ medo e a ansiedade são associados à clientela, vendo-se a confiança como construtiva na relação. São produzidas analogias do "medo do dentista" ao temor de ortopedista, bandido e parto. Há distintos reconhecimentos sobre os pacientes nos atendimentos, por exemplo: achar ruim, surpreender, diferentes reações entre as pessoas, diversidade da clientela e paciente amigo. Variações contextuais no respeito, na fidelidade, no modo de tratar o dentista e lidar com o pagamento, entre outros aspectos, são marcadas na dinâmica de posicionamentos à clientela; dimensões socioeconômicas (pacientes carentes ou não), capital e interior são considerados. A prática odontológica não ser geralmente bem vista e a dimensão do mercado nos parecem basais nos delineamentos das relações. Indefinições de sujeito no discurso são percebidas.

O lugar do acompanhante é ambíguo. Ele pode atrapalhar, sobretudo, e/ou facilitar a relação. As profissionais buscam, às vezes, deixar o acompanhante fora das cenas odontológicas? A mãe tem representatividade em exemplos de antagonismos com dentistas, que são agentes institucionais da Odontologia. Delineia-se, muitas vezes, como problemático o binômio mãe (ou acompanhante)criança. O medo é um eixo de associação ao acompanhante. Seu temor é visto sendo transmitido à criança em várias situações.

\section{Primeira cena: o pesquisador demandante}

A: Inicialmente, o pesquisador, à medida que chegam as participantes, acolheas, estabelecendo com elas contato amistoso, breves apresentações e preenchimento de termos de compromisso. Essa fase não é gravada. 
Com a presença de seis dentistas participantes, há a configuração de um círculo, havendo a gravação do encontro em áudio. O lugar do pesquisador se institui no dizer, buscando atribuir e legitimar posições para si mesmo, sua pesquisa e as participantes. A cena discursiva tem começo com o pesquisador falando de seu estudo: "Pessoal, então hoje é um primeiro dia e aí eu queria [...]". Queria marca o caráter de condicionalidade à cena que está a construir. "Certo", "né", "tá" e reticências aparecem sinalizando sua posição de quem solicita confirmação às interlocutoras, as dentistas. No nível imaginário, o lugar do pesquisador configura um vetor de força na posição das participantes na relação. Quem está presente é o pesquisador demandante, não o analista de demanda.

O grupo é identificado pelo pesquisador para sua pesquisa de doutorado. A posição atribuída às dentistas no estudo é localizada: verbalizar sobre o atendimento, as relações na Odontologia, em suas ambiguidades, com liberdade.

"A gente" é uma expressão adotada pelo pesquisador. É uma forma de enunciação em que se coloca no grupo, o que o aproxima das participantes. A relação de expectativa do pesquisador com seu estudo é configurada no dizer. $O$ lugar em que ele se coloca é de facilitar a reflexão sobre as práticas profissionais. "Eu" também emerge. As dimensões do enquadre de pesquisa são delineadas. $O$ respeito à ética de anonimato é afirmado na cena discursiva.

Com o intuito de demonstração, traremos recortes discursivos:

(Pessoal, então hoje é um primeiro dia e aí eu queria conversar com vocês um pouquinho, certo? E... justamente pra colocar a proposta, né? Têm algumas pessoas que não vieram hoje e aí tem um pessoal da Dentística que também está para vir. Aí, a partir do segundo dia, já viria junto com vocês, tá? Então, qual é a ideia deste grupo? Este grupo é justamente assim: minha pesquisa de doutorado, certo? E é justamente um grupo para vocês falarem dos atendimentos, para vocês falarem da relação com o paciente e o acompanhante, do exercício profissional de vocês e do que vocês acham, das coisas que são difíceis, das coisas que são boas. Então é para vocês falarem o mais livremente possível sobre o atendimento, certo? [...] E aí assim: o meu papel aqui no grupo é de facilitador. [...] Eu vou facilitar a discussão sobre as práticas profissionais de vocês. [...] E aí a gente tem este grupo que são seis encontros, cada encontro em torno de uma hora e meia, certo? Ah... além disso, o local sempre vai ser o mesmo lugar, tá? Então a gente vai se encontrar nesta sala, né, sempre. E é... eu acho que chegou alguém aqui... Então, aí ah... o local sempre vai ser esse. E aí a gente combinou quinta-feira de sete e meia às nove, tá? Então esse foi o horário combinado por nós. E ah... esse grupo, a gente tem essas gravações para depois ter transcrição [...] E... e vocês vão ficar com o anonimato preservado [...]) 


\section{Segunda cena: do lugar de pesquisador demandante ao de analista de demanda}

A: Surge um deslizamento do posicionamento do pesquisador demandante ao de analista de demanda. "Queria" e "né" continuam a surgir, delineando um caráter de condicionalidade à cena: depende das participantes. "A gente" é a expressão de onde $o$ analista verbaliza.

O pressuposto do analista é de que a oferta da pesquisa precisa produzir demandas nas odontólogas para as profissionais legitimarem o estudo. Tal mobilização do lugar de pesquisador demandante ao de analista de demanda parece ter como força motriz a atenção analítica ao que as dentistas querem com o grupo. Esse é o acento que garante os reposicionamentos no discurso. Por isso o pedido é que as dentistas se apresentem e falem de suas expectativas. Provavelmente, o analista ser reconhecido como professor, o que ficará claro adiante, alicerce uma suposição de saber dirigido a ele, dando sustentação ao trabalho no plano transferencial.

Produz-se uma imagem de aquecimento. Uma cena discursiva mais calorosa, menos protocolar, instaura-se. Constitui-se um eu, singular, ao analista, relacionado ao poder ver as expectativas/demandas que se desenham nas e das posições das dentistas.

Acompanhemos este exemplo:

( $E$ aí eu queria antes, pra gente poder se aquecer, que a gente fizesse uma rodada, uma rodada para cada um se apresentar, né? Eu sei que muitos se conhecem, mas tem gente que não se conhece tanto. Vocês são da mesma instituição [...] queria que houvesse uma rodada [...] E também por que se dispôs a participar, quais são as expectativas de vocês, o que vocês querem com este grupo, né? [...] Vamos lá fazer esse aquecimento para a gente poder conversar um pouquinho e para eu poder ver as expectativas de vocês.)

Terceira cena: os lugares dos profissionais, pacientes e acompanhantes no atendimento odontológico 
A: Maria é a primeira dentista a falar. É uma jovem profissional com oito meses de formada e em especialização em Ortodontia. Por ela, as relações no grupo são configuradas como de aprendizado e troca de informações, mais especificamente, aprender, quando há interferência do "outro". "Entendeu?" mostra pedido de confirmação por parte da dentista:

Maria: Aprender lidar com certas situações em que outras pessoas interferem, entendeu? Ou trocando informações. Estou atuando no interior em clínica geral e aqui na capital também em duas clínicas: uma clínica particular e uma popular.

A: $O$ analista solicita que ela verbalize acerca das dificuldades:

(Fale um pouco mais assim: quais seriam estas situações que você acha que são mais difíceis ou que você gostaria de lidar mais?)

A: A dentista fala de paciência e, na negativa, de ter mais habilidades. A clientela infantil e seus responsáveis emergem como dificuldades. A mãe é vista atrapalhando. $O$ analista espelha e investiga. As odontólogas, de um modo geral, concordam que a mãe, na maioria das vezes, é um empecilho. Há relativização. medo é atribuído, sobretudo, à acompanhante que o transmite para a criança. Seguem os exemplos:

Maria: Assim, ter mais paciência [...] Tem diversas situações que eu não tenho muitas habili... habilidades.

(Certo. Ter mais paciência com certas situações? E você acha que é mais com... com que tipo de...?)

Maria: Criança.

(Criança? Criança, você acha que é mais difícil?)

Maria: Criança e mãe, os responsáveis. Mãe, eu acho que mãe atrapalha muito $o$ atendimento.

(Você acha que mãe atrapalha?)

Maria: Bastante.

([...] Vocês pensam...?)

Grupo: A maioria das vezes.

(A maioria das vezes?)

Grupo: Depende do dia, não é?

Tem uma: "ai, tou nervosa. Ai, meu Deus do Céu [...]" Está se acabando de chorar [...] criança.

Mas eu acho que têm mães que conseguem passar tranquilidade para a

Tem mãe que é ótima. Tem mãe que é ótima, mas a maioria [...]

Mas a maioria fica com mais medo do que a criança. 
Transmite o medo para a criança.

A: Luara é a segunda dentista a falar. É também uma jovem profissional com oito meses de formada e em especialização em Ortodontia. Ela relaciona sua participação ao fato de ter algumas dificuldades. "Entendeu?" constitui-se como um pedido de confirmação na interlocução com o analista. A diferença de reação das pessoas e a surpresa são marcadas. Trocar e ver são reconhecidos em associação ao poder saber lidar. Na posição da dentista, o vetor de força se constitui na potência do lidar. Medos entre dentistas são sutilmente acenados. "Eu" e "a gente" oscilam nos posicionamentos das odontólogas. Acompanhemos, então, um trecho de seu discurso:

Luara: [...] Eu me dispus a participar, porque eu tenho algumas dificuldades, entendeu? A gente está lidando com pessoas, então cada pessoa tem uma reação diferente e algumas surpreendem a gente. Então assim, como a gente, todo mundo está na mesma situação, né? Dentista profissional e paciente, assim para a gente trocar um pouco, ver assim a reação de uma pessoa, o que ela achou do que eu já passei. Eu vou analisar a reação de outra pessoa e vou poder saber assim: lidar melhor, entendeu? E a gente trocar nossas experiências, os medos.

A: $O$ analista investiga sobre as dificuldades desta segunda dentista. $O$ medo do paciente é posto como "o pior de tudo", independente da dor. Na expressão "medo de dentista", fica ambíguo quem tem medo de quem: o paciente do dentista e/ou vice-versa? As dentistas são posicionadas como "a gente", querendo ajudar a clientela, e esta, em oposição, achando ruim. $O$ desenho que se delineia nos lugares discursivos é de um antagonismo entre profissionais e pacientes:

(O que é que você acha que é mais difícil, Luara, na prática odontológica?)

Luara: Acho que o pior de tudo é que assim: acho que noventa e cinco por cento dos pacientes são muito medrosos. Eles chegam para a gente com muito medo, independente de estar sentindo dor ou não. Acho que, na maioria das vezes, eles chegam para todo mundo e: "olha, sou muito medroso. Eu tenho medo de dentista quanto de ortopedista." Aí já atrapalha a gente. A gente está querendo ajudar a pessoa, mas vê que ela está ali achando ruim, na maioria das vezes.

A: Maria, primeira dentista a se apresentar, reconhece, neste momento, a prática odontológica como não sendo bem vista pela clientela. Configura-se uma imagem de um policial, símbolo de força, com medo de deitar/sentar na cadeira de paciente. $O$ analista mostra surpresa na interlocução:

Maria: Já tive um caso que eu atendi também que era um policial (Riem). Aí ele disse que preferia entrar numa casa cheia de bandidos do que deitar na cadeira de paciente.

(Preferia?)

Maria: Enfrentar uma casa 
(Como é Maria?)

Maria: cheia de bandidos do que sentar na cadeira [...]

(É mesmo?)

A: Luara cita um paciente que preferia a dor de parto, analogia com a Obstetrícia, ao atendimento odontológico. Bianca ratifica a situação de medo da clientela. Há interlocução, na ambiguidade, sobre "o medo do dentista". "Habilidade para contornar" e "ser um pouco psicólogo" mostram pontos de tensão na relação dentista-paciente. A Psicologia é identificada à Odontologia no "conversar" e "entrar na vida." Estamos falando de transferência institucional?

Luara: Já tive paciente que preferia ter outro filho, fazer outro parto, a dor do parto, do que ser, do que ser atendido.

Bianca: Ontem mesmo, eu passei por uma situação com um paciente, no consultório mesmo. [...] E outra: a idade, cinquenta anos [...]

(Então é a questão do "medo do dentista"?)

Grupo: Do medo do dentista, do medo...

(Então vocês estão colocando que... vocês estão colocando tanto o medo do paciente odontológico é uma dificuldade de vocês e também esta questão de lidar com família, com, com mãe?)

Grupo: Tem que ter toda uma habilidade para contornar isso [...] Tem que ser um pouco psicólogo.

(Tem que ser um pouco psicólogo?)

Grupo: Conversar com o paciente e...

Porque muitas vezes mesmo, o paciente chega comigo assim: chega, começa a contar para você da vida dele, o que é que ele faz, não sei o quê e você começa a entrar na vida do paciente também [...]

A: Carla é a terceira dentista a se apresentar. É também uma jovem profissional com oito meses de formada e em especialidade em Ortodontia. Ela refere-se a aprender a lidar com a diversidade da clientela. Emerge uma posição para ela de não saber. Saber lidar (saber prático) e aprender, na relação dentistadentista, a agir são configurados. Segue trecho ilustrativo:

Carla: [...] minhas expectativas é essa assim... aprender a lidar com certos tipos de pacientes mesmo, diversos. Não sei. O paciente vem e... saber lidar com cada situação. $E$ aprender um pouco assim com outras pessoas a poder estar ligada como agir em diversas situações.

A: Manuela é a quarta dentista a se apresentar. Ela é jovem e tem sete anos de formada; faz especialidade em Ortodontia. Ela posiciona-se com diversidade: "eu", "você", "a gente" e "nosso". São reconhecidas invasão do trabalho ao espaço de lazer e falta de comunicação na relação dentista-dentista. Um não lugar para a 
pessoa no profissional e a solidão no papel de odontólogo? Contornar é um verbo que surge associado ao dentista. O grupo é visto como oportunidade de conversar sem culpa, escutar e transmitir, relacionada às situações em que dentistas se acham únicos naquela problemática. Acompanhemos os exemplos:

Manuela: [...] Eu acho que um dos motivos que leva a gente a participar é que, na maioria das vezes, quando a gente se encontra na rua, a gente só fala do nosso trabalho: de dente, de dentista, de paciente, de medo, de aparelho, de material. E esse é um lugar que a gente poderia vir e conversar tudo isso sem culpa, né? Porque, na maioria das vezes, a gente sai para se distrair, mas só encontra com dentista e só fala da nossa profissão. Então esse é um momento que a gente pode falar à vontade da nossa profissão que é feito para isso. E às vezes eu acho que... a Odontologia hoje em dia chegou num ponto tal que a gente não consegue se comunicar com os colegas. Às vezes é experiências que você vivenciou no seu consultório, você acha que só você vivenciou aquilo, você não tem oportunidade de conversar com outro colega e às vezes você já vivenciou e já conseguiu contornar e não consegue passar a sua experiência à frente.

(Hum hum)

Manuela: Fica guardada e esta é uma oportunidade de às vezes a gente escutar e também passar um pouco mais.

(Então você acha que é uma oportunidade de estar trocando?)

Manuela: Informações, experiências e, às vezes, até coisas corriqueiras mesmo que a gente acha, como todas as situações que a gente acha que nós somos os únicos que passamos por aquele problema.

A: $O$ analista posiciona Manuela como quem atua bastante, diferente das dentistas que falaram inicialmente, recém-formadas. Neste lugar atribuído e assumido, ela refere-se à sua trajetória profissional. Indagada pelo analista se ela vê diferenças onde trabalha, desenha a necessidade de mais funcionárias para receber o valor do tratamento no centro da cidade (clientela economicamente mais favorecida):

(Sete anos. Então, você atua bastante?)

Manuela: É. Já trabalhei em interior. Já trabalhei é em convênio. Já trabalhei em clínica popular. Já trabalhei em diversas situações. Hoje em dia atuo nos meus dois consultórios. Tenho um em Y mesmo e outro em Aracaju, no centro de Aracaju.

(E você percebe diferença [...]?)

Manuela: Bastante. Muita diferença. A gente trabalha no centro da cidade e a gente tem é... tem que ter assim... Vou citar duas experiências bem diferentes. Eu trabalho no Sé e consigo trabalhar muito bem com uma atendente só, fazendo papel de atendente, recepcionista e cuidando do consultório. No centro da cidade, eu já não consigo fazer isso. Eu precisei colocar uma recepcionista, porque se não, os pacientes vêm, então fazem o tratamento e na hora de quitar o valor do tratamento, ele, não é? Simplesmente dizem que não vieram preparado e essas, essas coisas. Aí a gente tem muita... 
A: No exemplo abaixo, distinções contextuais são acentuadas: a clientela mais carente é vista com maior fidelidade do ponto de vista financeiro, bem como mais respeitadora; chama a dentista de doutora por ter "a diferença". Conforme percebemos, com as ressonâncias do dizer em grupo, a correlação de forças movimenta-se no imaginário das relações de acordo com o que se enxerga a depender do ambiente.

Configura-se como o paciente trata o dentista. "Não é nem a questão de eu exigir, eu impor" mostra o agenciamento de forças na relação. À clientela do interior é atribuída fidelidade no vínculo. No centro da cidade/capital, a dimensão econômica é reconhecida como não fidelizando a relação. $\mathrm{Na}$ interlocução, é solicitada confirmação:

Manuela: Apesar do pessoal do Sé ser mais carente, eles são mais fiéis, financeiramente falando. E fora a questão de respeito, não é? No Sé, quase todos os meus pacientes me chamam de doutora Manuela. No centro, grande parte da minha... da minha clientela me chama de Manuela, né? Não tem aquela... aquele... a diferença. Não é nem a questão de eu exigir, eu impor. É a questão mesmo da forma do paciente tratar você que é bem diferente.

(Então o modo de se relacionar do paciente com o dentista é diferente a depender do ambiente?)

Manuela: Do ambiente.

(De trabalho?)

Manuela: Exatamente. Diferente. E outra coisa também é que os pacientes de $Y$, que é praticamente considerados de interior, eles são mais fiéis, né? Não é uma coisa que está ali, mas ele está procurando um lugar mais em conta para poder mudar, não? Ele começa o tratamento ali e se ele não tiver condições de terminar com você, ele para o tratamento, mas não muda. E o paciente do centro [da capital] não é assim. Normalmente se ele encontrar uma coisa mais em conta, ele vai atrás.

A: Júlia é a quinta dentista a se apresentar. É uma jovem profissional, com dois anos de formada, em especialização em Ortodontia. Conforme apresentaremos, ela atribui sua participação no grupo vinculada à troca de experiências na relação dentista-dentista. Aprender a lidar com o paciente, seu medo e sua ansiedade delineia-se. Como se observará no extrato, a expressão "e... só" mostra uma ambiguidade: marca uma interrupção do dizer, mas também a solidão do lugar profissional?

Júlia: [...] eu estou participando também para trocar experiências com as colegas de profissão. E só. Estou atuando [...] em A e B, no interior.

Mais adiante, Júlia diz: Eu quero aprender a lidar com o paciente, com o medo dele, né? Com as ansiedades dele também $\underline{\text { e... só. }}$ 
A: Bianca é a sexta dentista a se apresentar. Ela tem mais idade e experiência que as demais odontólogas, faz especialidade em Endodontia e acentua, como mostraremos, o fazer tudo em sua época. Como cobrar e dividir o tempo são dimensões que quer trabalhar. As relações na atualidade se configuram marcadas por cobrança e outra temporalidade? Há referência a contatos com pacientes sem limite e medo:

Bianca: [...] Sou do tempo que se fazia tudo. [...] me dispus a participar, porque, como eu sou do tempo que fazia tudo, nós também não tínhamos assim consciência de como cobrar. Eramos quase que pioneiros, não é? Então esse grupo é pra me ajudar nas minhas dificuldades: como cobrar, como dividir meu tempo, não é? Porque um terço do tempo... eu não tenho limites para os pacientes. A maioria dos meus pacientes chegam, ficam à vontade como... sem medo.

A: Consertar seus defeitos, melhorar e aprender delineiam também sua relação com o analista/grupo. Demandas clínico-pedagógicas na transferência institucional? A idade/o tempo parece fazer com que ela se veja, não sem conflitos, suscitando na clientela ficar à vontade, falar. A relação com esta é imaginada como de amizade e com direito a presente. A relação com a profissão é vista como de satisfação/realização. À clientela, delineada como amiga, não sabe como construir a relação com a moda atual com base em critérios econômicos e temporais? Fazer alguma coisa e satisfazer a clientela são configuradas em sua perspectiva. "Você está doendo" é uma expressão que nos causa estranhamento. A quem se atribui a dor com "você"? Ao dente? Ao paciente? Quem é o sujeito?

Bianca: Então, não sei. Eles começam a falar. Falam da família, do gato, do parente, do filho. Então, sempre tem... Não sei se é da idade ou já a experiência, né? Chegam e começam ficar à vontade. Eles começam a falar de tudo que eles têm para depois dizer o que querem fazer. Então, como foi uma, uma pesquisa com um psicólogo, eu espero consertar os meus, os meus defeitos, onde, onde eu estou precisando melhorar, aprender, como organizar esta questão de tempo. Tenho duas atendentes também, mas mesmo assim ela... não dá vencimento. É complicado.

E meus pacientes são todos meus amigos. Todos. Às vezes, vão lá e não querem terminar o tratamento para ficar: "doutora Bianca..." Sempre vão. Dão presentinhos. Já deixam agendados para três meses, dois meses. Em relação à profissão, eu estou muito satisfeita. Eu realmente me realizo. Mas aí assim: o tempo, a questão de cobrança [...] Não sabia muito como lidar com esta questão de dinheiro. Então a gente se passa muito.

Outro exemplo de Bianca: Não sei chegar um paciente com, com uma cavidadezinha ou com, com um problema e sair fora do jeito que chegou. Eu tenho que fazer alguma coisa. Tenho que satisfazer ele em alguma coisa. Eu acho que o paciente, quando nos procura, ele tem uma expectativa. Ele vai atrás de alguma coisa. Mesmo por isso, eu não atendo convênio, eu não atendo muito por conta disso, porque se o paciente vai te procurar é porque ele está com problema, alguma coisa está incomodando. Agora é você tem uma cariezinha, é você está doendo aqui, e tchau. Aí marco para outra 
consulta [...] Eu não sei fazer isso. Então eu sempre coloco um curativo, eu tiro um raio $x$, eu converso com ele aí, para depois ele voltar [...]

A: Mais especificamente, cobrar e calote surgem no dizer, marcando a dimensão econômica da relação dentista-paciente. "Nossa cadeira" parece emergir como um dispositivo institucional de dentistas, enquanto o atendimento se constitui antes do orçamento ao prejuízo de quem é profissional e o posicionamento da prática odontológica como "uma olhadinha" (consulta inicial sem pagar) pela clientela tensiona o lugar do dentista. Na cenografia do dizer, os verbos que se organizam na locução são desenhados em um enquadramento econômico (valorizar, investir) das relações. Demonstraremos o mencionado com os exemplos:

Maria: Eu tenho dificuldade de cobrar, mas a partir do momento que eu recebi um calote $[\ldots]$

Luara: O problema é que não, o paciente não chega dizendo: "eu quero fazer isso." Ele sabe que tá acontecendo alguma coisa; quando chega, fala: "eu quero fazer uma revisão". E ali você vai dizer para ele o que ele tem para fazer. Primeiro, ah você tem que atender o paciente para depois passar para ele, no caso, o orçamento, né? Vai dizer o que ele tem que fazer. Aí é um constrangimento, porque o paciente já está sentado em nossa cadeira. Assim, praticamente está em atendimento. Aí você vai fazer o paciente se levantar para ir lá pagar ou então acertar, entendeu, sendo que ele já está lá em atendimento? Ou então você vai lá, começa o atendimento e aí depois ele tem que passar lá na recepcionista para pagar e, às vezes, ele vai embora e não paga, entendeu?

Bianca: Consulta é uma coisa que a gente está começando a cobrar agora. Consulta não existia em Odontologia. Era uma olhadinha. E uma olhadinha qualquer um dá.

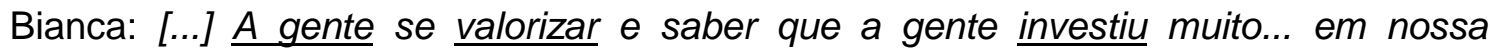
profissão.

(Hum hum)

A: Nesse sentido, constitui-se uma comparação de forças com o médico, que é visto cobrando mais e com uma clientela cooperativa, bem como surge, na profissional experiente, uma imagem de uma transição. Algumas citações mostram tais aspectos:

Manuela: A gente tem muito disso assim: o paciente vai e paga uma consulta com o médico, o médico dá menos que uma olhadinha.

Manuela: $E$ a hora de espera. Se chegar em sua recepção, eles não querem esperar mais do que quinze minutos por a gente. Agora o médico, eu já fui para médico marcado uma hora da tarde e ela chegou quatro horas da tarde. E todo mundo caladinho. Ninguém fala nada. Agora se for na recepção da gente [...]

Bianca: Está havendo uma transição. Hoje há uma transição. Muitos profissionais realmente. Eu assim...

A: A relação dentista-dentista, por sua vez, é vista como de desvalorização, concorrência e desunião. Depreendemos uma imagem enfraquecida do profissional 
ou, no mínimo, predominância de uma posição queixante entre as dentistas. Surgem, entre outros, os seguintes exemplos:

Grupo: É a educação da, da, da população. Todo mundo é condicionado que o dentista arranca dente, que é só isso e mais nada. cobra $[\ldots]$

E os, os profissionais, porque se eu cobro consulta, minha colega vizinha não

Não tem união da classe.

[...] os dentistas estão botando o preço mais baixo, mais baixo, mais baixo, para ficar no local que ele desvaloriza a classe.

A: Bianca tem um posicionamento em que a imagem de seu lugar não é enfraquecida:

Bianca: E tem essa desculpa que tem muito dentista. Eu acho que isso é um absurdo: "porque a profissão está saturada." Toda profissão está saturada. Se for para um profissional, não falta cliente. Não falta.

A: Surge, então, no grupo, que lidar com criança é mais difícil e se constroem sentidos para tal posicionamento. Há, em contraposição, quem prefere atender criança. Há relativizações no dizer. Apresentaremos recortes de algumas das frases elucidativas:

([...] Outro ponto levantado foi em relação ao atendimento de crianças: ter paciência. Maria que trouxe ter mais paciência. Vocês atendem muitas crianças?)

(Respostas sobrepostas)

(E vocês acham que esta questão de ter paciência, lidar com criança é mais difícil?)

Grupo: $\underline{E}$...

Criança birrenta, né?

Eu particularmente, eu gosto de atender criança. Eu até tenho mais paciência com crianças do que com adulto e adolescente.

A: O analista investiga o dizer e ele é posto no lugar de professor (É docente em seu estado). Gostar de atender criança é associado à afinidade desta. Não é uma questão de relação? Tudo indica que não, que é uma questão da "própria criança". Se ela tiver afinidade ou se ela for "ótima"...

(Então, vocês acham que é por quê? Maria trouxe que pra ela lidar com criança é difícil, sobretudo criança birrenta. Luara já está dizendo que, pra ela, ela gosta de atender criança. Vocês acham que essas diferenças vêm de quê?)

Grupo: Professor... eh...eu não sei. Eu não sei dizer qual é a diferença. Isso às vezes a gente... vem da afinidade. Afinidade da própria criança.

Tem criança que é ótima.

Tem criança que é maravilhosa. 
Tem criança que você vê que está fazendo um pouco de manha para chamar atenção para alguma coisa assim que me dá nos nervos.

A: Bianca configura os pais atrapalhando o atendimento, e ela os posicionando fora da cena. As imagens de autoridade para o profissional e de confiança para a clientela são construídas para o fazer odontológico, como vemos no trecho a seguir:

Bianca: [...] Porque eu atendo muito pouco criança, mas têm pais que atrapalham. Eles querem falar pela criança e eu: "e aí, você não fala não?" Eu começo a direcionar minha conversa só pra ela. A conversa é: eu e ele, a criança. Os pais, eu deixo de lado. Então eles começam, eu tenho que adquirir a confiança dele em mim. E aí a gente consegue fazer alguma coisa. Então eu acho que é assim: você deixar bem claro quem é a autoridade ali naquele local. Não adianta ele falar: "mãe..." A mãe não vai fazer nada [...]

A: Há reconhecimento de que há variações na relação dentista-paciente de acordo com a idade da clientela infantil, ou seja, a criança, por algum atributo seu, determina um desequilíbrio de forças na relação com a dentista, tendo em vista a obediência:

Carla: Atendendo criança, eu acho assim que cada idade, pelo que eu já convivi com crianças, que cada idade tem uma forma de você se relacionar com a criança para que a criança obedeça os limites, entendeu? Eu acho assim que assim é certo mostrar nossa autoridade, mas eu percebi que tem criança, de acordo com a idade, que nem mostrando a autoridade, ela obedece.

A: Ressalta-se uma diferença entre as crianças que já foram à escola e aquelas que não. Com a clientela de mais tenra idade, a comunicação é vista como não verbal.

Fazer o atendimento é associado à clientela não ter percepção dele. Com a clientela que não fala, este driblar é reconhecido como difícil e emerge um lugar para o acompanhante, de mediador em potencial, na transmissão de confiança à criança. Os pais podem atrapalhar por insegurança e medo na relação delineada. O dentista localiza-se de modo genérico: "você".

Demonstraremos o referido com citações ilustrativas:

Grupo: É, que são mais maleáveis, que a gente conversando, elas já foram pra escola. "Como foi ir pra escola?" Depois de uma idade, elas já obedecem de certa forma. Obedece [...]

Também não consigo. Também tenho um pouco de dificuldade.

É porque assim, quando a criança é muito pequenininha, a gente não tem como se comunicar muito bem com ela através das palavras, entendeu? Não dá para perguntar: "como é seu nome? Onde você estuda?" Aí conversa sobre desenho: "qual a sua cor preferida?" E aí a gente conta historinha. Aí a gente vai... Cria um vínculo maior com a criança, entendeu? Então ela confia em você já e já começa a brincar e você está lá fazendo o atendimento e ela não percebe. Agora quando ela não tem, ainda não consegue se comunicar dessa forma, aí fica difícil com a criança. Aí a gente precisa do pai que às vezes passa confiança para a criança ou não. Se a mãe ou o pai 
for assim muito inseguros, também tiver com medo, eles ficam ansiosos pela criança, aí às vezes piora e você fica sem saber o que fazer.

A: O "ser artista" é associado de modo particular ao lugar do dentista como um disfarce, a representação de um papel, para algumas dimensões da relação não serem visíveis à clientela e a dentista "tentar contornar". A invisibilidade é constitutiva à prática odontológica? Tal posição é relativizada. Singularidades são associadas ao lugar do profissional. O acompanhamento, do ponto de vista físico, da criança é posto como difícil. Citaremos algumas frases elucidativas:

Grupo: Mas também tem o dia a dia, né? Criança percebe tudo, não é? Você está cansado, estava com problema. Tem que ser um artista, na verdade. Tentar disfarcar para ela não perceber e tentar contornar as coisas, as situações, para ela não perceber.

Eu acho. Têm dias que eu estou bastante assim, cansada, estress... tendo algum tipo, algum estresse. Eu tenho que saber contornar para ela não perceber nada, que houve alguma contrariedade, mas mesmo assim [...]

Você já vê a criança com algum problema, porque você não gosta de atender criança.

Eu saio acabada, com alguns que querem descer, querem subir [...]

A: $O$ analista faz síntese do dizer no grupo com base em sua visibilidade das relações triádicas dentista-paciente-acompanhante. Ressalta os lugares desenhados ao paciente, acompanhante e profissional no discurso:

([...] Então, pensando na clientela [...] têm diferenças de uma criança pequena para uma criança maior. Alguns estão dizendo que gostam de atender criança, não é? Outros estão dizendo que já é mais difícil o atendimento de criança, não é? [...] também em relação ao acompanhante, uma certa dificuldade com a mãe.)

Grupo: É.

(Não é? Bianca trouxe a questão também de cobrar. Não foi, Bianca? E de lidar com o tempo $[\ldots])$

A: Ainda, a clientela à espera é localizada como impaciente. Durante o atendimento, ela esquece o tempo. $O$ antagonismo entre agentes institucionais $\mathrm{e}$ clientela se mostra com expressividade pela "língua rebelde". Peça anatômica que se movimenta na cavidade oral durante os procedimentos odontológicos? Imagem oralizada de resistência no lugar de paciente? O desenho que se cria nos lugares discursivos parece ser de uma tensão de dentistas que querem fazer as suas práticas e pacientes que nem sempre cooperam, o que, inclusive, apresenta implicações temporais ao atendimento odontológico. O paciente é localizado possivelmente como ansioso, com dor e sangramento. Seu lugar de atrapalhar o tratamento é marcado. Isso, enquanto fazer/tratar se constitui objeto institucional da 
Odontologia, e são reconhecidas dimensões de resolução de problemas e vulnerabilidade "da profissão". Produz-se uma analogia com o ginecologista pela implicação da relação de dependência. De quem: do paciente ou do dentista? Fica ambíguo. No tratamento, a dentista quer concluir. Há sinalização de singularidades ao lugar profissional:

Bianca: O paciente, ele, ele marca o horário dele. Então lá fora, eles estão impacientes, como ela mesma falou, né? Para a dentista, é no horário. Ah, tem hora marcada? Mas quando eles entram, eles esquecem, né? Entendeu? Eu já tive paciente de, de ficar preocupado com o horário; quando entra, esquece do tempo. Aí faz: "ah, agora eu entendi porque é que o paciente demora aí. Aí é tranquilo." No outro dia, vem... mais disposto. Mas é... esta questão de tempo é complicada, porque se o paciente está ansioso, está com dor, se tá, se há o sangramento que a gente, né? Um sangramento, uma língua rebelde que... não é? ... Então atrapalha muito o tratamento e ah, agora chegou o seu horário e tal. Não dá. O paciente está ali com uma cavidade aberta, com... né? E a gente tem que resolver o problema, né? E eles já passaram meia hora, botando para fora todos os estresses dele, todo o problema, porque realmente dentista ainda é uma... há temor, porque é uma, uma profissão totalmente vulnerável, né? Dentista, ginecologista. Profissão vulnerável, porque está dependendo do outro radicalmente. Então, ele primeiro tranquiliza, bota tudo pra fora, dizem a queixa dele e tal. Ou, quando não tem uma queixa assim, não é? Que já está em tratamento, mas ele vem falar de família, de filho, para depois a gente poder fazer alguma coisa [...] Eu não gosto de interromper o paciente, quando eu sinto que ele está estressado, tá? Quando ele está com problema, eu... E quando eu começo a fazer meu tratamento, eu quero concluir. Eu não gosto de parar na metade, botar um [...] Não tenho que trabalhar desse jeito. Têm colegas que marca: meia hora é meia hora, uma hora é uma hora. Eu não sei trabalhar desse jeito. Eu não consigo; ainda não consegui. E se for para prejuízo, os meus pacientes, eu não consigo não. Como ela falou, quando a gente faz assim alguma coisa que realmente gosta [...] Porque, quando eu trabalhava, eu enjoava tudo [...] No consultório, passa dor, passa enjoo, passa tudo. Se estiver com dor de cabeça, o que for, quando chego no consultório, passa tudo.

A: Não posse de consultório próprio é vista com incômodo. Em oposição, em clínica popular, a prática é marcada por outra temporalidade: é veloz. Indicadores de generalização surgem relacionados ao cliente e ao dentista. Na clínica popular, produzir constitui ganhar, o que não configura tempo para a relação. Controlar é verbo associado ao dentista que se assujeita? Em outro exemplo, é atribuído ao dentista iniciante não ter liberdade:

Grupo: Não é o meu consultório. É o seu, dele [...] Eu tou falando de ter o meu, entendeu? Não é o meu lugar. $E$ isso que incomoda, entendeu? O lugar [...] Que nem o seu quarto; é seu quarto. Se for para a casa de outra pessoa, não é seu lugar, não é seu ambiente. Têm pessoas que podem preferir [...] Por exemplo, eu trabalhei em clínica popular, né? Desde que me formei. Eu acho que passei uma semana e fui pra clínica popular. Então esse negócio de tempo, hoje em dia eu tenho que me assim... Eu me condicionei à clínica popular. Eu trabalho com muita velocidade. Eu não consigo trabalhar devagar. Mesmo que eu tiver numa clínica que [...] que não é popular, que eu possa ter aquele tempo todo, meia hora, uma hora com o paciente, eu não consigo. Me condicionei à rapidez, porque, na clínica popular, você não tem 
tempo de você esperar o paciente falar qual o problema que você está, porque você tem que produzir, porque se você não produzir, você não ganha, não é? Se você não produzir, você não ganha. Então é aquela velocidade, aquela agonia. Chega pra cá com um paciente, lá vem outro [...] Eu já não tenho esse tempo que você tem de parar, de conversar com o paciente, de escutar o que o paciente tem para falar, entendeu? Às vezes, eles querem falar, eu já estou doida para... controlando para num...

Em outra locução, surge: Eu falo da mesma situação, porque como a gente está iniciando agora, não é viável ter o nosso. Então, a gente tem que se prestar, se escravizar, é. É a palavra certa: é escravidão. Da profissão da gente. É, nós somos escravos. Então a gente tem que se prestar a certas situações pra se dar bem hoje em dia. Iniciar, né? Se dar bem, não, iniciar a vida profissional.

A: Há relativização que, no próprio consultório, surgem outros problemas. No dizer em grupo, do "você" genérico, emerge "eu". Há menção a variáveis contextuais, mostrando dificuldades em distintos ambientes. Uma terceira pessoa é reconhecida como um obstáculo. Algumas exemplificações serão tecidas:

Grupo: Quando a gente chega no nosso consultório, surgem outros problemas.

É isso, é isso que eu quero passar.

Se você chega em uma clínica popular, você não está nem aí se vai faltar [...] No consultório, você torce para que nada disso aconteça. Porque se faltou luva, o problema é seu por mais que você tenha uma atendente. Eu particularmente, têm pessoas que me ajudaram bastante, mas eu não sei delegar funções. Eu estou ali conferindo se a lista de material é aquela ali mesmo, se dá para a gente diminuir alguma coisa. Tem e tem... Eu particularmente sou do tipo assim: eu só sossego naquele mês, quando eu consigo pagar todos os meus funcionários. Se eu não conseguir pagar, eu não estou sossegada. Então surgem outros problemas que na clínica popular você não tem.

Está lá todo mês, todo mês seu salário.

Seu salarinho está lá com sua produção. Não se preocupa em comprar nada. Não se preocupa se o dólar aumentou, se o dólar não aumentou, né? Se o salário aumentou, se o salário não aumentou, né? Não sei, Bianca, não é? Quando a gente começa a trabalhar num lugar que não, não somos mais duas pessoas, já começa uma terceira pessoa. Já começa o disse que me disse, né? Aquele negócio que a funcionária, uma está se escorando na outra e que eh surgem outros problemas. Não vai chegar um lugar; a gente até pode chegar: "ah, é meu consultório. Eu me sinto bem aqui", mas...

\section{Quarta cena: o retorno do pesquisador demandante}

A: Nesta cena, destacamos um reposicionamento do pesquisador demandante, acordando aspectos para legitimar as condições do estudo, como vemos nos trechos discursivos: 
([...] já está na hora de finalizar. Eu queria conversar com vocês algumas coisas. Primeiro, né, combinar com vocês que vão surgir novas pessoas, que vocês integrem essas novas. Topam integrar essas novas pessoas?)

Grupo: Certo.

Tudo bem.

(E a outra coisa é firmar, né, nosso compromisso de se encontrar em mais cinco encontros [...] Então, vocês firmam o compromisso da gente se encontrar toda quintafeira, sete e meia, nestes seis, mais cinco encontros?)

Grupo: Concordo.

Sim.

A: Acertos finais, síntese e despedidas ocorrem.

\subsection{O segundo dia de grupo}

No segundo encontro, reconhecemos quatro cenas fundamentais. A primeira cena é o pesquisador demandante, a segunda é a inserção das novas integrantes. A terceira cena é uma proposta de encaminhamento da discussão em grupo. A quarta cena é a finalização do encontro.

Sobre o lugar do pesquisador/analista, percebemos que este se posiciona neste encontro de forma analítica. Sua posição de pesquisador parece estar mais legitimada. O analista, de um modo geral, escuta/investiga; questiona, espelha, sintetiza, mostra repetições, atribui lugares às dentistas e acompanha os desdobramentos desses posicionamentos. "A gente" é verbalizado por ele que continua a assumir uma postura próxima no contato com as odontólogas, geralmente incluindo-se no grupo. O analista também põe as dentistas a pensarem sobre dimensões específicas, por exemplo, como, no primeiro encontro, solicitou que elas falassem das dificuldades, indaga acerca do que é bom na Odontologia nesse dia.

O lugar das dentistas e de suas práticas é marcante nesse encontro. A relação transferencial que se delineia parece ser, sobretudo, com a posição do analista, não do pesquisador, que "escapa" como "professor". As demandas das novas participantes variam: relacionamento dentista-dentista, ruptura de pensamento, contato e aprendizado, mudança de conduta. Surge em uma dentista 
uma identificação com o lugar de quem faz pesquisa; e em duas profissionais, a afirmação de que elas têm uma relação positiva com a Psicologia. Parece haver menos pedidos de confirmação na interlocução. As dentistas falam com base em vários pronomes: no plural e singular.

Entre outros aspectos, eixos do primeiro encontro são enriquecidos nos desdobramentos dos sentidos. Os efeitos de reconhecimento e desconhecimento continuam produzindo-se como dimensão fundamental das relações na Odontologia, inclusive, surge neste encontro não sentir o corpo durante 0 atendimento numa espécie de fusão/imersão na prática. $O$ contexto do trabalho não apenas emerge marcando com peculiaridades as relações, mas "fala bem alto" no atendimento. Singularidades profissionais e experiência produzem novos sentidos ao papel do odontólogo. Fazer continua a ser depreendido como central às práticas odontológicas. Há menção à "classe" de modo genérico. Os eixos temporalidade e dimensão econômica continuam muito presentes na cenografia discursiva. Instauram-se um antagonismo entre o papel de dentista e ganhar dinheiro, bem como uma espécie de invasão da profissão na vida da pessoa. As imagens de profissionais continuam enfraquecidas, sendo formulada uma demanda de fortalecimento no lugar do dentista e de suas práticas. O medo, a vulnerabilidade e o não saber no lugar de dentistas são reconhecidos; no primeiro encontro, foram acenados sutilmente. Aliás, vulnerabilidade e força, de danificar o paciente, por exemplo, são identificados no lugar do profissional. Surge indefinição de sujeitos ou troca de posições com a clientela. Há deslizamento de sentidos ao termo cobrar: ser cobrado, autocobrar-se. Emerge o próprio dentista obstaculizando a prática, dependendo da situação. No primeiro encontro, pacientes e acompanhantes foram tidos como resistentes. A formação surge associada ao valorizar-se. Impacto na saúde e desgastes são enfatizados. São mencionadas, em função de indagação do analista, dimensões positivas da área.

O lugar do paciente é marcado por um antagonismo ao posicionamento das dentistas, e singularidades são acenadas à clientela, como no primeiro encontro. Desenha-se uma espécie de imagem de luta com a clientela na Odontologia. A criança não é eixo que se delineia muito neste encontro, mas o paciente especial. Surge também a figura do paciente de urgência. A clientela, vista com variações conforme o contexto, constitui-se, em um lapso, como dentição. 
O lugar do acompanhante produz-se pouco neste encontro e é associado à dificuldade, sendo que a mãe se destaca nesse papel. Como exemplo, querer extração surge na referência ao acompanhante.

As dentistas se implicaram mais em seu lugar profissional neste encontro, enquanto, no primeiro dia, predominou uma posição queixante. Também acompanhamos desdobramentos de sentidos em eixos de reconhecimentos do encontro passado e novos matizes analíticos. Pensamos que se relacionam com os efeitos do refletir, das intervenções realizadas e mobilizações com a inserção de novas integrantes no grupo. A nosso ver, as dentistas colocaram-se a falar de suas vulnerabilidades e ensaiaram posições de menor assujeitamento.

\section{Primeira cena: o pesquisador demandante}

A: Com a presença de oito participantes, em círculo, posiciona-se o pesquisador, novamente como demandante. As dentistas que estavam no grupo pela primeira vez e preencheram o termo de compromisso eram duas que tinham faltado ao primeiro encontro e duas que do curso de Dentística foram inseridas. É atribuição das profissionais que falem sobre suas práticas. A posição do pesquisador parece estar mais legitimada do que no primeiro encontro.

Será demonstrado um recorte discursivo da primeira cena:

([...] eu queria já aproveitar para conversar um pouco com vocês e para as pessoas que estão chegando saberem um pouco como é o grupo, certo? Então, inicialmente, eu gostaria de dizer a vocês que é um grupo pra vocês falarem sobre as práticas profissionais, sobre o exercício profissional, e esse grupo é um grupo que tem mais quatro encontros além deste. E a idéia é justamente poder ver os efeitos que surgem quando profissionais da área de Odontologia se encontram pra pensarem sobre essas práticas profissionais. Então, a gente combinou dia de quinta-feira, de sete e meia às nove da noite $[\ldots])$

\section{Segunda cena: a inserção das novas integrantes}


A: O analista, ao inserir as novas integrantes, faz interlocução com as dentistas, retomando o primeiro encontro em que a ênfase foi acerca das demandas das participantes.

Alguns exemplos discursivos do que delineamos serão apresentados:

(Aí eu queria retomar o encontro passado. No encontro passado, cada um se apresentou e falou um pouco das expectativas em relação ao grupo. Todas vocês se conhecem? Quem chegou hoje.)

Grupo: Não.

(Então seria interessante cada uma dizer o nome, tá? Quem veio semana passada dizer o nome.)

(Dizem os nomes)

(Eu sou R, vocês conhecem. Apresentei a proposta para vocês, e, retomando um pouco o encontro passado, as pessoas falaram das expectativas em relação ao grupo. Vários assuntos foram trazidos. Vocês lembram? [...])

A: $O$ analista solicita que as novas integrantes se apresentem e explicitem suas expectativas. O acento é dado à produção das demandas, do querer das odontólogas no grupo.

Dulce, primeira dentista a falar, com mais de quarenta anos, formou-se em 2006 e faz especialização em Endodontia. Ela associa a pesquisa ao termo superestranho. O lugar do pesquisador é visto por ela de forma questionadora, tentando juntar dentistas ou ver o que cada um tem. De modo hesitante, ela localiza os odontólogos como uma classe desunida. A relação dentista-dentista é a tônica de seu dizer. Ela afirma que quis participar para ver se rompe com sua visão.

O analista investiga o pensamento de Dulce e associa seu posicionamento ao que já fora delineado anteriormente no grupo. Bianca desenha um lugar solitário ao dentista. Dulce posiciona sua expectativa como contar com colegas. Cobrar e saber como o paciente é visto emergem em sua demanda. "Né?", reticências e indagações são produzidas.

Acompanhemos o mencionado nos recortes das interlocuções que seguem:

([...] Aí eu queria saber de quem chegou primeiro [...] que se apresentasse e também dissesse as expectativas que vocês têm em relação a esse grupo [...].)

Dulce: [...] Deixe eu falar logo que... Me deu assim uma... Quando você foi lá na [nome da instituição de ensino] apresentar isso pra gente, eu achei superestranho. Eu disse: "pesquisa em relação a isso?" Eu fiquei: "dentistas são uma classe muito desunida"; eu acho, né? Particularmente, eu acho. Eu fiz: "o que é que ele quer com isso?" Eu disse: "que ideia é essa de tentar, né, juntar ou ver o que é que cada um tem?" Eu achei muito estranho.

(Hum) 
Dulce: Aí eu disse... fiquei na expectativa. Eu disse: "eu realmente, eu vou participar para ver se eu quebro um pouco", porque pode ser até preconceito meu, né, de repente, a classe não é assim? Eu que percebo assim. Deve ser um preconceito. Então deve... Já vou quebrar por aí. Vou logo participar.

(Hum hum)

Dulce: Me chamou atenção isso [...]

(Hum hum)

(E aí você pensou em preconceito em relação a...?)

Dulce: Em relação ao próprio dentista, que a gente, eu acho uma classe muito desunida.

(Hum hum. Sei. Isso foi trazido, não foi?)

Bianca: [...] aquela questão de que nós nos trancamos no consultório. Então, de repente, é que a gente não consegue se encontrar, né, e falar dos nossos, dos nossos problemas [...]

Mais adiante o analista indaga: ([...]E qual é a sua expectativa em relação ao grupo? 0 que é que você quer que aconteça no grupo? O que é que você gostaria que fosse refletido, trabalhado no grupo?)

Dulce: Então, primeiro é esse, para vencer um preconceito meu, para que a gente sempre possa contar um profissional com um colega, né? Ou questão de dúvida mesmo, já que todo mundo tem, né? Que a gente sempre está estudando. Ou mesmo assim... Ah, eu não sei co... Eu não sei particularmente. Também eu não sei cobrar. Estou aprendendo no dia a dia, porque tem que cobrar, não é? Tem que manter, né? Aí esse também é o segundo aspecto já, né? E essa interação: como é que eles veem o paciente, como é que eles chegam?

A: Ao falar de sua expectativa para com o grupo, Célia, que tem vários anos de formada e faz aperfeiçoamento em Dentística, posiciona-se numa relação positiva com a Psicologia e enfatiza que está tendo afinidade com criança. Seu lugar no discurso é reticente, com falas quebradas, indagações e vários "né?" "Mas acredito que eu gosto de Psicologia mesmo" parece marcar sua dúvida quanto aos caminhos dos encontros grupais. Estes são desenhados por ela como lugar de contato e aprendizado. Em um duplo vínculo com a proposta, surge nela uma identificação com o lugar do pesquisador por já ter feito pesquisa, encontrando dificuldade com seus participantes, como vemos:

Célia: Veja, quando você chegou lá, né, se apresentando, falando que estava fazendo um trabalho de pesquisa, né? [...] de doutorado e tudo, aí eu achei interessante, porque eu gosto muito da área de Psicologia. Eu acho muito interessante. E eu tô tendo muita afinidade com criança lá no posto, entendeu? Porque lá o meu trabalho... eu estava até conversando com as meninas; às vezes, muita criança... Minha colega, como ela não gosta muito de atender criança. Já está cansada, com toda razão. Aí ela às vezes: "ah, podia até..." Ah, eu atendo. E eu tô assim, tendo uma relação muito boa com criança. Vai ser bom. Vai ser interessante, né? Não sei assim... [...] porque está clareando mais. Eu estou entendendo mais como é que vai ser sua pesquisa, o seu trabalho, tudo. Mas acredito que eu gosto de Psicologia mesmo [...] e vai ser bom, vou 
conhecer pessoas novas, vou... né? [...] Vai debater, aprender coisa nova [...] Não sei. Minha expectativa foi essa mesma de poder ajudar, porque eu fiz uma especialização em Saúde Coletiva e eu me senti muito assim, sabe? Quando eu fui fazer a minha pesquisa, também aí eu senti assim: a gente sente uma certa... As pessoas não ligam muito $[\ldots]$

A: Prosseguindo, Célia delineia seu trabalho no serviço público. Gostar é relacionado à sua profissão. Não se sentir realizada é associado ao salário e às condições de trabalho. O sujeito oscila entre "a gente" e "eu". Sigamos a interlocução abaixo:

Célia: Nunca fiz consultório. Sempre trabalhei em Serviço Público. Adoro! [...] Faço com prazer; agora não me sinto realizada por causa do salário [...]

(Hum hum)

Célia: Então, eu sou frustrada por conta disso. Não é que eu não goste da profissão. Adoro a profissão. Gosto do que faço. Mas não estou satisfeita com o salário. E com a qualidade do trabalho, porque a gente a cada dia que passa está trabalhando... pedindo pelo amor de Deus, venha aqui, porque eu não vivo cada dia que passa.

A: $O$ analista sinaliza que têm surgido repetições no grupo e posteriormente poderá haver o aprofundamento do que se delineia. A expressão em que se localiza é "a gente", inserindo-se no grupo, o que produz um tom de aproximação dele com as dentistas, como vemos em:

(Eu acho que alguns assuntos estão até se repetindo, né, com as novas pessoas? Depois a gente vai poder aprofundar sobre isso.)

A: Mônica, jovem dentista com quatro anos de formada, já especialista em Endodontia e fazendo aperfeiçoamento em Dentística, ao se apresentar, ratifica as dificuldades no serviço público. Sua relação com este contexto parece ambígua. O baixo salário é visto como "o que pega". Ela também marca que gosta de Psicologia. A relação profissional-paciente é posta como demanda de saber e complicada. Por seu lugar singular de "hiperatividade", impacienta-se com situações e não consegue controlar esta sua impaciência, o que a torna visível ao cliente. No dizer, há aproximação de impaciência e ansiedade. Demostraremos o mencionado logo abaixo:

Mônica: Eu trabalho tanto no serviço público, como Célia, e também no consultório. Sei de todas as dificuldades que Célia estava falando. É complicado. Quando ela falou para mim; quando ela falou a questão da desunião da classe, ela me lembrou de um acontecimento [...] Como ela, como Célia falou, o que pega muito é o baixo salário. [...] Assim eu gosto do serviço público, mas me realizo no consultório, que é o que é que eu faço, que é a parte de Endo. Gosto da profissão. [...] Como Célia também, eu adoro a parte de Psicologia. Gostava na época da faculdade. E uma das coisas que me veio na cabeça, quando você veio conversar comigo, foi a questão da relação profissionalpaciente, entendeu? Que é muito complicada! Eu sou muito hiperativa. Eu sou muito elétrica. Quer dizer: têm horas que eu fico impaciente com determinadas coisas e não 
consigo controlar isso em mim. Acaba demonstrando essa minha impaciência, essa minha... ansiedade, até mesmo pro paciente.

A: Em seguida à especificidade sinalizada da dentista, surge um novo eixo neste encontro: os pacientes especiais, abrangendo também hipertensos e diabéticos. O lugar que Ihes é atribuído é diferenciado; a relação com eles é vista como complicada. Tal contato entre agentes institucionais e clientela parece tenso, como vemos no exemplo:

Célia: Pacientes especiais [...] Muito importante também saber tratar: hipertensos, diabéticos... Não é só o especial, né, com [...] mas o hipertenso, o diabético que são pacientes que também, sabe, complicado a relação.

A: Denise apresenta-se. É uma jovem dentista, com alguns meses de formada, que faz especialidade em Endodontia. A sua expectativa é desenhada quanto à relação com a clientela com quem a profissional tem dificuldade. Surge a figura da mãe obstaculizando. Uma relação triádica é complicada: equipe-pacienteacompanhante? A extração é localizada como expectativa materna. A qual perfil de acompanhante se refere? Sua maior dificuldade é posta como a cobrança, termo que se mostra com múltiplos sentidos.

A dificuldade de cobrar à clientela, dimensão econômica, desliza para a problemática da dentista se cobrar demais (dimensão psicológica). Tensão, insônia, preocupação com a clientela são associadas à relação com o paciente de urgência. "Fiquei mais doente" mostra o impacto na saúde da profissional (inexperiente) do contato com a clientela. Em termos do lugar em que a odontóloga se posiciona, este varia: "eu" e "você". Seguem exemplos:

Denise: [...] minha maior expectativa é [...] cada vez mais essa relação com o paciente. Que eu tenho dificuldade. Estava conversando há poucos instantes, com a mãe de um paciente especial, principalmente de, de saber qual é o problema. Dificuldades também em relação a... profissional, quando o paciente entra, principalmente criança com a mãe, que às vezes a mãe quer exigir que você faça determinado procedimento, que você vê que não tem necessidade e que a mãe quer porque quer. Por... um exemplo, extrair um dente e não tem necessidade nenhuma de extração. Dificuldade... Minha maior dificuldade é a cobrança, porque, se eu pudesse, eu não cobrava a ninguém. Falar a verdade. Principalmente no interior que o pessoal é carente. Eu fico... Eu conheço todo mundo. Todos os meus pacientes, eu conheço. Então se eu pudesse, eu não cobrava, não cobrava a ninguém.

Denise: Em todo lugar. É em todo lugar. Aqui também eu tenho dificuldade. Tem um paciente que eu já atendi umas dez vezes que eu não cobrei, que eu não tenho coragem de cobrar. E eu acho que eu nunca vou cobrar; se ele nunca me perguntar, eu nunca vou cobrar. Então eu tenho uma séria dificuldade nisso. De, de... E também eu estou sentindo muita dificuldade que aumentou muito, por exemplo... eu me cobro demais em relação... Eu recebo paciente de urgência. Eu fico tensa, sem dormir. Preocupada se ele está melhor. Minha secretária liga de meia em meia hora, se eu pudesse, para os pacientes, para saber assim... Recebi um paciente essa semana 
com abcesso de dente alveolar em estado gravíssimo. Já tinha tomado... O rosto estava assim: dez vezes já aumentado o tamanho. E eu fiquei tensa a semana toda.

Denise: [...] Fiquei mais doente ainda por causa disso, mas, graças a Deus, ele está ótimo, mas fico muito tensa em relação a tudo e eu não posso ficar assim, porque se não... Como é que eu vou ficar desse jeito? Tudo que eu faço, eu fico tensa assim... saber a recuperação do paciente. Eu sou muito preocupada em relação a isso. Eu acho que eu tenho que mudar um pouco.

A: Carla, também inexperiente, reafirma o posicionamento de Denise. "Horrível isso", insônia e ansiedade são associados ao lugar da profissional. Célia associa ao tempo pequeno de formada da colega. Vemos novos reconhecimentos $e$ desconhecimentos neste encontro:

([...] Denise está falando isso e Carla também?)

Carla: Eu também. Ah, é horrível isso. Eu também fico sem dormir. Eu deito a cabeça e fico pensando: "tenho que dar assistência. Amanhã tenho que ligar." Eu não consigo dormir. Eu queria mudar isso em mim. É horrível. Muita ansiedade. Não sei. É horrível $[\ldots]$

Célia: Você tem quanto tempo de formada?

Carla: Seis meses.

Célia: $A h$ !

A: Denise posiciona-se com dificuldade para estabelecer limites. Em seu dizer, há muitas reticências. Há sinalizações de diferenças no trabalho de acordo com o contexto. A cobrança surge da clientela para com ela. Emerge seu lugar associado a desgaste, querer dar atenção a todos e estar sufocada:

Denise: E também em relação assim, por exemplo, é... eu sinto dificuldade em dizer não. Eu não sei dizer não [...] Então, todo mundo... aquela cobrança assim em cima de $\underline{\text { mim }}$ [...] Então eu estou assim desgastada demais, querendo dar atenção a todo mundo. Saindo em casa seis e meia da manhã; estou saindo dez, onze horas do consultório. Estou assim: muito desgastada. Pouco tempo que tou lá [interior] e tou sem, sem saber o que fazer. Estou sufocada. Já conversei com minha mãe que vou ter que... Não sei. Cresceu... e o pior é que o paciente só quer ser atendido por mim. Num... Eu já falei: "ah, tem outra, outra, outro profissional". Não querem. Não querem, não querem. Muito assim recente. Eu não tô sabendo lidar com essa situação, porque eu abri consultório aqui [...] e, como eu não sou daqui, tinha uma clientela boa, mas assim com um espaçamento de ho... tinha um espaço de horário, marcava de um hora em uma hora paciente, e agora não têm condições. Eu só ia ficar segunda e terça em L, mas já estou segunda, terça, quarta e quinta e não está dando, não está dando. Se eu ficar sexta, sábado e domingo, não dá. Que eu já olhei. Não tem como. E eu já estou sufocada.

Terceira cena: uma proposta de encaminhamento da discussão em grupo 
A: $O$ analista indaga as dentistas sobre uma proposta para refletir no dia, incluindo-se no grupo com "a gente". Uma dúvida é formulada por Célia sobre o lugar do pesquisador. $O$ verbo associado a ele é tentar. $O$ analista deixa o campo livre ao dizer, como se observa nos exemplos abaixo:

([...] Querem trocar experiências, pelo que eu vi no primeiro encontro e nesse. Só que de tudo que foi falado no primeiro encontro e no segundo, vocês estavam no primeiro e ouvindo agora quem está no segundo também, vocês têm algum desses pontos pra a gente poder ir mais hoje? Têm alguma proposta? [...])

Célia: Você vai trabalhar o, o ...? Todos os pontos que a gente elencou aqui, você vai trabalhar na sua pesquisa? Ou você... ou você vai tentar?

(A gente vai, a gente vai trabalhar com o que emergir, com o que surgir.)

Célia: Ah é?

(Isso. Então o que é que vocês gostariam de?)

A: Bianca propõe o fortalecimento do profissional como primeiro passo. "De repente, a nossa fragilidade é o problema maior diante, né?' causa-nos estranhamento. Perante quem? Se, por um lado, há reconhecimento de fragilidade no papel profissional, a solicitação é de fortalecer este. É o que parece surgir como dimensão central a ser acompanhada na transferência de saber: é desenhada uma busca de força às dentistas. O lugar do profissional é a tônica:

Bianca: Não é melhor... Bom... É... tentar num, nem é... assim. Não é melhor tentar... é... fortalecer o profissional primeiro?

(Fortalecer o profissional primeiro?)

Bianca: E aí... pra depois ele poder cobrar e poder é... interagir com os pacientes $e$ com os pais. De repente, a nossa fragilidade é o problema maior diante, né?

A: Com a proposta aceita, cansaço, exigência de muita concentração, desgaste por conta da posição de trabalho e complicação são associados a ser dentista. Excesso de extração é associado à prática no interior. Surge oposição entre desgastante e realização. Satisfação constitui-se ao terminar de fazer? Citemos algumas frases elucidativas:

Grupo: É cansativo.

Exige muito, muita... assim: concentração. É uma coisa que exige muita concentração e... tem aquele desgaste por conta da, da posição... Eu, eu pelo menos sinto a posição de trabalho, porque eu tenho muita dificuldade em ergonomia.

É muito complicado.

E quem trabalha no interior tem muita extração.

É desgastante, mas ao mesmo tempo pra mim é assim... uma realização, porque quando eu acabo de fazer assim é... eu me sinto muito satisfeita. Eu me sinto satisfeita... feliz. 
A: Com Mônica, o verbo gostar surge no passado justificando continuar a ser dentista. Desilusão da escolha por causa das condições de trabalho? Distintamente do lugar do médico de trabalho mais mental, o do dentista é reconhecido por ser psíquico e físico. Ao final do dia, emergem cansaço e não querer fazer mais nada. "Você" é o pronome associado à dentista.

Um eu, singular, constitui-se com Denise. Surge uma imagem de um corpo que, no exceder do trabalho, mostra seus limites ultrapassados. Bianca comenta que elas amam tanto, que esquecem que a profissão é desgastante. A visibilidade do mencionado só surge ao final do dia.

Abaixo, há alguns recortes discursivos para demonstração:

Mônica: É porque, é porque é aquela coisa. Você só continua com o que você gostava. Se você não gostava, você não continua não, como tem muito profissional, dentistas, que já desistiu. Já desistiu, porque... É diferente do dentista pro médico, porque o dentista, você trabalha tanto mentalmente como fisicamente. Já o médico não. Ele trabalha mais mentalmente. Ele está com um receituário ali, está com um não sei o quê, passa a receita e tchau.

Mônica: Desgastante. Você chega muito cansada, quando chega no final do dia. Aquela coisa que você não quer fazer mais nada.

Denise: Eu não tenho vontade de... Eu não pratico nenhum esporte e nem tenho vontade, porque o corpo assim não... não dá, não dá, não tenho disposição.

Bianca: A gente ama tanto, que esquece que ela é desgastante. A gente só nota isso no final do dia.

A: Produz-se com Denise o "não sentir" quando atende (eixo central neste encontro). É como se o corpo parasse. Fome, cansaço, sensações não são percebidos. Fazer e achar tudo ótimo contornam seu atendimento. Ao término é que surge o cansaço. Em casa, só quer deitar. Parece uma fusão ou imersão no trabalho.

Nas interlocuções, sem lanchar e tomar banho, ficar lá o dia todo, não vê a hora passar mostram um (não) lugar para a pessoa do dentista em seu trabalho. $O$ relógio é que, às vezes, sinaliza o limite. Descansar com "os casos todinhos na cabeça" evidencia que o trabalho continua fora do setting odontológico como uma invasão. Alguns exemplos serão apresentados:

Denise: Pelo dia... mesmo. Eu não sinto... Quando eu estou atendendo, eu não sinto fome. Parece que, que... que meu corpo para. Assim eu não sinto sensação de fome. Eu não sinto assim sensação de cansaço. Eu não tenho sensação nenhuma assim. Eu estou ali fazendo, estou achando tudo ótimo. Mas quando diz assim que parou, acabou, que minha secretária... que minha secretária diz "não tem mais ninguém", aí vem parece aquele cansaço todo. Você chega em casa e só quer deitar. 
Luara: Eu imaginava... Eu imaginava: "meu Deus, quando é que eu vou conseguir passar uma tarde inteira sem lanchar?"

Denise: Eu não conseguia imaginar como eu ia passar o dia todo sem tomar banho... que agora eu não estou indo almoçar em casa. É sério. Quando eu fazia... Quando eu estava na faculdade, eu quando tinha aula assim, emendava, eu sempre ia em casa rapidinho para tomar um banho, porque eu não conseguia passar o dia sem tomar banho. E eu não me imaginava... E agora eu fico lá o dia todo. Eu não vejo a hora passar. Eu entro sete; seis e meia, estou lá. Dá dez horas, eu olho assim para o relógio. "Poxa, já dez horas da noite?"

Dulce: E ainda vai descansar com os casos todinhos na cabeça?

A: Surge, em casa, a insônia, a clientela no pensamento. Emerge, no deslizamento associativo, a cobrança dos professores do curso e a autocobrança. Como cobrar a clientela com tanta cobrança? Uma temporalidade muito ocupada desenha-se; uma tensão é delineada no lugar do profissional.

Produzem-se esvaziar e não conseguir fazer nada quando "finda" o trabalho. A lembrança invade o pensar. Das inexperientes? A dimensão do (não) concluir é marcada no dizer. Quão intenso é o impacto do trabalho!

Seguem relatos:

Denise: É... Ainda vou... O pior é isso, porque quando eu chego em casa, não consigo dormir logo, porque ficou pensando: fulano, fulano, fulano, fulano, fulano. Fazendo especialização, ainda estou fazendo aperfeiçoamento em Implante, que eu estou muito desgastada assim, porque você tem que planejar a cirurgia e fazer a cirurgia que eu também... Desgasta muito. E aí fica aquela cobrança dos professores do curso e eu fico assim me cobrando com... queria estar me dedicando mais e estou sem tempo, entendeu? Queria me dedicar mais aos pacientes. Fico assim querendo me dedicar $e$ fico me cobrando e ao mesmo tempo fico assim preocupada, tensa e não consigo dormir bem.

Dulce: Eu passo duas horas e coloco música a respeito do que eu gosto pra... e fico relembrando todos os casos. O pior: sem conseguir fazer nada. Só tirando tudo que eu... esperava concluir. "Fiz isso, fiz aquilo, deixei de fazer isso, amanhã vou fazer isso." Aí fico só lembrando do dia como foi.

A: Com Carla, inexperiente, configura-se também pensar sobre o trabalho em

casa. A profissão marca seu lugar de existir, o que é identificado a "horrível", à causação de ansiedade, como vemos:

Carla: Em casa totalmente. Acaba totalmente. Assim... Quando chega de noite, começa a pensar. Eu queria trabalhar isso em mim. Porque é horrível. É horrível e fico ansiosa, sabe? Fico vendo o paciente triste. Fico ansiosa para começar logo.

A: $O$ analista mostra a ambivalência do vínculo das dentistas com o trabalho e Ihes indaga o que é apaixonante. Tirar dor, acabar de fazer e o paciente sair (término?) satisfeito são acenados:

(Então vocês trouxeram que tem algo de apaixonante na área. É, mas também tem dificuldade. O que é que é apaixonante na Odontologia, né?) 
Denise: Você... Pra mim, o que mais... assim: eu tenho...aquela, aquele cuidado, é quando eu tiro a dor do paciente. Quando o paciente sai satisfeito. Quando você acaba de fazer, e o paciente diga assim: "gostei, foi tudo bom, está tudo ótimo." Isso me satisfaz.

A: Bianca traduz a prática como desafio e arte. Mudar o modo das pessoas encararem a vida mostra uma ação que ultrapassa os contornos das finalidades orais na instituição Odontologia. Chama-nos atenção o verbo com conotações fisionômicas "encarar". A dimensão de transformação estética produz-se. Constituise um lugar à qualidade de vida na área. Surgem em seu dizer pedidos de confirmação com "né?" Efeitos no sorrir e estar de bem com a vida emergem. Vencer destaca-se. Satisfação e realização aparecem ao término relacionados a cumprir o dever. O cansaço físico é sentido depois da cena desafiante em que há uma busca de vitória. O enquadramento parece ser de uma luta.

"Você" é o pronome que se refere ao dentista de modo genérico por meio de um discurso indireto. Querer atingir um fim faz esquecer? Visão em foco? Na ordem dos reconhecimentos, "levar o trabalho para casa" deixa de ser problema com o tempo, a experiência. A dimensão da perda de limites destaca-se em "a gente mistura":

Bianca: Primeiro assim, em minha opinião: é um desafio, né? É um desafio, é uma arte, né? É... Você muda a, a... a maneira das pessoas encarar, encarar a vida. [...] Um canal, a gente também muda a qualidade de vida da pessoa, que está com dor... A estética é impressionante. A pessoa está sem sorrir, de repente está... de bem com a vida. Então isso são desafios, né, que a gente se realiza, né? Passa o dia todinho... está querendo é, é... vencer cada desafio que cada paciente apresenta pra gente. E no final tem aquela: "puxa, cumpri o meu dever, me satisfiz, estou realizada." $E$ aí depois vem o cansaço físico, que a gente não nota quando está nesse desafio.

[...] Você quer atingir um fim. Você esquece, né, as outras coisas? A questão de levar para casa, eu acho que com o tempo a gente vai conseguindo resolver isso, porque... Principalmente... Principalmente quem tem famílias, porque tem a hora do trabalho, tem a hora da família... e tem a hora do seu lazer [...] Às vezes, a gente mistura. Epa, pera aí. Tem que ter... um tempo para cada coisa. Se não... Aí a Odontologia passa... a ser um fardo, né?

A: Célia marca, na negatividade, somatizar, um impacto à saúde de profissionais. Um lugar para a experiência também é depreendido:

Célia: Você não pode... É... A gente não pode... somatizar. Começa a... O que é que dizem os médicos, né, que trabalham em hospitais, essas coisas? A gente não pode somatizar. E com o tempo, vocês que são novas, estão reclamando assim, angustiadas, por conta disso, vai passando. Vão saber da, do... Vão saber do... É... Não sei... administrar direitinho isso e aí vai ficando fácil.

A: Manuela sintetiza os problemas pelo veio econômico. Nesse tom, surgem os colegas que não se valorizam e as desvalorizam. O termo valor está na ordem do 
discurso. Sentidos deslizam-se na dimensão mercadológica. Uma imagem profissional enfraquecida e de assujeitamento (não saber dizer não e cobrar) emerge? Investir na pós-graduação é uma saída?

Manuela: Todos os nossos, os nossos problemas circulam em um ponto só: nós somos mal remunerados [...] Colegas que não se valorizam e por isso desvalorizam a gente. Porque se a gente fosse bem, a gente não precisaria trabalhar tanto, a gente não teria tantos problemas, não é? Se a gente fosse, sei lá, bem remunerado, se a gente tivesse o respeito da classe, a gente não precisaria não saber dizer não. A gente cobraria. Por que é que o médico sabe dizer? [...] Aí a gente precisa investir, tirar de onde a gente não tem para investir em nossas especialidades, pra ver se a gente consegue um retorno [...]

A: $O$ analista investiga e espelha as dimensões de gratificação do exercício profissional. Reconhecimento dos pacientes e resolutividade, entre outros exemplos, são identificados:

(E o que é que gratifica $[\ldots]$ ?)

Manuela: $\underline{O}$ reconhecimento dos pro... dos pacientes.

(Dos pacientes?)

Mônica: A resolução dos casos.

(A resolução dos casos [...]?)

A: Tirar a dor da clientela, ajudar a dentição e a estética (o paciente?), receber presentes são associados à gratificação no trabalho. Olhar, e não ver a restauração, produz satisfação em profissionais? A invisibilidade da cavidade preenchida sustentando o prazer na relação? Exemplos serão mostrados:

Luara: Estar ajudando... Está tirando a dor do paciente. Está ajudando a dentição, a estética, isso.

Mônica: Quando é que a gente faz uma restauração que a gente olha, percebe e a gente não vê nem onde fez a restauração...

Mônica: O paciente olha: "poxa, ficou bem legal" [...]

Denise: Quem trabalha em interior, sabe que os pacientes são muito carinhosos, muito carinhosos. Um mês que eu estou lá, eu já perdi as contas de presentes, de tudo.

A: $O$ analista investiga sobre a variável experiência relacionada anteriormente ao lugar do profissional e de sua prática. Ansiedade e preocupação são vistas mudando com o tempo de formado, conforme os exemplos:

(Em relação à Odontologia e ao papel do dentista [...] eu percebi tanto alguns comentários em relação a quem tem menos tempo de formado. Célia disse: "depois isso passa.")

Denise: Eu acho que isso aí é...

(O que é que passa depois? Quem tem mais tempo de formado, o que é que muda?) 
Célia: Essa ansiedade que elas têm... eu acho... Preocupação [...]

Bianca: E tem também a questão de experiência. Você sabe que aquilo se resolve com um dia, com dois dias e é aquilo mesmo. Não tem o que fazer. Então você vai e descansa, porque você sabe que fez o correto. Mas agora ficam ansiosas, porque não têm experiência.

A: Luara delineia singularidades da clientela. Para Bianca, são exceções que podem assustar. Surgem, nas interlocuções, recorrer à relação dentista-dentista e protelar a consulta nestas situações. As dentistas referem-se à fragilidade de seu lugar profissional. O paciente especial continua a ocupar um lugar no discurso. Não saber emerge no discurso, às vezes associado à dimensão da (não) experiência, na mobilização imaginária das posições nas relações na Odontologia em uma reconfiguração de forças. $O$ analista reorganiza sentidos:

(Como é Luara?)

Luara: Cada pessoa responde de uma forma ao mesmo tipo de tratamento [...]

Bianca: Mas assim o leque não é muito grande. Dá pra você... com o tempo, você... Existem as exceções, mas não são... São exceções. São exceções. Então às vezes você se assusta com um caso ou outro, mas não é a maioria. A maioria vem... com tudo dentro...

Célia: É... mas assim... Eu nunca me aperriei assim demais, não. Eu sempre, quando estou muito aperriada, tem sempre um colega ou outro que a gente gosta...

Grupo: Que ajuda.

Bianca: Aí liga, entendeu? Ou então protela aquela consulta e diz: "olha, venha amanhã"; que chega em casa, vai dar uma lidinha, vai ligar para algum colega.

Denise: Isso que eu estava falando. Como eu sou inexperiente com essa parte de paciente especial em saber os remédios que vai afetar em outros remédios que eu passar, sempre dá uma proteladazinha pra ir lá no livro estudar, acho que isso é normal. Não isso só pra, né, quem formou agora, como também quem tem experiência?

Dulce: Quando eu no interior...

(Célia está colocando que ninguém sabe tudo.)

A: Delineia-se um lugar às dentistas para falar de suas fragilidades, seus estresses, seus medos. As profissionais são posicionadas em vulnerabilidade na relação com a clientela. No fluxo associativo, os lugares de dentista e acompanhantes podem ser de desespero. Uma dentista reconhece que abandonaria a profissão, se um paciente seu morresse em função de seu trabalho. Parece-nos que o atendimento odontológico é pensado na ótica do fazer/tratamento. Há o reconhecimento que nem tudo depende delas; há a implicação do lugar do paciente. Seguem alguns exemplos: 
Dulce: Quando eu comecei no interior, é... chegou muita coisa assim... muito diferente... muito nova. E eu ficava: "meu Deus, será que eu tenho capacidade de avaliar isso?" Chegava paciente em radioterapia, com dor, e eu sabia que tecnicamente não poderia ser feita intervenção nenhuma, mas estava com dor, eu tinha que tirar da dor. Aí eu fazia o quê? [...] Já tinha feito toda anamnese, remédio que já tinha... tudo. Disse: "o que é que eu vou fazer mais aqui? Ela não vai mais sentir dor, então." Mas tava já sentindo [...]

Denise: $E u$, eu, eu tive um paciente [...] O lábio dele estava aqui assim, muito... Eu nunca vi em toda minha vida, assim uma coisa daquela e eu fiquei assim desesperada, o pai desesperado [...] Minha sorte é que o posto é pertinho do meu consultório. Liguei para um amigo meu que é enfermeiro lá. Ele correu lá. Aí, saindo lá, ele já foi pro posto e aí tomou anti... antibiótico injetável, mandei uma prescrição. Aí sumiu. Passou uma semana sumido. Eu fiquei esta semana toda tensa, preocupada. Eu disse: "não. Morrer lá, eu não sei." E acredito que... se ele, se algum paciente morrer, eu deixo a minha profissão, porque eu vou ficar frustrada pro resto da vida, não é?

Luara: [...] Uma coisa que me surgiu. Assim, um paciente que chega nesse estado no seu consultório, eu já paro e eu penso: como é que uma pessoa deixa... esta situação, chega num estado desse, entendeu? Você tem a sua parte. Você faz o seu trabalho. Fica preocupado se fez tudo certinho. Mas você também tem que pensar que o paciente põe em risco em relação à saúde dele.

A: O analista é chamado de professor na dinâmica transferencial. É reiterado que às dentistas cabe uma parte:

Grupo: É professor...

Dulce: Mas se a gente for pensar assim...

Luara: Você não vai deixar de fazer a sua parte. Você vai fazer o melhor que você puder.

Dulce: Oh, o que chega de paciente...

A: $\mathrm{O}$ analista investiga o modo de as dentistas lidarem com a possibilidade de morte da clientela. Dificuldades se mostram. Há uma relativização nas posições discursivas: o lugar do médico é visto como problemático, diferente do habitual, conforme as falas:

([...] Você disse, Denise, que abandonaria a profissão se o paciente morresse?)

Denise: Ave Maria, eu ia ficar louca...

(Aí Manuela disse que não é por aí.)

Manuela: É né? Já pensou os médicos?

Denise: É... É... Por isso que eu digo todo dia: a, a profissão que eu nunca daria para ser era médica.

A: O analista refere-se, no deslizamento de sentido, à cobrança das dentistas. Há o posicionamento de que elas lidam com o que é aparentemente simples, mas 
tem o poder de matar. O analista indaga as profissionais da dificuldade da situação, o que é confirmado:

(Vocês estão falando da cobrança do dentista em relação à sua prática. Isso é muito forte?)

Denise: Para mim, é.

Manuela: É... porque a gente, a gente lida com uma coisa simples. A gente vai fazer uma restauração...

Grupo: Aparentemente.

Manuela: [...] pode matar.

Dulce: Eu acho aparentemente essa [...]

(Isso é difícil? Todos acham difícil?)

Grupo: É. Muito.

A: Não saber é uma forma de evitar sofrimento? De um modo interrogativo, o verbo pagar é associado à dentista. Um termo econômico que surge na subversão dos lugares discursivos entre profissional e clientela? Seguem trechos discursivos:

Célia: Ichi, não quero nem saber dessas coisas.

Mônica: A dentista vai pagar por quê?

A: Nuança produz-se à correlação de forças no contato dentista-paciente: a clientela pode omitir ou mentir. Seguem exemplos:

Mônica: [...] Se a paciente tivesse re... relatado que ela tinha problema de saúde, que ela tinha leucemia. No caso, do paciente, ou do dentista, teria solicitado qual a parte de antibiótico, passado antibiótico, mas como não sabia... Paciente, perguntou se estava com estado de saúde normal? Está. Paciente escutou? [...]

Denise: Mas o paciente omite muito, R. Mente.

A: Sobre o lugar do dentista, querer sempre o sucesso e frustrar-se com a falha emergem. Célia posiciona-se ampliando para todas as profissões algumas condições. Ter que saber lidar e trabalhar configura-se. A cobrança, cada vez maior, das dentistas é marcada. "A gente", "você" e "eu" são termos que se referem ao lugar do dentista. Demonstraremos com algumas citações abaixo:

Dulce: Querer sempre o sucesso, que os pacientes estejam...

Mônica: Você se frustra quando alguma coisa dá errada.

Célia: Eu acho que toda profissão, esse trabalho com, com... assim, com responsabilidade, com compromisso, com ética [...] Você... tem que saber lidar. Tem que saber trabalhar. E aí a gente cada vez se cobra mais; que a gente quer a perfeição.

Célia: Você lida com as vidas. 
A: Manuela define um dentista: ansioso, com um monte de tralha, guerreiro, necessidade de estar se especializando continuamente. A partir do questionamento do analista, há visibilidade de outras possibilidades ao profissional da Odontologia:

Manuela: [...] se ele é ansioso, se ele anda com um monte de tralha, né? Se, se... é... ele é uma pessoa assim... que... está ali na profissão, porque é um guerreiro. Se ele sabe que aquilo ali [...] se eu for citando assim... uma pessoa ansiosa que trabalha numa instituição, porque ama, que vive com tralha de cima é pra baixo, que vê a necessidade de, de estar se, se especializando a todo momento, você vai identificar: é um dentista.

(Manuela está definindo o dentista?)

Bianca: É um dentista.

(É um dentista, Bianca?)

Bianca: Porque têm outros tipos de dentistas.

(Sobreposição de vozes e risadas)

A: Com Mônica, surge a cobrança sobre o número de atendimentos no posto. Produtividade? Célia marca que não faz "isso". É desenhada uma situação do profissional que não põe o paciente na cadeira para olhar. Delineia-se o próprio dentista obstaculizando a prática odontológica. No serviço público? Percebemos que as odontólogas estão bem implicadas analiticamente. Falta de atendente e material são reconhecidos no setting mencionado. Apresentaremos interlocuções:

Mônica: Porque eu fico indignada, quando eu chego no, no posto e um pessoal olha para mim: "ah, por que... atende tão pouco?" Eu atendo dezesseis numa manhã.

Grupo: É pouco?

É pouco?

Mônica: Porque o dentista do dia da minha folga atende trinta.

Denise: Ah, porque ele atende... senta na cadeira.

Mônica: Sabe como é que ele atende trinta? O paciente chega pra ele [...] "Vou fazer uma cirurgia." "Ah, seu dente está inflamado."

Célia: Eu já trabalhei em posto que é a mesma coisa. Eu não faço isso lá [...] que são todos os atendimentos mais as urgências. Eu não faço isso, mas não faço mesmo, porque eu não tenho condições. Já teve colega meu que atendeu assim... sabe, paciente da urgência? Sentadinho do seu lado. Não bota na cadeira para olhar, não. "Ah, está com dor de dente. Está inchado" [...]

Denise: Eu já vi é relatarem que tem dentista que quebra a caneta, né? Corta, corta o, o, a mangueirinha do equipo pra, pra dizer que está quebrado e não...

Célia: [...] atendente não vai, porque ele também não faz nada, entendeu?

Denise: Que está faltando material, né? 
A: O analista espelha dimensões do dizer e indaga se é particularidade do local. Da posição atribuída às dentistas, sentidos diversos configuram-se: não saber, para além do estado, por exemplo. Dulce apresenta diferenças contextuais não pela desvalorização do dentista, mas por a Odontologia ser cara no exterior com um descuido da clientela por isso. Tais aspectos podem ser depreendidos no recorte de interlocuções:

(Agora outro ponto... é... Agora outro ponto que vocês colocaram, né? Várias pessoas assim [...] Foi esse de, de repente... eh... "há uma desvalorização, é mal remunerado, os colegas... às vezes... têm uma série de questões", né? [...] Vocês acham que... esses aspectos têm a ver com a Odontologia de Sergipe? Daqui de Sergipe ou a Odontologia como um todo?)

Denise: Eu não... Eu não sei assim... Não sei dizer.

Mônica: [...] Quando eu vou pra Salvador, todo mundo fala a mesma coisa [...]

Dulce: É uma situação de mundo. Não é só de Brasil, não.

(Não é só de Brasil. É de mundo.)

Dulce: Aí o italiano [...] "na Itália eu não consigo fazer esse tratamento, porque lá é muito caro e aqui [...] me indicaram a senhora" [...] Assim, aquilo tudo pretinho mesmo [...]

A: O analista é chamado de professor, o que repete seu lugar transferencial sustentando a análise institucional do discurso em grupo:

Carla: Eu tenho uma amiga que mora na França. Ela me disse: "Carla, aqui é horrível." Porque, professor, toda bonitinha, quando dá um sorriso, é horrível; porque tudo é muito caro.

A: $O$ analista indaga como elas podem mudar a situação delineada em sua profissão e para si. Surge que todo mundo desvaloriza a Odontologia. Valorizar-se por meio do estudo é enfatizado.

Com dentistas posicionadas a pensarem sobre mudanças, surgem uma autoimplicação das profissionais e o verbo tentar. A ambivalência com a profissão mostra-se pela dimensão econômica. Produz-se um antagonismo entre ser dentista, o que gera satisfação, e ganhar dinheiro.

Acompanhemos os exemplos:

([...] têm questões que têm a ver com a Odontologia e o profissional. Como vocês podem mudar, então? A prática de vocês? [...])

Bianca: [...] Eu acho que, que, que nós, dentistas, primeiro nós nos desvalorizamos [...] Os médicos nos desvalorizam. Os pacientes nos desvalorizam. Todo mundo está desvalorizan... desvaloriza a Odontologia [...] porque se a gente está estudando, está fazendo... é porque nós estamos nos valorizando. Por isso que eu digo que, que a Odontologia é apaixonante e é uma realização pessoal. Porque... eu não espero valorizar a, a valorização de ninguém. Eu faço por mim [...] mas eu não quero viver como mercadoria, não. Eu quero tentar. [...] 
Mais adiante Dulce diz: Trabalhar e correr atrás de dinheiro é difícil.

Mônica: $E$.

Dulce: Ter satisfação, atender, mas saber que tem que pagar conta.

Mônica: É complicado.

Dulce: Ui, é complicado.

\section{Quarta cena: a finalização do encontro}

A: $O$ analista anuncia a finalização do encontro, deixando as dentistas com uma pergunta. A tônica é: constituem-se como sujeitos nas práticas? Ele adota a propósito o verbo poder e o relaciona à Odontologia, tomando um termo que escuta no grupo. Célia posiciona-se querendo (podendo?) falar naquele momento. As outras dentistas Ihe dão este assento. Célia não quer que as colegas novas a vejam como pessimista. Surge a decepção com a profissão na mescla de suas condições constitutivas, entre as quais o lugar do profissional, a gestão e os órgãos de classe, como vemos no trecho discursivo:

(Nós já estamos no horário, finalizando. Vou deixar vocês com uma pergunta: o que vocês podem fazer em relação à Odontologia? Vocês trouxeram vários aspectos: a questão econômica...)

Célia: [...] Você quer que responda agora ou na próxima?

(Não)

Célia: Posso falar?

(Vou deixar essa questão pra vocês.)

Célia: Na próxima... Eu posso falar um pouquinho?

(Pode.)

Grupo: $\underline{P o d e, ~} R$.

Pode, $R$.

Pode, $R$.

Célia: [...] eu queria terminar até no ponto para as meninas não se sentirem assim... que eu estou assim tão pessimista. Não estou, não! Mas eu estou assim: veja bem, eu estou meio decepcionada com a profissão pelos nossos órgãos de classe. Mas é uma culpa que eu sei que uma parcela é minha. Eu fiquei, né? Eu não, não... Não corri atrás, né? [...] Pior é você estar num órgão, numa gestão, né? [...] 
A: O analista busca finalizar o encontro. Várias dentistas continuam a falar. Denise sinaliza que está mais tranquila. $O$ analista recoloca sua indagação. Bianca atribui a si e às outras dentistas saber quem são e seus limites, ressaltando o fazer. Dulce associa o dentista à mania de perfeição. Há, entre outros aspectos, a comparação com a Educação, como vemos no seguinte recorte discursivo:

(Então, têm vários aspectos a serem refletidos aqui no grupo. Por isso justamente que a gente combinou de ter mais quatro encontros pra é... poder...)

Denise: Mas eu já... eu já gostei, que eu já, eu já estou me sentindo mais tranquila. Manuela já deu umas chamadas em mim. Eu olhei... que eu tenho que me conscientizar, né, Manuela, que estou fazendo meu papel [...]?

Manuela: É.

(Eu deixo vocês com esta questão: $\underline{0}$ que vocês podem fazer em relação à Odontologia?)

Bianca: A gente precisa saber quem nós somos e assim nossas limitacões. $E$ assumir o nosso papel. Fazer o que consegue. Não... Não adianta você... querer fazer mais do que consegue. Se eu não consigo resolver um caso, tem um buco, tem um odontopediatra que tem que...

Dulce: $O$ dentista tem mania de perfeição, né?

Bianca: Quer fazer tudo? [...]

Dulce: É a perfeição em pessoa.

Célia: Aí, veja: a gente levantar a bandeira do grupo, do colega, como é uma classe. Eu acho... A gente fala assim... E vocês colocam... que a classe de Odontologia é desunida, mas as outras também são, viu, gente?

(Sobreposição de vozes)

Célia: Eu acho que hoje em dia, que hoje em dia está unida é Educação. Educação, eu acho que são muito unidos.

Dulce: Educação são unidos?

Célia: Eu acho.

Grupo: Eles sempre estão, eles sempre estão reivindicando os direitos deles.

A: No movimento grupal, Célia transforma a indagação do analista em exclamação, mobilizando lugares discursivos: "a Odontologia que devia fazer por mim!" Se, no dito, parece que está na passividade, na subversão do questionamento, mostra-se como sujeito que resiste às condições das práticas odontológicas. Mobilizações nas relações imaginárias com efeitos de subjetivação na reconfiguração de forças? O analista recoloca sua indagação na perspectiva da reorganização de sentidos de Célia, legitimando seu dizer. Finaliza-se o segundo encontro:

Célia: A Odontologia que devia fazer por mim! 
(A Odontologia que devia fazer por você, Célia?)

(Então, o que a Odontologia pode fazer também por você?)

(Despedidas. Ficam conversando entre elas.)

\subsection{O terceiro dia de grupo}

Reconhecemos três cenas centrais neste encontro. A primeira é resgaste de dimensões transcorridas. A segunda delineia-se como as dentistas falam da profissão, dos pacientes e acompanhantes. A terceira cena é o fechamento do encontro.

Sobre o lugar do pesquisador/analista, percebemos que ele se localiza neste encontro bem assentado em uma posição analítica. Sua postura é de investigação/intervenção. $O$ analista movimenta posições cristalizadas, questiona, espelha, acompanha efeitos nos reconhecimentos/desconhecimentos e mostra dimensões com base no fluxo associativo das dentistas, na análise prévia dos primeiros encontros, entre outros aspectos. Ele pergunta, por exemplo, a respeito das facilidades na Odontologia, pois as dentistas tinham falado, sobretudo, das dificuldades, e aprofunda investigação sobre dimensões contextuais nos atendimentos odontológicos, aspecto delineado anteriormente. Ele é, em um momento, chamado de professor; a Educação produz sentidos na cenografia discursiva.

No lugar das dentistas e de suas práticas, há uma demanda, na transferência, de fortalecimento da posição profissional. Pedidos de confirmação são menos frequentes do que antes. Dimensões que surgiram em outros encontros são ampliadas; surgem novos eixos de análise. Algumas relativizações se produzem, mostrando mobilizações nas posições discursivas. As dentistas colocam-se como "a gente", "você" e também no "eu" singular. Emerge um antagonismo entre passado e presente; este parece identificado com a desilusão.

A Odontologia é relacionada a isolamento, desunião, começo, entre outros aspectos. A associação entre ser dentista e desvalorização é recorrente. São reconhecidas relações e/ou condições desfavoráveis de trabalho e remuneração. As profissionais sofrem pelo contexto? A profissão, vista diferenciada deste, é 
associada a atributo positivo. Delineia-se um lugar para a formação: de valorização de si, investir. O profissional é configurado como mercadoria nos abusos do mercado com implicações para sua qualidade de vida. A dimensão econômica surge crivando as relações e as práticas na Odontologia; um posicionamento político emerge sustentando uma possível transformação.

O feminino e a juventude delineiam-se na produção de sentidos. As dentistas parecem oscilar entre uma posição queixante e um lugar político e educador de não se submeter, inclusive na resistência producente ao contexto. Lutar, unir-se e valorizar-se surgem na perspectiva de fortalecimento profissional. Os dentistas são vistos com status, mas com desvantagens diversas. Quem manda ou domina parece uma tônica nas relações na Odontologia. Diferentes perfis são depreendidos do lugar do profissional. Disfarçar e "fechar os olhos" mostram tentativas de invisibilidade de alguns sombreados dos atendimentos odontológicos. Prevenção e educação constituem-se como possibilidades na Odontologia. Mesmo assim, o tratamento nos parece, sobretudo, o objeto institucional na área. Singularidades marcam os posicionamentos das profissionais.

O lugar do paciente é de medo ao chegar (dimensão psicológica) e não querer pagar (dimensão econômica). Há representação dele em antagonismo para com as dentistas. Instaura-se uma relação entre educador e educando; também a prevenção emerge marcando uma posição ao cliente distinta de ser alvo do tratamento odontológico. A prevenção parece surgir de modo ambivalente, ameaçando a posição do tratamento como objeto institucional da Odontologia. Diferenças contextuais e uma comparação com os pacientes dos médicos continuam a produzir sentidos ao lugar da clientela. É desenhado o paciente com expectativa de extração em oposição ao lugar de quem é profissional da área. De quais clientes as dentistas falam? Daqueles com um nível educacional menos favorecido? De um modo geral, há ampliação de ângulos para o que já tinha sido mencionado em outros encontros. O novo é a relação com a clientela delinear-se no plano pedagógico. Também surge uma imagem do paciente como um todo.

O lugar do acompanhante é associado à criança. A imagem da mãe continua a destacar-se. O acompanhante surge no lugar de empecilho constantemente, fundindo-se com o paciente, amedrontando mais do que o próprio dentista. Sentidos particulares são construídos. Quem acompanha o paciente pode ser visto como 
mediador da relação deste com o dentista em algumas situações. Não encontramos mobilizações significativas neste lugar neste encontro.

De um modo geral, movimentos foram percebidos nas posições de dentistas, suas práticas e pacientes com a ampliação de reconhecimentos em eixos que surgiram nos encontros passados, bem como a emergência de novos posicionamentos discursivos. Destacamos também que alguns eixos anteriormente presentes não reapareceram neste encontro. A imagem de uma relação comercial constitui-se com nitidez, realçando o antagonismo entre dentista e paciente no plano econômico.

\section{Primeira cena: resgate de dimensões transcorridas}

A: A primeira cena é do analista, em círculo com oito odontólogas, iniciando o terceiro encontro, retomando dimensões transcorridas. $O$ analista recorre à expressão "a gente", de modo intencional, como estratégia de aproximação sua no contato com as dentistas.

O analista assinala que percebeu ter sido construído um vínculo entre as odontólogas e lhes solicita sugestão de por onde começar o presente encontro; alternativamente, ele indaga sobre o que as dentistas têm pensado em decorrência das reuniões. Ao fim de sua verbalização, apresenta o que faz eco ("Vocês lembram como a gente parou?"):

([...] no segundo encontro mais especificamente, vocês terminaram refletindo sobre a Odontologia, pensando até em fortalecer o papel do dentista, né? Que foi até uma sugestão sua pra gente começar pelo dentista para pensar as questões que têm a ver com a Odontologia e com o dentista [...] eu percebi que ao final do segundo encontro, vocês pareciam mais gregárias, mais unidas [...] Então, hoje, a gente vai dar continuidade à reflexão sobre as práticas odontológicas. E aí eu queria saber, né, se alguém gostaria de sugerir por onde queria começar a pensar sobre essas práticas odontológicas ou o que essas ideias que vocês estão trocando aqui têm feito vocês pensarem fora daqui, né? Queria saber se tem alguma sugestão de por onde começar. O que é que vocês acham? Vocês lembram como a gente parou? Como foi?)

Segunda cena: as dentistas falam da profissão, dos pacientes e acompanhantes 
A: A segunda cena inicia-se onde parou o segundo encontro. Mônica é a dentista que começa a falar, reorganizando ao seu modo a indagação formulada no segundo dia pelo analista, acrescentando o verbo "melhorar". "Poderia" marca a cena com condicionalidade. "A gente" é o lugar genérico no qual a dentista se coloca, e as reticências parecem indicar possivelmente hesitação quanto ao que fazer diante de suas queixas:

Mônica: Você deixou uma pergunta para a gente saber a resposta nesse próximo encontro. Você perguntou como é que a gente... o que é que a gente poderia fazer para melhorar... a profissão da gente. Acho que tem que começar por aí.

A: Seguindo o tom de abertura desta segunda cena, o analista faz espelhamento do dizer e sinaliza que predominaram as verbalizações das dentistas sobre as dificuldades em relação às facilidades na Odontologia. Ele indaga as odontólogas sobre estas últimas:

(Poderia começar por aí: o que pode fazer para melhorar a profissão de vocês. Eu percebi, inclusive, que vocês falaram muito das dificuldades. Vocês também falaram que é uma área apaixonante, mas não sei se foi impressão minha, mas me pareceu que as dificuldades predominaram naquele momento de verbalização de vocês [...] Têm dificuldades, mas o que é que existe de facilidades? O que é que vocês acham?)

A: Bianca fala do passado: o início é associado ao apaixonamento e, então, surgem dificuldades. O sujeito oscila entre "eu" e "a gente". Há pedidos de confirmação à compreensão do analista. A Odontologia é relacionada a isolamento, desunião, classe muito pequena e à gente estar começando ainda. A odontóloga parece acenar para uma posição de (des)ilusão quanto à profissão. Surge um lugar para a juventude de se valorizar:

Bianca: Eu acho assim que, que a Odontologia realmente é apaixonante. Então, a gente entra bastante apaixonada, mas tem essas dificuldades todas. Mas eu ainda não perdi a ilusão, não perdi o entusiasmo; eu ainda não perdi, entendeu? Têm muitas pessoas que perderam. E... eu acho que porque a gente fica muito trancado, daí essa desunião, daí a gente achar que a Odontologia é desunida. Mas também a Odontologia é uma classe muito pequena e todas essas classes que são grandes hoje, foram pequenas. Então... existe também esse problema. Eu acho assim que, que a gente ainda tá começando. Eu ainda acho. Ainda é uma classe pequena [...]

Bianca: A turma é... Essa turma jovem é que tem que se valorizar, né? É que, que...

A: A (des)valorização circula no discurso em muitos exemplos. Com Célia, surge a justificativa de que seu entusiasmo foi perdido por causa do contexto, não pelo ato da profissão. Há comparações com o médico e outros profissionais. Uma imagem de correr atrás, não de acomodação, parece configurar-se para valorizar a profissão e subir na hierarquia. Surge pedido de confirmação no dizer. 
Nas interlocuções, parece ocorrer uma busca de fortalecimento das dentistas por meio de uma implicação política, uma perspectiva de mobilização da correlação de forças no contato de profissionais com sua profissão. Dimensões econômicas são ressaltadas:

Célia: Eu acho que a gente... Eu, eu, eu perdi o entusiasmo na verdade. Ela disse que não perdeu. Eu não perdi pelo ato do, da profissão, mas eu perdi pelo contexto, né? Porque eu não faço consultório. Eu estou numa linha diferente de vocês. Só faço serviço público. E aí a gente vê assim: a profissão desvalorizada [...] Então acho que a nossa profissão, a gente ainda não levantou a, a bandeira enquanto instituição, enquanto profissão mesmo para valorizar. Por quê? O que é que a gente dizia antes: que o enfermeiro era su... era submisso ao médico. Hoje não. Você vê que a classe está se valorizando e está cada vez mais subindo. A mesma coisa é o que... o, o, o, o fisioterapeuta, está cada um... eu estou sentindo que eles estão, sabe... co... correndo atrás. O psicólogo, eu estou vendo. Agora a gente [...]

Bianca: Então é por aí que eu digo que a Odontologia ainda é o começo, porque os médicos, tudo, vestem o modelo; quando é para parar, todo mundo pára. E a gente não. É desunida nesse sentido.

Célia: Você vê, quando têm esses concursos, aí têm médicos, enfermeiros, dentistas. Enfermeiro e médico... Enfermeiro, o pessoal vai, mas o pessoal vai, mas o pessoal não fica naquela ganância, naquela coisa. Médico sobra; falta médico. E dentistas, sabe o que é que os gestores dizem? Se não quiser, tem mil na fila. Já ouvi várias vezes, entendeu? Então, realmente a gente tem que ver que é a questão de, de a lei da, da oferta e da procura é essa, mas a gente tem que se unir enquanto classe... Como é que tem essa desvalorização do dentista? Se o salário da gente é bem menor do que o do médico.

A: A acomodação é associada e, logo, contraposta ao sexo: ter muitas mulheres na Odontologia. Qual a implicação de o analista ser homem e as participantes do estudo, mulheres? Seguem algumas frases ilustrativas:

Bianca: [...] Será que é por que é mais mulher?

Bianca: Eu acho que mulher é mais lutadora do que homem.

Célia: Não, não é isso, não!

A: Com a escuta analítica, reconhecimentos parecem mover-se e relações de mandato/submissão são problematizadas. Quanto as especificidades dos perfis das dentistas participantes do grupo marcam o discurso que se produz? No lugar de profissionais, vibram os posicionamentos: de queixa a uma busca de autoimplicação. O cansaço é associado à acomodação. O fator econômico é enfatizado. Dimensiona-se a força do lugar profissional com sua resistência, conforme as citações:

Célia: [...] Então, eu acho que falta isso: gente de pulso e tudo. Aí perguntam: "Célia, por que você num, num levanta essa bandeira?" Porque já tou cansada. 
Bianca: Não me submetia há um tempo atrás e não me submeto hoje. Se não tiver toca, eu não trabalho, não tem por onde. Ah... sem luva, não tem condição, não trabalho.

Célia: $\underline{O}$ plano de saúde pagar dez reais. Gente, isso é um absurdo, se submeter a isso.

A: A desvalorização profissional associa-se à imagem pública da Odontologia. Parece ensaiar-se um antagonismo, uma resistência, no lugar de dentista, na relação com o contexto. A reflexão é sobre o profissional e o trabalho/a área; a clientela, neste momento, não se desenha no discurso:

(E não acontece isso com as outras áreas profissionais?)

Célia: Não. A Odontologia, a propaganda tem atrás do ônibus. "Faça não sei o quê." Dá aparelho ortodôntico por cinquenta reais. Gente! Você vai no comércio, você vê essas clínicas populares.

A: A consciência (não seria inconsciência?) do dentista que é comprado é sinalizada. O profissional é posto como mercadoria, assujeitado à lógica mercadológica, conforme o recorte discursivo:

Dulce: Da consciência de cada dentista que é comprado.

A: O analista indaga a relação com a formação ao que Mônica refuta. A necessidade (dimensão de sobrevivência?) é ressaltada, como no trecho elucidativo:

(E o que é que tem de diferença na formação do dentista para existir esse tipo de...?)

Mônica: Eu acho que não chega nem a ser a cada formação. Eu acho que é a cada necessidade de cada um. Têm pessoas...

A: Investir em ser dentista e em consultório posiciona o profissional em um lugar mercadológico. As necessidades delineiam o "fechar os olhos" de profissionais com implicações para os colegas. "Devia vir a consciência" mostra a inconsciência de alguns. A profissional diferencia-se daqueles que se assujeitam. "Eu" e "a gente" constituem-se no deslizamento discursivo:

Bianca: É você investir em ser dentista [...]

Mônica: Para você começar a, a atender, você tem que montar uma estrutura e uma estrutura não é barato. Não é. Então dez por cento de quem se forma é que monta o seu consultório, porque pra, pra você investir em seu consultório é mais ou menos trinta mil para você colocar. E tem muita gente que não tem. Aí, o que acontece? Sai, está desempregado. Não tem. Não tem emprego pra nada... aí eu, eu concordo com, com, com Dulce; também devia vir a consciência, mas como tem muita gente que eu já... a gente já vê que assim, precisando não sei o quê, a família não tem posse, fecha os olhos e vai. Aí acaba com a gente.

A: Surge, na interlocução, o reconhecimento de uma relação de mercado que desvaloriza a profissão: 
Dulce: Aí é aquela história. Aí não é fechar os olhos e ir. É se prostituir, porque quando você escolhe a Odontologia, você sabia que era caro e que você ia enfrentar [...]

A: Lutar, unir e correr (atrás) são verbos que nos parecem com conotação de movimento e ruptura do individualismo. As dentistas estão mais implicadas? No dizer, há uma mobilização no que se refere a uma posição queixante, como nos exemplos:

Célia: Eu acho assim... é lutar mesmo. A classe se unir mais. A gente correr atrás [...]

Célia: Tem eleição de dois anos, de dois em dois anos. $\underline{\text { A gente também tem culpa, }}$ porque a gente se acomoda, entendeu? [...]

A: Sentidos produzem-se em relação ao lugar da dimensão econômica na Odontologia. A dentista, de modo reflexivo, coloca-se em posições diferentes em antagonismo:

Bianca: [...] A Odontologia é uma profissão que você tem que investir pesado e depois continua investindo. Então, não pode dizer nada. Não pode lembrar: "ah, eu vou entrar porque aqui tem uma faculdade." Não é por aí, não é? E tem esse mito: que é caro, tudo é caro, dentista é caro. Não é caro. É barato. Eu acho barato [...]

A: No deslizamento associativo, vai desenhando-se sutilmente um lugar para a clientela, não apenas para a profissão, na cena discursiva. A educação das pessoas é enfatizada. Não seria a ausência desta? Há comparação desfavorável com a prática médica. O analista é chamado de professor. O dentista parece surgir buscando manter o dente; o cliente procura resolver sua problemática, caso se refira ao dedo, alvo da atenção da Medicina. A dentista verbaliza como odontóloga e clientela numa encenação dialógica. A não valorização do trabalho do dentista surge no dizer por meio de uma posição profissional queixante que retorna:

Manuela: Eu acho que se a gente for avaliar o início da coisa, eu acho que ela começa com a nossa própria educação; a educação da pessoa, né? Ah. Eh. Vamos supor assim: quantas vezes a gente faz um check up geral e quantas vezes a gente faz um check up dos dentes, né? Quantas vezes a gente dá mais valor. Porque vamos pensar assim: professor, o dedo do senhor está machucado, no pé está com um problema muito grave [...] "E se o dedo estivesse machucado, você cortaria fora?" "Não, eu iria atrás pra resolver." E eu acho que a gente vem, da nossa profissão surgiu, o problema dela surge da própria educação geral, porque as pessoas não foram educadas pra valorizar a boca. Não foram educadas pra valorizar.

A: A clientela é delineada querendo extração em oposição às profissionais que desejam manter o dente. A qual clientela as profissionais se referem: de nível educacional mais baixo?

Mônica: Porque o que ela falou... Porque têm pessoas: "ah, tenho uma cariezinha. Eu quero extrair." E extrai. "Não, não pode extrair." Você tem que explicar a ele que aquele dente pode ser restaurado, aquele dente pode ser feito um canal e aquele dente pode ser mantido na boca. Não precisa ser extraído. 
A: Por Bianca, a Odontologia é vista no começo. Desprende-se uma mobilização da imagem da boca para a do paciente como um todo. Mais conhecimento é associado à juventude, como reconhecemos na interlocução:

([...] Passa por, por essa educação da população?)

Bianca: E daí a gente vê que a Odontologia está começando, porque hoje os jovens têm um conhecimento muitíssimo maior, né? E a Odontologia, a gente... porque pega o paciente não é só a boca, tem que ser como um todo.

A: Célia traduz uma bifurcação na discussão: fazer na Odontologia (prevenção, educação, que reconhece melhorando) e relacionamento com a profissão como programa. A relação com a clientela produz-se, no discurso, pouco a pouco:

Célia: Eu acho assim. Nosso momento aqui agora de discussão, eu acho que, que ele dividiu em duas partes: a primeira em questão, em relação o que é que a gente pode fazer na Odontologia. Então essa, essa questão preventiva, que eu acredito muito, porque eu acho que depois do PSF, o PSF tem dez anos, né? Fez dez anos agora. Eu acho que depois do PSF teve uma guinada muito grande justamente com essa parte educativa, porque a gente vai nas escolas, trabalha com eles [...] toda a parte de saúde bucal, toda a parte de, de, de prevenção, de, de, de doenças venéreas, trabalha muito também com eles; tudo, né? Gravidez na adolescência e outras coisas. Bom, eu acho que isso está melhorando muito. Eu acho que a prevenção, eu acho que é o tchã de tudo. Tanto é que eu estou vendo, o trabalho do serviço público, estou vendo a coisa está melhorando mesmo. E a outra questão que a gente também tá discutindo é em relação a gente enquanto, enquanto, enquanto programa, né?

A: Um sujeito político parece emergir ao lugar das profissionais em uma luta com as leis do mercado. Os sentidos produzidos neste posicionamento se movimentam. A palavra social parece libertar-se. As dentistas querem falar. $O$ contexto se pronuncia: relação com gestores, órgãos de classe, precárias condições de trabalho, como no recorte de algumas citações:

Célia: [...] Eu acho assim: enquanto profissional, tem muito a fazer, a gente. A gente tem muita responsabilidade a fazer em relação a, a, a, aos órgãos, a nossos órgãos de classe. Em relação a... a gente valorizar o que é da gente. Porque esse negócio desses convênios baratos, minha gente, pelo amor de Deus, isso se desvaloriza muito.

Célia: A gente é tão desvalorizada. A gente é tão desvalorizado como profissional que até os próprios gestores, eles não ligam pra a Odontologia [...]

Manuela: Voltamos pro mesmo ponto: política.

Célia: $R$, têm meses que eles não mandam glutaraldeído. Eu levei pro consultório [...]

A: O analista mostra sua percepção de um antagonismo entre uma preocupação com o paciente e uma Odontologia de boa qualidade versus a sobrevivência do dentista, o que se confirma no dizer do grupo:

([...] Eu estou percebendo que existe, na minha opinião, pelo que vocês estão colocando, um antagonismo entre uma preocupação com o paciente e em fazer uma Odontologia de boa qualidade e algo que tem a ver com a sobrevivência do dentista.) 
Grupo: Do dentista, é.

(Que está difícil. É impressão minha ou é isso?)

Grupo: $E$.

A: Conscientizar a população é a relação que se delineia por agentes institucionais em resistência ao contexto, às clínicas populares. A educação é vista com força na reflexão. Um contato dentista-população de informar surge a partir da seguinte pergunta do analista: "mas vocês disseram que tem algo que vocês podem fazer, né?", conforme os exemplos:

Dulce: Conscientizar a população.

Mônica: Eu re... recebi um paciente voltando. Ele disse: "ói, fiz o tratamento nessas, nessas clínicas populares." Ele sentiu a diferença quando foi pro meu consultório. Ele disse: "ói, têm seis dias que eu fui atendido lá. Aí por isso eu não voltei." E, e... estava falando. Ele sentiu a diferença. Ele não... "Tinha isso, não era fino. Isso". A população sabe, agora a gente tem que informar, tem que ver...

A: $O$ analista faz confrontamento investigativo quanto às dentistas assumirem uma função pedagógica, de informar à população, ao que elas respondem tangencialmente:

(E vocês fazem isso?)

Bianca: O que a gente pode fazer é isso.

Grupo: É isso.

A: No imaginário, o dentista emerge como "arranca-dente". Tece-se, com Célia, uma visibilidade da implicação do lugar do profissional. Parece que se delineiam dois perfis de odontólogos: um que valoriza e o outro que desqualifica a profissão. Ela faz referência ao segundo perfil do qual se diferencia. A clientela que busca extração também marca características de pacientes com quem Célia se relaciona no posto. Bianca ratifica o dizer, comentando a lógica da produtividade/quantidade, conforme as frases:

Célia: Eu tou substituindo. Eu estou há pouco tempo lá na Céu e aí ontem já aconteceu, mas eu achei engraçado ontem: eu tou na porta e aí vem uma, uma paciente: "doutora, a senhora é dentista?" Eu disse: "sou." "A senhora é... a senhora faz um encaminhamento pra mim?" Eu disse: "por quê?" "Não, porque eu tou com um dente aqui pa arrancar, né?" Não fala nem extrair. Arrancar. "E aí eu preciso fazer fora, porque aqui não dá ponto". "Aqui não dá ponto, por quê?" "Não, porque você... você é de que área?" E ela era, ela seria da minha área. "Porque outro dentista que tava aqui, eu vinha arrancar e aí, como eu tenho dificuldade, não sei o quê, ela falou lá... e aí disse que sangra muito, não sei o quê; ele disse que não podia fazer, porque tinha que dar ponto e lá, e lá no posto não dá ponto." Eu disse: "e é? Não, mas pode vim que aqui dá ponto e eu dou ponto." Então, a gente mesmo, tá? Desvaloriza a nossa profissão: ou por preguiça ou por num... entendeu? Não ter habilidade. Mas não é isso que deve falar. Não dar ponto? Uma coisa boba, entendeu? 
Célia: Têm uns que diz que é, é, estar em posto de saúde é cômodo. Tem que atender de qualquer jeito [...]

Bianca: [...] Mas não, tem que ter produtividade. Já trabalhei com colega que ele fazia sete e botava setenta.

A: $O$ analista mostra que percebeu diferenças conforme os locais de atendimento e as investiga mais. Ele busca que as dentistas aprofundem mais sobre o atendimento da clientela, pois, no início do encontro, elas falavam muito genericamente da profissão. Nesse momento, emerge um comentário sobre a heterogeneidade do grupo e a riqueza do trabalho em realização:

([...] uma diferença pelo que eu percebi entre o serviço público e o privado, interior e capital.)

Célia: Existe.

(Quais são as diferenças?)

Célia: [...] Você pegou um grupo bom, viu? Eu estava até pensando em casa, porque aqui tem, tem de todas as idades, época, né? De formação e que fazem várias coisas, por exemplo: tem gente que faz consultório, que é só... né? E legal, viu, esse grupo? Então... vai ter um... um trabalho rico.

A: Alguns exemplos discursivos serão citados, sinalizando um deslizamento para a reflexão do lugar da clientela pelas dentistas com a indagação supramencionada do analista sobre as diferenças conforme o local/contexto. São enfatizadas singularidades entre os posicionamentos das odontólogas: não muda com o ambiente; modifica conforme o setting; a valorização do dente pela clientela é diferente no interior e na capital, ou na periferia desta; condições e relações de trabalho são distintas, quando externas ao contexto do consultório. Competição entre odontólogos e representações da extração de dente são enfatizadas. É evidente um antagonismo de dentistas em relação à posição da clientela:

Bianca: O que eu acho... O que eu acho é que na realidade é que não muda nada.

Célia: Muda, Bianca.

Manuela: A forma que o homem do interior vê o dentinho e a forma que o homem da capital vê o dentinho. Sim. É a forma que o homem do interior valoriza no interior o dentinho e o da capital...

Bianca: [...] Vivencio no consultório particular. Eu continuo no Wa fazendo parte, mas assim: eu, eu já peguei no interior paciente. No interior, não. Periferia de capital. Paciente vem pra mim para extrair, arrancar o dente. Eu não arranco [...]

Bianca: [...] Se eu passo uma hora com meu paciente no consultório, eu passo uma hora com meu paciente no Wa. Claro que muda o quê? É... Muda o quê? O sugador.

Bianca: O sugador é velho, as atendentes não me pagam toda hora, mas eu digo: "ói, o sugador!" Ah, não tem; não é tudo brilhando. "Ói, mas limpa aqui" [...] 
Maria: Aí existe também competição.

Mônica: [...] A diferença é essa, dos pacientes. Até um moço falou: "tinha um pra extrair, outro não tinha." "Vou extrair?" "Não." "É para extrair os dois?" "Não". "Vou extrair só o que tenho que extrair; não vou extrair o outro." Aí ele saiu e tá. "Eu vou ali e pago para, para extrair." "Tudo bem. Pode ir no, no outro consultório e extrair. E pagar para extrair. Agora eu não extraio."

Carla: Às vezes, eu falo pro paciente: "olha, sua pressão está alta." Ele faz: "eu sempre extraí e nunca tive nenhum, tive nenhum problema. Então vá, vá" [...]

A: Célia relativiza a posição do paciente do interior. O passado é associado à resistência intensa da clientela que queria que o dentista arrancasse dente. "A gente" é o termo genérico referente à profissional. Os dentistas surgem começando a mudar a cabeça da clientela em uma posição educativa?

Célia associa a clientela do setor privado a uma maior exigência. Outras dentistas configuram que a clientela do interior respeita mais os dentistas, bem como é mais carinhosa e receptiva. Esta é vista escutando, agradecendo e cumprindo seu papel. Os pacientes da capital emergem oferecendo maior resistência, posicionando-se em um lugar de saber, inclusive maior do que o das profissionais:

Célia: Mas hoje em dia... Ói, eu, eu, eu já trabalhei muito no interior. Eu estou entendendo tudo o que vocês estão falando. Antigamente tinha muita resistência do paciente do interior. Eles eram meio que... Só queriam arran... arrancar, arrancar, arrancar. Mas eu acho que a gente mesmo já começou a mudar um pouquinho a cabecinha deles, entendeu? Porque tá todo mundo... Nesse sentido, eu estou vendo, estou vendo que está evoluindo [...]

Célia: Eu acho que a clientela, que a clientela privada é mais exigente.

Manuela: Eu acho que o pessoal do interior respeita a gente muito mais.

Mônica: É mais carinhoso.

Manuela: É mais... mais receptivo.

Dulce: O que você faz ali, ele escuta, agradece e cumpre. Aqui [capital] tem mais resistência. Já sabem tudo. Sabem do todo mais do que a gente.

A: Surge uma horizontalização entre os lugares da relação dentista-paciente pela clientela da capital que é vista como uma desvalorização profissional, por exemplo, por meio do pronome de tratamento "você" dirigido à odontóloga. Parece que a correlação de forças é fundamental no contato:

Manuela: Às vezes, nem chamam nem a gente assim, né? "E aí como é que você está, está tudo bem?" Assim... trata como se você fosse da patotinha dele.

A: Os pacientes do consultório são reconhecidos, em relação ao serviço público, com maior exigência e "cri-cri", havendo a dificuldade de cobrar por quem é profissional. Com convênio, a clientela é vista "se achando", porque paga, o que 
posiciona a odontóloga como serviçal. A relação de serviço, crivada pelo econômico, parece ser um nó na interação dentista-paciente:

Célia: [...] eu acho o pessoal de consultório mais exigente, mais exigente, mais cri-crie eu não sei cobrar. Eu digo: "ói, sabe de uma coisa? Vou ficar no serviço público" [...]

Bianca: [...] No Wa, o pessoal vai lá se achando, se achando... porque tem... porque paga o Wa. Então você é serviçal dele. Não é... Não é... serviçal... a questão.

A: A Odontologia Preventiva é relacionada a um menor custo e uma maior facilidade no fazer. A dentista lamenta a possível extinção da especialidade com tal prática. A ampliação da relação dentista-cliente para a dimensão da prevenção seria modificar a Odontologia configurada como curativa ao que parece haver uma ambivalência na posição profissional:

Manuela: [...] A Odontologia Preventiva é mais barata, é mais fácil de ser feita em todas as especialidades. É uma pena que a especialidade vai se extinguir, né? Se a gente fizer a preventiva, não vai chegar ao canal, né?

A: Dulce acha que a base é a prevenção. Célia delineia uma evolução da clientela pobre por conta desta. Há um dizer constituído na Saúde Pública? Surge um escape da prevenção, mas por quem? Prevenção/primeira consulta produz-se no discurso politizado. Demonstraremos o comentado com algumas citações:

Dulce: $\underline{A}$ base é a prevenção, porque eu trabalho em cima disso [...]

Célia: $R$, assim: e quando eu comecei minha profissão pra hoje, eu vejo que houve uma evolução muito grande em relação ... aos pacientes, né, pobres? Em relação... Por conta da prevenção. É importantíssimo. Tanto é que hoje nós tivemos uma reunião lá na Secretaria e aí o Ministério da Saúde tá puxando a orelha da gente, porque a gente não está atingindo os indicadores de prevenção. Se não melhorar, vão cortar o PSF. Todo mundo ficou lá: "ó..." De olho aberto. Porque na hora de fazer prevenção, neguinho vai embora, entendeu?

Célia: [...] E a prevenção é o que eles mais exigem, a prevenção e a primeira consulta, por quê? Porque em cima da primeira consulta, você pega o paciente sem cavidade. $E$ a prevenção é o foco de tudo, né? [...]

A: Ao serem as dentistas questionadas, facilidades na Odontologia também são mostradas na interlocução. Há diversos exemplos do mencionado, como no tocante ao status profissional:

Manuela: A gente tem uma facilidade. Se a gente for financiar um carro é só mostrar a carteirinha do CRO [...]

Dulce: Cartão de crédito pra gente é enorme.

Mônica: [...] Esqueci a carteira de motorista. Aí não tinha a carteira de identidade. Também não tava comigo. Tava na minha outra bolsa. Troquei a bolsa, não sei o quê. Aí eu tava com a carteirinha do CRO. Ele olhou e fez: "a senhora é dentista, é?" Aí eu disse: "sou." Aí ele olhou e fez: "vá, vá, tá" [...] 
A: O analista faz investigação confrontativa em relação à desvalorização da Odontologia, já que as profissionais falaram de seu status:

(Então, como é isso, porque... Como é isso, então, uma profissão que é desvalorizada...?)

A: Alguns dos exemplos que surgem elucidam o analista sendo posicionado como professor pelas dentistas e a Educação na cenografia discursiva, justificando a (des)valorização profissional:

Manuela: É educação, professor. Educação.

Manuela: E voltamos pra velha educação da criança que cresce, sabe? Se você não se comportar, você vai pro dentista.

A: Uma das dificuldades reconhecidas por Luara é atender o paciente. A clientela é vista chegando com medo, achando que vai sentir dor. Mas não existem situações dolorosas no atendimento odontológico?

Luara: Uma das dificuldades da gente é atender um paciente que já chega lá sem nem conhecer a gente, sem nem saber o que a gente vai fazer, já chega com medo. Por isso, porque eles acham que vai sentir dor, que a gente vai fazer ele sentir dor.

A: Ao serem diretamente provocadas pelo analista sobre elas também sentirem medo em sua prática, as profissionais refutam. Foi diferente do segundo encontro em que as odontólogas se posicionaram verbalizando sobre suas vulnerabilidades. Parece que elas buscam aproximar-se, neste encontro, de uma posição mais fortalecida:

(Já chega com medo; só que esse medo é o medo só do paciente ou o dentista também tem medo na sua prática? Como é?)

Grupo: Medo?

Não [...]

A: Maria configura o lugar do dentista de ter que disfarçar, mostrar confiança e domínio. Invisibilidade da situação dirigida à clientela e aparência de segurança ao dentista marcam as práticas odontológicas? De profissionais inexperientes? $\mathrm{O}$ saber, neste momento, é associado por Célia a ela, profissional, diante do paciente que quer determinar o fazer da odontóloga:

Maria: É, de vez em quando, você tem que disfarçar. Não pode mostrar que você não está confiando naquilo que você faz. Tem que ser confiante naquilo que você faz, que você domina [...]

Célia: [...] "doutora, só quero aquele remédio, aquele remédio pa passar a dor." Eu digo: "não, você vai sentar ali. Quem vai entender o remédio que você vai tomar e se vai precisar sou eu." 
A: A relação que se desenha é de uma clientela, cuja posição antagoniza com o lugar de quem é dentista. Parece que a questão de quem domina na relação odontólogo-paciente é fundamental:

Mônica: $R$, uma coisa que, que acontece muito: dentista na maioria marca por hora, assim marca horário marcado. Uma grande maioria dos médicos é... por ordem de chegada. Se a gente atrasar, acontecer uma urgência, um imprevisto, o procedimento demorou, o paciente está lá fora xingando você, já está reclamando.

A: No decorrer da interlocução, o analista dirige a reflexão das dentistas para o lugar da clientela, pois, no início do encontro, elas tendiam a falar genericamente da profissão. Ele pergunta se a clientela obstaculiza sempre. Flexibiliza-se, no dizer, que nem sempre. É posto que, na relação com ela, o dentista tem que se impor. Há deslizamento da posição pronominal em que a dentista se coloca no discurso:

([...] Como é que vocês veem esse, esse lugar da clientela? Como é que vocês pensam sobre a clientela? A clientela dificulta sempre ou não? Como é?)

Grupo: Sempre não.

(Sempre não? E como é?)

Célia: $\underline{A}$ gente tem que se impor. Na verdade, a gente tem que se impor. Se chegar um paciente falando alguma coisa, você, a gente, eu já começo a me impor. Chegou uma paciente essa semana que quebrou o pau lá fora, não sei o que, brigou com o taxista. Chegou na minha sala, queria quebrar comigo. Eu falei bem baixinho com ela. Baixinho mesmo [...]

A: Com o tom do antagonismo nas relações na Odontologia, o analista indaga a respeito do lugar do acompanhante para que as dentistas pensem mais sobre este terceiro integrante da tríade odontólogo-paciente-acompanhante. No manejo transferencial, o trabalho analítico ocorre em uma zona intermediária entre as demandas das dentistas de falarem sobre si e suas práticas e as do pesquisador que configura seu estudo como uma intervenção nas relações entre profissionais e suas atividades, seus pacientes e acompanhantes, produzidas em discurso:

([...] o acompanhante também, quando tem acompanhante? Como é?)

A: O acompanhante é associado, sobretudo, à criança; a imagem da mãe destaca-se. Surge a mãe posicionando-se em um movimento de fusão com a clientela: senta na cadeira, por exemplo. Também ela é reconhecida amedrontando mais a clientela do que dentistas, conforme algumas citações que demonstraremos abaixo:

Grupo: Acompanhante é mais com criança.

É a mãe só.

[...] senta na cadeira. 
[...] as mães amedrontam mais as crianças do que a gente.

A: O analista questiona se às vezes o acompanhante é um facilitador: (Às vezes ajuda também?)

A: Com a marcação do lugar de assento, o acompanhante também é reconhecido facilitando a relação dentista-paciente, mas se mantém, sobretudo, como quem a dificulta, conforme os exemplos ilustrativos que recortamos entre aqueles que emergem no grupo. O atendimento odontológico é visto como penalidade ou relacionado à recompensa ofertada pelos pais. O "fantasma do medo" perpassa o contato com odontólogos:

Grupo: $\underline{\text { Ajuda. }}$

Só se pegar uma mãe que cooperar.

Mas há algumas que cooperam. Poucas, mas têm.

Ele tem medo e passa o medo pra criança.

Ele fica... Às vezes, a criança está lá quietinha, deixando a gente fazer o tratamento e o pai tá: "olhe, não vai doer, não! Olhe, tenha calma, viu? Depois a gente vai tomar sorvete. Não faça isso, não."

Tanto a criança faz alguma coisa e diz: "se fizer isso, vou levar para o dentista." Não, já é... Coloca a gente como penalidade da criança.

E da recompensa: "se você deixar, ganha isso" [...]

A: Surge o reconhecimento de uma mudança na educação infantil, no respeito da criança em relação ao adulto, com implicações na interação dentista-paciente pediátrico quanto ao posicionamento profissional de limites:

Manuela: Agora a, a educação, ela vem presente em muitos pontos, não é, $R$ ? Hoje em dia pra você encontrar uma criança que respeite um adulto é muito difícil. Antigamente a gente respeitava muito mais os adultos. Então, até essa, até essa educação mesmo de você não ter respeito pelas outras pessoas atrapalha a gente. Porque a gente não consegue se impor. Se o pai não consegue se impor, imagina, a gente vai se impor! Às vezes, é difícil.

A: O analista mostra que a economia está presente na organização do discurso:

([...] muitos termos como cobrar, orçamento, é, ou mesmo a questão do valor, valorização, alguns termos muito até da Economia, utilizados na Economia, na ciência econômica. Vocês acham que isso acontece por quê? Essa questão do, do, do...do financeiro, do econômico aparecer tanto no discurso... de vocês?)

A: Entre os exemplos, as dimensões de sobrevivência e recompensa pessoal surgem em resposta à indagação do analista. Em detrimento do fazer, cobrar é visto como não aprendido. Um lugar para a formação profissional de não dar conta das 
questões da Odontologia? A economia na relação entre agentes institucionais e clientela é uma questão nevrálgica:

Célia: Porque a gente tem que sobreviver, não é, R? Ter dinheiro, tem um salário... até pra a gente se sentir recompensado [...]

Luara: A gente aprende a fazer, não aprende a cobrar.

A: Seguindo o raciocínio desenvolvido, o analista indaga a respeito do antagonismo entre ser dentista e sobreviver:

([...] Como é essa relação entre ser dentista e também sobreviver? Como é que fica is...?)

A: Emergem vários posicionamentos entre as dentistas. Em oposição ao profissional precisar sobreviver, surge promover saúde à clientela custe o que custar. A quem? Às odontólogas? Elas necessitam pagar (e caro)? A separação do escritório do consultório também mostra as dificuldades do lugar do profissional no plano econômico. O paciente não quer efetuar o pagamento:

Manuela: [...] Essa questão assim: eu preciso promover saúde naquele paciente custe o que custar, mas infelizmente a gente precisa promover saúde do paciente, mas a gente precisa comer, a gente precisa... pagar [...]

Manuela: Eu particularmente, eu tive uma professora nessa área. Ela queria... Ela não tem só o consultório, ela tem um escritório. Então o paciente senta, faz o orçamento no consultório e vai teoricamente no escritório conversar sobre o financeiro; depois que trabalha... entendeu? [...]

Manuela: Que eu passo os valores, que ele tem consciência de tudo que ele está fazendo. Por exemplo, eu tinha, eu tinha um grande problema com um paciente que na primeira mensalidade, na primeira manutenção do... Quando ele montava 0 aparelho, ele achava que não tinha que pagar, porque ele já gastou com a documentação, então ele achava que não tinha que pagar. Infelizmente eu tive que instituir no meu consultório, quando liga pro paciente pra marcar: "olha, lembra que na primeira consulta já incide a primeira mensalidade." A partir desse dia, eu já não tive mais problema.

Mônica: $O$ que acontece muito, já que Manuela falou, é a questão da consulta. $\underline{O}$ paciente no consultório não quer pagar consulta.

A: A clientela posiciona-se na relação com o dentista como se estivesse em uma loja. Na mobilização discursiva, o lugar do paciente é desenhado em um contato comercial, distinto da vinculação às imagens de tratamento e educação outrora delineadas:

Carla: Como se fosse numa loja. Ele chega em uma loja, faz o orçamento e tal. "Aqui está cara". Vai em outra loja. "Ah, aqui, não está cara". Assim...

A: Outros exemplos na interlocução mostram que a dimensão econômica da relação dentista-clientela é notória. Facilidades são acenadas. Uma posição de autoanálise das dentistas é marcada. Surgem termos como negócio, valorização e 
investir. A formação continuada é reconhecida sob a perspectiva da valorização. Parece que há uma procura de fortalecimento do lugar de odontólogas no mercado, sendo a autoimagem profissional constituída nesse contexto. Implicações do trabalho, na luta pela sobrevivência, para a qualidade de vida também são acenadas. Acompanhemos algumas citações:

Mônica: Ói, $R$, a gente estava comentando um negócio, quando tava saindo do, do outro encontro no elevador: "a gente reclama, reclama, reclama, concordamos, certo, mas a gente..." Aí, você... Pronto, você diz: "as facilidades?" Uma das facilidades... Manuela pensou que assim irmãos que tem na área de exatas e que não têm o mesmo padrão de vida dela que ela tinha hoje.

Mônica: [...] Eu trabalho, eu, eu sou formada há quatro anos, e minha mãe não me dá um real nesses quatro anos. Eu que me mantenho. Eu fiz minha especialização, eu que me mantive. Eu comprei meu material, eu que me mantive. Então... O negócio é que a gente fica meio complexado. Poxa, a gente está investindo tanto, e os outros não vê... a valorização, como é, a valorização, o reconhecimento pelos outros. Como é que a gente quer investir mais, se a gente não, não tem o retorno?

Manuela: Porque na verdade o que se valoriza são os próprios cursos, né?

Mônica: [...] a gente não ganha mui... mal, entendeu? Mas não à altura do, do nosso esforço, do, do nosso investimento.

Manuela: E, às vezes, pra gente ter um padrão de vida assim, bonzinho, eu particularmente só tenho horário de almoço algumas terças; os outros dias, eu não tenho horário de almoço. Os outros dias, a gente tem horário para entrar no consultório, mas não tem horário para sair.

A: A visibilidade da situação contornada é marcada por um novo ângulo. Célia amplia o estresse para a vida do profissional de saúde de um modo geral. O deslizamento do verbo ser para estar, referente ao "estressante", parece uma mobilização interessante, uma desnaturalização produzida na instituição discursiva:

Célia: [...] Eu acho que essa qualidade de vida em geral do profissional de saúde é extremamente, está extremamente estressante [...]

\section{Terceira cena: o fechamento do encontro}

A: Entre outros aspectos, o analista finaliza o encontro lembrando o próximo dia e posicionando-se com "a gente", forma discursiva que percebeu, no decorrer das reuniões, que o aproximava das dentistas:

(Pessoal, a gente já tá na hora [...] Aí a gente se encontra semana que vem na quintafeira no mesmo horário, está bem? Boa semana pra vocês.) 


\subsection{O quarto dia de grupo}

Nesse encontro, reconhecemos três cenas fundamentais. A primeira é uma proposta-oferta do analista. A segunda é a rotina das dentistas na Odontologia e a terceira é a finalização do encontro.

O lugar do pesquisador/analista é bem focado na facilitação da discussão sobre as relações dentistas-pacientes-acompanhantes como proposta. Anteriormente, ele as analisou nos dizeres das odontólogas sobre suas práticas. O analista faz investigações/intervenções, com base na análise prévia dos encontros passados e de algumas indagações disparadoras. A solicitação geral é que as dentistas falem da rotina; algumas dimensões discursivas que emergem terminam tendo uma reflexão mais aprofundada.

O lugar das dentistas e de suas práticas, entre outros aspectos, constitui-se nas relações com a clientela com particularidades em diferentes settings, quando as profissionais se referem às suas rotinas. São reconhecidas singularidades entre as dentistas. Atender parece, muitas vezes, identificado a tratar. $\mathrm{O}$ objeto institucional da Odontologia constitui-se como tratamento odontológico?

As dentistas posicionam-se em vários lugares discursivos, como "eu", "a gente", "nós", "você", sujeito oculto e indiferenciando-se da clientela. As odontólogas parecem mais analíticas. O dispositivo institucional cadeira (De quem? De dentista?) desenha-se. A vulnerabilidade profissional é acenada. Tentar é um verbo que se destaca na relação dentista-clientela. A formação na Odontologia é pensada. O contato professor-aluno na contemporaneidade é visto sem preparar o profissional para a prática/o fazer. $\mathrm{O}$ estudo emerge como defesa às dentistas; ter que se resguardar é delineado. O início profissional é associado a particularidades. Quem manda nos parece central. Dimensões econômicas marcam o lugar do odontólogo. A temporalidade contorna sentidos, inclusive quando engendrada por parâmetros de produtividade.

$\mathrm{Na}$ dinâmica da transferência, há um assinalamento por uma dentista do "escape" das odontólogas às indagações do analista nas reuniões. Efeitos de reconhecimento produzidos com o manejo deste encontro em que o analista solicita de início que as dentistas falem dos pacientes e acompanhantes, de sua rotina? Ao analista/pesquisador, é endereçado "como concluir" com tantos questionamentos 
formulados pelas participantes. Produz-se na relação das odontólogas (como clientela) com o analista/pesquisador (como profissional) dar (mais) tempo a este. Parece surgir uma solicitação de um caminho, uma direção a seguir.

O lugar do paciente é desenhado com particularidades. A clientela é reconhecida chegando nervosa, com medo. São vistas por nós diferenças nos posicionamentos dos clientes pelas dentistas de acordo com a experiência profissional. Em algumas profissionais recém-formadas, a primeira imagem que vem, ao falarem de sua rotina, é a do paciente chegando e da anamnese, não do exame clínico. Sinais de movimentos na formação na Odontologia? Nas sessões de retorno da clientela, há transformações nessa imagem.

Nos contatos com o paciente, o diálogo é reconhecido. Há um lugar especial para a criança que se constitui, mas não sem ambiguidades. $O$ paciente especial também tem uma localidade inscrita no discurso. Há referência a um período de adaptação com a clientela infantil, mas este surge como não fazer na Odontologia? As cenas que constituem a Odontologia são as dos procedimentos odontológicos?

Quanto à posição da clientela, ressaltemos ainda que esta se delineia como de força de resistência, antagonismo, com nuanças: às vezes, é "ótima". Surgem peculiaridades na clientela a depender dos serviços e da urgência. Vulnerabilidade também é associada ao lugar do paciente. A clientela emerge evoluindo no conhecimento, mas não sem ambiguidades. Efeitos da Educação/informação? Tais efeitos não são associados à formação na Odontologia e ao fazer dos dentistas? Se o saber produzido nos cursos de Odontologia se constitui como técnico e com falhas na construção das práticas, o que dizer a respeito do saber sobre as relações? De onde este pode ser produzido, se não na formação e com a experiência?

O lugar do acompanhante é marcado com menor ênfase. Por que as dentistas atendem pouco crianças? O acompanhante é pensado comumente fora das cenas odontológicas? Muitas vezes, a posição deste parece de um outro intrusivo, que atrapalha, sobretudo quando o atendimento é de criança. A imagem da mãe destaca-se. As oposições entre mãe e filha surgem com implicações à relação dentista-paciente.

Há desdobramentos nas posições discursivas e dos sentidos atribuídos a elas no decorrer desse encontro. 


\section{Primeira cena: uma proposta-oferta do analista}

A: Em círculo, com a presença de seis dentistas, o analista posiciona uma proposta-oferta de mais reflexão sobre o paciente e o acompanhante nesse dia, já que percebeu que as dentistas tendiam a falar mais de si e de suas práticas nos encontros. Em tal manejo, ele solicita estrategicamente que as profissionais verbalizem sobre sua rotina, conforme recorte discursivo abaixo:

([...] Vocês disseram que queriam pensar mais sobre a Odontologia, sobre o ser dentista, pra depois pensar sobre a relação, né? Queriam ver o que é que acontecia com o papel do dentista pra pensar sobre a relação com o paciente e 0 acompanhante. Então hoje eu tenho uma proposta que é justamente de poder pensar um pouco mais sobre essa relação com o paciente e o acompanhante. O que é que acontece? Aí eu queria que vocês me falassem de um dia de atendimento de vocês. Como é um dia de atendimento? Como é a rotina, né? [...])

\section{Segunda cena: a rotina das dentistas na Odontologia}

A: A segunda cena refere-se à verbalização das dentistas de sua rotina. Salientemos que Luara, Denise, Manuela, Mônica e Bianca trabalham no setor privado, enquanto Mônica e Bianca também atuam no serviço público. Célia trabalha neste contexto apenas. Todas as participantes desse encontro expressam que trabalham na capital, sendo que Denise, Mônica e Manuela também atuam no interior. O atendimento de crianças é relatado, mas não como exclusividade, entre as profissionais.

As dentistas falam das áreas que exercem. Luara verbaliza que faz uma subárea da Ortodontia com criança e também atende em Dentística. Bianca comenta que atende em Endodontia e Clínica; Mônica também. Célia posiciona-se atendendo em Clínica. Denise localiza-se fazendo Endodontia e Clínica. Manuela refere-se a fazer mais Ortodontia do que Clínica.

Sobre a descrição da rotina das dentistas, Denise é quem primeiro a apresenta. Em seu dizer, surgem muitos intervalos/reticências. A profissional está a pensar? No desenho que configura a relação na Odontologia, surge, na entrada, a imagem do paciente ao que sucede um lugar profissional de diálogo, fazer anamnese, indagar 
acerca da queixa e outros aspectos, para, então, proceder ao exame da cavidade oral. A relação precede a técnica odontológica:

Denise: $O$ paciente entra. Pra mim, é assim: o paciente entra e ... faço aquela anamnese toda, né? Pergunto a queixa principal. Faço outras perguntas. Aí depois vou pra parte do exame, é, intraoral.

A: O lugar do acompanhante que se delineia parece externo à relação com o paciente. O primeiro é posicionado como influência potencialmente nociva ao segundo, sobretudo à clientela na infância, o que pode desenhar-se na tensão, no nervosismo, gerado a esta. Ocorre o deslizamento do vocábulo acompanhante (termo genérico) para mãe (representante específico daquele). Na exemplicação de um caso de uma paciente especial, a oposição da relação mãe-filha transforma-se em um antagonismo entre dentista e paciente. "Vamos abrir a boquinha" é uma assertiva da dentista que mostra um movimento de fusão/indiferenciação entre profissional e paciente, já que quem abre a boca é a paciente. Acompanhemos o mencionado no exemplo:

Denise: $O$ paciente vai e o, o acompanhante fica... sentado assim do lado na, no escritoriozinho. E... eu acho que às vezes assim, não todos, mas às vezes o, o acompanhante influencia muito, principalmente criança assim. Eu percebo que têm crianças que ficam ah, ficam mais tensas, mais nervosas, quando a mãe tá presente. Eu tenho uma paciente especial que, que tudo que a mãe pede... Eu converso com ela pra ela fazer tal coisa, por exemplo, esta semana, ela teve lá, eu estou fazendo o período de adaptação, aí eu peço a ela: "vamos abrir a boquinha?" Tudo com calma. Se a mãe repetir o que eu falar, ela faz ao contrário [...]

A: Produz-se um lugar para a mãe de pressionar a dentista a fazer com velocidade o procedimento. A posição atribuída à acompanhante é de não querer diálogo na relação dentista-criança, mas extração. Fazer de qualquer jeito e "logo" são endereçados da acompanhante à profissional, pois aquela quer ir embora. $\mathrm{A}$ qual contexto específico a dentista se refere? Uma mãe em posição de empecilho e a paciente já nervosa na chegada se destacam.

Observemos o recorte discursivo:

Denise: [...] Fica assim pressionando a gente a... pelo menos eu, a fazer rápido o procedimento. Não gosta que a gente fique assim conversando com a criança. Têm mães que não gostam, eu percebo. Quer que extraia logo de qualquer jeito e pra ir embora. Tem mãe, tem uma mãe de uma paciente que fica assim: "ave, eu odeio dentista. Não quero nem ver". Fica lá, lá sentada, só falando coisas negativas. Isso, eu acho que influencia bastante. $\underline{A}$ menina já chega nervosa. [...]

A: Há referência a uma anamnese completa, ao preenchimento de prontuário, à assinatura do documento, para, então, ocorrer o exame clínico. Percebemos um espaço para a interação antes do procedimento odontológico. Com a clientela 
infantil, há a imagem do "período de adaptação", primeiras consultas, em que o consultório é apresentado. Por que esse período surge como "não fazer nada"? Por não ser construído com os procedimentos odontológicos?

No deslizamento associativo, de um lugar à criança, emergem referências ao paciente especial; este é associado ao medo e a um contato dentista-cliente com calma. Também há relato de conversa com o paciente adulto. O diálogo produz-se, como no início, ao término do atendimento odontológico. São salientadas a higienização da sala e a troca de pacientes. Seguem os exemplos:

Denise: [...] toda aquela parte de anamnese completa, que tem aquele prontuário pra gente preencher, né? Aí, se for adulto, vai assinar. Se for a criança, o responsável assina. Aí faz a parte de exame clínico, tal e aí faz... Eu nunca é... Sendo crianca, primeira, primeira consulta, eu nunca faço nada. É só período de adaptação, independente da criança. Segunda, terceira consulta, também não faço nada. $\vec{E}$ um período de... mostrar a ela as coisas, como é o consultório. Porque eu tenho muito paciente assim, especial, que tem medo [...] Então, tem que ir com muita calma assim de... Depende da criança. Se for adulto já... como é lá no interior, eu conheço muita gente, eu converso sobre a família, tudo, né? Aquela...

Denise: Aí, pronto, o paciente termina, aí eu converso um pouco, sai. Aí a parte da limpeza da sala [...] troco os pacientes. A rotina é essa.

A: Os primeiros dias são identificados com o período de adaptação da criança de modo que a clientela se posiciona sem medo. Esse momento surge, no exemplo que segue, como importante. Mostrar-fazer antes de ir diretamente? A orientação que sabemos que os dentistas recebem em Odontopediatria é: falar-mostrar-fazer. Livros infantis são vistos mediando a relação entre dentista e criança. Ao final da sessão, produz-se motivação/recompensa da clientela com "uma caixinha" com objetos associados à Odontologia ou brinquedos ofertados à criança.

Demonstraremos o mencionado com as citações abaixo:

Denise: [...] Tem paciente lá, um ano e sete meses, que ele já chega, ele já quer sentar logo na cadeira, porque os primeiros atendimentos é o período de adaptação e agora ele já vai sozinho, já senta, já sabe o que é que vai ser realizado. Não tem medo de nada. Por isso que eu acho importante essas primeiras consultas mostrar o ambiente. A gente aprendeu muito na faculdade sobre isso, né? O... o mostrar-fazer antes de, de ir diretamente ao tratamento.

Denise: Eu tenho assim, é, livros infantis que eu compro em congresso. Têm uns livrinhos lá bem educativos na sala de recep... na recepção. Quando a criança entra, eu mostro. Eu também tenho... É... Toda criança, ao final do tratamento, tem a, a parte de motivação. Tem uma caixinha. Eu elaborei uma caixinha. Aí toda semana, eu compro coisas diferentes. Assim relacionado à Odontologia. Mas agora assim: como eu nunca mais eu fui pra congresso, eu estou comprando mais assim: brinquedos [...]

A: Bianca é a segunda dentista a apresentar sua rotina. Surge dar uma olhada na ficha clínica, instrumento de trabalho, antes de o paciente entrar, tanto no 
consultório, quanto no outro local onde trabalha. O sentido da visão destaca-se antes do fazer. A atendente é posicionada no lugar de recepcionar, preencher a ficha (no diminutivo?) e entregá-la à odontóloga. A clientela é localizada na "cadeira de dentista" (dispositivo institucional da Odontologia, tal como o divã o é na Psicanálise?):

Bianca: [...] Minha rotina é, é assim. Eu sempre atendo paciente com ficha clínica. Então, quando eu chego no consultório, eu... quero as minhas, as fichas clínicas estejam separadas e também no Wa. Eles têm fichas. Então antes do paciente entrar, eu já dou uma olhada no que é que eu vou fazer [...] E no consultório a minha aten... a minha atendente já recebeu [...] preencher a fichinha e coloca, né? Entrega antes deles entrarem. Eu vou lá, dou uma olhadinha. E quando eles entram é na minha ca... na cadeira de dentista [...]

A: O acompanhante está fora das cenas odontológicas? Sua presença pode ser problemática? A tentativa que se produz no contato é de manter uma relação de confiança entre dentista e paciente, conforme os trechos discursivos:

Bianca: E quando tem criança é... eu tenho dois mochos, porque eu também faço cirurgia, então eu às vezes tenho um mocho pra auxiliar. Eu tiro. Meu mocho fica lá no cantinho. Eu ofereço, tal. Mas é difícil entrar acompanhante. E o engraçado que é mais marido e mulher do que filho (Risadas).

Bianca: [...] Eu sempre fico só com o paciente. Aí eles vão pra minha cadeira. Eu já vi mais ou menos a ficha ou então eu vou perguntar qual a queixa dele. E tento manter uma relação de confiança com eles.

A: Com a clientela de primeira vez, com medo, a dentista antecipa seu fazer por meio da fala. A autoridade surge na perspectiva da definição de papéis no contato: a dentista é quem resolve.

O relacionamento dentista-paciente é concebido como de confiança. $O$ pronome "você" no discurso indireto nos deixa na dúvida a respeito de quem fica vulnerável na relação dentista-paciente. O cliente? Não poder agir é enfatizado. Um lugar para a afetividade no contato torna-se nítido; a rotina é um bom relacionamento com o paciente.

Vemos o comentado nas citações que seguem:

Bianca: Entendeu? Quando eu sinto que é um paciente, que é a primeira vez, que está com medo, aí tudo que eu vou fazer, eu antecipo. Eu digo a ele. Digo tudo. Se não a gente vai conversando. Vai... Eu, eu, eu gosto de, de criar um elo de confiança. Por isso que em uma outra vez, a gente teve uma sessão, eu disse que tinha autoridade. (Hum) Uma questão de autoridade. Essa autoridade é no sentido assim: ele saber que só quem resolve sou eu. E eu só resolvo o que ele me disser. Então, ele tem que me dizer o que quer, o que não quer, se está gostando, se quer parar, se está doendo [...]

Bianca: [...] Então, eu posso assim: meus tratamentos, meu relacionamento com 0 paciente é de confiança, porque eu acho que a Odontologia é uma coisa assim que mexe com a gente de uma maneira muito íntima, né? Pra você fica... sujeito ao outro. Sem poder agir. Então você tem que tá... Você tem que confiar [...] Eu tenho pacientes 
assim: mais adultos e idosos. E tem um lá assim: me abraça e Deus abençoe e não sei o quê. E deixam fazer todo o tratamento [...] Claro que existem exceções, mas não é o rotineiro.

A: Em continuidade ao que Bianca fala da rotina, o analista retoma uma dimensão emergente em encontro passado de o corpo não ser sentido no atendimento odontológico:

(É, você disse, Bianca, que esquece do tempo [...] A impressão que me deu é que vocês não sentem o corpo de vocês durante o atendimento. Só vão sentir depois.)

A: O analista acompanha posicionamentos das odontólogas ao que ele verbalizou, entre os quais, recortamos alguns deles elucidativos. Concentração, esquecimento de sensações, pensar no tratamento/fazer (estratégia cognitiva focal) são marcados. As dentistas localizam-se como "a gente", "você", "eu" e sujeito oculto nos desdobramentos discursivos. Surge o reconhecimento da área de saúde com muita pressão, estressante, em função do envolvimento.

Este é um momento de flutuação do pensamento em grupo, não de relato individual da rotina de trabalho; movimento associativo promovido pela intervenção analítica. Incorporar uma outra pessoa no trabalho chama-nos atenção como efeito de (des)subjetivação produzido na prática. O termo "incorporar" nos parece sugerir as imagens de dentro/interno/entrar/in e corpo na constituição do contato dentistapaciente. O pensamento é reconhecido com foco no fazer:

Luara: [...] Exige muita concentração. E a gente está muito, fica muito concentrado durante $o$ atendimento.

Denise: Aí esquece as outras sensações.

Luara: Acho que você tem que pensar no que você está... Só no que você... no tratamento, naquilo que você está fazendo. Não que eu fique tensa, mas você está pensando só...

Célia: Eu acho que toda profissão da área de saúde é muita pressão e é muito estressante. Você se envolve. Você se envolve também. Eu acho que, eu acho que $\underline{a}$ área de saúde como um todo.

Manuela: Eu trabalho com meu irmão. E ele me diz que eu sou uma pessoa em casa e sou uma pessoa trabalhando. Completamente diferentes. (É?) Ele diz que quando eu entro pra trabalhar parece que eu incorporo uma outra pessoa completamente diferente do que eu sou em casa. Meu esposo também reclama muito. "O dia trabalhando, não fala nada?" A gente está ali pensando no que está fazendo, né? Ou caminha ou masca chicletes, né? Não vou fazer as duas coisas ao mesmo tempo, né?

A: Implicações à saúde surgem e atenção à corporeidade constitui-se como medida compensatória e de vigilância no tocante ao lugar do profissional, conforme as citações abaixo: 
Denise: $O$ ortopedista falou que a gente assim, que força muito essa região, 0 antebraço, tem que fazer alongamento; eu não faço, entendeu? Isso que a gente tem que cuidar da nossa saúde. Alongamento, fazer uma, um exerciciozinho físico. Que a gente fica o dia todo naquela posição. Só caminha...

Bianca: [...] Problema de audição, eu não tenho. De visão, eu não tive lá, né? [...]

Luara: Às vezes, eu tenho que vigiar assim o tempo todo pra ver a postura.

A: Há a marcação de um lugar para o profissional recém-formado: desespero e submissão a qualquer forma de trabalho. Ele não escolhe? Não é sujeito de seu desejo?

Termos econômicos crivam o dizer referente à Odontologia, como cara e investir. Parece haver uma naturalização da situação que é desenhada anteriormente às práticas, que se constituem cotidianamente na Odontologia: "sempre foi e é e vai ser sempre!" Surgem a produtividade e os objetivos de um outro, em um relacionamento patrão-empregado, a comprometer a saúde de quem é profissional da Odontologia. A dentista em locução, por estar em vigilância, "ainda" não sofre efeitos da insalubridade das condições de trabalho. Ela verbaliza com os pronomes "você" (em um discurso indireto sobre o dentista) e "eu", quando apresenta a singularidade de sua vivência.

No segundo exemplo, a dentista fala na primeira pessoa do singular. A temporalidade "em aberto" de seu atendimento, reconhecida como dificuldade sua, é relacionada ao envolvimento pessoal da profissional com seu fazer. Um fazer com o qual se funde/envolve? Concentração no trabalho que produz não ver o tempo passar?

Acompanhemos os recortes discursivos abaixo:

Bianca: [...] Porque tem muita gente que é recém-formada desesperada, não é? E pega qualquer coisa. Aí não cumpre, não cumpre o Código de Ética. Mas nessa questão do, de recém-formado de, de pelo menos tem que vir antes de escolher a profissão, porque a Odontologia não mudou. É cara, é difícil, sempre foi e é e vai ser sempre! Você tem que investir. Então, quando você faz o vestibular, você tem que saber disso, e não ficar desesperado. Se ficar desesperado, essa prostituição vai acontecer. Se ficar desesperado, vai se submeter a qualquer tipo de trabalho. Vai ter que cumprir é produtividade, né? Metas do... não nossas, mas do patrão, do... né? $\vec{E}$ aquela... do chefe. Sei lá. Aí você vai se prejudicar tanto na saúde física, mental, profissional, em todos os aspectos. Então eu, eu, eu procurei sempre assim, não sei, desde cedo, né? A, a vigiar esses pontos negativos e não cair neles. Então, talvez por isso que eu não, num, eu ainda não tenha reflexo disso, apesar do, né, do tempinho de profissão, porque sempre fiz o consultório particular, sempre trabalhei em serviço público.

Bianca: [...] Talvez essa questão de tempo, eu sempre boto em aberto, porque é um ponto difícil pra mim. Por eu me envolver com tudo que eu faço. Tudo. 
A: $O$ analista endereça o dizer de Bianca às outras profissionais para que as dentistas se posicionem acerca do que fora enunciado sobre o tempo no atendimento odontológico:

([...] Bianca está dizendo que tem algo dela nisso, mas vocês acham que essa questão do tempo é, aparece também em vocês? Ah, você está dizendo que sim, Luara. Como é?)

A: Luara acena que a temporalidade marca seu lugar e delineia o tempo estimado para o cliente estressando-o em situação de espera, bem como atrapalhando-a.

O início profissional é relacionado por Denise à tensão da dentista de querer cumprir o tempo. O presente é associado a não se estressar. Fazer seu trabalho sem querer olhar o relógio mostra que uma "solução" para seu estresse é a invisibilidade do tempo. Configura-se o efeito de mobilização do lugar de Denise com os encontros grupais.

Acompanhemos os trechos ilustrativos que seguem:

Luara: Eu acho que pra mim é uma das coisas que mais me atrapalha. Porque assim... tem aquele tempo esti... tem o tempo estimado, o tempo marcado, né? A hora marcada para o paciente. Aí o paciente tá lá fora. Isso é uma das coisas que mais estressa o paciente. De ficar esperando, que o pessoal reclama [...]

Denise: [...] Eu no início, eu no início eu sofria assim, ficava tensa também. As duas primeiras semanas que eu comecei no interior, marcava paciente, eu ficava tensa, porque queria cumprir, mas hoje eu não vou mentir, não me estresso mais, não. Faço o meu trabalho; não quero nem olhar. Tem um relógio ali do, do lado assim, do meu lado, eu nem olho. Nem... Já disse à minha secretária: "nem me fale que tá atrasado, que não tá." Porque eu tava vendo que eu tava me desgastando, tava me estressando. Já... Lembra que eu falei a primeira vez que eu vim aqui: que eu tava tão estressada, tão assim chateada com, com tanta coisa que eu disse, eu parei pra pensar e disse: "não vou me estressar." E assim: tou, tou... bem melhor [...]

A: No recorte da interlocução abaixo, o analista indaga Bianca como e o que vê de mudança na relação com a clientela com o passar do tempo. Ela posiciona-se com hesitação e sem saber se está a responder o que supõe ser a expectativa do interlocutor. No passado e presente, são associados diferentes atributos ao lugar do profissional. A temporalidade marca os movimentos discursivos. Os cursos de aperfeiçoamento e especialização são vistos como um mercado paralelo para dar conta das lacunas da graduação, por exemplo, quanto ao fazer:

(Como é que você vê essa mudança, é, na questão da relação com a clientela, né? O que é que você vê que mudou na relacão com a clientela de antes pra agora?)

Bianca: Eu não sei se eu sou uma pessoa assim, né? Fala certa para isso. Mas a relação... eu acho que antigamente, apesar de nós não termos... Não sei se é isso a per... a resposta que você quer. Mas a, ao... Apesar de nós não termos conhecimento 
científico que hoje se tem, entendeu? Nós tínhamos maior capacidade. Nós sabíamos como resolver os problemas. Tínhamos que resolver. Hoje é... eu vejo muitos colegas mais novos, com muita ciência, com muita, muito é... conhecimento, mas que no momento de agir, eles não sabem o que fazer. Muito inseguros.

(E de onde vem isso?)

Bianca: Eu acredito que também da falta de prática. É porque aí é... eu não sei se eu posso responder. Mas assim: na faculdade, não tá tendo a prática que se tinha ou também os professores não tão estimulando a prática dos alunos, porque existe também uma coisa paralela que tá surgindo muito em todo, que tá, tá desenvolvendo nin todo, acho, mundo, Brasil, tal que são os cursos de aperfeiçoamento e os cursos de especialização. Está sendo dada uma, uma valorização muito grande e é... como o mundo, o mundo gira em, em, em torno do dinheiro, é um bom meio.

Bianca: É, como um mercado paralelo. Eu digo isso, porque hoje eles têm muita literatura, muito conhecimento, muito trabalho científico, muita pesquisa e na hora $H$ não sabem o que colocar, como é que coloca aquilo em prática. Então, pra eles saberem como colocar aquilo que eles sabem em prática, eles têm que ir pra um aperfeiçoamento. Porque se não eles passam um ano estudando a boca do paciente, a impressão que dá é essa, lá no, no slide, no livro e um minuto pra pegar, ver a boca do paciente [...]

A: $O$ analista assume uma postura investigativa quanto ao ensino atual e passado:

(Então, o que foi que mudou no tipo de instituição de ensino de antes pro tipo de instituição hoje?)

A: Nos exemplos elucidativos que apresentaremos, surge o que (não) se faz hoje na faculdade. O fazer, no tempo presente, é associado a interesse pessoal, não à obrigatoriedade, em oposição ao passado em que o aluno tinha que praticar tudo, e o professor localizava-se com uma outra postura. Diferenças nas relações de ensino na Odontologia, mas não só nessa área, são delineadas, conforme o tempo. A imagem que se enuncia é do contato professor-aluno, o que põe em discussão a formação profissional:

Bianca: [...] Você veja, eu tenho uma coleguinha que ela fez assim: essa questão de extração. Era dupla. Nós tínhamos dupla, mas eu tinha que fazer, e a outra tinha que fazer [...]

Manuela: [...] os professores de antigamente eram muito mais exigentes.

Mônica: Eu já me formei tem quatro anos. Os alunos de quatro anos atrás, cinco anos, seis anos atrás, eram bem mais interessados do que os alunos de agora.

Célia: A gente tira, veja bem. Eu vivo isso no ensino, no ensino... de faculdade, ensino médio ou colégio médio. Meus filhos estudam hoje, eu acho que nem a metade do que eu estudei na minha época [...]

Denise: Eu acho que, eu acho que os alunos não estão saindo preparados, não. Eu acho, eu acho que os alunos não estão saindo preparados de jeito nenhum.

Manuela: Eles eram treinados pra resolver tudo. Nós não fomos treinados pra resolver tudo. Nós fomos treinados pra conhecer superficialmente tudo. 
Denise: Eu acho que teve muito... Na faculdade, teve muito: se eu gosto de prótese, aí faz mais prótese. Isso acontece porque eu fiz só uma prótese na faculdade e ninguém nunca me obrigou. Fazia canal de molar ni minha turma só eu e outra pessoa [...]

Mônica: Antigamente os profissionais mais antigos faziam tudo.

Bianca: [...] Hoje as pessoas fazem é, é vestibular pela... já dizendo que vai ser especialista nisso, naquilo. Como, se você nem viu? Nem viu! Não sabe nem o que é aquilo. Antes não, você tinha que cursar, fazer tudo.

A: Após a digressão analítica, o analista busca retomar o foco: falar da rotina. O tempo continua a produzir deslizamentos discursivos. O estresse é visto associado ao fazer. Mônica fala de não ter ficha clínica no serviço público onde trabalha:

( $E$ as outras pessoas, o que é que pensam? Eu queria que voltasse assim: a rotina que eu perguntei, né, algumas pessoas terminaram sem colocar.)

Mônica: Voltando a questão do tempo dela. Eu sou muito assim: perfeccionista. Então eu cronometro tudo. Aí fico meio, como até Denise veio me falar, meio estressante quando eu faço [...] Eu tento, eu tento manter aquele meu horário certinho. Sobre a conversa de atrasar, aconteceu, mas ninguém pode prever algum atraso [...] No atendimento do, no consultório e no serviço público, duram pouco, por quê? No serviço... Não na minha relação com o paciente, porque é assim: você diz que tem ficha clínica lá no Wa, eu não tenho ficha clínica [no serviço público].

A: Mônica comenta ter um mapa de atendimento resumido no serviço público. O trabalho passa a ser mais marcado pela relação com o contexto do que com a clientela? Acompanhemos o mencionado no trecho que segue da interlocução em grupo:

Mônica: [...] Boto no mapa de atendimento.

Mônica: Você coloca o nome da pessoa, a idade.

Denise: E o que fez, né?

Mônica: E o que fez.

A: Aos poucos, surgem, como exceções, os pacientes que irritam a dentista. A dimensão de poder nos parece central no mencionado. A profissional busca evitar mostrar o que sente, sua irritação/chateação, por exemplo, conforme as citações elucidativas:

Mônica: [...] Têm pacientes assim que não podem... É muito cheio de frescura. (Hum) Entendeu? Como é? Pensam que sabem tudo.

Mônica: Quer obrigar você a fazer alguma coisa que você sabe que aquilo não pode ser feito.

Mônica: E acaba irritando você aquela situação. E eu tenho muita dificuldade nisso: em evitar transparecer que eu me irritei ou que eu me chateei com aquela situação.

Mônica: Mas em questão a... No mais, no, no... Sem ser as exceções. No geral, não. Tenho uma boa relação com os pacientes. 
Mônica: Eu tenho pacientes que assim: que são ótimos, que vêm de seis em seis meses certinho [...]

A: No serviço público mencionado, é posto que não há uma sequência de tratamento. A lógica é da urgência, e quem manda não é a profissional. "Você" e "eu" surgem relacionados ao lugar da profissional:

(Sei. E... E você falou que sua rotina no serviço público seria com esse mapa...)

Mônica: Só.

(de atendimento?)

Mônica: Em relação a pacientes, não. Relação mais ao tra... ao tratamento. Você não tem uma sequência de tratamento pra saber o que é que eu fiz, o que é que eu vou fazer na próxima sessão, o que é que eu vou fazer na outra, ao contrário do consultório.

Denise: Aí você faz o que... Por exemplo, abre a boca e vê o que tá mais urgente, né? Manuela: Ou o que ele manda, né?

A: A rotina de Célia é marcada pelo acolhimento e mapeamento. Em seu lugar de profissional, há reconhecimento de estresse. Os pacientes lutam por vaga e formam fila; deixam de aparecer como sujeitos/pronomes da oração. A dentista cobra-se em relação ao tempo e à produtividade. Denise contrapõe que ela está disponível ao contato, à conversa, com o paciente:

Célia: [...] Mais ou menos como a das meninas. Só que assim: lá é... A gente começa a atender de manhã. Tem geralmente... Eles chegam cedo demais, né? Já chegam, até o posto fechado, porque ficam muito... assim... Me estressa, porque eu acho que eles não mereciam, tá, chegar lá no posto cinco e meia da manhã, seis horas, né? Hoje em dia ainda é assim. Pra conseguir vaga, né? E aí eu chego, faz o acolhimento. Sou eu e outra colega. Ela geralmente faz o acolhimento. Vai lá na, na recepção, conversa com todos, ou seja paciente pra gente ou paciente pra médico. Geralmente ela faz o acolhimento, porque isso está preconizado no, no, no programa, né, no PSF. [...] lá também faz o mapeamento [...]

Célia: $E$ aí a gente vai, formam a fila, não é? Geralmente eu sou assim. São doze que a gente atende, né? Pela Secretaria. São doze atendimentos mais três urgências [...] Eu tenho muita dificuldade é no ponto de atendimento. Muita. Porque eu fico até muito estressada, inclusive já chego dizendo à atendente que eu nunca consegui, $R$, atender mais do que doze pessoas. Atendo, mas eu termino muito tarde. Eu não nego pra ninguém atendimento, mas eu atendo muito tarde. Têm colegas meus... Ah, vários! Acho que a... Eu acho que a única lerda sou eu, porque o resto atende dezoito, vinte, não sei quê.

Denise: Não, mas eu acho que não é que você seja lerda, é porque tem aquela... $\underline{o}$ contato com o paciente de conversar.

A: O corredor (com pacientes) mostra uma outra relação dentista-clientela no serviço público referido. O verbo na primeira pessoa do plural em "vamos ficar sentadinhos" parece evidenciar um movimento de aproximação/identificação/ 
indiferenciação da dentista com a clientela no dizer. Por outro lado, reconhecer os próprios limites surge à dentista? A imagem desenhada do fazer configura características peculiares à relação dentista-atendente na construção da prática:

Célia: [...] Enquanto eu converso com meus pacientes, eu digo: "gente." Aí fica aquele corredor. Aí eu agendo tudo. Depois eles ficam tudo sério. Aí no corredor, não tem cadeira no corredor, tem lá na recepção. Eu digo: "gente, vamos ficar lá sentadinhos. Eu sei que o posto está cheio, mas daqui a pouco vai desocupando. Vamos ficar sentadinhos, porque vai demorar. De tal número em diante, eu só vou atender depois das dez." Eu já sei o meu limite. Eu sei que a metade eu atendo até dez, a outra metade até onze e meia. Mais ou menos, tá? Então começo assim, quando deu oito horas. Minha atendente já chega tarde. Eu chego primeiro. Eu arrumo a sala. Eu ... faço o agendamento de todo mundo. Quando eu termino, ela tá chegando. Então, eu não vou chegar depois das oito pra... esperar ela. Então eu chego, faço tudo. Ela chega... Às vezes, eu já tou até com o primeiro paciente na cadeira.

A: A dentista mostra-se, com singularidade, em uma posição empática na relação com os pacientes no contexto do serviço público:

Célia: [...] Eu digo assim... eu comento... "olhe, eu faço assim, minha gente, o que eu queria que fizessem em mim. Porque se eu fosse ser atendida por um dentista, eu queria que fizesse o mesmo que eu tou fazendo em vocês. Por que é que eu vou fazer diferente em vocês, se eu vou querer uma coisa melhor em mim? Não posso!"

A: Há a configuração do antagonismo do paciente, o que é associado, de forma hesitante, à irritação da dentista. A profissional posiciona-se não se submetendo à clientela. Ocorre uma identificação da mão, instrumento corporal de seu trabalho, ao lugar da odontóloga:

Célia: [...] teve uma senhora semana passada que conseguiu me irritar. Ela queria me irritar, mas não me irritou. Teve um dia... A gente começando a ficar calejada, já, já começa a saber lidar. Aí eu sei que ela não arrumou pra ser comigo nem com o médico da equipe. Eu digo: "ói, a senhora vai agora pro médico." Ela é, é diabética. Descompensada, queria fazer uma extração. "Não tem condição." Aí fui conversar com o médico. Aí ele deu as instruções de tudo de como ela fazer, retornar ao posto. Pronto. Ela virou um raio. Eu digo: "eu não faço, minha amiga. Eu não faço. Não vou meter a mão onde eu não posso me meter, onde eu não devo me meter."

A: O antagonismo na relação dentista-cliente é ressaltado. No posto, há o reconhecimento de um lugar para a interação em equipe. O estresse profissional parece surgir relacionado a convencer o paciente do posicionamento profissional para evitar, por exemplo, uma situação letal. O verbo tentar surge associado à posição da odontóloga. Há uma referência a uma clientela pobre, distinta daquela de consultório:

Célia: [...] A gente começa a ler e ver lá. Ou conversar com colega, com médico da equipe. Ah, esse paciente é trabalhoso. Então isso... Essa, essa interação da gente no posto é muito boa. Dos médicos, dos enfermeiros e tudo. Então eu não tenho problema, mas às vezes aparece um... paciente ou outro. Eu digo: "ói, se o senhor morrer ou tiver alguma coisa, aí vai ser complicado pra mim." "Não, doutora, que nada! 
Isso não vai acontecer." Eu digo: "não, meu amigo, quando o senhor morrer, a família vem toda em cima de mim. Ói de mim. Eu vou perder minha profissão. Não." Aí no fim ele disse: "não, a senhora tem razão. Tá certo. Tá certo..." Entendeu? Mas a gente às vezes se estressa pra tentar... Mas assim. Não sei se é porque eu atendo uma populacãa pobre, que eles são... são mais humildes, claro, né? Do que o pessoal de consultório [...]

A: Luara aproxima sua rotina à das colegas. No consultório particular, a cena inicia-se com a chegada do paciente. Anamnese, diálogo e preenchimento de ficha são enfatizados. Há espaço para a interação. No retorno da clientela, a ficha clínica norteia o fazer da odontóloga antes de a clientela entrar. A profissional reconhece que escuta a demanda, a prioridade, de seu paciente:

Luara: Não, assim... É mais ou menos parecido. No consultório... particular, o paciente chega. A gente, pelo menos assim, as mais novas, a gente aprendeu bem a fazer a anamnese, né? Teve sempre que ter prioridade. A gente conversa, preenche toda a ficha. Aí tá com a... atendendo o paciente. Quando eles vêm nos retornos [...] sua ficha está lá. Aí antes dele entrar também, eu vejo o que é que eu vou fazer. Quando ele entra, eu já sei o que vou fazer. Quando tiver várias coisas, eu converso com ele. Pergunto se ele tem alguma prioridade, entendeu? [...]

A: No contexto do convênio, a ficha é substituída por um sistema no computador, uma anamnese (no diminutivo) com o odontograma, ao que a dentista introduz questionamento seu em caso de procedimento mais invasivo para se resguardar:

Luara: Agora assim, no, no... Em relação ao convênio, a gente não tem a ficha, mas como tem o sistema no computador, vem uma anamnesezinha, mas uma coisa assim bem básica. Vem o odontograma e assim: diz se o paciente é alérgico. Mas mesmo assim, quando eu vou fazer o procedimento, se eu for usar anestésico, fazer alguma extração, procedimento mais invasivo, eu sempre pergunto. Porque que a gente não tem essa ficha. Aí tem que perguntar [...]

Luara: É, resumido. Aí no caso, se eu for fazer extração. O paciente vai me relatar que tá compensado e se eu fizer a extração e tiver algum problema, não tenho como me resguardar.

A: Denise relata sua inovação no registro sobre a clientela de convênio, como forma de se proteger, sugerindo a mesma a Luara:

Denise: É, porque assim, eu atendo por convênio. Aí tem aquela perícia inicial. Um convênio e o outro, é tudo pela internet. Só que eu faço a fichazinha e eu elaborei uma anamnese, resumida, mas uma anamnese que o paciente assina já pra eu me resguardar disso [...]

A: Manuela ressalta que sua rotina é bem distinta daquela das colegas por ter pouca anestesia, fazer mais aparelho, não precisando se resguardar tanto; ela também especifica que, com o que faz, há uma maior quantidade de pacientes: 
Manuela: Minha rotina é bem, bem, bem diferente da delas, porque... eu uso... uso pouco anestesia, né? Eu faço mais aparelho. Então, a gente lida com um volume maior de pacientes, né? A gente não tem essa questão de ter que ter esse resguardo todo com relação a... diabetes, hipertensão, essas coisas todas, né?

Manuela: É. Eu faço mais de Orto do que Clínica. Só um paciente que "só faço clínica com você", eu faço. Mas eu não faço muita clínica.

A: $O$ analista indaga se as dentistas acham que as transformações na atualidade tiveram impacto na relação com os pacientes. Surgem, conforme os exemplos elucidativos abaixo, comentários diversos da posição atribuída às odontólogas que ressaltam, por exemplo, uma clientela mais exigente, informada, que quer se aproveitar de quem é dentista ou um contato na Odontologia crivado pelo jurídico. Quanto aos cuidados orais, há uma multiplicidade de sentidos no dizer. A clientela que evoluiu, do ponto de vista odontológico, foi por causa da Educação? As profissionais colocam-se como "você" e "eu" (em sua singularidade):

Mônica: [...] o paciente ultimamente é, é mais exigente [...]

Mônica: Ele já vem sabendo o que é. O que é o tratamento odontológico. Antigamente, não. Você é, você era praticamente leigo. Hoje em dia não existe [...] Todo mundo sabe um pouco. Sabe qual é a mensagem na televisão. Sabe. Sabe de tudo. Então ele já vem com um certo conhecimento.

Luara: Mesmo, mesmo o paciente às vezes sendo leigo, ele quer se aproveitar de você. Já aconteceu isso comigo: do paciente...

Denise: Eu acho assim... que, que... Pode ser que o paciente teja mais esperto em relação a isso, mas ainda acho assim: a parte de, de escovação, de higiene assim, adequada, ainda é muito deficiente.

Mônica: Quando você pega as pessoas mais novas, você vê que... não têm tanta cárie. A escovação já é melhor. Dificilmente você pega uma pessoa de vinte anos que, que, que perdeu um dente. Então assim, têm pessoas mais carentes que perdem [...]

Célia: Já foi bem pior. Com certeza.

Manuela: Hoje em dia tudo gira em torno do processo.

A: $\mathrm{Na}$ interlocução, surge que o dentista hoje faz nada ou muito pouco por causa do medo. Tal profissional é visto como humano, passível de erro, ao que o estudo emerge como contraponto e o reconhecimento do não estudar da geração atual se produz como uma preocupação, conforme as citações que seguem:

Bianca: Faz nada. Muito pouco. Mexo em nada e tenho medo de, de tudo, né?

Célia: A gente é humano. Pode haver algum erro, né? Agora a gente tem que estudar. Inclusive eu tou preocupada com essa geração que não está estudando. 
A: O analista posiciona-se finalizando o encontro grupal, referindo-se, em forma de síntese, ao configurado no dia. Ele lembra o próximo encontro às dentistas:

(A gente... a gente já tá... na hora de finalizar, né? [...])

([...] vocês colocaram toda essa questão da formação, é, da diferença do tempo da Odontologia mais generalista pra a Odontologia atual em que se busca a especialidade [...] algumas particularidades: a questão do tempo. É... Algumas pessoas ressaltaram que conversam muito com 0 paciente [...] também particularidades em relação aos serviços, não é? Então, a gente vai continuar na próxima quinta no mesmo horário. Tá bem, gente?)

A: É marcado que continua a análise das dentistas, quando termina o encontro. Há pelas odontólogas um reconhecimento dos diferentes lugares demandantes na transferência: das dentistas e do pesquisador, produzindo uma interlocução em que, às vezes, o que o analista instiga (sobre a relação) as dentistas não respondem (tendem a verbalizar mais de si na Odontologia do que dos pacientes e acompanhantes). As participantes falam delas, pois se veem relacionando com um psicólogo? Um psicoterapeuta? Célia, provavelmente identificada com o lugar de quem faz pesquisa, posiciona o analista/pesquisador, podendo limitá-las, estabelecer um corte ao que Denise ratifica, de acordo com os exemplos:

Célia: $A$ gente saiu no elevador assim rindo, achando engraçado. Aí... Acho que foi Bianca ou foi aquela menina que faltou hoje. Ela disse: "Célia, você hoje... falou foi muito!" "Minha gente, me desculpa, mas na próxima eu vou ficar calada". Aí fiquei matutando em casa. Eu disse: "meu Deus, será que a gente está atingindo o objetivo de R? [...]"

Denise: Porque às vezes ele pergunta uma coisa e a gente começa a desabafar outras coisas [...]

Célia: Isso, a falar, falar, falar. Porque assim: você é um psicólogo, né? A gente está se ajudando, uma terapia [...]

Célia: A gente quer lhe ajudar, né? E se o grupo tiver... pode, pode ir cortando.

Denise: Pode ir cortando.

A: Concluir é endereçado ao analista como problemática. Responder às múltiplas perguntas das dentistas é o que se configura para ele no discurso. Célia oferece mais tempo ao analista ao que Denise confirma. Bianca marca o lugar queixante das dentistas. "E aí o que direi?" parece uma indagação destinada ao analista, na suposição de saber, na solicitação de uma direção a seguir. Quanto o antagonismo da relação dentistas-analista pode produzir do contato entre odontólogas e pacientes é a questão que o analista se faz, no pensamento, norteando intervenções do próximo encontro:

Acompanhemos algumas das falas que emergem na interlocução: 
Bianca: Você tá conseguindo concluir alguma coisa de tantos...

Bianca: De tantos questionamentos e, e sem uma solução? Que a gente tá levantando questionamento, questionamento [...]

Célia: Se você precisar da gente. Assim que se formou, vai ter que voltar [...]

Denise: Se precisar se estender, né?

Bianca: E outra coisa: "o que é que ela quer finalmente? Hoje reclama disso, amanhã daquilo. Já reclamou, já reclamou." "E aí o que direi?"

A: $\mathrm{O}$ analista não responde às perguntas formuladas pelas dentistas, ofereceIhes liberdade e, por outro lado, reafirma a importância da presença delas nos encontros seguintes; sem as participantes, não haveria a pesquisa. A escuta das demandas das odontólogas garante a realização deste estudo (demanda do pesquisador) que surge no hibridismo das ofertas, pedidos e recusas: a diferença de posições sendo reconhecida no relacionamento entre o analista institucional do discurso e as dentistas, ou no contato da Análise Institucional do Discurso com a Odontologia, com as diversas implicações dos lugares de quem faz um estudo acadêmico e das dentistas dele participantes! Assim, como na relação entre odontólogas e pacientes, as oposições se fazem presentes na transferência:

(Então, aqui é um, um grupo de escuta sobre as práticas odontológicas de vocês, tá? E esse grupo é pra vocês se movimentarem mesmo, com liberdade. [...] E por isso que a gente tem esse caminho dos... seis encontros. E é muito importante... aí eu queria reafirmar, né, com vocês a presença de vocês?)

A: Surge, não sem ambivalências, que o encontro deste dia, com proposição focada no paciente, foi ótimo. Também reaparece no equilibrismo das demandas, a oferta de uma dentista de mais tempo ao analista:

Célia: Aí hoje foi ótimo, que você focou num assunto, numa coisa, né? Que eu acho. É assim. As outras... as outras duas. Se bem que eu acho que também foi bom. Foi muito importante que a gente foi... Falou da profissão como um todo, como profissional, colega, né, a instituição. Mas hoje você já propôs de outra forma: a gente com o paciente. Foi legal. Eu adorei... tou gostando.

Denise: $R$, vamo, vamo estender mais um pouquinho?

(Despedidas.)

\section{5. $O$ quinto dia de grupo}


Reconhecemos, no quinto encontro, quatro cenas fundamentais. A primeira é: mais profissionais, menos pacientes e acompanhantes no discurso? A segunda é o analista no lugar de dentista. A terceira delineia-se como as dentistas nos lugares de pacientes, acompanhantes e psicólogo. A quarta configura-se pela finalização do encontro.

O lugar do pesquisador/analista, que constantemente se inclui no grupo, é, sobretudo, de mostrar mobilizações nos encontros, retomando várias nuanças de outros dias. Ocorrem repetições em seu dizer por se produzir na interlocução um "mal-entendido" ou nonsense: as dentistas confirmam como um todo a indagação inicial do analista, mas, ao argumentarem, mostram que tal ratificação é parcial: da constatação de as profissionais falarem mais de si nas reuniões, mas não da interpretação analítica do porquê de tal dinâmica. Não foram ouvidos os indicadores da polifonia do discurso pelo analista como possíveis sinalizadores ricos em sentido das diferentes posições/demandas entre as dentistas e o pesquisador. $O$ analista faz intervenções no decorrer do encontro e manejos transferenciais, produzindo efeitos de descentração em lugares discursivos. Há associação do trabalho analítico pelas odontólogas a aprendizado e novos sentidos.

No lugar das dentistas e de suas práticas, as profissionais querem falar, a continuidade dos encontros. As problemáticas são delineadas como múltiplas e, por outro lado, emblematicamente identificadas, em síntese, à profissão. Elas se desenham no que é reconhecido fora de domínio. As condições e relações de trabalho (gestor, auxiliar, interação dentista-dentista, mercado, entre outros aspectos) sobre 0 que falam parecem produzir, nas odontólogas, sofrimento/sentimento de desvalorização. Por outro lado, as odontólogas reconhecem que gostam do trabalho. Dimensões concernentes à formação e às implicações quanto à saúde de profissionais; reconhecimentos sobre lidar com limites e distinção entre mostrar e experienciar surgem. "Minha cadeira", ampliação dela ao lugar do dentista, mostra, no dispositivo político da Odontologia, a assunção de força de quem é agente institucional.

Indiferenciação (“Quando a gente saiu da cadeira.”), generalização por meio da qual é atribuída característica do dente à pessoa (“Comecei a doer.") emergem em lapso. Há diferentes posições entre as dentistas e mobilizações do lugar discursivo em uma mesma odontóloga. A experiência constrói sentidos particulares. Questionar é reconhecido como ocorrência ao término do atendimento. 
Inicialmente, as odontólogas queixam-se e querem defender seu lugar de "outro". $\mathrm{Na}$ instituição Odontologia, parece que não se constitui a relação profissional-paciente-acompanhante como figura, mas sim as formas/condições (que, às vezes, falham) de produção do saber técnico. Fazer (contornar, controlar e terminar), em nossa compreensão, constitui-se como meta da Odontologia. $(R e) p e n s a r$ sobre a formação de dentistas não seria importante?

Com o tempo, as odontólogas vão implicando-se mais (não é linear o movimento de saírem da queixa), abordando ângulos da relação profissionalpaciente-acompanhante. Elas falam da vulnerabilidade, do não controle no contato, do medo e do não saber. Bianca posiciona-se ao lado da profissão, o que se mobiliza no sexto encontro.

O lugar do paciente é reconhecido no atendimento odontológico em uma relação de domínio, prazer e envolvimento de dentistas. Domínio inclusive corporal? "É até prazeroso" mostra a ambivalência do gostar. Alguns pacientes são vistos como empecilhos. O cliente pode surgir infantilizado, mesmo sendo um adulto. "[...] em frente a uma extração" desenha o contato com o dente.

Como se constrói o relacionamento dentista-paciente? Dimensões espaciais caracterizam esta relação que se delineia, algumas vezes, como uma luta. Uma inversão de lugares discursivos é esporadicamente percebida. Relativizações ocorrem no dizer. Ver a individualidade, a diferença, a dor e o sofrimento que se produzem na prática ao paciente mostra outros contornos na visibilidade e configuração de forças com a clientela. Há um lugar para o reconhecimento da fragilidade de quem é atendido.

O lugar do acompanhante é reconhecido como, às vezes, problemático, mais do que o do paciente. Há quem relativize. Uma relação de poder configura-se entre dentista e acompanhante, como se este buscasse ocupar todos os espaços e defender os pacientes da prática odontológica. Há uma busca para localizar os acompanhantes fora das cenas odontológicas? Com o decorrer do encontro, são reconhecidas dimensões sofríveis aos acompanhantes.

Conforme percebemos, são muitas as mobilizações nas relações entre dentistas e suas práticas, pacientes e acompanhantes nesse encontro. No início, o lugar das profissionais predomina no discurso; com o tempo, há descentrações diversas, com as intervenções realizadas, surgindo mais os pacientes e acompanhantes. 


\section{Primeira cena: mais profissionais, menos pacientes e acompanhantes no discurso?}

Em círculo, com a presença de sete dentistas, a primeira cena é o analista enquadrando este encontro de forma semelhante ao quarto dia: continuar a refletir sobre as relações com pacientes e acompanhantes. Parece haver um interjogo, nos movimentos grupais, entre as demandas das dentistas, muitas vezes terapêuticas, de falarem de si, queixarem-se do que quiserem em seu tempo, e a do pesquisador em doutorado de fazer uma análise institucional do discurso com objetivos definidos como proposta em seu estudo.

$\mathrm{O}$ analista mostra às odontólogas que elas verbalizaram mais de si e suas práticas do que dos pacientes e acompanhantes nos encontros e que, no atendimento odontológico, profissionais comumente não pensam sobre si e seu corpo. No deslizamento de sentidos, o analista constrói: a demanda maior das dentistas foi de falarem delas como uma busca de espaço e despressurização.

O lugar pronominal do analista varia no discurso: "eu" e "a gente". Às vezes, refletir é endereçado às dentistas ("vocês"); em outros momentos, o analista inclui-se na reflexão grupal ("a gente").

Segue um recorte discursivo elucidativo:

(Tudo bem, pessoal?)

Grupo: Tudo jóia.

(Queria começar... É... justamente pra gente refletir, continuar a refletir sobre as relacões com os pacientes e acompanhantes, tá? Só que aí eu queria assinalar alguns pontos, algumas coisas que eu achei, né? Primeiro é: eu percebi que predominou o falar sobre 0 dentista e suas práticas do que o falar sobre 0 paciente e 0 acompanhante. E vocês colocaram que, no atendimento odontológico [...] o que acontece é que muitas vezes o dentista, ele não pode pensar tanto sobre si, sobre o seu corpo [...] Aí eu queria colocar pra vocês pra... pra a gente pensar um pouquinho. Vocês acham que é por quê: "Ah, justamente no atendimento, o cliente toma muito espaço, cobra muito, puxa muito de vocês e aí no grupo a demanda maior foi falar sobre o dentista, né?" [...] O que é que vocês acham? Vocês observaram esse movimento também?)

A: A interlocução com as dentistas surge, quando Mônica toma uma parte do discurso do analista e a ratifica. Com ela, contorna-se que uma relação dentistadentista tendeu a produzir-se mais nos encontros. Confirma o que foi constatado, e não a interpretação analítica. O analista verbaliza "isso", mostrando que um campo 
de compreensão mútua tinha sido criado. $\mathrm{O}$ analista e a dentista concordam, pelo menos, em parte.

É a relação com a entidade genérica profissão que surge, quando Mônica se refere à sua dificuldade e expectativa para com o "grupo". "Hum hum" do analista dá continuidade ao fluxo associativo da dentista:

(Mônica acena que sim)

(Você observou, Mônica? Como?)

Mônica: $E$ a questão da gente tá... A gente sempre mais focava nós em relação à gente, né?

(Isso.)

Mônica: $\underline{O}$ que a gente tem em relação à profissão. [...] aí eu disse: "gracas a Deus que amanhã tenho, tenho grupo, porque eu passei por um momento horrível em relação à nossa profissão esta semana."

(Hum hum)

A: Associado ao lugar da dentista, emerge o nervosismo, e delineia-se a possibilidade de ruptura da relação com a entidade Odontologia por causa de problema que só se esclareceu (com o gestor) no decorrer do encontro. A posição da odontóloga desliza de uma experiência singular ("eu", "comigo") para uma generalização ("a gente"), quando delineia, em seu reconhecimento, gostar, não o problemático, na relação com o paciente:

Mônica: Entendeu? E ontem eu tava num estado de nervo tão grande que eu... Eu ontem pensei em largar a Odontologia. Por, pelo que aconteceu... comigo. Aí eu... $\vec{E}$ isso, é isso que acontece. Quando a gente tá com o paciente, não tem esse tipo de coisa, porque a gente... a gente tá numa coisa que a gente gosta.

(Hum hum)

A: Seriam as condições e relações de trabalho, dimensões contextuais, a que a dentista se refere como dificuldades? Há a configuração da maior problemática externamente à relação com o paciente? Tal compreensão não seria prenhe de desconhecimentos? Com o acompanhante, seria diferente? Sigamos recortes de interlocução:

Mônica: Entendeu? Não falei das maiores do paciente, mais tanto em relação ao paciente, e sim em relação à classe, ao convívio com outras pessoas. No caso, ao, ao, aos trabalhos que nós temos, aos serviços que nós prestamos. Acho que é mais o nosso [...]

Mônica: [...] é isso que em relação ao paciente. Eu até brinquei com Célia segundafeira: "Célia, ele falou também... o acompanhante. Na sexta, na segunda-feira, eu tive problema com um acompanhante." 
A: Mônica cita uma situação em que uma acompanhante falou de se sentar junto com o marido. A dentista verbaliza com um pronome possessivo: "na minha cadeira". Parece que a dentista configura uma situação de tensão entre ela, agente institucional da Odontologia, e a acompanhante na demarcação de espaços, uma relação de poder na definição do protagonista da cena. O analista mostra sua surpresa ao episódio relatado, acompanhando o movimento discursivo, conforme vemos no trecho abaixo:

Mônica: Porque o acompanhante falou pra sentar na minha cadeira junto com 0 paciente. Que isso era marido e esposa!

(Foi mesmo? E não foi criança? Foi marido e esposa?)

Mônica: Não. Marido e esposa. Quase que a esposa senta [...] com o paciente na cadeira.

(Na cadeira?)

Mônica: Pra eu atender.

A: Luara confirma, com seu exemplo, a situação mencionada de antagonismo do acompanhante. Ao paciente, é atribuído adjetivo no diminutivo, representando-o infantilizado. Reconhecemos uma distinção entre os lugares do paciente (colaborador) e da acompanhante (empecilho), bem como uma relação tensionada entre dentista e acompanhante, conforme a citação elucidativa, em que estranhamos o vocábulo "atacar" associado à mão, referido ao contato da acompanhante com o paciente:

Luara: Não, eu já vivi também um casal de namorados, não eram nem marido e mulher, namorados. Ele, eu atendendo ele. E ela do lado. Ele parecia tão calmo. E ela: "olhe, amor, ela tá fazendo isso e isso. Não se preocupe que não vai doer." E eu calada, né, olhando. Ela: "não se preocupe, não. Não vai doer, não." Ela fazia: "Ca, tá tudo bem." Era assim: ela passando tudo que eu fazia, ela passando pra ele. Ele lá calminho e ela nervosa, atacando ele, na mão.

A: O analista repete sua constatação e hipótese interpretativa de despressurização, busca de espaço, pelas dentistas no decorrer do encontro por a confirmação ter sido parcial:

(Então, eu fiquei percebendo é: "poxa, como é! Não é fácil! Precisa de um certo equilibrismo da parte, da parte de vocês, porque, às vezes, o paciente cobra, 0 paciente vai lá e interfere, não é?" E aí eu fiquei pensando: "poxa, como, é... tem uma série de questões que vocês têm que olhar." E aí no grupo vem: essa questão de falar mais do dentista, falar mais da prática odontológica [...])

Grupo: Foi.

([...] É, ou então tem paciente que cobra muito. Aí eu fiquei pensando: "será que o dentista não é tão cobrado no mundo de hoje pela clientela, pelo acompanhante e aí, na hora de um grupo como esse, o que surge é o oposto?") 
A: Bianca confirma. Em sua explicação, parece concordar com a constatação do analista (de falar mais de si), não com a hipótese interpretativa. Fica ambivalente. No movimento do dizer, ela apresenta outra explicação: nos atendimentos, ocorrem domínio e prazer. Um "até prazeroso" parece introduzir um vacilo ao gostar "lá" atribuído. "Envolvido" e "aquilo" são vocábulos que configuram nuanças ao fazer reconhecido como prazeroso.

No encontro de odontólogas, emerge que "não é mais o paciente". Há um deslizamento de paciente para "não é mais o dentinho". É falar do "nosso problema", que se multiplica em questionamento (“Quais são?”), seguido de síntese categórica: "a profissão". Em derivação: a questão social e econômica.

"Mas ali com o paciente a gente consegue dominar, a gente se envolve" configura dimensões a serem reconhecidas. Surge a adversativa "mas", contrapondo que "ali com o paciente" (nos atendimentos), dentistas ("a gente") conseguem dominar e envolver-se. As relações nos atendimentos odontológicos são delineadas como prazerosas, de domínio e envolvimento. Surge no grupo o que não dominam e reconhecem como desprazeroso em sua profissão? Acompanhemos o discurso:

Bianca: É isso que eu ia dizer. Porque lá, a gente: ah... nós somos é... Dominamos a situação. Você tá fazendo o que gosta. É até prazeroso. Tá numa... assim, envolvido com aquilo. Agora, quando a gente se encontra não é mais o paciente, não é mais 0 dentinho. Aí vamos falar do nosso problema. Quais são?

(Risadas)

Grupo: A profissão.

Dulce: $A$ profissão.

(A profissão?)

Bianca: A questão social, econômica, né?

Mônica: Tudo aquilo que a gente conversou nos outros [...] encontros.

Bianca: Mas ali com o paciente a gente consegue dominar, a gente se envolve.

(Hum hum)

A: O lugar do acompanhante é enunciado como problemático. Logo, denega-se que há resolução:

Grupo: Acompanhante...

É esse o caso, né?

Mas a gente resolve.

A: A dimensão de valorização das profissionais é a tônica. Fortalecer-se no mercado e politicamente? Mas como? Destacamos algumas citações: 
Bianca: [...] Agora quando a gente sai, quando a gente lembra: somos mal remunerados [...]

Célia: Que tá quebrando. Eu, eu... Que tá... As coisas estão, sabe?... se equiparando mais, apesar de que a gente ainda não se valorizou. Acho que a classe de Odontologia ainda não se valorizou. Porque Enfermagem se valoriza, está se valorizando muito [...]

Célia: Então, tá precisando mudar. Mas até nessa formatação do, do programa da Saúde da Família, então é isso que a gente precisa, né?... lutar. Lutar, como?

A: O analista mostra aspectos do esquecimento de dentistas e implicações à sua saúde:

(E um ponto que também é me chamou atenção foi esse: que vocês disseram que é um trabalho tão envolvente, que exige tanta concentração, que, às vezes, vocês esquecem o próprio corpo pra se dedicarem ao paciente e só vão sentir depois e que têm até prejuízos pra a saúde de vocês.)

A: Célia confirma e fala do cansaço. "A gente" "cansada" desliza para o "corpo cansa muito". "[...] eu tou entrevada" desliza para "que corpo, todo moído!" Há uma oscilação entre os registros "a gente" (comunidade odontológica), "corpo" (corpo dessubjetivado?) e "eu" (sujeito singular?) no dizer sobre a profissão que cansa, entreva e mói. Sentir é delineado, quando o trabalho é finalizado. A ordem da necessidade surge como definidora dessa situação:

Célia: Claro. Hoje eu tava tão cansada, tão can... Porque assim: vai chegando o final de semana, a gente vai ficando cansada, né? O corpo cansa muito. Aí eu, dia de terça e quinta, faço yoga, né? Tou tentando fazer academia. Aí fui pra academia hoje cansada. Não, rapaz, eu vou. Aí fui, fiz a yoga. Eu disse: "meu Deus, como eu tou entrevada! Que corpo, todo moído!" Mas assim... Da profissão da gente, da maneira da gente trabalhar, $R$, entendeu? Aí a gente cansa mesmo. Aí a gente só sente quando para e vai fazer uma atividade, alguma coisa. E quando tá trabalhando, eu acho que ninguém sente, porque... É uma necessidade.

A: Dulce associa falar de si a uma busca de identidade entre dentistas:

(Será que não é por isso que na hora que vocês se encontram vocês falam sobre vocês?)

Grupo: $E$.

Eu acho.

Dulce: Eu acho que é pra ver se a gente tá fora de foco, né?

Dulce: Será que só eu que tou assim?

(Hum hum)

A: Célia mostra que, na relação com a profissão, há decepção até com os médicos. Ela mostra vários determinantes ao lugar do profissional e de suas práticas. $\mathrm{O}$ esquecimento de si constitui-se relacionado ao excesso de trabalho e o 
verbo "vai" é seguido de reticências. Inominável aonde vão? Célia explica que tal fato é por "precisar" manter o padrão de vida:

Célia: Mas eu tou admirada, sabe com que $R$ ?

(Hã hã)

Célia: Que teve um dia desse que eu fui pra um aniversário e tinha um, um... alguns médicos e até os médicos estão decepcionados com a profissão. Eu fiquei impressionada. Tem gente que tá saindo. Tá saindo ou tá mudando pra outra profissão. Ou saindo e se envolvendo com o comércio. Eu fiquei assim. Eu digo: não acredito. Esses médicos tão conceituados tá pensando isso da profissão deles, imagine eu da minha, entendeu?

(Hum)

Célia: Eu fiquei impressionada. Sabe o que é isso? Isso tudo é o estresse, é... essa vida da gente. É essa forma de trabalho. O sistema mesmo, né? Você vai pra um hospital, dá plantão, cansa, minha gente! Isso tudo cansa pro médico também. Vida de plantão, no hospital [...]

[...] Então isso tudo, a gente vai se esquecendo, vai esquecendo de si próprio e vai... Por quê? Porque precisa manter o padrão, tem uma família, né? [...]

A: $\mathrm{Na}$ interlocução, seguem alguns dos exemplos que surgem em que as dentistas explicam por que falam mais de si nos encontros:

Célia: É. Aí vai desabafar.

Mônica: Até mesmo pra gente saber se os outros tão... achando ou sentindo a mesma coisa que a gente.

Luara: É. Senti muito isso no primeiro encontro da gente, quando eu saí. Eu disse: "Olhe, tudo que eu penso, o pessoal também pensa."

A: Bianca dá um tom de otimismo ao grupo, o que mobiliza os posicionamentos queixantes. Ela apresenta dimensões negativas do ser médico, legitimando sua escolha profissional. Adiante, ela associa acreditar a ocorrer e realizar. No encontro de dentistas, ela traz que vão ver as dificuldades. Ora ela verbaliza como "minha realidade", ora como sacrifício de "todo mundo", justificado por várias dimensões, como a econômica e a psicológica:

Bianca: Eu não gostaria de ser médica, porque eu não gosto... Meu telefone não tá no receituário como alguns colegas botam. Meu celular também não. Porque eu não quero ser incomodada. E médico tem isso, né? A depender da, da profissão dele, é incomodado. Então, eu tou satisfeita... com a minha profissão, e eu acho que a gente tem que acreditar na gente mesmo, porque o que, no que a gente acredita, é o que ocorre, né? Se eu acredito, sei lá, que eu tou realizada, que eu tou feliz ou que eu quero ter os, os meus sonhos, eu vou realizar. Eu não preciso me comparar com $A$, com $B$ ou com $C$. Eu tenho que fazer a coisa certa, que queria ter real. Essa é a minha meta. Então... Nessa hora que a gente se encontra, a gente vai ver o quê? São as dificuldades, né? Vai ver que a gente comece a debater isso. Mas eu... Assim, não é... É minha realidade, o sacrifício que todo mundo tá passando por causa da questão econômica, da... estresse, tudo. É a minha realidade. Mas eu não estou insatisfeita, 
porque eu acho que você tem seus problemas, quem é médico tem os problemas, quem é advogado tem os problemas. Todo mundo. Todo mundo tem problema [...]

A: A competição surge como necessária para vencer. Um lugar para a especialização é marcado no âmbito das pressões mercadológicas como no exemplo:

Bianca: [...] Você tem que acreditar em você e seu ideal. E ser bom, né? Se acha que tem que fazer tudo, faça. Se quer se especializar mais, procure, busque, porque só vence o melhor. Em todas as áreas [...]

A: Surge a possibilidade de ver uma saída para as dificuldades das dentistas. Bianca relativiza a posição queixante em relação à área:

Bianca: [...] Então, por que só Odontologia? É que a gente fica na, no nosso redondinho, só vendo as nossas dificuldades. A gente tem que a... que ver é a luz, é, é, é a porta. E não, sabe, o fim do túnel, o, o, o escuro. Não. Eu... O que eu quero viver, eu vou atrás. Eu tenho que... pensar alto. Eu não posso comparar a minha profissão, a Odontologia. As outras também tá ruim [...]

A: $O$ analista retoma a cena da luta do profissional na atualidade e, com base nos encontros realizados, configura uma posição das dentistas de tentar fazer a prática e existirem várias interferências/obstáculos. Ele posiciona, em sua reorganização discursiva, os lugares do profissional, do paciente e do acompanhante:

(Agora veja que aí aparece: vocês, tentando fazer a prática de vocês da melhor maneira possível, e por outro lado uma série de obstáculos. Aí vocês trouxeram: a questão econômica, essas coisas dos diferentes serviços, não é? $\mathrm{E}$ vários outros obstáculos. Às vezes, até o próprio paciente, o acompanhante que... dificulta um pouco o que vocês querem fazer, né? Mostram o dentinho que... querem que extraiam o dentinho. Então assim, como é a prática de vocês, porque vocês querem fazer 0 trabalho de vocês de uma determinada forma, mas tem uma série de interferências?)

A: Com os assentos localizados na relação triádica pelo analista, Bianca delineia que tem que saber do ser e fazer, ter consciência de si. Parece que ela configura como problemático o que escapa da relação de domínio. O dia a dia é reconhecido treinando; a inexperiência é associada a "mil apertos". A relação com o paciente é posta como um aprendizado e relação de domínio. O não fazer é associado a deixar se influenciar pelos outros na relação, como o acompanhante e o paciente. Por isso ter que saber do ser e do fazer. Produzem-se reticências e "não sei”, a dúvida em sua posição. A dentista pede a Deus poder (autoridade) e saber (sabedoria) para "lidar". "Tenho que ter o meu conhecimento e saber agir" mostra a relação com o (não) saber. "Tem que se posicionar estando do lado da profissão" configura seu reconhecimento de qual deve ser o lado da profissional nas relações, nas práticas. No momento do atendimento, as dentistas precisam saber lidar: 
Bianca: [...] Mas você tem que saber o que você é e o que você está fazendo. Tem que ter consciência de você. Então as outras coisas você tem que dominar.Tem que saber dominar. Claro que é o dia a dia que, que vai treinando a gente, né? Uma pessoa inexperiente, que é recém-formado, passa por mil apertos. Mas ali, a minha relação, eu e o paciente, é um aprendizado. E eu tenho que dominar ali, como você tem que dominar aqui. Ela lá. Assim, cada um na sua profissão. Porque se você deixar se influenciar pelos acompanhantes, pelo que o paciente quer, você não faz nada: hora nenhuma. Então, você tem que saber quem você é, o que você vai fazendo e... Não sei. Eu peço ao meu Deus autoridade e sabedoria pra lidar com aquela situação. Do mesmo jeito que se eu tiver em outra situação, eu também vou pedir, né, ter sabedoria pra lidar. Mas eu tenho que ter o meu conhecimento e saber agir, né? Tem que se posicionar estando do lado da profissão. Eu acho que essa questão de paciente é uma coisa que acontece, né? Acontece. Mas a gente tem que saber lidar na hora, não é?

A: O analista apresenta seu reconhecimento de mobilização nos encontros, compara cenas:

([...] eu tenho percebido uma mobilização, por exemplo, no início foi o discurso mais da desvalorização da área, depois [...] uma coisa de valorizar a área, de lutar, né, de transformar, não é? [...] Então eu percebi uma mobilização na maneira que vocês enxergam a própria prática no decorrer desses encontros. Então no início foi uma coisa mais do desvalorizado. Até eu acho que foi Célia que trouxe: "saí pensando um pouquinho e até comentei: a gente tá numa posição de se queixar, se queixar, mas não é bem assim." Não foi Célia?)

Célia: Exatamente.

A: Mônica, após um "não", confirma o indagado. A ambivalência da resposta parece justificar-se ao configurar sua dificuldade na luta pela valorização da profissão. O problemático é o outro? O que existe externo ao relacionamento dentista-paciente-acompanhante? Ela verbaliza que existem exceções na relação; ela inicialmente as associa ao acompanhante e posteriormente também ao paciente. Sua problemática maior (com o gestor) sinalizada no início do encontro se esclarece.

As relações e condições de trabalho destacam-se. Acompanhemos o exemplo:

(Então, eu percebi uma mobilização. Não sei se vocês também perceberam esse movimento no decorrer dos encontros. Como é que vocês veem?)

Mônica: Não, também a... também acho, R. Quando eu falei pra você a questão [...] me aconteceu nessa semana foi rela... foi relativo mais ou menos a isso. A lutar pela valorização da profissão e você ter um gestor ou outro que che... olhar pra sua cara $e$ dizer: "Eu tenho prioridades melhores do que a Odontologia." Entendeu?

(Hã hã)

Mônica: [...] Como a gente tava falando: o, o paciente se sabe lidar, não há problema. Têm algumas exceções com o acompanhante. Com o acompanhante, o paciente, mas excecõos. Aí a gente acaba se... sabendo lidar com isso. $O$ que... Por isso que a gente falou, conversa, falou mais sobre a profissão. Porque o que acontece muito com a gente é o outro, não o paciente. Mas o outro. O que o outro tá, tá, tá... falando por aí. O que o outro tá, tá, tá fazendo. Por isso essa, essa... essa tentativa de valorização da profissão que a gente tava fazendo e já chegou a falar pra, pra, na frente da gente. [...] 
"Não, ah, eu, minha prioridade é outra do que a Odontologia." E você olha pra ele e o gestor é dentista.

A: O analista faz espelhamento interrogativo. Em seguida, indaga a dentista da existência de espaços de grupo para refletir na dimensão do ensino:

(Então são essas outras dificuldades que terminam, né, sendo muito importantes? Agora é, você falou que você quis vir pra poder colocar, né, ter esse espaço do grupo. Vocês não têm esses espaços de grupo para refletir na formação, nem na pósgraduação?)

A: Bianca, do lugar atribuído, menciona que se isola. Os encontros grupais têm possibilitado uma relação dentista-dentista, fator de adesão das participantes? Sua compreensão de seu isolamento parece oscilar: é o meio, ela ou a profissão? Delineia-se que não é exclusividade sua, conforme o exemplo:

Bianca: Não, não. Isso que eu tava pensando. Eu não sei se é uma peculiaridade de Sergipe ou dos aracajuanos, porque... Eu sinto isso não só na Odontologia, em muitas áreas da minha... da minha vida, porque particularmente... eu, né, falando de mim. Porque eu sou muito, muito fechadinha no meu jardim. Sabe? Muito fechadinha. Então, se você não ligar pra mim, eu não vou ligar pra você nunca. Agora gosto de você demais. Daqui a um ano se você... ou dez anos, aí a gente... Pra mim, é como se fosse hoje. Tá entendendo? Mas eu tou muito fechadinha. E eu achava que era... só eu. Só eu. Mas não sou só eu, né? A profissão é assim [...]

A: Na ordem de rupturas do isolamento, é assinalado que bom seria se o grupo com dentistas tivesse continuidade, como no trecho discursivo:

Bianca: [...] $E$ assim esse grupo tá ótimo. Bom seria se a gente continuasse nos encontrando toda quinta ou qualquer outro dia, né?

Mas ói: teve festa de, de, de não sei quantos anos de formada. Você foi? Eu não fui também. Ah, eu nunca mais vi fulana, sei lá como é que tá e não sei o quê. $E$ vai ficando e não mais indo. Só vai aquele grupinho. Agora três pingos d'água. Tem que mudar, né? Tem que quebrar essas coisinhas. Na minha... na minha vida é isso. Não sei se na de vocês é. Mas aí...

A: $O$ analista indaga a dentista acerca de poder produzir rupturas, ao que ela responde com uma afirmativa. Empoderamento de seu lugar? Afastamento de uma posição queixante com Bianca? O analista é posto como alguém externo à cena que possibilita o encontro de dentistas e que consigam falar, sendo que inicialmente Bianca reconhece que emergem os problemas, como vemos no recorte discursivo:

(Então pode quebrar coisinhas?)

Bianca: Pode!

(Risadas)

Bianca: $E$ aí como a gente fica com isso, só se encontra assim, quando alquém de fora: "ói, você pode, porque eu vou fazer meu trabalho?" "Vamo, vamo." E aí a gente consegue falar, né? Aí só fala dos problemas primeiro, não é?

(Risadas) 
A: Adiante, o analista mostra, sob a forma de pergunta, que surgiram no discurso, durante os encontros, termos da Economia, marcando a dimensão da sobrevivência. Bianca contorna que tal aspecto não é exclusividade delas e que a tomam como se fosse. Ela verbaliza inicialmente dividir os problemas; no deslizamento associativo, há a inclusão, na divisão, do bônus. Emerge uma imagem de perda de limites:

(Hum hum. Agora inclusive é... teve um momento do grupo que vocês falaram muito de termos como orçamento, cobrar, investir, que são termos da Economia, não é? Então, era como se essa questão da sobrevivência, da Economia, né, tivesse aí o tempo inteiro, né, circulando pelo grupo, não é? Não sei se vocês perceberam...?)

Bianca: $E$ é uma coisa que a gente toma pra gente, mas também não é só nossa.

(Hum hum)

Bianca: Não é só nossa!

(Hum hum)

Bianca: Né? [...]

(Hã hã)

Bianca: Né?

(Hã hã)

Bianca: [...] Odontologia é por opção.

(Hã hã)

Bianca: Então, vamos dividir todos os problemas.

(Hã hã)

(Risadas)

Bianca: Todos! Os... os bô... o ônus e o bônus. Aí a gente, né, acostumado a trabalhar, trabalhar que se preocupa demais com tudo, com tudo, com tudo [...] não precisa pagar tudo, comprar tudo, fazer tudo, não. Tem que ter um limite. Eu acho que às vezes a gente perde os nossos limites. Em todos os aspectos.

A: O analista faz um link, em forma predominantemente questionadora, da perda dos limites das dentistas com seu esquecimento de dimensões de si:

(Perde os próprios limites, não é?)

Bianca: É.

(Foi o que vocês disseram, né, esquecem o próprio corpo, né? Esque... esquecem o que estão sentindo, não é? É tão envolvente que esquecem tempo.)

A: Bianca questiona a situação configurada, mobilizando a dinâmica discursiva. "Você não precisa se matar de, de trabalhar" retira tal situação mortífera do campo naturalizante da necessidade? "Você é que tem que achar" seria uma mobilização 
da posição da dentista, uma localização de limites? A questão de quem é o mandante é central. O sujeito emerge fazendo o que pode, dentro do limite:

Bianca: Na realidade, não é isso. Na realidade, isso é uma mentira, porque você não precisa se matar de, de trabalhar. Você não precisa se magoar, porque o gestor acha que a Odontologia não é importante. Você é que tem que achar. Você tem que fazer o que é certo, ele ache ou se... se ele não achar, problema dele [...] Eu vou fazendo o que eu posso. Dentro do limite, tudo bem.

A: Há uma marcação da variável experiência por Dulce. O analista faz deslizar o termo em um questionamento diretivo que abre pouco a cadeia discursiva:

Dulce: Mas aí tem a questão de experiência, né?

(Hum hum)

Dulce: Da profissão [...]

(Você acha que diminui a ansiedade?)

Grupo: Muito.

(Com a experiência? Bastante?)

Grupo: Diminui esses nossos...

A: Querer abandonar a profissão constitui-se relacionado à chefia, às dificuldades. O fazer odontológico, por outro lado, é associado a gostar:

Manuela: E essa questão de chefia... querer desistir. Eu quis desistir, acho que semana retrasada. A gente pensa em muitos momentos: "ah, eu quero desistir. Eu vou abandonar tudo."

(Hum hum)

Manuela: $E$ aí a gente para, pensa: "poxa, é... É o que eu gosto de fazer. Por que é que eu vou abandonar?" Mas a gente sente em muitos momentos.

(Quando se depara com as dificuldades, não é?)

Manuela: Quando se depara com as dificuldades.

A: A posição da chefia/lei é criticada pela dentista. Desenha-se um movimento na relação de poder:

Bianca: Essa questão de chefia é outro, outro, outro detalhe [...] tem que ter equilíbrio, maturidade, porque parece que eles esquecem a questão... é... que um dia, né, foi peão, né, que tava lá trabalhando. Quando chega lá: "não, tem que ser assim" [...]

A: Surge insegurança da dentista, mesmo "investindo" em si, como no exemplo:

Manuela: Mesmo que você... tenha consciência de que você fez uma faculdade boa. Mesmo que você tenha consciência de que você fez uma especializa, está fazendo, está investindo em você, têm horas que você se sente: "poxa, será que eu sou isso tudo mesmo que eu acho que eu sou? Será que eu realmente tenho condições de contornar esse problema?" 
A: Em resposta à indagação de Manuela, os encontros grupais delineiam-se como lugar de identificação, valorização, aprendizado e troca de experiências. Apresentaremos uma interlocução ilustrativa:

Bianca: E tem!

Manuela: Tem. Só que a gente precisa sa... a gente precisa achar isso.

Bianca: Sabe onde é que a gente acha? Nessas rodinhas! [...]

Manuela: De saber que a gente não é o único [...]

Bianca: [...] Um nada. E que você passou por essa experiência. E que eu agi assim nessa outra. E que ela tomou uma certa atitude. É aqui nessa rodinha que a gente aprende as coisas.

(Quando vocês trocam experiências?)

Bianca: Quando troca experiências.

Manuela: Só que a gente troca essas experiências às vezes... Nós aqui não nos conhecemos, trocamos essa experiência. Mas eu particularmente tenho só amigas dentistas e não troco essa experiência com elas [...]

A: Surge um antagonismo entre mostrar e ser:

Bianca: Mostrar uma coisa que não é, não é? Mas é porque também isso foi roubado da gente, né? É, é, esse tipo de amizade, essa conversa franca. Quando se... se reúne é só estrela, né?

Célia: $E$ cada um a estrela mais linda, né?

Manuela: E tem problema no consultório, né?

Bianca: Tem problema. Tudo isso. No caminho. E não é essa realidade.

A: Diferenças são indicadas nas relações entre colegas e professor-aluno, o que ilustraremos com algumas frases:

Dulce: [...] Eu ligava pra L. "L, como é que eu faço isso, isso, isso e isso?" [...]

Manuela: É. É a concorrência.

Bianca: Medo. Ou então eu não posso dizer a ela que é a resina que eu uso, porque se não ela vai usar e vai ser melhor do que eu [...]

Manuela: [...] Você faz especializacão, né, com X, se você tiver dificuldade, você leva o seu paciente pra lá e ele lhe ajuda.

Bianca: [...] Porque as, as pessoas que sabem o que são, enfim... o que são, o que representam, elas não têm medo de ensinar nada [...]

A: Constitui-se, na interlocução, romper relacionado a procurar grupos, opinião de colegas, ao que o analista traduz como sair do individual pra relação. A relação com o saber/poder nos parece outra. Vejamos o recorte discursivo:

Dulce: [...] Então a gente tem que começar a quebrar isso. E procurar grupos. Eu tenho casos que eu faria isso. Mas eu preciso... opinião das colegas [...]

(Vocês estão falando de sair do individual pra relação.) 
Bianca: Pra relação.

\section{Segunda cena: 0 analista no lugar de dentista}

A: $O$ analista coloca-se, na estratégia de manejo da transferência, que se sentiu "como um dentista", pois a ele eram endereçadas pelas odontólogas solicitações e como concluir/resolver as problemáticas delas; e elas mesmas se posicionavam como uma clientela que lhe concedia mais tempo (diferente daquela com a qual lidavam).

A hipótese do analista é que as dentistas, na suposição de saber a ele, o posicionam para resolver os problemas delas, o que busca que reflitam com seu dizer que põe em destaque cenográfico a relação dentista-clientela no manejo transferencial:

(Hã. Eu, eu... Outro ponto assim que eu observei: ah... teve uma hora que vocês [...] abriram, né, tantos aspectos da vida, é, profissional de vocês que até vocês colocaram... Acho que foi até você, Célia, que colocou: "a gente tá, é, trazendo tantas coisas, não sei como é que você vai dar conta [...]")

Célia: [...] Vai dar um nó na sua cabeça.

(Foi você que disse: "vai dar um nó na sua cabeça". Eu me senti, Célia, nesse momento como um, como um dentista entre aspas.)

Célia: Hum hum.

(Porque como se vocês tivessem tantas coisas. Não é um aspecto. Não é o paciente. É o paciente, é o acompanhante, é, é a ficha clínica. É isso, é aquilo. E eu me senti como se fosse, né, um dentista e com tantas solicitações.)

(Risadas)

(Com tanta coisa aberta, né?)

(Risadas)

(“E aí agora, como é que vai dar conta? Como é que vai concluir?")

Bianca: Pronto.

(E você até disse: "a gente dá mais tempo pra você." Aí eu disse [pensei]: "ah, que clientela boazinha, né?")

A: Em encadeamento associativo, Dulce refere-se à sua busca de um portavoz para os dentistas em eleição. Manuela é quem mais dá o tom ao dizer do analista: "Você gostou de ser dentista?" Ela cutuca o analista que tanto as cutucou 
neste encontro. Sucedem posicionamentos e risadas que esboçam a complicação da situação "em vários níveis". O analista legitima a dificuldade da situação odontológica que as dentistas apresentam e mostra que Célia configurou o grupo com um aspecto terapêutico, desenhado como relação analista-clientela, clientela esta que dá mais tempo ao profissional. O trabalho analítico é realizado na dimensão da transferência e em suas ambiguidades:

Dulce: Quando tava perto das eleições, eu disse: "quem é que eu vou votar pra vereador que eu não tenho ninguém? Vou procurar um dentista" [...]

Manuela: "Você gostou de ser dentista?"

(Ah! Não, uma situação...)

(Risadas)

Grupo: É complicada, não é?

([...] é, até na hora Célia [...]: "é como um desabafo, um... tem um aspecto até terapêutico", né? Então, vocês se colocaram como clientela e me colocaram como profissional. E aí, como clientela, você disse: "se precisar de mais tempo... pra resolver tanta coisa." Aí eu disse [pensei]: "como deve ser difícil pro dentista resolver com pouco... É, é, os pacientes cobrando por causa de tempo, por causa disso.")

A: Com a adoção do não e/ou denegação na gramática discursiva, o gostoso da profissão é defendido e relacionado à novidade, emoção, inexatidão, dificuldade e à diferença. Ele é associado a desafio, vitória e estímulo:

Bianca: Aí é que tá o gostoso da profissão. Eu acho que não queria outra coisa, justamente porque não ia ter novidade, não ia ter emoção. Eu tava falando hoje: "Matemática é exato." Eu, eu num suporto Matemática, justamente porque é fácil demais. Matemática não tem... Não tem diferença [...] O gostoso é isso. Pra mim, é, é tar sempre no desafio. Sempre vencendo. É estímulo. Pra mim, é. É estimulante. Agora aquela coisinha: nhem, nhem, nhem, não dá pra mim. Não dá.

A: Célia confirma o posicionamento de Bianca, generalizando a dimensão de desafio à área de saúde. Ela menciona a unicidade do paciente, ao que Dulce acrescenta a do dente. A interlocução, no encontro, passa a ser sobre a diferença do paciente no que novamente há um deslizamento discursivo para "o dentinho", sendo reposta a oposição da relação dentista-paciente à dimensão dentária (o dente diferente, antagonista). Quem é a clientela? O paciente? A "diferença" delineia-se como "o gostoso":

Célia: É, eu acho que a área de saúde é, é, é um desafio.

Bianca: $E^{\text {. }}$

Célia: $A$ área de saúde como um todo. Porque você pega um paciente, aquele paciente é único.

Bianca: $E^{.}$ 
Dulce: E cada dente também.

Célia: Entendeu? Você pode até fazer o mesmo dente, a mesma... preparar a mesma cavidade, tudo, mas é um paciente diferente.

Bianca: Diferente.

Célia: Cada um com sua história. Cada um com sua vida.

Bianca: $E$ até... até o dentinho do, do mesmo paciente é diferente do outro. É tudo. É também o, o... né, o antagonista. Você vai. É completamente, então... $\underline{O}$ gostoso é isso $[\ldots]$

A: Na ressignificação das diferenças, Dulce exemplifica com incômodo uma situação peculiar pela qual passou com sua atendente na distribuição assimétrica de pacientes em dois dias. O questionamento emerge posteriormente ao atendimento da clientela. O lugar do profissional é problematizado em movimento discursivo, conforme o recorte do discurso abaixo:

Dulce: [...] Eu disse: "o que passou na cabeça dela?" Aí eu parei tudo e pensei o que passou na cabeça dela, que passou vinte ni um dia e dois no outro.

(Rã rã rã)

Dulce: [...] Acha que a gente é máquina. Num cansa. O que é que foi que aconteceu? $E$ nem tempo de conversar eu tive, porque disse: "não, dois no outro dia, vou me embora. Vou dormir na minha cama." E os braços no outro dia! Quando eu cheguei em casa, eu disse: "ói, eu acho que eu estou cansada. Os braços, a coluna e tudo."

(“Eu acho!" em tom de humor)

Dulce: [...] E nem tive tempo de questionar e perguntar. Porque se eu que... eu não ia atender. E o povo lá, reclama, né? ... Porque... Aí depois, quando eu fui embora, é que eu comecei a questionar [...]

A: Produz-se, na interlocução, uma profissional a defender seu espaço da auxiliar e clientela, como na citação:

Bianca: Deixa os outros fazerem. Dei... deixa, deixa, deixa, sabe? Eu... Às vezes eu pego assim: nesse, nesse ponto. Vou deixando isso uma vez. Deixo e... tá... Quando eu vejo, já tomou conta e a própria clientela. Não, é o contrário! É o contrário! Ela é que tem que fazer, né, a ...

A: O analista mostra o que reconhece (fazer odontológico no paciente) e reapresenta uma faceta atribuída no decorrer dos encontros ao esquecimento, que é a concentração, fazendo relação interpretativa:

([...] vocês fazem o trabalho de vocês no paciente e aí tem a concentração que vocês terminam esquecendo de vocês, porque têm que se concentrar muito, não é? E que só vão sentir a dor, né, as coisas depois, né? E...)

A: Bianca questiona a ideia de não se sentir trabalhando. Posteriormente, a relação entre sentir e atender mostra a ambiguidade de sentidos, as distinções do dito para o dizer no giro da enunciação: 
Bianca: Quem não é que se sente trabalhando? Não tá tão bom? [...] Não é verdade? Porque assim: você só sente a dor depois que você não atende. Você só... É tão bom ali que você esquece.

A: Célia estabelece a Odontologia acabando com o profissional. Bianca e Célia travam um debate, marcando diferentes posições, conforme os exemplos:

Célia: [...] Não, até a gente ajeita aqui, ajeita ali, esse tipo de, de, mas a Odontologia é uma profissão que acaba com a pessoa, é [...]

Bianca: Mas têm outras coisas também que acabam com a pessoa [...]

A: Bianca configura o grupo com dentistas como uma fogueira para se ajudarem. Relação calorosa que falta até em alguns vínculos de amizade? A visibilidade de que ela não está só, é normal/acontece o que passa, não apenas com dentistas, é ressaltada. Surge o analista mobilizando o olhar da dentista:

Bianca: É. Porque assim, quando você começa: ai... Pra mim, essa rodinha... Essa rodinha, que eu falei, né, porque pra mim é uma fogueira que a gente tá... se ajudando uma a outra. Pra mim, isso falta até em algumas amigas. Eu estou vendo que eu não estou sozinha, que é normal e que acontece, não só com as minhas colegas de profissão, como também com as outras profissões, porque eu vou olhar pra um lado $e$ $\underline{R \text { não }[\cdots]}$

Terceira cena: as dentistas nos lugares de pacientes, acompanhantes e psicólogo

A: Na terceira cena, ocorrem muitas mobilizações discursivas. Inicialmente, o analista, após apontar para determinados movimentos no discurso das dentistas, instaura uma nova cena, indagando-Ihes o que acontece do lado do paciente e acompanhante. Há um timing para elas se reposicionarem na interlocução:

(E, e... Vejam o seguinte: é, também percebi, é, um movimento, até em relação à questão do cobrar. No início, era: como é difícil cobrar [...] Foi havendo, né, um deslizamento nesse sentido também; do cobrar, que era difícil pra alguns, depois virou cobrança do próprio paciente em relação a vocês, não é? Como eles, é, cobram, às vezes, é, dificultam alguma coisa [...] E como vocês tentam, não é, lidar e nem sempre o paciente quer o trabalho de vocês. Isso terminou sendo percebido por mim. Por que será que é difícil pro paciente, né, aceitar o trabalho de vocês em alguns momentos?)

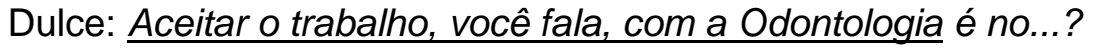

(Isso, porque, às vezes, o paciente, vocês trouxeram que ele dificulta, né, que atrapalha. Ou o acompanhante. Qual, o que é que acontece no lado do paciente, né, do cliente, do paciente e do acompanhante?)

Bianca: Em questão de preço? De cobrar muito? 
Mônica: [...] Ao tratamento. $\underline{\text { Ao tratamento. }}$

([...] Em relação ao atendimento. É, o que é que acontece pra eles, às vezes, assumirem essa postura que dificulta?)

A: Citaremos alguns exemplos que mostram a dificuldade no lugar da clientela, e as dentistas vendo-se na posição de paciente. Sujeito e dente identificam-se em "comecei a doer":

Mônica: Eu acho. Eu acho muito que é assim. Em relação à questão da dor, quanto mais evitar que ele faça algum tipo de tratamento, porque ele não vai causar dor. Todo mundo tem medo daquele... do motorzinho. Tanto que qualquer paciente que chega no consultório, vem: "ah, ah... você tá tão sofisticado, tão modernizado e até hoje não inventaram um, um, um... um aparelho que não fizesse esse barulhinho." Não é nem, nem... Não é nem de tocar. O barulho já incomoda ele.

Mônica: Não vamos dizer que o tratamento odontológico é tratamento sem dor que não é.

Célia: Eu mesmo não gosto de tratar o meu dente.

Célia: Não [...] E a gente que é dentista sabe cada coisa que tá fazendo, né? Aí eu: "ai, meu Deus, agora vai lá, na dentina. Pronto, comecei a doer." Não, eu fico... Eu fico em pânico.

Dulce: Quando a gente passa pela dor, a gente não aguenta mais.

Dulce: E estimular pra ir pra Ortodontia. Repare. Tem que passar três anos com o aparelho.

Carla: Não, não. Têm condutas...

Mônica: Aí eles não querem. Quem que quer sentir dor?

A: Chama-nos atenção "vou assim chegando na boca do paciente". É o dentista ou sua mão que vai à cavidade oral da clientela? A profissional e sua mão identificam-se no exemplo:

Luara: A gente usa um acidozinho que ele vem numa embalagem com uma seringazinha. Eu já passei tanto constrangimento com aquele ácido que, quando eu vou assim chegando na boca do paciente com aquilo na mão, o paciente dá um pulo: "não, anestesia, não. Não sei o quê". "Não, não é anestesia, não." Eu vou pedir pra mudarem a embalagem daquele negócio.

A: Surge um lugar para o dentista trabalhar aliado ao psicólogo ou ser um pouco psicólogo. Há uma descentração dos lugares no discurso, conforme as citações:

Dulce: Muitas vezes, a gente tinha que trabalhar até esse lado com o psicólogo. Passar da, da sala da gente direto pro psicólogo. Aí, isso seria o ideal!

Carla: Às vezes, a gente também tem que ser um pouco de psicólogo também.

Mônica: Porque tem, tem esse lado. Têm muitos pacientes que veem na gente um tanto um psicólogo. Vai, fala da vida. 
A: As dentistas são indagadas pelo analista sobre as dificuldades das vivências dos acompanhantes no atendimento odontológico:

( $E$ do acompanhante, vocês acham que também têm aspectos difíceis que o acompanhante tem que lidar?)

A: Alguns exemplos elucidativos que mostram a complexidade da relação triádica na Odontologia seguem:

Mônica: Eu acho que o, o acompanhante, às vezes, fica difícil pelo que 0 acompanhante já sofreu no dentista, aí pensa que...

Luara: Quem está acompanhando é mais medroso do que o paciente.

A: $O$ analista pergunta às dentistas de fatos mais marcantes na relação com paciente e acompanhante:

([...] Vocês têm fatos assim que é, marcaram mais ou mobilizaram mais vocês, que vocês pudessem contar, é, na relação com o paciente e o acompanhante, né? [...])

A: Surgem vários exemplos, como:

Manuela: Eu tive uma relação com um paciente. Ele tinha chegado lá e... e a queixa principal dela era que o dente estava encolhendo [...]

Dulce: Foi um, um senhor já de oitenta anos. Chegou lá, aí pra fazer uma limpeza. Uma limpeza, porque tava... um tanto mal. Ele já não guentava mais... abrir a boca. $E$ a filha tava do lado dele. Disse: "ói, filha, faça aí uma limpeza por favor, porque ele não está comendo mais, não" [...] Quando eu abri a boca e comecei a limpar, eu disse... Eu fiquei assim. Eu digo: primeiro que vermelha, corei toda. [...] "Como é que eu faço?" Cheio de bichinho de mosca [...] Já tava um caso, né? Acho que já tava necrose mesmo. Aí me deixou realmente de jeito. Eu fiquei pensativa. Pensativa. Eu disse: "nossa, a gente não é nada. Nada, nada. Um pedaço de carne." Se não tomar cuidado, né? [...]

A: O analista assinala o medo, a insegurança, do dentista, aspectos que apareceram aos poucos no grupo. No início, o medo era configurado no paciente. Surgimento de outra visibilidade das dentistas de si mesmas? É marcada "a falta de receita de bolo", como vemos no recorte discursivo:

([...] no início, o medo do paciente, mas também vocês foram colocando aos poucos no grupo que o dentista, às vezes, passa por situações que geram medo, geram insegurança ou mexem com questões, né?)

Manuela: É, é, é a fal... a falta da receita de bolo. Não existe. Você vai pegar o paciente e você vai fazer aquilo e vai dar cem por cento.

A: Surge o perder o controle da relação com o paciente, bem como o não saber por quê, como na citação:

Manuela: E a gente vivencia bastante isso. Que aplicava os mesmos procedimentos. Eu acho que em Ortodontia isso também é bem marcante; aplicar o mesmo procedimento em vários pacientes e você perder o controle em determinado paciente. E você não saber por quê. Não encontrar. 
A: $O$ analista relaciona a formação em Odontologia com falta de (in)formação e prática, lembrando o que já disseram. Manuela sinaliza uma lacuna no como fazer. Ela configura ainda, na relação entre dentista e paciente, a dificuldade daquele de verbalizar que não sabe fazer. Dulce justifica, argumentando que não há compreensão da clientela de tal posicionamento:

( $E$ vocês trouxeram também que, às vezes, até a... na formação, na faculdade, nos lugares onde se aprende a respeito da área é... têm questões que vocês não veem, não é? E que vocês terminam tendo dificuldade prática, como cobrar ou...)

Manuela: $\underline{\text { Como fazer? }}$

(Como fazer?)

Manuela: $E$, às vezes, assim: você dizer ao paciente que não sabe fazer é difícil [ [...]

Dulce: Eles não entendem, não [...]

A: O passado é associado a fazer tudo, como no exemplo:

Bianca: [...] Antigamente você tinha que fazer: fazer prótese, extrair dentes e tudo, está na questão da profissão. Até hoje a gente se depara com as especialidades e estranha. Aí questiona.

A: Sobre situações marcantes, Bianca mostra uma ambivalência a respeito de quem é vulnerável, como vimos em recortes discursivos anteriores (a boca do senhor de oitenta anos paralisou outra dentista) e veremos abaixo. $O$ adágio popular é posicionado de forma invertida? Em vez de "a melhor defesa é o ataque" surge "o melhor ataque é a defesa"? "Você já chega" (quem?) desliza para "eles já chegam intimidando" (referente à clientela), no sentido comum ao adágio (ataque como defesa), por exemplo, colocando o dentista contra a parede? Quem se defende no ataque: o dentista no sentido invertido do adágio? Não sabemos. Parece, contudo, que a cena da relação que se delineia entre paciente e dentista é de uma luta e há troca de posições:

Bianca: Já porque é aquela história. É... é... Tem um, um adágio popular, né, que, que "o melhor ataque é a defesa", não é isso? Você já chega... Então eles já chegam intimidando. Ele olha a qualidade da situação. Ele já lhe coloca contra a parede.

A: Surge um exemplo de um paciente policial, símbolo de força, que reclamou/discutiu/gritou com o atraso da dentista e, na "cadeira dela" (dispositivo institucional de poder, extensão do lugar da profissional), ficou tremendo e suando. Domínio corporal? "Quando a gente saiu da cadeira" mostra o grau de identificação da dentista com a paciente. Com a presença da dentista, em seu reconhecimento, não era mais o paciente o "dono da situação", mas alguém à disposição da dentista, vulnerável, com a boca aberta, sentado, não podendo fazer nada: 
Bianca: E, no início, uma vez eu tive um caso de policial, porque de vez em quando eu atendo, eu atendo policial lá. E ele: uma vez que eu cheguei atrasada e ele reclamou, discutiu, gritou e foi, ni, ni, lá em cima. Quando sentou na minha cadeira, ele ficou tremendo. Sendo que parecia que tinha Parkson.Tremia, tremia. Suava. Quando a gente saiu da cadeira, a atendente limpou. Quer dizer: enquanto eu, eu não estava, ele era o dono da situação, não é? Pou, reclama. Quando eu cheguei pra fazer o trabalho, ele ficou à minha disposição, né, vulnerável. Eu era que era a dona da situação. Com a boca aberta, sentado, não podia fazer nada [...]]

A: Um cliente surge em posição de ataque, pondo sua arma de trabalho/agressividade ("o revólver") no campo de visibilidade da dentista. A dentista, por um ato de vontade, que nega sua presença, a deixa "invisível". Emerge, neste momento, o sentido comum do adágio: "a melhor defesa é o ataque". A clientela está em posição de ataque. Os dentistas ("a gente") são representados expostos (em defesa?) na situação. "Mansinha" e "pequenininha" são associados à odontóloga. É a clientela que amedronta (quer amedrontar) a agente institucional ou, então, "sabe tudo" na mobilização dos lugares discursivos. A vulnerabilidade perpassa os dois lados da relação dentista-clientela:

Bianca: $E$ outro foi essa questão que eu lembrei do ataque. É que o policial - ele chegou, tirou o revólver e botou bem assim. Né? Pra eu ver. Vocês viram? Nem eu! Ente... Entendeu? Então... ele... a, a, a... A melhor defesa é o ataque. Então eles já chegam querendo atacar. A gente se expõe ali, mansinha. Pequenininha. Eles querem amedrontar, né? Ou então sabe tudo, né? [...]

A: No relacionamento com o paciente, a dentista busca o comando? Ela está diante de uma extração, um canal. No segundo encontro, ficou sem completar diante do que a dentista estava em sua demanda de fortalecimento. O objeto institucional da Odontologia nos parece no grupo, sobretudo, o tratamento odontológico (o da Análise Institucional do Discurso, as relações institucionais; por isso, provavelmente, nosso trabalho analítico se produz em uma zona intermediária movediça, com escapes e hiâncias, nas interlocuções e transferências entre essas duas instituições):

Bianca: [...] Mas se você se impor também, mostrar o lugar dele: "epa, que a dentista sou eu." "Eu sei." Cada um vai saber aí como fazer isso, né, porque isso é um dia após o outro que a gente aprende, não vai ter problema [...] Eu tou em frente a uma extração, canal, é isso que eu vou fazer, o resto, problema dele. E outro...

A: Surgem defesa e vulnerabilidade da clientela na Odontologia. Há uma aproximação da relação dentista e paciente com a do ginecologista com esta, quando a profissional se coloca no lugar de cliente. Não ser dono da situação/relaxar é identificado ao paciente na Odontologia. Uma relação de confiança surge como 
possibilidade de ele "se abrir", deixar fazer e começar o trabalho. Quanto tal dizer se refere também à transferência com a análise?

( $E$ você trouxe que é, no fundo, ele tava se defendendo, então tinha algo vulnerável nele?)

Bianca: Se defendendo. Muito vulnerável. Muito. Eu não suporto ginecologista. Não suporto. Porque eu me sinto muito vulnerável [...] Dentista é a mesma coisa. Quem vai pro dentista que se acha o do... o dono da situação? Ninguém. Não tem como você ficar lá, relaxar. Ela fala em mim, eu começo a aperrear [...] É uma vulnerabilidade muito grande. Então, a pessoa num, num, num, num consegue relaxar, né? Daí eu, eu assim procurar sempre é... uma relação de confiança, né? Porque se eu confio em você, eu me abro, eu deixo você fazer, porque eu tou confiando. Se eu não confio, adianta começar o trabalho? Não adianta.

A: Surge um exemplo da acompanhante (terceiro) não deixar o paciente falar, ao que a dentista intercepta. A dentista, então, cita um exemplo próprio numa urgência hospitalar em que o médico, que a examinou, posicionou-a no lugar de quem fala sobre o que sente. Dor, vulnerabilidade e sofrimento configuram o lugar de cliente e uma relação de confiança surge como possibilidade de saber/fazer:

Bianca: Eu uma... Eu, eu já lhe contei que atendi um senhor, que ele era chinês, e a mulher nem deixou o pobre do homem falar, né?[...] "Ai, porque não vai doer." Eu: "não!" O pa... saiu do jeito que entrou. Eu vou fazer uma coisa que a pessoa... O paciente que é quem vai sentir dor, quem... num diz nada. Eu vou confiar no terceiro? Mas lembro que quando eu tive um, um pouco de dor. Fiquei no [nome do hospital]. Estava lá na Urgência. E o médico queria me examinar. Eu... O meu médico, ele aí disse: "não, não, não, não. Dona Bianca, você tem que falar. E eu tenho que te examinar. Você é bebê? Eu vou perguntar à, à sua mãe o que você tá sentindo. Como é que eu vou te examinar sem saber o que você tá sentindo? Né?" [...] É dor, é vulnerabilidade, você tá sofrendo, mas tem que ter essa relação de confiança, se não como é que eu vou saber, o que eu vou fazer [...]

A: Dulce relata um caso em que se achou péssima, porque a paciente não deixava que ela fizesse o procedimento. Ela não conseguiu traduzir a dor da cliente para "contornar". A dentista fala: "não consegui fazer nada", conforme o recorte discursivo abaixo:

Dulce: [...] teve um caso essa semana que eu me achei... Me achei péssima. Ela chegou com dor, ói. Eu vi se tinha o que fazer pra tirar da dor, né? [...] ela não deixava. E dizia que tava dando choque. Eu: "meu Deus, o que é dar choque? Boca inflamada dá choque? O que é dar choque?" Não tava conseguindo traduzir a dor dela pra contornar [...]

Dulce: Adulta, vinte e três anos. Eu disse: "não estou conseguindo controlar nem o emocional dela. O que é que eu faço?" Me achei péssima, né? Me achei péssima. Três sessões e eu não consegui fazer nada. Nem o teto eu consegui. Tinha teto ainda pra eu começar. E eu não consegui [...]

A: O analista questiona seu "fazer nada". A dentista relata que encaminhou a cliente; aquela se reconhecia "enrolando" esta. Por não realizar o procedimento 
odontológico? Mas o trabalho com a relação não faz parte de uma atenção legitimada a profissionais da área? Tentar comunicar-se com quem atende já não é um fazer? Será que este não é um dos motivos, junto com a evidência do "contexto de trabalho odontológico" falar bem alto entre as dentistas deste estudo, e de suas demandas terapêuticas também, entre outros, de elas não verbalizarem tanto dos pacientes e acompanhantes como de si próprias: a especificidade depreendida do objeto institucional da Odontologia? Com esforço, houve a consecução do tratamento:

(Mas você interagiu com ela?)

Dulce: Tentei.

(Então, por que você não fez nada?)

Grupo: É.

Dulce: Aí eu disse: "eu vou passar." Passei. Passei pra L. Três sessões num radicular, e eu não tinha feito! Eu disse: "pronto." E eu tava me achando enrolando o paciente. Aí eu: "L, tome." Ela fez: "ela vai chorar". Na cadeira de L, chorou do mesmo jeito. L disse: "você já tinha me dito tudo. Eu nem liguei. Ela sentiu dor. Chorou que se acabou."

A: Achar-se péssima é relacionado a não conseguir, não terminar e controlar:

Dulce: Só que eu não consegui. Quer dizer: talvez eu poderia mudar a conduta, deixar ela chorar, mas eu não consegui. Me achei péssima. Péssima. Péssima.

(Por que péssima?)

Dulce: Porque não consegui terminar. Um canal. Não controlei.

(Mas isso não acontece?)

Dulce: É. Aí eu percebo o outro lado ruim que aconteceu, né?

\section{Quarta cena: a finalização do encontro}

A: $O$ analista anuncia a finalização do encontro, o que se imbrica com a dificuldade de terminar um atendimento odontológico citada anteriormente por Dulce. Ele sinaliza a mobilização do dizer das dentistas, de modo que se produzem os dois lados da vulnerabilidade na relação: o da clientela e o das profissionais. $O$ termo finalizar desliza com o analista que lembra o último encontro, posicionando-se como "a gente" e com reticências: 
(Agora vejam. É... A gente já tá na hora de... finalizar. Eh! Mas vocês tão trazendo um outro lado do paciente hoje, não é? Um paciente que também fica vulnerável, que sente dor, é, que fica com a boca aberta, não é? Têm uma série de coisas que vocês tão trazendo também do paciente e de como às vezes essa, essa dor do outro, do paciente toca em vocês, né? [...] Queria combinar com vocês o seguinte: a gente tem mais um encontro nosso pra gente tá fazendo uma... né? É. Finalizar.)

A: Pelas dentistas, é atribuído concluir ao analista que devolve a atribuição àquelas, em tom de humor, fazendo analogia, sob a forma de indagação, com o modo delas finalizarem o atendimento odontológico. Seguem-se risadas e um comentário de uma dentista expressivo que sugere a dificuldade do término.

Há uma situação em que os lugares se propõem intercambiar. Isto é e não é aceito ao mesmo tempo. O finalizar faz-se compartilhado. Na transferência, mostrase uma finalização possível:

Bianca: Quero ver o que você vai finalizar.

(Risadas nossas)

Bianca: Ou como você vai finalizar.

(Risadas nossas)

Célia: Como?! Como?!

(Como é que vocês finalizam?)

(Muitas risadas)

Bianca: Bom se fosse fácil, que não é!

(Risadas)

A: Ocorrem os acertos finais deste encontro para a próxima data, bem como as despedidas.

\subsection{O sexto dia do grupo com dentistas}

O último dia de grupo tem duas cenas fundamentais. A primeira cena constituise como os sentidos do término. A segunda, produzindo o (des)enlace final, delineiase como interlocuções entre pesquisador e participantes da pesquisa.

O lugar do analista é entrecruzado com o do pesquisador. O analista reendereça o indagado a ele às dentistas, já, na posição de pesquisador, faz os esclarecimentos que reconhece como legítimos às participantes da pesquisa. 
O analista investiga, provoca falas, mostra aspectos/mobilizações discursivas e constrói sentidos interpretativos ao que escuta. A sua postura é próxima e, neste último dia, o tempo verbal que adota com frequência muda para o passado. Terminar, limite e falta são termos lançados pelo analista que têm força nas interlocuções com desdobramentos nas falas das dentistas. Finalizar os encontros é manejado: o analista faz um link interpretativo com a condução e o término do atendimento odontológico. É o trabalho de análise institucional do discurso na transferência, tendo uma visibilidade ímpar.

Nos encontros, houve uma referência frequente das odontólogas ao analista como professor. Suposição transferencial de saber? Tal lugar atribuído ao mesmo, a força que se produziu nas relações entre as dentistas e a atenção do analista às demandas das profissionais participantes durante todo o trabalho nos parecem condições produtoras de adesão destas ao grupo. A falta de um docente no grupo, delineada por uma dentista, chama-nos atenção, pois indica que, se houve a ausência de um professor no grupo, o analista exerceu a sua função.

O analista/pesquisador situa-se no trabalho com a polifonia à mostra, com a qual as dentistas se deparam, ele também, e os pedidos de socorro à constituição de uma unidade imaginária no discurso por meio de suturas nas divisões do dizer.

O analista intervém, considerando o que as dentistas demandam dele e o que, desse lugar atribuído e subvertido, consegue escutar e manejar no discurso em análise. Os movimentos que acompanhamos no decorrer dos encontros passam pelo manejo analítico e político das relações na transferência institucional, no cruzamento de posições discursivas.

No lugar das dentistas e de suas práticas, o objeto institucional delineado nos parece o tratamento odontológico. As dentistas demandam saber sobre a posição do analista/pesquisador e que ele costure a dispersão discursiva em que elas se encontram. Na transferência, delineiam-se posições nas relações entre as dentistas e delas, analisandas e participantes de uma pesquisa de doutorado, com o analista/pesquisador/seu estudo.

Se nos primeiros encontros, as dentistas demandavam do analista fortalecimento, neste momento, elas lidam com a fragilidade/força em seus posicionamentos. As profissionais mostram-se mais como sujeitos e com mais flexibilidade nas relações que constroem na Odontologia. Surgem mais lugares de enunciação com efeitos nos enunciados; relativizações emergem. O calar é 
delineado com força produtiva de resistência da dentista-aluna na instituição de ensino, não como consentir. Insubmissão ao adágio popular "quem cala consente"? Os limites, que nos parecem dimensão importante dos atendimentos odontológicos, são vistos em vários níveis. Romper condicionamento, colocar-se do lado do paciente, e não da profissão (como fora mencionado no encontro passado), mostram movimentos nas relações na Odontologia.

Os efeitos do trabalho analítico depreendem-se: término como re/abertura ou começo, reconhecimento de identidade de experiência, troca de vivências, não sossegar mais, não estar com medo ou desespero, alívio, suporte, desabafo, esperança, otimismo, possibilidade de melhorar, ruptura da rotina, ampliação da análise, entre outros. Imagens de abrir. Os encontros grupais mobilizaram o fechamento em si das dentistas.

Percebemos que houve, com a escuta analítica, uma maior implicação das dentistas, um movimento, não de forma linear, de uma posição queixante para uma analítica, reflexiva, com questionamentos. Surgiu uma mobilização na visibilidade nas relações com o outro, o que inclui o analista, com abertura de ângulos e reconhecimentos. Produziram-se mais lugares no pensamento com efeitos institucionais e singulares, no modo de as dentistas se colocarem e lidarem com suas demandas.

Intervalos, reticências, frases inacabadas, vocábulos quebrados e termos como "no fim" mostram o (não) término na ordem do discurso, por exemplo, na dificuldade de desligamento das dentistas dos encontros. O tempo verbal passado é bem presente neste dia, como marca de um momento em que as dentistas olham para o que transcorreu. A identificação do trabalho de análise com um espelho multifacetado, o tirar do silêncio e promover ouvir mostram efeitos da escuta analítica. A dimensão especular revela-se fundamental. Parece que as profissionais se sentiram vendo e sendo vistas e também com a força da Palavra.

O término é visto na dimensão espacial (“Acabou aqui."), mas não na analítica: as lembranças dos encontros podem continuar a mobilizar as relações e práticas na Odontologia. Isso sugere que a análise se produz como interminável. Na dispersão ou pluralidade de vozes, as dentistas "amarram" um novo encontro: uma "saída" para o vivido (para um restaurante), já que a porta ficou aberta?!

Destaquemos que algumas dentistas tinham demandas terapêuticas e, no dito, mostram efeitos terapêuticos da análise institucional do discurso. Do mesmo modo, 
o dizer evidencia mobilizações em posições discursivas, movimentos analíticos múltiplos, para além daqueles.

O lugar do paciente produz-se com mais fluidez. Nos movimentos do dizer, é reconhecido pelas dentistas que o resultado do trabalho depende dos dois lados da relação. Dar à clientela o que ela quer receber mostra uma maior visibilidade dos diferentes lugares nos contatos na Odontologia. A clientela é vista limitando e sendo limitada. Dimensões fundamentais dos encontros são reposicionadas e/ou ressignificadas. A atribuição de força circula mais nas relações e é vista em ligação com a fragilidade nos lugares discursivos. Diferentes expectativas são reconhecidas entre pacientes e dentistas.

O lugar do acompanhante não emerge tanto neste encontro, mas podemos inferir mobilizações neste pela maior flexibilidade nas relações entre as posições discursivas nos níveis de interlocução.

\section{Primeira cena: os sentidos do término}

Em círculo, com a participação de oito dentistas, o analista inaugura a cena discursiva, delineando o presente dia para finalização dos encontros grupais. "Né?", "não é?", assim como intervalos, reticências, "vou querer pontuar", "queria que a gente" surgem no posicionamento inicial do analista, mostrando a condicionalidade da construção da cena: depende das dentistas. Posicionamento similar ao do primeiro encontro?

O analista sinaliza que gradativamente quer fazer pontuações do que percebeu dos movimentos nos encontros. Ele se posiciona mais como "eu" (na singularidade). No manejo da transferência, discutir sobre o término, associado analiticamente à finalização dos encontros grupais e do atendimento odontológico, é a proposta:

([...] hoje é nosso último encontro. E é um encontro pra finalizar a trajetória de vocês aqui neste grupo [...] E eu percebi uma mobilização em relação a vários aspectos que eu vou querer pontuar aos... aos poucos pra vocês. Ah! Só que uma questão que ficou da última vez que a gente se encontrou foi: "como terminar? Quero ver como você vai terminar. Como terminar?" E essa questão, inclusive, apareceu na relação de vocês com os pacientes. Como em algumas situações é difícil finalizar o atendimento odontológico, não é? Então essa questão do término apareceu tanto em relação ao paciente odontológico por parte de vocês: a questão do tempo, é... a questão de uma pessoa pedir uma coisa pra fazer, né? E também apareceu em relação ao término 
daqui [...] Então eu queria que a gente começasse discutindo sobre... sobre esse aspecto que eu achei importante: o término [...])

A: Exemplos de falas mostram diversos sentidos para o término, como sentido espacial; não saber; conclusão de tudo que foi comentado; construção de vínculo/poder contar com as colegas; em antítese, começo; porta aberta/imagem do abrir; ruptura da solidão/isolamento; afirmação da identidade de experiência; movimento/não sossegar; efeitos no medo de dentistas/alívio; esperança e otimismo; algo a mais. O "eu" surge mais no dizer das profissionais. Há intervalos/reticências na estrutura discursiva; o inacabamento está na ordem da enunciação. "Né" e "não é?" parecem mostrar hesitação:

Carla: Finalizar assim que a gente tá aqui, né? (Isso) Eu acho que... não sei. Concluir. Chegar a uma conclusão de tudo que foi abordado.

Bianca: [...] Eu acho que criou vínculo entre a gente. Então concluiu nosso compromisso oficial, mas o nosso relacionamento, não. Muito pelo contrário, aprofundou mais. É até um começo.

Bianca: É uma porta aberta, né? Pra a gente chegar: "oi, fulana, você precisava ver." Não vai chegar sozinha em um lugar desconhecido como nós [...]

Dulce: Eu acho que a gente finalizar o que foi abordado aqui em todos os setores da Odontologia aqui, eu acho que é... é praticamente impossível, não é? (Hum hum) Porque os assuntos ficaram, só que a gente... O interessante foi que cada um percebeu que a gente tá... o que a gente sente, ela sente, ela sente, ela às vezes já sentiu. Já passou pela experiência [...] Agora finalizar assuntos diversos, eu acho que fica aberto e a gente vai procurar melhorar todos eles. Porque já sabem que acontece no dia a dia. Então a gente não... sossega mais. Eu já não... não tou com medo nem desespero. Assim, hoje em dia...

Dulce: [...] Fica aberto. Acho que a gente vai tendo mais... é... esperanca, maior otimismo de que cada um pode melhorar a Odontologia.

Dulce: [...] É uma porta aberta. Eu posso chegar... ligar pra Mônica. Eu posso contar, porque a gente tem um contato a mais. (Hum) Já tem uma experiência a mais. E sabe que pode contar com qualquer um de nós aqui.

Luara: Cumpriu um papel importante. A gente chegou aqui, a gente viu que as outras pessoas também passavam pelas mesmas coisas que a gente, aí já vai como se fosse aliviando. "Ah, não é só eu que passo por isso!"

A: $O$ analista indica o movimento das dentistas de entrarem em análise. Ele se posiciona como "eu" e com o verbo no passado. Acompanhemos o exemplo:

( $E$, e eu percebi que vocês ficaram, às vezes, até dizendo: "eu pensei em casa" ou "Eu fiquei refletindo sobre isso". "Eu achei que eu tava numa postura mais de queixa e depois que a gente tem que transformar." [...] Eu senti um movimento no grupo, não é?)

A: Mostraremos a posição de Bianca, que é bem elucidativa do lugar de questionamento em que as dentistas passaram a ocupar. A atribuição de terminar ao 
analista, suposição transferencial de saber, surge no passado. Mobilização de seu posicionamento? "Eu" singular emerge:

Bianca: Porque, assim, pra mim parece ter muitas interrogacões, né? Muitas interrogações. Aí por isso eu achei: "como é que você vai finalizar?" Porque a gente levantou muitas questões.

A: O analista reendereça o dizer às dentistas ("como nós vamos terminar?"), no manejo da transferência em que interpreta término como lidar com limite/falta e faz referência à dificuldade das odontólogas de lidarem com o limite nos atendimentos odontológicos. O analista coloca-se no grupo ("nós"); posição esta que oscila, no decorrer dos encontros numa postura sua de aproximação/distanciamento em relação às dentistas para a construção de vínculo, mas também para a operacionalidade analítica; às vezes involuntariamente. Seu discurso tem marcas de interrupção/inacabamento (reticências e vocábulos quebrados):

([...] "como nós vamos terminar?" [...] Então, o que é terminar? Terminar é li... lidar com limite, não é? [...] Como às vezes é difícil lidar com limite: ah... em relação ao tempo, em relação à cobrança, em relação ao próprio acompanhante. É... vocês trouxeram que às vezes o próprio corpo, se esquece o limite [...] terminar é lidar com limites, não é? É li... lidar também com algum tipo de falta [...])

A: $\mathrm{Na}$ sequência, um exemplo bem elucidativo da transferência mostra o deslizamento associativo do termo falta. Nele, o grupo é identificado ao sexo feminino. Em nossa compreensão, a ausência marcada de um docente sinaliza a presença de uma posição de analista ao pesquisador que chamavam, várias vezes, de professor. A Educação é reeditada nas cenas em grupo com dentistas? Ocorre flexibilização na visibilidade do lugar dos dentistas e de suas práticas. Produz-se o começo de uma nova visibilidade. O termo fim surge no discurso, bem como identificamos marcas do inacabamento na linguagem como ação por meio de reticências e vocábulos incompletos. O "eu" singular emerge mais que antes.

No segundo exemplo, reconhecemos o deslizamento do vocábulo limite numa posição de sujeito à dentista. Não parar nunca destaca uma imagem de movimento no tempo:

Célia: [...] Aí eu tava pensando. Eu digo: é interessante. Esse grupo da gente é um grupo de mulheres, mas cada uma, cada um com seu tempo de serviço, cada uma assim na sua especialidade. Tem gente aqui tá... é especialistas, né? Têm especialistas; outros, não. Tem eu que trabalho só em posto. Cada um com sua vida, com sua re... sua maneira de pensar em relação ao seu trabalho. Aqui eu acho que só faltou um docente. Um professor [...] eu acho que a gente foi comecando a... a ver, né, que a dificuldade que todo... cada uma tem é a que a gente tem, né? Cada uma tem a sua dificuldade que, no fim, todo mundo tem em todas as profissões [...] 
Célia: [...] Mas... é isso que a gente encontra: os obstáculos, as dificuldades, as pessoas que não tão "nem aí" pra profissão da gente. Isso tudo. E a gente tem que... saber, vai, ir, ir correndo e limitando. E, e... ver o que pode fazer. Agora eu acho que não deve se parar nunca [...]

A: Alguns outros exemplos ilustrativos das contribuições do grupo mostram efeitos terapêuticos de relaxar, enxergar, desaprisionar, ruptura de rotina, desabafar e encontrar acalento:

Célia: [...] no fim eu acho que é como elas disseram: a gente terminou relaxando e vendo que cada uma no seu cantinho, no seu espaço, passa pelas, pelas dificuldades, pelos problemas.

Mônica: [...] Têm vezes que a pessoa não entende [...] Você fala pra pessoa, assim não en... não sabe o que você tá vivendo. Não sabe aquilo que você tá... tá passando [...] Aqui, não. A gente sabe que todo mundo tá se vendo.

Denise: É, você tá o dia todo presa ali: consultório, consultório; chega em casa: descansa, dorme, no outro dia, a mesma coisa. Final de semana, estudar. Curso de especialização. Aí só a rotina. Então é uma coisa ... foi uma coisa bem diferente, que tava precisando.

Manuela: [...] Parece que a gente tinha defesas, pelos problemas que a gente passava na semana, que a quinta-feira a gente poderia desabafar. A quinta-feira, a gente poderia encontrar o acalento que a gente precisava na, nas outras pessoas que não souberam passar pra gente, e aqui a gente tinha.

A: $O$ analista movimenta sua hipótese interpretativa do quinto encontro. Ele associa, neste dia, falar mais das dentistas de si e de suas práticas do que dos pacientes e acompanhantes a desabafar no tocante às condições e relações de trabalho.

A constatação que não mudou é que as odontólogas falaram mais delas do que dos pacientes e acompanhantes. O porquê interpretativo de tal evidência é que foi revisto nas interlocuções em grupo, desde o quinto encontro (e reconhecemos que os sentidos podem ser múltiplos). O sofrimento maior das profissionais foi configurado produzindo-se, sobretudo, exterior às relações com a clientela. $O$ contexto parece falar alto! Não sem que ocorram problemas nos contatos com pacientes e acompanhantes. "Eu" singular emerge ao analista:

([...] Esse ponto que vocês trouxeram que é o desabafo, eu percebi como se vocês estivessem abafadas por tudo que significa ser dentista, não pela relação com 0 paciente que vocês disseram muitas vezes que gostam, mas por tudo: pelas questões mercadológicas, pelas questões políticas, lidar com o gestor, cada um com sua particularidade. E aí vocês desabafavam [...] na minha percepção, vocês falaram mais do dentista do que da clientela, do acompanhante, como se fosse tanta coisa que vocês tivessem que lidar o tempo inteiro, o tempo inteiro, que aí aqui era um espaço pra vocês [...]) 
A: Uma frase ilustrativa, que surge a partir da interpretação analítica, ressalta a importância da compreensão do interlocutor e associa a escuta da dentista, não apenas sua fala, a alívio:

Luara: Acho que mais importante do que está desabafando é assim: você ter a oportunidade de desabafar pra um monte de gente que entende o que você está falando [...] Então, eu tava assim abafada e... com vários problemas. Até nem falei tanto, mas só de ouvir aquela pessoa falando e vê que ela passou mais ou menos o que eu passei, já... fui aliviando.

A: O analista aponta para possíveis mobilizações, no decorrer dos encontros, no que diz respeito aos lugares dos profissionais e de suas práticas, dos pacientes e dos acompanhantes. Ele entende lidar com limites/concluir como dimensões centrais nos encontros, trabalhadas no manejo transferencial:

([...] Então, na minha percepção, vocês foram mobilizando, movimentando os posicionamentos de vocês, como vocês se colocavam na relação: consigo mesmos, com os colegas, com a profissão; com o cliente; com o acompanhante. Eu percebi uma mobilização. Vocês foram abrindo cada vez mais ângulos. Falaram das diferenças dos serviços. Falaram da formação. Da busca por aperfeiçoamento, especialidade [...] Um dos pontos que eu percebi, que eu cheguei a levantar é esse: do limite e do terminar [...])

A: Nas interlocuções, surgem diversos exemplos nas mobilizações de sentidos para os termos limite e terminar. Agentes institucionais, assim como clientela são vistas com limites. Odontologia como tratar (seu objeto institucional?) e dimensões econômicas ressurgem no discurso. As enunciações desdobram-se com maior flexibilidade, produzindo múltiplos sentidos. Chama-nos a atenção que a correlação de forças/fragilidades ganha mais movimento. Surge uma ampliação da análise e o não assujeitamento da dentista ao plano. Há reconhecimento da diferenciação nos lugares da relação entre profissional e paciente:

Célia: Eu lá no serviço, eu sempre lido com limites... Eu tenho... Porque a gente nunca tem tudo que quer. Nunca tem na... assim, condição de trabalho decente. (Hum hum) Então, a gente termina se conformando, se acomodando. (Hum hum) É uma coisa que eu, eu não queria nunca me acomodar, mas assim: independente de qualquer coisa, eu já termino. $E$ diferente de eu ter meu consultório e estar vivendo o que quiser, não é? (Hum hum) [...] tem o limite que o pa... que o paciente impõe à gente. Na minha área, eu tenho muito limite de saber que o paciente quer terminar, mas não tem condições financeiras. E a coisa, o limite de eu tentar buscar ou ser rápida no tratamento, né, pra ver se eu consigo terminar e ficar frustrada muitas vezes por não conseguir, porque a gente tem que correr contra o tempo.

Denise: Tem paciente que começa a colocar aparelho e não tem condições de fazer 0 tratamento.

Célia: Têm uma série de pacientes lá que inclusive depois que eu conheci as meninas, tou encaminhando. Converso. Ah... é, é um valor pequeno. Pequeno pra gente, né? Mas pra eles! Aí eu... Aí eles ficam frustrados e eu fico frustrada. Porque eu vejo as 
crianças com a boquinha com... precisando de aparelho, tudo. E tá ali! Tudo indica. Eu não posso fazer mais nada. O que eu posso fazer, eu faço [...]

Dulce: No aspecto da Endodontia, eu vejo mais, pelo que eu já atendi, é cultural e financeiro, né? [...] Você sabe que tem uma lesão grande ali. Sabe que ali todas as condições dele não vai diminuir aquilo. Como é que você vai colocar esse tipo de... de afirmativa pra ele: que não, vai se...? Têm muitos pacientes que não entendem. "Tá pronto? Tá pronto? Acabou? Acabou." E isso não terminou pra gente [...]

Dulce: [...] Aí a gente já amplia. $\underline{\text { Hoje eu já estou ampliando essa minha análise. }}$

Denise: Às vezes, eu faço uma placa assim e, às vezes, ficam doentes. Aí... fulano, por exemplo, eu tou trabalhando com plano e que tem a população por mês. Você não pode ultrapassar peso $x$. Cada procedimento tem um peso. $O$ paciente chega precisando fazer. Eu trato. Eu faço. Sem res... Eu, eu, eu tou ali com... Tá no meu carro. Eu trouxe pa olhar. Porque várias coisas que eu fiz. Tem paciente que eu já adiantei até dezembro. Porque é coisa de urgência. Se eu não fizer, vai perder os dentes.

A: No manejo da transferência, o analista faz espelhamento investigativo. O que fala tem implicações no dizer confirmatório da dentista. Finalizar/concluir, que se discute no grupo, é interpretado analiticamente como questão do cotidiano das dentistas e atribuído, sob a forma de questionamento, à cobrança. $O$ vocábulo término volta a estar na ordem discursiva:

(Então vocês lidam com limite e falta o tempo inteiro?)

Célia: Inteiro.

(Não é? Então, essa questão é... do acabar, do finalizar, concluir tratamentos, parece que é uma questão de vocês do dia a dia e uma cobrança, né, que termina sendo do profissional de ter que dar conta de tudo, de ter que concluir tudo. Será que isso não acontece?)

A: Alguns dos exemplos ilustrativos que emergem entre as dentistas nas interlocuções mostram relativizações/reposicionamentos quanto ao término. Podemos entender tais mobilizações como efeitos de subjetivação nas condições de produção do discurso? Os enunciados são múltiplos na ordem de um maior movimento nas enunciações? Condicionamentos são problematizados.

É delineado poder contestar na instituição de ensino. Calar surge como resistência singular e producente, não como quem consente. Subversão do adágio popular? Há visibilidade da força no lugar de aluna por ter casos e experiência. Colocar-se do lado do cliente destaca-se; não da profissão, como tinha surgido no quinto encontro. As dentistas estão, ao fim, em uma posição mais implicada de sujeitos, questionando o instituído em suas práticas:

Bianca: [...] Mas assim é... nós fomos treinados e a gente vê em toda fichinha, tal, a ter início e fim. Tem a data do início do tratamento e o fim do tratamento. (Hã hã) Então tem o início e o término. 
Célia: Já condicionou.

Bianca: Não é? Condicionou. Então tudo a gente fica: é nisso e nisso. Vê o fim do que a gente se predispôs no início, a fazer. $E$ aí eu vi que não é assim, não é? A gente planeja, a gente cria metas, mas pode alterar datas da, da, da conclusão, a data da realização dos nossos... dos nossos objetivos. Então, a gente tem que ser maleável pra tratar com... as coisas que ocorrerem. De repente, é uma enfermidade. De repente, é uma viagem, uma mudança, falta do dinheiro ou uma perda de emprego. Tantas coisas que podem acontecer, e a gente é condicionado a... Eu acho que talvez seja um condicionamento, né? A... a não pensar nessas coisas. A começar, tem que terminar. Começar, tem que terminar. Então, hoje é essa questão de... ah, o paciente, eu fiz um tratamento com lesão e ficar acompanhando o tra... o paciente, tal, não é?

Bianca: [...] A gente tá num curso [...] e aí eu digo a você que eu tenho muitos casos. Eu tenho os casos. Não é o caso de $A$, de $B$ ou $C$, não. São os meus casos. Então, se você me disser que dar uma medicação não funciona, eu posso contestar com você [...] Eu fico calada, porque eu tenho experiência que não é assim como você tá dizendo, entendeu? [...]

Bianca: E assim, né? E esclarecer o paciente. A gente não tem que se estressar. Eu acho que é por isso que eu, né [...] sou apaixonada, porque eu procuro me colocar do lado do paciente e tentar mostrar pra ele que também não é... não é Matemática [...]

A: O analista mostra dimensões que vê de mobilização no grupo. Postura mais ativa e ruptura da solidão são enfatizados. Ele assinala que as dentistas saem da queixa. Pensamos, na análise da análise em ato, que elas estão em transição e movimentando-se nos posicionamentos:

([...] Então, eu vi esse movimento também em vocês: tanto de sair da, da queixa, no sentido de "ah, ficar me queixando da área, ir pra uma postura mais ativa de ver o que é que eu posso fazer pela área", como eu também percebi esse movimento: "como é difícil, quando eu me isolo. E quando eu me relaciono; quando eu formo grupos, é diferente.")

A: $\mathrm{Na}$ desconstrução do isolamento na Odontologia, exemplos bem elucidativos surgem de mobilização nos reconhecimentos e desconhecimentos das dentistas com a escuta analítica. Saíram do enclausuramento? A porta se abriu? Um espelho multifacetado representa o grupo: efeitos da escuta analítica na rebeldia da língua, constructos simbólicos no campo da visibilidade, do imaginário? Parece surgir agora uma possibilidade de as profissionais movimentarem o olhar com implicações na resolução de problemas.

A análise é configurada como interminável. O término restringe-se à dimensão espacial: "acabou aqui." Outras posições discursivas, lugares de enunciação, produziram-se e podem ser produzidos, de acordo com os reconhecimentos à escuta. O começo de uma nova posição mais móvel às dentistas é desenhada:

Bianca: E a Odontologia é uma profissão muito assim, né? Muito isolada, né? E o que eu achei do grupo também foi isso. Foi, colocou a gente diante de um espelho. Bem multifacetado, né? (Hum hum) Então, eu tou com essa visão: "tá, ela tá, ela tá... linda." 
Eu olho. Aí tou com esse problema, olho pra cá: "ela... resolvido." Aí, sabe? E a Odontologia, a gente ficava sempre muito ilhado, muito isolado, cada um no seu consultório, no seu trabalho. Até a gente trabalha... é... dentista, paciente e auxiliar. Sabe na mesma sala um... Sem condições, porque não têm condições. Mas tá ilhado também ali. Então, você fica realmente só. Quando chega aqui, foi um... um espelho multifacetado e, né, bem coloridos, cheio de nuances belíssimas, né? E realmente eu acho que só fez enriquecer. Né? Enriquecer.

E, e quanto a esta questão de término, não tem término, né? A hora que você acaba... "Ichi, acabou! Agora não tenho chance." Vou ter que olhar pra cá. "Ah, tem uma solução." (Ri) Acabou aqui. Entendeu? Então a gente se lembra, né? Das nossas experiências e num... nunca tem término. É por isso que eu digo: isso não é término, é um começo.

A: Os dois lados da relação, agentes institucionais e clientela, são vistos com maior abrangência, o que tem implicações nas reconfigurações de força, na micropolítica das interações:

Mônica: [...] uma série de coisas que fica difícil a gente sempre botar no tratamento.

Bianca: A gente sempre botar pra... Na gente. Na gente. É.

A: Outras frases que se produzem no dizer mostram movimentos nos lugares discursivos, nos reconhecimentos/desconhecimentos. Dulce, por exemplo, parece romper sua visão a respeito dos colegas de profissão, delineada no início dos encontros na formulação de sua demanda para com o grupo. Bianca relativiza o lugar do profissional quanto a acertar e agir. Há espaço para o não saber, uma enunciação que flexibiliza a produção de verdades. Seria esta uma posição confirmatória de "insight", mudança de postura conquistada? Com Manuela, os professores surgem ensinando mais do que as técnicas odontológicas. Há, então, os apoios nos discursos dos mestres, como responsáveis pela confiança na possibilidade, na potência de cada um para clinicar? Ocorrem também movimentos de diferenciação dentista/paciente, sinalizando os lados da relação. Denise salienta ainda as diferenças individuais. A diferenciação no lugar da clientela também é um indicador de movimento:

Dulce: $E$ o respeito que a gente adquiriu mais ainda com o colega.

Bianca: Isso que eu tinha falado pra ela. Isso até no nosso dia a dia, né? A gente tava conversando. Eu digo assim: às vezes, tá fazendo uma restauração, uma coisa boba e não dá certo. Não dá certo! Então, o que é que a gente tem que fazer? Parar. [...] Rapidinho. Sabe? Ir pra casa, tomar um banhinho, um jantarzinho, sabe? E já deixo o paciente agendado. "Olhe, seu... seu dentinho tá em observação. Na próxima consulta, a gente vai..." Chega no outro dia, é mil maravilhas. Não sei se era o estresse, o cansaço do dia, o paciente tava nervoso, falta de confiança. Muitas coisas que acontecem naquele instante; seria uma coisa boba, não dá certo. Não dá certo! É impressionante como acontece de vez em quando isso [...]

Bianca: Ninguém é dono da verdade. Ninguém é dono da verdade. 
Manuela: A gente tem... ex-professores assim, bastante marcantes: $X$ (Hum hum). $X$ me deu exemplo assim [...] "em que condições esse profissional está pra aprovação ou não? Depois que eu souber em que condições esse profissional estava, eu deixo o meu comentário a respeito... do que ele fez e o que é que ele deixou de fazer." Né? Que é uma coisa assim, muito marcante. Eu num... preciso saber em que condições ele estava. E tem outro, outro professor, não é tão marcante, mas... é importante também, que foi N. Ele disse assim: "a gente tem que dar ao paciente aquilo que ele quer receber." (Hum hum) Não adianta a gente querer dar mais, se o paciente não quer receber.

Denise: Eu sempre disse pros meus pacientes, quando fiz canal, é igual à comida uma coisa. Eu sempre faço essa comparação. Tá num grupo de amigos, todos comem a mesma comida, um passa mal e os outros não passam.

\section{Segunda cena: interlocuções entre pesquisador e participantes da pesquisa}

A: Na segunda cena depreendida por nós, são posicionados o pesquisador e as participantes da pesquisa, não 0 analista e as analisandas. Bianca indaga 0 pesquisador da escolha da Odontologia em seu estudo. Este ratifica em sua resposta o posicionamento das odontólogas de um lugar privilegiado à Medicina em relação à Odontologia e verbaliza que não buscou resposta final e fechada em seu estudo. Bianca mostra compreensão, conforme recorte discursivo:

(Então é... Vejam o seguinte: eu achei que foi um grupo rico, muito rico em relação à minha perspectiva, né? Agora falando de pesquisa, como eu coloquei pra vocês, eu queria justamente ver o que acontecia quando dentistas se encontram.)

Bianca: Por isso que eu te perguntei: por que a Odontologia? (Risadas)

(Por que a Odontologia?)

Bianca: Só por que sua esposa é odontóloga?

(Risadas)

(Não. Eu acho a Odontologia uma área muito bonita, muito interessante [...] E os trabalhos é, é, se voltam muito pra a área médica. Eu queria dentro do campo da saúde é... trabalhar com uma outra área que não fosse a Medicina, não é? E... e eu achei é... O meu objetivo era ver o que acontecia, quando um grupo de profissionais se encontravam, tá? Então, não foi uma proposta de dar uma resposta final e fechada.)

Bianca: Uma solução (Risadas).

A: O pesquisador retoma e configura sentidos do trabalho realizado para ele e aponta movimento entre as dentistas. Ele se refere a uma análise em ato que fez 
junto com as odontólogas e legitima o lugar dos questionamentos que "ficam"; também reconhece os olhares de despedida de algumas participantes. A visibilidade mostra-se marcando a construção de seu lugar.

O agradecimento do pesquisador sinaliza que se produziu análise no equilibrismo das demandas/expectativas de quem estuda e das participantes do estudo. Uma análise, portanto, que se configura a partir de uma oferta de um "discurso do doutor" e da produção possível, com repetições e rupturas de campo, de lugares ao analista e analisandas, encontros e desencontros em cenas e posições do pesquisador e das integrantes da pesquisa, da Análise Institucional do Discurso e da Odontologia:

([...] foi um, um grupo pra vocês refletirem, pra vocês trocarem experiências e o meu papel era acompanhar algumas coisas. Uma das coisas era ver o que se movimentava na maneira de vocês enxergarem o paciente e o acompanhante. Eu achei que houve muito movimento. Vocês foram abrindo ângulos [...])

Grupo: Hum hum.

([...] Então é... essa foi uma análise em ato que eu fiz junto com vocês. As perguntas ficam aí. E eu sei que é um momento, percebi pelos olhares de algumas pessoas, que traz emoção, é uma despedida também da gente aqui [...] E também me vi enquanto profissional junto com vocês. Então eu também me questionei como profissional junto com vocês. Então pra mim foi riquíssimo, tanto acompanhar o que é ser dentista e as configurações e reconfigurações do que o dentista pode ser junto com o paciente e 0 acompanhante. E também foi muito bom pra mim, porque me fez também olhar para mim enquanto profissional, o que é que o psicólogo também passa, não é? Eu queria agradecer muito a vocês, a participação de vocês [...])

A: Um comentário elucidativo surge que apresentaremos em recorte. Mostra, na transferência, Célia identificada ao lugar do pesquisador, ofertando-lhe mais tempo, e a adesão das dentistas à proposta do trabalho em grupo. Se o pesquisador precisou das dentistas para seu estudo, as demandas destas tiveram escuta analítica a partir da qual as odontólogas (re)construíram sentidos para suas experiências:

Célia: Eu achei maravilhoso! [...] E é assim: eu como tava vindo naquele dia. Já trabalhei muito em pesquisa, tudo. Achei uma coisa muito... Até pra fazer também esse fechamento, esse negócio, tudo. "Eita, vai dar um nó na cabeça de R". Na minha cabeça, fica um nó, quando assim, faz, né, o dia a dia. E eu vou lembrar dos nossos, da, da, do nosso grupo. Mas eu acredito que todas aqui... Deni tá aqui: "Ai, meu Deus, hoje é o último dia?" Eu digo: "É, o último dia!" "Tou com pena, não sei o quê." Mas é isso que assim... Acredito que o que eu vou falar, todo mundo vai apoiar. A não ser... Não sei minha amiguinha aqui que vai casar esse mês... (Risadas) Mas se você precisar da gente, em algum momento, fazer... tiver na ta... assim enriquecer mais a discussão, todas aqui estão disponíveis e... Pra gente também foi maravilhoso! [...] 
A: $O$ analista indaga se elas gostariam de falar algo a mais. Surgem comentários sobre a colega, por exemplo:

(Alguém gostaria de colocar mais alguma coisa?... Então, a gente...)

Bianca: É assim. Eu, eu particularmente, né? ...Manuela é muito madura, não é? Puxa vida!

Dulce: Ela é assim. Quando ela fala, um negócio.

Bianca: Puxa vida!

Célia: É.

A: Ocorre um (des)enlace final hesitante e afetivo. Uma tentativa é o que se constrói/reedita na imagem de conclusão? O pesquisador responde à (proposta de) "saída" (para um restaurante) das dentistas com um sim; não estava mais em uma posição de analista que interpreta e assinala movimentos em grupo. Um lugar/não lugar emerge, em um tom de brincadeira, para a secretária do pesquisador, que, além de sua esposa, é odontológa. Posições transferenciais importantes mostram-se para ela (M), dentro e fora, construídas pelas condições de produção do estudo (Ela ficava externamente ao círculo nas reuniões e em silêncio, fazendo registros que facilitassem posteriormente as transcrições das falas), e para ele (R), o pesquisador, o que apresentaremos nos recortes discursivos:

Bianca: E assim: eu não tenho telefone de ninguém, email de ninguém, não prometo ligar pra ninguém e tal. É... nem passar email logo. Mas eu gostaria de email e telefone de todas, né? Eu queria que a gente tivesse todos guardadinhos naquele lugar escondidinho do lado esquerdo que ninguém mexe. Eu queria isso de você, tá?

Manuela: A gente poderia, então, finalizar tentando marcar alguma coisa pra gente se encontrar.

Denise: É, a gente poderia marcar.

Manuela: Nessa data, a gente trocar email [...]

Denise: $\underline{\text { Com R e M }}$, né? Pra gente... sair.

Manuela: Sem a M. (Risadas)

A: Adiante na interlocução, emerge:

(De hoje a quinze, que tal?)

Grupo: $\underline{O K}$

Denise: De hoje a quinze é o Congresso de Salvador.

Grupo: Não.

(Então Cantina I?)

A: Após um longo período com interlocuções, nas marcações espaciais/temporais, há a decisão da "saída" e as despedidas. À porta, surgem os 
comentários que mostram, na transferência ao par pesquisador e secretária, a reconfiguração de forças:

Bianca: Que bom! Um grupo bom. Ai que bom!

Célia: $R$, só você pra ter chegado àquele curso da [instituição de ensino] tão acanhadinho. Quem quer fazer sua pesquisa? [...] Adorei. Adorei você. Você e M são assim: duas pessoas iluminadas.

A: Após adiarmos esse encontro por telefone, o mesmo ocorreu em um restaurante da orla de Aracaju com a presença de R, M, Célia, Bianca e Manuela. Não houve troca de emails, nem se falou das reuniões grupais transcorridas, não foi combinada outra "saída". Ocorreu um momento suave de contato, vínculo e qualidade de vida. Produziu-se experienciar a relação.

Hoje, o lugar do pesquisador A (a maiúsculo), que se distanciou da análise em ato para fazer as análises da análise, está em intenso movimento analítico. Com a singularidade dessa experiência de doutorado, têm surgido reflexões diversas sobre a política das análises e dos movimentos possíveis na formação na Odontologia, e também na Psicologia, Psicanálise e pesquisa. 


\section{SOBRE O ATO DA ANÁLISE INSTITUCIONAL DO DISCURSO EM GRUPO COM DENTISTAS}

Quiçá este trabalho seja um disparador, entre outros, na construção de aproximações entre Psicologia, Psicanálise e Odontologia! Também um entre os vários meios de refletirmos sobre a pesquisa-intervenção, além de nos desafiarmos aos (des)encontros no discurso.

\footnotetext{
Winston Churchill - escritor - disse que escrever [...] é uma aventura. Principia um brinquedo e um gosto. Vira uma amante, depois um tutor, depois um tirano. Na fase final já conformado em ser seu escravo, você o mata e arremessa o corpo ao público (CORRÊA, 2008, p. 11).
}

Há que enunciar a particularidade dessa última cena discursiva: o pesquisador, em profunda relação com seu estudo, à guisa de conclusão de seu trabalho, o que configura posicionamentos e interlocuções com alguns dos autores que foram seus companheiros de viagem. E assim se faz Ciência... E assim se faz História...

Neste momento, sustentaremos nossa tese, pelos efeitos produzidos por nosso trabalho, de que a Análise Institucional do Discurso, estratégia de pensamento em criação por Guirado (1986/2004, 1987/2004, 1995/2006, 2000, 2007, 2009), bem conhecida no plano das pesquisas acadêmicas, com entrevistas, pode ser um referencial significativo ao trabalho em grupo, sendo uma possibilidade de intervenção distinta dos aportes clássicos da Psicologia e da Psicanálise por articular esses com conhecimentos provenientes de outras fontes do saber, como a Análise do Discurso Francesa, a Sociologia e a Filosofia, definindo seu objeto como as instituições ou relações institucionais discursivas.

Com nosso estudo, pensamos também que, em uma linha similar à de autores como Nogueira-Martins (2002), Pimentel (2005), Macedo, Nogueira-Martins e Nogueira-Martins (2008), acenamos para novas propostas no campo da saúde. A perspectiva desse trabalho faz rodopiar o paradigma biomédico. Ressalta, por outro lado, o sujeito no e do discurso e uma intervenção analítica psicoinstitucional na Odontologia, distinta de modelos clínicos psicológicos e psicanalíticos tradicionais. Desse modo, inspira possibilidades para os campos da Medicina, Enfermagem, Fisioterapia e Educação, entre outros.

Como comum à Psicanálise, em nosso trabalho, não nos colocamos em uma postura de querer "melhorar" a Odontologia, numa pré-definição valorativa do lugar 
de chegada das participantes da pesquisa e por meio de uma busca de troca do discurso encontrado na Ciência Dentária por um contradiscurso nosso, previamente pronto.

Foi preciso que navegássemos, na medida do possível, livres de concepções engolfadoras, em análise institucional do discurso das cenas/posições em grupo com dentistas e de seus movimentos/desdobramentos com nossas intervenções. Obviamente, nem por isso fomos neutros, já que tínhamos expectativas, pois este trabalho se constituiu como nosso estudo de doutorado e, como tal, não estava fora das condições de produção normatizantes da seara acadêmica. Aliás, pensamos quanto uma visão persistente de suposta neutralidade absoluta nas intervenções em Psicologia e Psicanálise, de um modo geral, além de alienada, bloqueia o avanço do conhecimento científico.

Mas quais foram os efeitos que se depreenderam com nossa análise em ato? $\mathrm{O}$ que aconteceu nos posicionamentos discursivos das dentistas e nas enunciações das relações entre agentes institucionais e clientela, da tríade dentistas-pacientesacompanhantes, na Odontologia?

As dentistas passaram a abrir perspectivas de análise com a escuta analíticoinstitucional: emergiram diferenças com a idade dos pacientes, o local de trabalho, a experiência profissional, entre outros aspectos. Em um mesmo encontro e no desenvolvimento das reuniões, houve mobilizações no pensar.

Faremos alguns assinalamentos do manejo dos encontros grupais, o que ressalta nosso lugar analítico na pesquisa realizada. Inicialmente, salientemos que a Análise Institucional do Discurso não se assenta no mimetismo do lugar (ou suposto "não lugar"?!) convencional do psicanalista.

Tivemos, sim, uma posição, ou várias, no discurso, e assim fizemos uma análise das relações institucionais em grupo. Recursos habituais à Psicanálise, mas também outros comuns em uma interlocução: perguntas, confrontações, interpretações, espelhamentos, sínteses, demonstrações, contraposições de dimensões discursivas, direcionamento de temáticas, verbalização intencional de vocábulos, entre outros exemplos, foram adotados.

Estávamos ligados aos lugares de enunciação, não apenas ao dito ou aos conteúdos. Entendíamos o inconsciente na perspectiva da divisão no discurso, da pluralidade de vozes em um dizer. O manejo da transferência passou pelo reconhecimento dela como expectativa/rearranjo institucional de lugares no discurso, 
não fora dele, como os de professor, pesquisador e psicólogo/psicoterapeuta dirigidos ao analista pelas odontólogas. Por isso, estivemos com uma atenção que flutuava para as cenas discursivas e as posições instituídas no dizer às dentistas e suas práticas, aos pacientes e acompanhantes, bem como seguíamos os efeitos de mobilização desses lugares, de sua cenografia com as intervenções que realizávamos. Desamarrávamos a cadeia discursiva, e assim eram produzidas as singularidades possíveis nos efeitos de subjetivação, com a organização de sentidos, das dentistas nas teias institucionais do discurso.

Desde o início dos encontros, por nós foi enfatizada uma postura próxima, o mínimo que nos foi possível verticalizada, para facilitarmos a construção do vínculo com as dentistas; por isso, inclusive, as reuniões tiveram uma disposição espacial em círculo. As odontólogas, por outro lado, pareciam querer sair da solidão: do exercício profissional não compartilhado com colegas. A busca da relação dentistadentista mostrou-se como um dos fortes ingredientes de ligação das participantes com a pesquisa desenvolvida.

Outro ponto relevante de vinculação das dentistas à proposta nos pareceu ser a posição transferencial do analista de professor, pesquisador e psicólogo. O fato de quem o secretariou, fazendo alguns registros escritos das falas, ficar fora do círculo foi um resíduo de uma postura das pesquisas clássicas ao lugar do pesquisador: como se pudesse neutralizar os efeitos da participação de sua secretária. Sem falar que era sua esposa e dentista. Sua presença/ausência surgiu no dizer em grupo ao sexto encontro - ao se combinar "uma saída" (a um restaurante) consentida pelo pesquisador - com a ambivalência em que ela foi posicionada espacialmente nas reuniões grupais. Constatamos quanto a realidade está no discurso, não fora dele! Pensamos também que a questão de gênero pode ter sido importante na dinâmica transferencial: o analista era o único homem, o varão.

O reconhecimento de que nosso trabalho se produziria em "uma zona de tensão" entre a demanda do pesquisador, configurada como oferta às participantes do estudo, e a produção de demandas às dentistas, para se engajarem na proposta, foi força motriz para nosso manejo analítico. Essa leitura de demandas nos orientou em todo o trabalho, engendrando, sobretudo, os dois primeiros encontros na constituição das relações institucionais grupais. A transição do lugar do pesquisador demandante ao de analista de demanda foi, a nosso ver, fundamental nos movimentos analíticos. 
Entre outros aspectos, por estarmos atentos às demandas e transferências das dentistas, à suposição de saber que nos foi dirigida por elas, houve a produção de confiança em nosso trabalho, e as dentistas falaram com bastante espontaneidade nos encontros. Elas marcaram que faltou um docente de modo que inferimos a existência de um analista, que não ensinava, nem respondia às solicitações das odontólogas, mas fomentava reflexão e considerava o entrecruzamento de diferentes níveis de relações em análise: a tríade dentista-paciente-acompanhante; o vínculo das participantes da pesquisa entre si, com o analista/professor/pesquisador/psicólogo e vice-versa. Também o analista teve seu lugar marcado por várias influências: as reuniões de supervisão, o exame de qualificação e as instituições discursivas diversas que o constituíram.

A solicitação inicial do analista foi de que as odontólogas falassem de suas práticas, dos atendimentos, das relações com os pacientes e acompanhantes. A clientela, diversas vezes, foi vista em uma posição de atrapalhar a ação da instituição Odontologia, localizando-se como obstáculo ao lugar das profissionais, o que encontrou expressão emblemática em uma das falas de uma das participantes que se referiu à "língua rebelde" do paciente, provavelmente por se movimentar durante os procedimentos odontológicos. O desenho que se criava nos lugares de enunciação parecia ser de um antagonismo entre agentes institucionais e pacientes/acompanhantes, com implicações temporais ao atendimento na Odontologia.

Houve mobilizações nos reconhecimentos e desconhecimentos no discurso, por meio da escuta analítica, e reconfigurações de força nas relações na Odontologia, e também nos contatos entre dentistas e analista por meio da transferência. Foi o modo de estabelecer a interlocução com o outro, deslocável, que fundamentou este trabalho analítico como ruptura e desnaturalização do pensar.

Não falaríamos de relações objetais na constituição do inconsciente, mas de relações de enunciação e efeitos de subjetivação ao que chamaríamos de um paradigma institucional-discursivo de sujeito e análise. Trabalhávamos com as imagens, as metáforas, os indicadores da heterogeneidade no discurso, as posições enunciativas, sendo o relacionamento analista-dentistas cerne para o manejo da análise em ato.

No segundo dia, houve uma proposta de encaminhamento da discussão por uma dentista: uma demanda de fortalecimento do lugar profissional. As relações 
com pacientes e acompanhantes foram vistas por ela como efeitos deste lugar. Se a solicitação da odontóloga, reafirmada pelas colegas, foi de força, supomos a fragilidade na imagem de si e de suas práticas. As dentistas queriam ser valorizadas, inclusive no nível mercadológico. Essa é a posição de queixa que se movimenta, porque o analista facilita a discussão das odontólogas sobre seu fazer e relacionar-se.

Nos segundo e terceiro encontros, enredou-se uma discussão sobre o fortalecimento da posição profissional. As dentistas aproximaram-se dos discursos da Educação e da Política em suas interlocuções. Elas buscaram, de um modo geral, construir um lugar para "a classe".

Percebemos que as dentistas frequentemente falavam mais de si do que da clientela. No manejo do analista, houve a proposição de que elas verbalizassem sobre a rotina, a relação com os pacientes e acompanhantes, no quarto encontro. Nesse dia, surgiu mais a vulnerabilidade profissional. Houve também o destaque por uma profissional do escape das dentistas ao que o analista perguntava. Era como se elas quisessem falar de si, para queixar-se, e o analista interviesse a alçar dimensões da relação e a produzir a implicação das odontólogas em seu dizer. Surgiu ainda a indagação de como o analista iria concluir, bem como uma oferta de mais tempo a este pelas odontólogas. O vínculo das participantes com o trabalho analítico estava claro.

$O$ analista admitiu que as dentistas queriam verbalizar e pensou se concluir não era uma questão nodal dos atendimentos das profissionais, tal como a temporalidade. Dar mais tempo pareceu localizar as odontólogas, na posição de clientela, cooperando com o analista (profissional), e não almejando, apesar de suas demandas, antagonizar com a proposta do pesquisador. A hipótese formulada pelo analista em pensamento foi a de que algo da relação dentista-paciente era reeditado com alterações, por exemplo, no tempo (concedido), no contato das odontólogas com o analista. Não foi percebido, porém, por este, em tal momento, quanto a identificação com o lugar de pós-graduando pesquisador pode ter sido importante nesta transferência.

No quinto dia, houve continuidade da reflexão com o foco voltado, tal como no quarto encontro, para a relação com o paciente e o acompanhante. $\mathrm{O}$ analista assumiu uma postura com mais assinalamentos. Ele levantou uma hipótese, que não foi confirmada, a respeito do porquê de as dentistas falarem mais de si e suas 
práticas no grupo: por não haver espaço para elas nos atendimentos odontológicos. Para a constatação de uma predominância no discurso do lugar de profissionais e suas práticas em relação às posições dos pacientes e acompanhantes, surgiram outros motivos que mostraram o sofrimento das profissionais por causa do contexto, das condições e relações de trabalho.

No manejo da transferência, o analista pôs-se, de forma interventiva, no lugar de dentista, o que produziu um movimento empático de descentração. Com o desenvolvimento da análise, as odontólogas colocaram-se nas posições de pacientes, acompanhantes e psicólogas, quando houve mobilizações significantes nos lugares discursivos e nos sentidos produzidos desses. Percebemos que movimentos surgiram no imaginário, na visibilidade das relações, e na reconfiguração de forças nesse. Algumas dentistas verbalizaram que não gostavam de ser pacientes na esfera da Odontologia e viram outros ângulos da clientela: por exemplo, o ataque desta foi compreendido como uma defesa, ou seja, uma suposta força ocultando uma fragilidade. Como (e o que) concluir voltou a surgir no discurso, endereçado ao analista, que devolveu a pergunta às dentistas.

No sexto encontro, o analista pôs em cena o término das reuniões, fazendo uma interpretação transferencial que associou este à vivência de finalizar o atendimento odontológico. Termos como limite e falta foram posicionados no discurso, pois o analista percebeu a dificuldade de algumas profissionais de lidarem com tais dimensões na Odontologia. As dentistas também falaram da experiência de terem participado do grupo, ressaltando dimensões favoráveis.

Percebemos não apenas no dito, mas no dizer os movimentos nos reconhecimentos/desconhecimentos e na micropolítica (configuração de forças) das relações. Se inicialmente as odontólogas pediram força, elas lidaram, ao final, com uma posição questionadora, de maior implicação, com a falta. Surgiram também mais lugares de enunciação e relativizações com a escuta analítica.

Os sujeitos falavam e ouviam, emocionavam-se nos movimentos da linguagem à escuta construída. $O$ inconsciente não se esgotou, porque ele não se esvai. As relações grupais mostraram-se como um espelho multifacetado com ângulos mutantes. Efeitos do que foi especulado? De uma construção de pesquisa que, em vez de ativar o sentido da visão, que permeia a formação na Odontologia, reposicionou a boca não para ser vista, mas para emergir o sujeito da linguagem em sua rebelião discursiva imagética, o imaginário no e do discurso a ser ouvido? A 
análise configurou-se como interminável ao término, como um começo, uma esperança com ressonâncias sinalizadas, mas incalculáveis na historicidade das práticas discursivas.

Se o próprio corpo é muitas vezes esquecido por profissionais na Odontologia; se a indiferenciação ou fusão pode ocorrer em um trabalho dentro da cavidade oral que exige concentração, ou um pensamento superfocado; se a invisibilidade do sofrimento na clientela é uma defesa; se marcar o saber sobre o que dentistas fazem, mas não a respeito da relação com o contexto, carrega desconhecimentos de quem trabalha no cenário odontológico; se 0 paciente e o acompanhante obstaculizam as ações da instituição Odontologia e ao odontólogo o possível é tentar; se a cadeira, ora do dentista, ora do paciente, tem sido dispositivo de poder nos atendimentos... mesmo assim, é possível resistir, mas não no sentido freudiano de negatividade do recalcado; na dimensão producente da (des)construção de lugares sociais discursivos, o que depende dos passos de muitos.

Aqui temos o trilho analítico do "trabalho das formigas". As instituições não estão prontas; são criadas por mulheres e homens no agenciamento de suas intenções e atividades nas relações com a clientela e na (re)definição de seus objetos institucionais. A Odontologia não está acabada; nem também são práticas e pensamentos finalizados a Psicologia, a Psicanálise, as relações entre Psicologia/Psicanálise e Odontologia, a Análise Institucional do Discurso. Se o olhar marca a Odontologia atual, se a escuta criva o lugar de psicólogos e psicanalistas, há possibilidades para o inédito no nível interinstitucional.

Sobre a formação de dentistas, admitimos, com base em nosso estudo, que foi vista como insatisfatória para a construção de habilidades e competências na atualidade. O que é ser um odontólogo na contemporaneidade é a tônica que precisamos refletir. Quanto o aperfeiçoamento e a especialidade, a pós-graduação, surgem para suplantarem lacunas da graduação na produção do fazer? Como um mercado paralelo?

Por outro lado, pouco espaço parece constituído ao papel profissional na Odontologia de ultrapassar as fronteiras dos procedimentos e do tratamento no âmbito da formação, apesar de concepções outras como as da Saúde Coletiva que problematizam o lugar dos dentistas. O objeto institucional da Odontologia, configurado neste trabalho específico com odontólogas que, de um modo geral, 
lutam para sobreviver e realizar uma Odontologia de boa qualidade em diferentes locais foi, sobretudo, o fazer/tratar odontológico.

Não podemos deixar de contextualizar o percebido com discursos sobre a História da Odontologia. Wynbrandt (1998), por exemplo, referiu-se à obscuridade das origens do que se conhece hoje como Odontologia. Figlioli (2001), por sua vez, localizou o nascimento da Arte Dentária com as primeiras dores de dente. Podemos traduzir: o fazer prático parece fundante na Odontologia como cena originária, o que produz implicações a serem refletidas pelos epistemólogos e historiadores da área.

Na mesma linha de raciocínio, aproximamo-nos do comentário de Ring (1998) da emergência do dentista de vários praticantes e de Furtado (2007) que indicou a diversidade de profissionais que atuavam na Odontologia no Brasil. Conforme Figueiredo et al. (2007), entre outros autores, há um percurso do extracionismo às novas perspectivas na Odontologia.

Se, no grupo, as dentistas diferenciavam-se da prática extracionista/mutiladora almejada por alguns clientes no serviço público, por exemplo, expressão da força dos momentos mais antigos da Odontologia no imaginário coletivo, o atendimento odontológico surgiu, muitas vezes, identificado a tratamento, provavelmente, entre outros motivos, também pelas peculiaridades, em nosso estudo, das atividades profissionais das dentistas participantes e de sua clientela.

Walter, Ferelle e Issao (1996) ressaltaram a importância da educação para a saúde. Weyne e Harari (2006), por outro lado, sinalizaram que novos conhecimentos ainda não permearam os currículos da área. Pinto (2008), por sua vez, ao falar da resolução de problemáticas da saúde bucal, indicou a dimensão das variáveis extraodontológicas. Roncalli (2003) contribuiu para refletirmos sobre políticas sociais. Werneck e Ferreira (2008) comentaram que, no Brasil, há pouco investimento em políticas públicas, que promovam saúde e propiciem qualidade de vida, principalmente em segmentos menos favorecidos.

Desafios que precisam ser enfrentados na formação de dentistas, na instituição da Odontologia, assim como muitos outros. Afinal de contas, além das relações entre Sistema Único de Saúde (SUS), Programa Saúde da Família (PSF) e Sáude Bucal, das quais depreendemos ambiguidades, conforme interlocutores de nossos capítulos teóricos, a Odontologia pode, a nosso ver, construir outros movimentos contra a correnteza da lógica neoliberal. 
As dentistas desta pesquisa sofrem pelas condições e relações de trabalho no contexto de um mercado desafiante e competitivo, o que é importante ser refletido pelos representantes dos órgãos de classe e das instituições de ensino, bem como pelos docentes responsáveis pela formação de dentistas e pós-graduandos em Odontologia. Principalmente, quando pensamos que muitas participantes deste estudo são jovens e estão a construir seu papel profissional e lutar por seu pão de cada dia.

E como darem elas conta da relação com o gestor e os colegas de profissão em seu trabalho, se não discutirem sobre tais dimensões das práticas? Como lidarem com a imagem pública da Odontologia nem sempre favorável? De que modo não se assujeitarem a um contexto precário, quando as profissionais não têm um consultório próprio, conforme o modelo elitista de atendimento clínico? Como haver a proposição de mudanças na Odontologia, se os aspectos sócio-históricos da profissão e a perspectiva da saúde coletiva não forem devidamente problematizados e contemplados na formação? Parece que as odontólogas vão "enchendo-se" para depois se esvaziarem em um sopro, ou com vários suspiros, quando falam de si e de suas práticas, de seus corpos cansados, de seu cotidiano nada fácil.

Como dentistas lidarem com pacientes e acompanhantes que obstaculizam ou são inconvenientes? Como manejarem a cobrança de pagamento? A formação na Odontologia precisa contemplar uma construção de um lugar profissional que vai além do tecnicismo, pois, caso contrário, só resta à sensibilidade e à experiência profissional a possibilidade para a reparação de tais lacunas de longas datas.

Martins, Carvalhais e Drumond (2007) falaram de ultrapassar a clínica, do vínculo com questões sociais, da interação da Odontologia com as ciências humanas, de uma Odontologia centrada na promoção de saúde, requerendo a integração em equipe, bem como associada à Bioética e ao mundo virtual com reflexos no ensino odontológico, entre outras dimensões.

Promover saúde não seria bem distinto de tratar? Como ocorrer uma superação do paradigma tradicional nas instituições de ensino e formação de dentistas a favor de outros modelos de atendimento e relacionamento de odontólogos com a clientela nas práticas privadas e no serviço público?

A Análise Institucional do Discurso, a nosso ver, poderia ser um dos modos de facilitar a discussão sobre as práticas profissionais e as relações de dentistas com pacientes e acompanhantes nas instituições de ensino e formação de Odontologia, 
forma essa distinta das aulas de Psicologia Geral ou Psicologia aplicada à Odontologia, que promovem a migração e aplicação dos conhecimentos de uma instituição, Psicologia/Psicanálise, por outra, no caso, a Odontologia.

Aliás, os contatos da Psicologia e da Psicanálise com a Odontologia por meio da Análise Institucional do Discurso não se moldam à aplicação dos discursos psi sobre a oralidade, ou outros, no terreno da Odontologia, conforme psicanalistas clássicos, por exemplo, Aberastury (1992 e 1996), e nós outrora (2002a) fizemos. As relações entre o campo psicológico e a Odontologia, bem como entre os dentistas e sua clientela, podem ser repensadas para além da exportação de teorias da Psicologia e Psicanálise ou de sua aplicabilidade, superando o que nos pareceu comum nos interstícios desse terreno epistêmico. Falarmos de Psico-odontologia ou Odontopsicologia, por sua vez, posiciona, segundo nosso entendimento, qual área do conhecimento teria mais força na produção do objeto e método de trabalho de tal terreno interinstitucional, apresentando-se nominalmente na frente.

Precisamos pensar em relações entre Psicologia, Psicanálise e Odontologia que não estão construídas a priori, o que exige esforços de muitos!

Nossos leitores, neste momento, podem achar que estamos sendo otimistas demais, ou ingênuos, acreditando em um movimento instituinte na Odontologia, facilitado pelo campo das ciências psicológicas. Pois é... não nos privamos da integração do onírico, das utopias no mundo social, mas com os pés bem fincados no chão. Lembremos os caminhos da Antipsiquiatria ou de nossos passos desde a Idade da Pedra. Não nos esqueçamos, portanto, como produtores da História nos vários níveis de nossa existência.

Outro reconhecimento que pode surgir à escuta deste discurso é que temos uma visão de para onde a Odontologia caminhar, o que supostamente entraria em contradição com o que falamos anteriormente de não buscarmos substituir o saber da Odontologia pelo nosso. Paradoxos e irregularidades existem na organização discursiva, o que não são furos em nossa visão, mas sim para o positivismo. Além disso, por sua vez, estamos em uma outra cena de nosso trabalho, não mais na Análise em ato, nem na Análise da Análise em ato, porém na discussão de nosso estudo, em nosso ponto de chegada, desconhecido inicialmente, o que produz para nós outros lugares de enunciação. É legítimo, então, que nos posicionemos como sujeitos que historicizam e filosofam a partir de sua experiência vivida. 
De acordo com Wolf (2002), podemos acenar para a importância do olhar do odontólogo e das forças nas relações na Odontologia. Em nossas digressões sobre a formação, ressaltemos que o lugar do dentista de "dar uma olhadinha" foi reconhecido como um incômodo pelas participantes da pesquisa, um enfraquecimento da posição profissional, tal qual vemos, no nosso meio, quando a prática psicológica é associada a "conversar".

Enfatizemos ainda que a Análise Institucional do Discurso, em vez de ser um conhecimento totalizante, pode propiciar, de forma parcimoniosa, uma ruptura no pensamento nas instituições de Odontologia, entre outras. Desse modo, delineia-se como um dos modos de produzir interfaces entre áreas do conhecimento, em vez de uma relação de dominação entre saberes pelas sobreposições deles mesmos. Foi, aliás, nos limites tênues dessa intenção que realizamos nosso trabalho configurado em discurso.

Trabalhamos com as relações institucionais em grupo sem qualquer transcendência ao que nelas se constrói, sem substancialização ou teoricismo do que é um grupo antes que ele aconteça à moda de dizeres acerca da "mente grupal" comuns até ao tom mais rigoroso de Freud e de muitos freudianos. Conforme Costa (1989), que inspira nossa reflexão, o grupo pode ser pensado como uma instituição social, não tendo uma realidade em si, já pronta, à espera das teorias desveladoras de sua "natureza".

Aliás, preferimos falar, em coerência com a perspectiva guiradiana, que fizemos um trabalho com as relações institucionais discursivas em grupo, diferenciando a Análise Institucional do Discurso em Grupo da Psicologia Grupal, que estuda "o grupo".

Com nosso recorte, e a partir do que (nos) reconhecemos, nossas singularidades metodológicas estão afirmadas: uma análise que articula os conceitos de instituição, discurso e sujeito, bem assentada no plano das entrevistas, aqui repensada em um trabalho em grupo. Análise esta que tem em seu crivo noções como as de transferência institucional, polifonia discursiva, cenografia, sujeito dobradiça e com base na qual pensamos na linguagem como um modo de ação, uma instituição, não apenas um veículo de transmissão de informações. A realidade é compreendida, dessa forma, no discurso, não fora ou para além dele.

Com as marcas do pensamento foucaultiano, as relações de poder, por outro lado, podem ser reconhecidas na heterogeneidade de suas produções, não a partir 
de uma teoria geral do poder. Nossa intervenção foi assim, parafraseando Guirado (1987/2004), porque psicológica, institucional e política.

Falamos de particularidades de uma estratégia de pensamento que se diferencia, pela costura epistemológica, dos trabalhos de Balint (2007), Dellarossa (1979), Pichon-Rivière et al. (1983/2009), entre muitos outros, com os quais nos relacionamos em interlocução teórica na travessia de produção de nosso discurso ou instituição discursiva. Uma difererenciação detalhada da Análise Institucional do Discurso em grupo desses outros modos de pensar sobre os acontecimentos grupais pode ser tema para futuras pesquisas.

Podemos mencionar que nos singularizamos em nosso estudo também de trabalhos psicológicos em grupo existentes na Odontologia, que são raros. Aberastury $(1972,1996)$ comentou sobre grupos com crianças e acompanhantes, no território odontológico, cujo manejo tinha por base uma visão psicanalítica clássica. Emílio-Marchioni (1998) inovou ao pesquisar na Odontologia; fez seu estudo em grupo no âmbito da graduação no tocante ao contato dos alunos com pacientes especiais e uma leitura a partir do enfoque grupal, sendo importante a referência de Pichon-Rivière. Carniel (2001), em sua pesquisa, realizou grupos com pacientes em tratamento por desordens temporomandibulares com um modelo teóricometodológico baseado em Pichon. Gorter, Eijkman e Hoogstraten (2001) e Te Brake et al. (2001) trabalharam com intervenção com odontólogos, mas não só grupal, com fundamentação bem distinta da nossa, cognitivo-comportamental, e/ou acompanhamento de efeitos sobre o Burnout do programa realizado.

Sugerimos que outros trabalhos de intervenção grupal em distintas áreas do saber, bem como análises de atendimentos individuais, interconsultas, supervisões ou orientações, entre vários meios de formação e exercício profissional de psicólogos e/ou psicanalistas, sejam estudados à luz da Análise Institucional do Discurso, pois este recurso do pensar nos possibilita a construção de novos modos de operar no campo psi que reconhecem a realidade no plano discursivo estudado, e não na aplicação teórica do instituído como realidade psíquica no campo da Psicologia e da Psicanálise.

Em diferenciação da visão usual de psiquismo da Psicanálise, a Análise Institucional do Discurso a inova: 
epistemológicos externos ao campo psi mobilizam o lugar psicanalítico [...] (BARRETO; GUIRADO, 2009, p. 150)

Agora, não mais em um lugar discursivo analítico da Análise em ato, estrategicamente de forma reflexiva na primeira pessoa do plural, ressaltando as condições institucionais de produção do discurso, eu finalizo, como sujeitodobradiça, na primeira pessoa do singular as letras do meu trabalho acadêmico de doutorado.

Minha presença se constituiu, na instituição deste estudo/análise, subjetivamente do início ao fim, como pessoa, analista, pesquisador e autor em vínculo com muitos interlocutores, as participantes e as forças produtoras desta pesquisa, ao me lançar nas travessias humanas e prenhes de afeto em discurso.

Por fim, de modo interminável, a instituição discursiva, na rebeldia da linguagem, que movimentou e acredito continuar mobilizando as dentistas deste estudo, encontra-se comigo hoje mais pulsante e viva do que antes:

\section{Insubmisso (re)parto}

Esmagam-se as feridas
excluem-se os mendigos
os trôpegos, os bandidos
os loucos, os poetas...

Pretensa onipotência dos que fazem humano ainda se diz inteiro? pensa-se divisível jamais?

Falam do belo nos vendavais da existência instituições de afeto fugaz que se desmancha...

Destroçam-nos bang bang dos Rios brasileiros em ruas, na Saúde na mídia, trágico circo popular...

Transformam-nos em alegorias fantasmas e fantoches de um mundo novo adictos do sangue em videiras da história ou política acrítica. 
Pisoteiam-nos e as flores

Mas em pó re... parto insubmisso

espanto nas letras de um grito políssono

indizível dizível...

Tal é a arte enigmática

de construir e recriar

com a Palavra

o mundo humano.

Ricardo Azevedo Barreto 


\section{REFERÊNCIAS ${ }^{1}$}

ABERASTURY, A. (Org.). El psicoanalisis de niños y sus aplicaciones. Buenos Aires: Paidós, 1972. 236 p.

Psicanálise da criança - teoria e técnica. Tradução de Ana Lúcia Leite de Campos. Porto Alegre: Artmed, 1992. 287 p.

Abordagens à psicanálise de crianças. Porto Alegre: Artmed, 1996. 200

p.

ABRAHAM, K. Teoria psicanalítica da libido: sobre o caráter e o desenvolvimento da libido. Rio de Janeiro: Imago, 1970. 213 p.

ALVES, E.G.R. Pedaços de mim: o luto vivido por pessoas com deformidade facial adquirida pós-trauma bucomaxilofacial e sua interferência no seu desenvolvimento. 2006. 307 f. Tese (Doutorado em Psicologia) - Instituto de Psicologia, Universidade de São Paulo, São Paulo, 2006.

AMARAL, L.A.; BARRETO, R. A. Psicologia e odontopediatria: entre pedaços e/ou relações? In: CORRÊA, M.S.N.P. (Org.) Odontopediatria na primeira infância. São Paulo: Santos, 1998. p. 9-21.

BALINT, M. O médico, seu paciente e a doença. Tradução de Roberto de Oliveira Musachio. 2. ed. São Paulo: Atheneu, 2007. 291 p.

BARRETO, R.A. A afetividade na Odontologia para bebês: lugares e nuances. 1999. 122 f. Dissertação (Mestrado em Psicologia) - Instituto de Psicologia, Universidade de São Paulo, São Paulo, 1999.

O desenvolvimento humano e suas interfaces com a Odontopediatria. In: CORRÉA, M.S.N.P. (Org.). Sucesso no atendimento odontopediátrico aspectos psicológicos. São Paulo: Santos, 2002a. p. 31-35.

. O lúdico em Odontopediatria: contribuições psicológicas. In: CORRÊA, M.S.N.P. (Org). Sucesso no atendimento odontopediátrico - aspectos psicológicos. São Paulo: Santos, 2002b. p. 319-322.

\footnotetext{
${ }^{1}$ De acordo com a Associação Brasileira de Normas Técnicas. NBR 6023.
} 
Sobre a afetividade na Odontologia para bebês. Psicologia: ciência e profissão, Brasília, v.23, n.1, p. 30-37, 2003.

BARRETO, R.A.; GUIRADO, M. Psicanálise e Odontologia na rebeldia inconsciente. Estudos de Psicanálise, Aracaju, n.32, p. 147-152, 2009.

BLEGER, J. (1980). Temas de psicologia: entrevistas e grupos. Tradução de Rita Maria M. de Moraes. 3. ed. São Paulo: Martins Fontes, 2007. 137 p.

BORGES, C.D., SANTOS, M.A. Aplicações da técnica do grupo focal: fundamentos metodológicos, potencialidades e limites. Revista SPAGESP, Ribeirão Preto, v.6, n.1, p. 74-80, 2005.

BOTAZZO, C. Saúde bucal e cidadania: transitando entre a teoria e a prática. In: PEREIRA, A.C. et. al. Odontologia em saúde coletiva: planejando ações e promovendo saúde. Porto Alegre: Artmed, 2003. p. 17-27.

BRANCO, R.F.G.R. Como ensinar a relação médico-paciente: trabalhando com os grupos Balint. In: A relação com o paciente: teoria, ensino e prática. Rio de Janeiro: Guanabara koogan S.A., 2003. p. 124-130.

BUCHANAN, H.; COULSON, N.S. Accessing dental anxiety online support groups: an exploratory qualitative study of motives and experiences. Patient education and counseling, v.66, n.33, p.263-269, jun. 2007. doi: 10.1016/j.pec.2006.12.011.

CARNIEL, I.C. O acompanhamento psicológico no tratamento das desordens temporomandibulares: uma proposta de grupos operativos com pacientes. 2001. 96 f. Tese (Doutorado) - Faculdade de Filosofia, Ciências e Letras de Ribeirão Preto, Universidade de São Paulo, Ribeirão Preto. 2001.

CARVALHO, R.F. O que se passa neles? O que são? In: BAREMBLITT, G. (Org.). Grupos: teoria e técnica. Rio de Janeiro: Graal, 1986. p. 89-106.

CARVALHO, A.C.P. O ensino e as faculdades de Odontologia. In: ROSENTHAL, E. A Odontologia no Brasil no século XX - história ilustrada. São Paulo: Santos, 2001. p. 47-67. 
CONSELHO REGIONAL DE ODONTOLOGIA DE SERGIPE. Manual de orientação ao cirurgião-dentista. Aracaju: CRO-SE, 2007. 106 p.

CONSELHO FEDERAL DE ODONTOLOGIA. Código de ética odontológica. Rio de Janeiro: CFO, 2006. $25 \mathrm{p}$.

CORAH, N.L.; O'SHEA, R.M.; BISSELL, G.D. The dentist-patient relationship: mutual perceptions and behaviors. Journal of the American Dental Association, Chicago, v. 113, n.2, p. 253-255, 1986.

CORAH, N.L. et al. The dentist-patient relationship: perceived dentist behaviors that reduce patient anxiety and increase satisfaction. Journal of the American Dental Association, Chicago, v.116, n.1, p. 73-76, 1988.

CORRÊA, C.P. O diário de Bruno. Salvador: Macunaíma, 2008. 284 p.

CORRÊA, M.S.N.P. (Org.) Odontopediatria na primeira infância. São Paulo: Santos, 1998. $679 \mathrm{p}$.

Sucesso no atendimento odontopediátrico - aspectos psicológicos. São Paulo: Santos, 2002. 659 p.

CORRÊA, M.S.N.P.; KLATCHOIAN, D.A.; HIRATA, R.A. Estresse psicológico e o cirurgião-dentista (Noções de interesse à prática clínica). In: CORRÊA, M.S.N.P. Sucesso no atendimento odontopediátrico - aspectos psicológicos. São Paulo: Santos, 2002. p. 579-594.

CORREAA, M.S.N.P. et al. A saúde emocional do aluno e do professor da faculdade de Odontologia. In: CORREA, M.S.N.P. Sucesso no atendimento odontopediátrico - aspectos psicológicos. São Paulo: Santos, 2002. p. 627-630.

COSTA JUNIOR, A.L. Psicologia aplicada à Odontopediatria: uma introdução. Estudos e pesquisas em Psicologia, Rio de Janeiro, v.2, n.2, 2002. Disponível em: <http: //www.revispsiuerj.br>. Acesso em: 14 fev. 2008.

COSTA, J.F. Psicanálise e contexto cultural - imaginário psicanalítico, grupos e psicoterapias. Rio de Janeiro: Campus, 1989. 175 p. 
DELLAROSSA, A. Grupos de reflexión. Entrenamiento institucional de coordinadores y terapeutas de grupos. Buenos Aires: Paidós, 1979. 172 p.

DIAS, A.A. Saúde bucal coletiva e legislação à luz do programa Saúde da Família. In: DIAS, A.A. et. al. Saúde bucal coletiva: metodologia de trabalho e práticas. São Paulo: Santos, 2006. p. 1-20.

EMÍLIO-MARCHIONI, S.A. Galeria de espelhos: os vínculos no atendimento a pacientes especiais em uma clínica-escola de Odontologia. 1998. 184 f. Dissertação (Mestrado em Psicologia) - Universidade Mackenzie, São Paulo, 1998.

A formação do vínculo no atendimento odontológico. In: SEGER, L. Psicologia e odontologia: uma abordagem integradora. 4. ed. São Paulo: Santos, 2002a. p. 31-42.

A dinâmica familiar no atendimento odontológico. In: SEGER, L. Psicologia e Odontologia: uma abordagem integradora. 4. ed. São Paulo: Santos, 2002b. p. 101-112.

FERNANDES, W.J. Interpretações e outras intervenções. In: FERNANDES, W.J.; SVARTMAN, B.; FERNANDES, B.S. Grupos e configurações vinculares. Porto Alegre: Artmed, 2003a. p. 177-182.

FERNANDES, W.J. Grupos operativos. In: FERNANDES, W.J.; SVARTMAN, B.; FERNANDES, B.S. Grupos e configurações vinculares. Porto Alegre: Artmed, 2003b. p. 195-203.

FERNANDES, W.J. Grupos de reflexão e grupos de discussão. In: FERNANDES, W.J.; SVARTMAN, B.; FERNANDES, B.S. Grupos e configurações vinculares. Porto Alegre: Artmed, 2003c. p. 205-214.

FERREIRA, R.A. Odontologia: essencial para a qualidade de vida. Revista da Associação Paulista de Cirurgiões Dentistas, São Paulo, v.51, n.6, p. 514-521, 1997.

FIGLIOLI, M.D. A prática odontológica da pré-história até o final do século XX. In: ROSENTHAL, E. A Odontologia no Brasil no século XX - história ilustrada. São Paulo: Santos, 2001. p. 5-29. 
FIGUEIREDO, B.G. et. al. Odontologia ao longo do século XX. In: STARLING, H.M.M. et al. (Org.). Odontologia: história restaurada. Belo Horizonte: UFMG, 2007. p. 159-191.

FOUCAULT, M. (1970) A ordem do discurso. 18. ed. São Paulo: Loyola, 2009. 79 p.

. (1979). Microfísica do poder. Tradução de Roberto Machado. 24. ed. São Paulo: Graal, 2007. 295 p.

. (1984). A ética do cuidado de si como prática da liberdade. In: BARROS DA MOTA, M. (Org.). Ética, sexualidade e política. 18. ed. Rio de Janeiro: Forense Universitária, 2006 p. 264-287.

FREUD, S. (1905). Três ensaios sobre a teoria da sexualidade. In: Edição standard brasileira das obras psicológicas completas de Sigmund Freud. Rio de Janeiro: Imago, 1980. v. 7.

. (1913) Totem e Tabu. In: Edição standard brasileira das obras psicológicas completas de Sigmund Freud. Rio de Janeiro: Imago, 1980. v. 13.

(1921). Psicologia de grupo e a análise do ego. In: Edição standart brasileira das obras psicológicas completas de Sigmund Freud. Rio de Janeiro: Imago, 1980. v. 18.

. (1930). O mal-estar na civilização. In: Edição standart brasileira das obras psicológicas completas de Sigmund Freud. Rio de Janeiro: Imago, 1980. v. 21.

(1939). Moisés e o monoteísmo. In: Edição standart brasileira das obras psicológicas completas de Sigmund Freud. Rio de Janeiro: Imago, 1980. v. 23.

FURTADO, J.F. Dos dentes e seus tratamentos. A história da Odontologia no Brasil no período colonial. In: STARLING, H.M.M. et. al. (Org.). Odontologia: história restaurada. Belo Horizonte: UFMG, 2007. p. 21-60.

GALLI, V.L. Mitos e estereótipos na ação profissional em Psicologia e Odontologia. In: SEGER, L. (Org.). Psicologia e Odontologia: uma abordagem integradora. 4. ed. São Paulo: Santos, 2002a. p. 9-30. 
GALLI, V.L. A subjetividade na relação profissional-paciente. In: SEGER, L. (Org.). Psicologia e odontologia: uma abordagem integradora. 4. ed. São Paulo: Santos, 2002b. p. 43-55.

GALVÃO, L.F.; SERRANO, C.E.G. Análise de discurso, leitura institucional: um método. In: GUIRADO, M.; LERNER, R. (Org.). Psicologia, pesquisa e clínica: por uma análise institucional do discurso. São Paulo: Annablume/Fapesp, 2007. p. 2135.

GIGLIO, E.M.; GUEDES-PINTO, A.C.; DUARTE, L.M.A. Princípios de Psicologia e sua relação com a Odontopediatria. In: GUEDES-PINTO, A.C. Odontopediatria. 6. ed. São Paulo: Santos, 1997. p. 131-145.

GIL, I.A. Proposição de reformulações no ensino de psicologia aplicada à Odontologia a partir da análise de relatos verbais de alunos de Odontologia. 1988. 117 f. Dissertação (Mestrado em Educação Especial) - Universidade Federal de São Carlos, São Carlos, 1988.

GIRON, M.C.C. Fundamentos psicológicos da prática odontológica. Porto Alegre: D.C. Luzzato, 1988. 144 p.

GORTER, R.C.; EIJKMAN, M.A.J.; HOOGSTRATEN, J.A. A career counseling program for dentists: effects on burnout. Patient Education and Counseling, v. 43, n.1, p. 23-30, apr. 2001. doi: 10.1016/50738-3991(00)00141-5.

GUILHON ALBUQUERQUE, J.A. Instituição e poder: a análise concreta das relações de poder nas instituições. 2. ed. Rio de Janeiro: Graal, 1986. 163 p.

GUIRADO, M. (1986). Instituições e relações afetivas: o vínculo com abandono. Edição revista e ampliada. São Paulo: Casa do Psicólogo, 2004. 254 p.

. (1987). Psicologia institucional. 2. ed. revista e ampliada. São Paulo: EPU, 2004. $133 \mathrm{p}$.

. (1995). Psicanálise e análise do discurso: matrizes institucionais do sujeito psíquico. São Paulo: EPU, 2006. 134 p. 
A clínica psicanalítica na sombra do discurso: diálogos com aulas de Dominique Maingueneau. São Paulo: Casa do Psicólogo, 2000. 132 p.

. O caso do psicodiagnóstico: um estudo institucional. Psicologia USP, São Paulo, v. 16, n. 4, p. 11-32, 2005.

. Prefácio. In: GUIRADO, M.; LERNER, R. (Org.). Psicologia, pesquisa e clínica: por uma análise institucional do discurso. São Paulo: Annablume/Fapesp, 2007. p. 9-19.

GUIRADO, M.; LERNER, R. (Org.). Psicologia, pesquisa e clínica: por uma análise institucional do discurso. São Paulo: Annablume/Fapesp, 2007. 267 p.

GUIRADO, M. Análise institucional do discurso como analítica da subjetividade. 2009. 316 f. Tese (Livre Docência) - Instituto de Psicologia, Universidade de São Paulo, São Paulo, 2009.

HIRATA, R.A. Paradigmas, transdisciplinaridade e a necessidade da Odontopsicologia. JOPE - Jornal Brasileiro de Odontopsicologia e Odontologia para pacientes especiais, Curitiba, v.1, n.4, p.346-350, 2003.

KLATCHOIAN, D. A relação dentista-criança na clínica odontopediátrica. 1992. 232 f. Dissertação (Mestrado em Psicologia) - Faculdade de Psicologia, Pontifícia Universidade Católica de São Paulo, São Paulo, 1992.

Psicologia odontopediátrica. São Paulo: Sarvier, 1993. 89 p.

KRISTEVA, J. O gênio feminino: a vida, a loucura, as palavras. Rio de Janeiro: Rocco, 2002. 306 p.

MACEDO, P.C.M.; NOGUEIRA-MARTINS, M.C.F.; NOGUEIRA-MARTINS, L.A. Técnicas de intervenção psicológica para humanização das equipes de saúde: grupos Balint e grupos de reflexão sobre a tarefa assistencial. In: KNOBEL, E. (Org.). Psicologia e humanização: assistência aos pacientes graves. São Paulo: Atheneu, 2008. p. 325-341.

MACHADO, R. Por uma genealogia do poder. In: FOUCAULT, M. (1979). Microfísica do Poder. Tradução de Roberto Machado. 24. ed. Rio de Janeiro: Graal, 2007. p. vii-xxiii. 
MAINGUENEAU, D. Novas tendências em análise do discurso. Tradução de Freda Indursky. 3. ed. Campinas: Pontes, 1997. 198 p.

MARTINS, L.H.P.M.; CARVALHAIS, H.P.M.; DRUMOND, M.M. O despertar do século XXI: a humanização das tecnologias. In: STARLING, H.M.M. et. al. (Org.). Odontologia: história restaurada. Belo Horizonte: UFMG, 2007. p. 193-201.

MELLO FILHO, J. Histórico e evolução da psicoterapia de grupo. In: (Org.). Grupo e corpo: psicoterapia de grupo com pacientes somáticos. São Paulo: Casa do Psicólogo, 2007a. p. 33-64.

. Grupos de reflexão: de Balint a Luchina. In: (Org.). Grupo e corpo: psicoterapia de grupo com pacientes somáticos. São Paulo: Casa do Psicólogo, 2007b. p. 99-111.

MENG, H. Psychologie in der Zahnärztlichen Praxis. Bem: Verlag Hans Huber, 1952. $178 \mathrm{p}$.

MORAES, A.B.A.; PESSOTTI, I. A psicologia e a relação cirurgião dentista-paciente. In: PAIVA, J.G.; ANTONIAZI, J.H. Endodontia - bases para a prática clínica. Porto Alegre: Artes Médicas, 1991. p. 237-250.

MUNIZ, J.R.; CHAZAN, L.F. Ensino de Psicologia Médica. In: MELLO FILHO, J. Psicossomática hoje. Porto Alegre: Artes Médicas Sul, 1992. p. 37-44.

NOGUEIRA-MARTINS, L.A. Saúde mental dos profissionais de saúde. In: BOTEGA, N.J. (Org.). Prática psiquiátrica no hospital geral: interconsulta e emergência. Porto Alegre: Artmed, 2002. p.130-144.

ORTIZ, M.C.M. Voluntariado em hospitais: uma análise institucional da subjetividade. 2007. 222 f. Tese (Doutorado em Psicologia) - Instituto de Psicologia, Universidade de São Paulo, São Paulo, 2007.

OSÓRIO, L.C. Psicologia grupal: uma nova disciplina para o advento de uma era. Porto Alegre: Artmed, 2003a. 176 p.

OSÓRIO, L.C. Entendendo e atendendo sistemas humanos. In: FERNANDES, W.J.; SVARTMAN, B.; FERNANDES, B.S. Grupos e configurações vinculares. Porto Alegre: Artmed, 2003b. p. 57-62. 
PAGÉS, C.; ÁVILA, L.A. Visão freudiana dos grupos: da horda ao vínculo. In: FERNANDES, W.J.; SVARTMAN. B.; FERNANDES, B. S. Grupos e configurações vinculares. Porto Alegre: Artmed, 2003. p. 75-85.

PEDROSA, M.A.L. Pesquisa sobre grupos Balint com doutorandos e residentes de Medicina. 1986. 85 f. Dissertação (Mestrado em Psicologia) - Instituto de Psicologia, Universidade de São Paulo, São Paulo, 1986.

PEÑARANDA H., P.M. Psicología odontológica: interdisciplinaridad entre la psicología y la odontología. Caracas: Universidad Central de Venezuela/Ediciones de la Biblioteca, 2000. $180 \mathrm{p}$.

PICHON-RIVIÈRE, E. et al. (1983). Técnica dos grupos operativos. In: PICHONRIVIĖRE, E. O processo grupal. Tradução de Marco Aurélio Fernandes Velloso e Maria Stela Gonçalves. 8. ed. São Paulo: WMF Martins Fontes, 2009. p. 121-137.

PIMENTEL, D. O sonho do jaleco branco: saúde mental dos profissionais de saúde. Aracaju: editora da UFS, 2005. 226 p.

PINTO, V.G. Saúde bucal coletiva. 5. ed. São Paulo: Santos, 2008. 384 p.

PISANI, R. A. Elementos de análise de grupo: os grupos pequenos e intermediários. Tradução de Sérgio Marcos V. Trunci. São Paulo: Casa do Psicólogo/Sociedade Brasileira de Psicanálise de São Paulo, 2005. 179 p.

PRADO, M.M.; FREITAS, A.F.; RIBEIRO-ROTTA, R.F. A relação cirurgião-dentistapaciente: associando o "ser" ao fazer. In: BRANCO, R.F.G.Y.R. A relação com o paciente: teoria, ensino e prática. Rio de Janeiro: Guanabara, 2003. p. 270-279.

RIBEIRO, C.R. Sujeito-dobradiça: metáfora da subjetividade, metonímia institucional. In: GUIRADO, M.; LERNER, R. (Org.) Psicologia, pesquisa e clínica: por uma análise institucional do discurso. São Paulo: Annablume/Fapesp, 2007. p. 245-262.

RING, M.E. História da Odontologia. Tradução de Fernando Gomes do Nascimento. São Paulo: Manole Ltda, 1998. 318 p.

RONCALLI, A.G. O desenvolvimento das políticas públicas de saúde no Brasil e a construção do Sistema Único de Saúde. In: PEREIRA, A.C. Odontologia em saúde 
coletiva: planejando ações e promovendo saúde. Porto alegre: Artmed, 2003. p. 2849.

SAIMOVICI, E. Imagem del odontopediatra y del tratamento odontológico em niños. In: ABERASTURY, A. El psicoanálisis de niños y sus aplicaciones. Buenos Aires: Paidós, 1972. p. 104-116.

SAIMOVICI, E.; SIMOVICI, H.C.K. Significado de la denticion y de los dientes em la obra de S. Freud, K. Abraham, S. Ferenczi y M. Klein. In: ABERASTURY, A. EI psicoanálisis de niños y sus aplicaciones. Buenos Aires: Paidós, 1972. p.163191.

SEGER, L. Psicologia e odontologia: uma abordagem integradora. 4. ed. São Paulo: Santos, 2002. 448 p.

TE BRAKE, J.H.M. et al. Burnout intervention among Dutch dentists: long term effects. European Journal of Oral Sciences, v. 109, n.6, p. 380-387, dec. 2001. doi: 10.1034/j.1600-0722.2001.00086.x.

VIEIRA, C.M.A.M. A construção de um lugar para a psicologia em hospitais de Sergipe. 2006. 164 f. Dissertação (Mestrado em Psicologia Social) - Pontifícia Universidade Católica de São Paulo, São Paulo, 2006.

WALTER, L.R.F.; FERREIRA, A.; ISSAO, M. Odontologia para o bebê. Porto Alegre: Artes Médicas, 1996. 246 p.

WERNECK, M.A.F.; FERREIRA, R.C. Tecnologia e saúde bucal: desafios da incorporação tecnológica. In: PINTO, V.G. Saúde bucal coletiva. 5. ed. São Paulo: Santos, 2008. p. 343-355

WEYNE, S.C.; HARARI, S.G. Cariologia: implicações e aplicações clínicas. In: BARATIERI, L.N. et al. Odontologia restauradora: fundamentos e possibilidades. São Paulo: Santos, 2006. p. 3-29.

WOLF, S. Psicologia no consultório odontológico. São Paulo: Arte \& Ciência, 2002. $174 \mathrm{p}$.

WYNBRANDT, J. The excruciating history of Dentistry. New York: St. Martin's Press, 1998. $248 \mathrm{p}$. 
ZIMERMAN, D. E. Fundamentos básicos dos grupoterapias. 2. ed. Porto Alegre: Artmed, 2000. 244 p. 
APÊNDICE 


\section{TERMO DE CONSENTIMENTO LIVRE E ESCLARECIDO}

Título do projeto: Intervenção psicológica em instituição da Odontologia através de grupo de escuta analítica com alunos de pós-graduação

$\mathrm{Eu}$, portador da cédula de identidade $\mathrm{n}^{0}$ residente à

telefone:

declaro estar consciente de minha participação no projeto de pesquisa de doutorado supramencionado, do pesquisador Ricardo Azevedo Barreto, sob orientação da profa Dra. Marlene Guirado, pelo programa de Pós-graduação do Instituto de Psicologia da Universidade de São Paulo.

Ao assinar este termo de consentimento livre e esclarecido, tenho consciência de que:

- Este estudo é uma pesquisa-intervenção através de grupo de escuta com alunos de pósgraduação em instituição da Odontologia;

- O objetivo da investigação é pesquisar a mobilização no posicionamento profissional e acompanhar as possíveis transformações nos vínculos com pacientes e acompanhantes por meio da Análise Institucional do Discurso durante seis encontros de aproximadamente 1 hora e meia de duração com um grupo de odontólogos-participantes;

- Os discursos do grupo de escuta serão gravados (áudio) para fins analíticos e esses registros ficarão guardados com o pesquisador em seu local de trabalho (consultório) ao término da pesquisa;

- Os resultados obtidos serão utilizados para se chegar aos objetivos desta pesquisa de doutorado e publicação posterior, contextualizada cientificamente;

- Os procedimentos adotados não trazem riscos aos participantes, bem como será mantido o sigilo quanto à identidade das pessoas do estudo;

- Concordo que foram transmitidas as devidas informações para decidir com consciência a respeito de minha participação neste estudo e sei que poderei, no curso desta pesquisa, obter informações, mudar ou excluir dados ou interromper a minha participação;

- Tenho a liberdade de entrar em contato com o pesquisador Ricardo Azevedo Barreto, se desejar falar a respeito do estudo, pelo telefone: (79)9978-8109;

- O termo de consentimento livre e esclarecido possui duas vias: uma para o pesquisador e outra para o participante da pesquisa;

- Reafirmo meu interesse de participar da pesquisa com o intuito de contribuir para o avanço científico.

Aracaju, de de 2008.

Assinaturas: (participante) (pesquisador) (orientadora) 